\title{
BURGAGE TENURE IN MEDIAEVAL ENGLAND HEMMEON
}




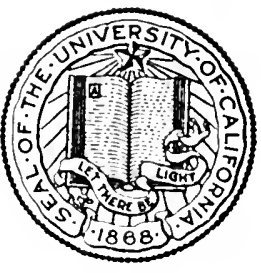

THE LIBRARY

OF

THE UNIVERSITY

OF CALIFORNIA

RIVERSIDE 

Digitized by the Internet Archive in 2007 with funding from Microsoft Corporation 


\section{HARVARD HISTORICAL STUDIES}

\section{PUBLISHED UNDER THE DIRECTION OF}

THE DEPARTMENT OF HISTORY

FROM THE INCOME OF

THE HENRY WARREN TORREY FUND

VOLUME XX 


\section{HARVARD HISTORICAL STUDIES}

I. The Suppression of the African Slave-Trade to the United States of America, $1638-1870$. By W. E. B. DuBois, Ph.D., Editor of "The Crisis." 8vo.

$\$ 1.50$ net.

II. The Contest over the Ratification of the Federal Constitution in Massachusetts. By S. B. Harding, Ph.D., P'rofessor of Furopean History in Indiana University. 8vo.

$\$ 1.25$ net.

III. A Critical Study of Nullification in South Carolina. By D) F. Houst on, A.M., LL.D., Secretary of Agriculture. 8vo. \$1.25 net.

IV. Nominations for Elective Office in the United States. By Frederick IV. Dallinger, A.M., late Member of the Massachusetts Senate. 8vo.

\$r.50 net

V. A Bibliography of British Municipal History. Including Gilds and Parliamentary Representation. By Charles Gross, Ph.D., late Gurney Professor of History and Political Science in Ilarvard University. 8vo.

$\$ 2.50$ net.

VI. The Liberty and Free Soil Parties in the Northwest. liy Theodore Clarke Smith, Ph.D., Professor of History in Williams College. 8vo.

$\$ 1.75$ net.

VII. The Provincial Governor in the English Colonies of North America. By Evarts Boutell Greene, Ph.D., Proicssor of History in the University of Illinois. 8vo.

\$1.50 net.

VIII. The County Palatine of Durham. A Study in Constitutional Ilistory. By (i. T. Lapsley, Ph. D., Fellow of 'Trinity College, Cambridge. 8vo.

$\$ 2.00$ net.

IX. The Anglican Episcopate and the American Colonies. By Arthur Lyon Cross, Ph.D. I'rofessor of European Ilistory in the University of Michigan. 8vo. \$2.50 net.

$x$. The Administration of the American Revolutionary Army. By Louis Clinton Flatch, ['h.I). 8vo.

$\$ 1.50$ net.
X1. The Civil Service and the Patronage. By Carl Russell Fish, Ph.D., Professor of American History in the University of $\mathrm{Wi}$ isconsin. 8vo. $\$ 2.00$ net.

XII. The Development of Freedom of the Press in Massachusetts. By C. A. Duniway, Ph.D., President of the University of Wyoming. 8vo.

$\$ 1.50$ net.

XIII. The Scigniorial System in Canacla. By W. B. Munro, Ph.I., LL.D., Professor of Municipal Government in Harvarel University. 8vo.

$\$ 2.00$ net.

XIV. The Frankpledge System. By William Alfred Morris, Ph.D., Assistant Professor of English History in the University of California. 8vo.

\$1.50 net.

XV. The Public Life of Joseph Dudley. By Everett Kimball, Ph.D., Associate Professor of History in Smith College. 8vo.

$\$ 2.00$ net.

XV1. Mémoire de Marie Caroline, Reine de Naples. Edited by Rohert Matteson Johnston, A.M., Assistant Professor of Modern History in Harvard University. 8 vo.

$\$ 2.00$ net.

XVll. The Barrington-Bernard Correspondence. Edited by Edward Channing, Ph.D. MlcLean Professor of Ancient and Morlern History in Harvard University. 8 vo.

$\$ 2.00$ net.

XVIII. The Government of the Ottoman Empire in the Time of Suleiman the Magnificent. By Albert Howe Lybyer, Ph.D., Associate Prolessor of History in the University of Illinois. 8vo. $\$ 2.00$ net.

XIX. The Granger Movement. By S. J. Buck, Research Associate in 11 istory in the University of Illinois. 8vo. \$2.00 net

XX. Burgage Tenure in Mediaeval Fngland. By Morley de Wolf Hemmeon, Pl..D., sometime Austin Teaching Fellow in ILarvard University.

\section{HARVARD UNIVERSITY PRESS}

$$
\text { CAMBRIDGE, MASS., U.S.A. }
$$




\title{
BURGAGE TENURE \\ IN MEDIAEVAL ENGLAND
}

\author{
BY \\ MORLEY DE WOLF HEMMEON, Ph.D. \\ SOMETIME AUSTIN TEACHING FELLOW IN HARVARD UNIVERSITY
}

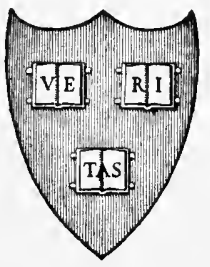

CAMBRIDGE

HARVARD UNIVERSITY PRESS

LONDON: HUMPHREY MILFORD

Oxpord University Press

1914 


$$
\text { Lix } 5-1
$$

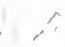

COPYRIGHT, I9I4

BY HARVARD UNIVERSITY 


\section{PREFACE}

THE following monograph was first prepared under the guidance and inspiration of the late Professor Charles Gross and was accepted in partial fulfilment of the requirements for the degree of Doctor of Philosophy in Harvard University in 1908. It was also awarded the Toppan Prize in the same year. Summaries of many of its conclusions were printed in the Law Quarterly Review, July and October, I910, and January, I9rı; but the present work contains much which did not appear there or in the essay as first submitted for the Doctorate. For careful revision of the manuscript and proof, for the preparation of the index, and for verification of matters of detail, the Department of History and the writer desire to express their sincere gratitude to $\mathrm{Mr}$. G. W. Robinson, Secretary of the Graduate School of Arts and Sciences, to whom, in the absence of Dr. Hemmeon, these matters have been entrusted. 



\section{CONTENTS}

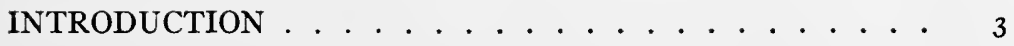

\section{CHAPTER I}

THE INCIDENTS OF BURGAGE TENURE

The Three Aids: Ransom, Knighting, Marrying. . . . . . . II

MARRIAGE ................... I I2

WARDSHIP . . . . . . . . . . . . . . I5

RELIEF . . . . . . . . . . . . . . . . . . . I8

HERIOT . . . . . . . . . . . . . . . . . 22

ESCHEAT . . . . . . . . . . . . . . . . . . . . . . 24

FORFEITURE . . . . . . . . . . . . . . . . . 33

Fealty . . . . . . . . . . . . . . . . . . 45

HoMAgE . . . . . . . . . . . . . . . . . . 49

Military Service ............... 5 I

Retrait FÉOdAL . . . . . . . . . . . . . . 52

Alienation Fees . . . . . . . . . . . . . . . . 54

INPENNY AND OUTPENNY . . . . . . . . . . . . . . . . . . 57

SUIT of COURT . . . . . . . . . . . . . . . $5_{58}$

SumMARY . . . . . . . . . . . . . . . . . 59

\section{CHAPTER II}

BURGAGE RENTS

LANdgable ANd Hawgable . . . . . . . . . . . 62

List of LANDGABleS . . . . . . . . . . . . . . . . 67

Rents and Sales of Messuages . . . . . . . . . . 80

The Nature of the Burgage . . . . . . . . . . . 92

Foreign Tenures within the Borough Bounds ...... IO2

\section{CHAPTER III}

\section{MOBILITY}

DIVISIBILITY . . . . . . . . . . . . . . I08

FREE SAlE . . . . . . . . . . . . . . . . . IIO

ReSTRICTED SAlE . . . . . . . . . . . . . . . II4

INPENNY AND OUTPENNY . . . . . . . . . . . . I 27 


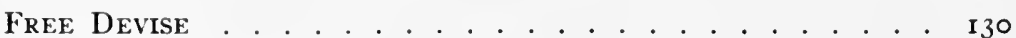

Restricted Devise. . . . . . . . . . . . . I35

The Rights of the Femme Covert . . . . . . . . . . . I44

Mortgage . . . . . . . . . . . . . . $\mathrm{I}_{4} 6$

Accumulation of Burgages . . . . . . . . . . $\mathrm{r}_{4} 8$

\section{CHAPTER IV \\ ACCOMPANIMENTS AND COMPARISONS}

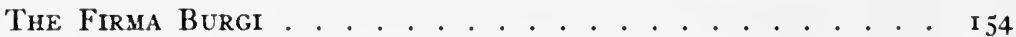
Burgage Tenure in Domesday . . . . . . . . . . I 58 English Burgage Tenure and the Laws of Breteuil . . . 166 Urban Tenure in Normandy, the Netherlands, and Germany . . 172 Conclusion . . . . . . . . . . . . . . . . . . 183

\section{APPENDIX \\ URBAN TENURE IN GERMANY}

The InCidents of Weichbild . . . . . . . . . . . . . . 193

Ground Rents. . . . . . . . . . . . . . . . . . . . . 199

MOBILITY ................... 20I

BIBLIOGRAPHY . . . . . . . . . . . . . . . . 209

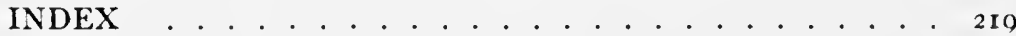




\section{ABBREVIATIONS}

C. A. D. Great Britain. - Public Record Office. A Descriptive Calendar of Ancient Deeds in the Public Record Office.

C. C. R. Calendar of the Charter Rolls Preserved in this Office, I226-I344.

C. I. M. Calendar of Inquisitions post Mortem and other Analogous Documents.

C.P.R. — Patent Rolls, I216-32; Calendar of Patent Rolls, $1232-1485$.

D. B. Domesday-Book.

H. M. C. Royal Commission on Historical Manuscripts.

P. R. O. Public Record Office.

R. C. Record Commission.

R. H. Illingworth, William, editor. Rotuli Hundredorum.

R. S. Rolls Series.

a. anno or annis.

c. or cir. circa.

m. membrane.

t. or temp. tempore or temporibus. 

BURGAGE TENURE IN MEDIAEVAL ENGLAND 



\section{BURGAGE TENURE IN MEDIAEVAL ENGLAND}

\section{INTRODUCTION}

IN the feudal ocean which once rolled over northern and western Europe appeared many islands, relics of a submerged and ante-feudal continent. These islands, some of which were artificial and imitative, were the urban communities. The waves of feudalism might wash their walls; in towns of artificial foundation the spray might be flung into the narrow streets, but there their course was stayed. For the borough, Stadt, or ville had a tenure of its own, the tenure en bourgage of Normandy, the Weichbild of Germany, the Burgage Tenure of England.

In view of its importance as presenting economic and legal conditions of land-holding almost the same as those of modern days, it seems fitting that the tenure of the English mediaeval boroughs should be treated as a subject in itself; and it is perhaps peculiar that no attempt to do so should have heretofore been made. In Germany urban tenure has been, and is yet to some extent, a question which has aroused much controversial discussion by which the literature of origins has been greatly enriched and the sum of human knowledge slightly increased. In Normandy and the Netherlands the tenure has been adequately treated. In England the tenure of land in the boroughs has received some attention from writers on burghal institutions in general, though usually in a way which indicates that, in their opinion, the tenurial side of borough development is hardly as important as the political side. This may be so, yet it seems as if the burgess's influence in shaping the political destiny of anything except his own particular borough is almost a negligible quantity in English mediaeval history, while on the other hand the legal and economic example which he set in the matter of transfer of real property has its results in the modern land law of the realm. Even from the personal side there is reason for 
investigating the tenure, for the close connection between tenure and status was a matter of great importance in the middle ages, a period when the former often determined the latter.

Possibly one reason why writers on English burghal institutions have neglected the tenurial side of borough development is because they have commonly defined burgage tenure when they knew any law, or have had it defined for them when they knew none, as that species of the free or common socage tenure which was peculiar to cities and boroughs. Perhaps Coke should bear as much responsibility as any one for this definition; it is not at all satisfactory. The framers of the Great Charter would not have accepted it; they drew a clear line between holding in socage and holding in burgage. ${ }^{1}$ If one tenure be derived from the other this definition should be reversed, for burgage tenure shows greater age in the survival of at least one archaic custom. ${ }^{2}$ It is more logical as well as nearer in line with fact to regard each as the descendant of a common ancestor, the ante-feudal system of land-holding. But this is the entrance to the jungle of 'origins,' which might be less of a jungle were its so-called explorers to cease for a space from internecine strife.

As feudalism becomes systematized, the burgage and the socage tenure resemble each other less and less. Their resemblance lies in freedom from the feudal incidents. ${ }^{3}$ Where they differ is in mobility; the land in the boroughs can be devised, sold, and divided. It is true that land held in socage might be transferred among the living. It was often sold and divided, but sale and division were attained only by permission. or payment therefor, or by circumventions of the law such as fines and recoveries; ${ }^{4}$ devise the socage tenure never knew. Within the boroughs the leading feature of the land, its mobility, was the leading feature of the land law; there was no need of resorting

1 Magna Carlu, cap. 37 .

2 Military heriot.

${ }^{3}$ Socage tenure, however, was subject to aids and reliefs, and sometimes to wardship.

- True also in the main of land held in feudal tenure even before r29o. The term circumvention is used advisedly and only as an expression of legal means of change. 
to collusion when land was to be sold or divided. The need was the other way; there must be true deliverance made in respect to a sale; there must be publicity, else the sale might be invalid.

The peculiar and distinguishing characteristic, however, of the borough land law, that feature which marked it off so sharply from the land law of the country, was 'freedom of devise.' Says Glanvill, "God alone and not man can make an heir." Yet even in Glanvill's day man could do in many boroughs what only God could do without the borough bounds. Burgage tenure then may be defined as a form of free tenure peculiar to boroughs, where a tenement so held might be alienated by gift, sale, or devise to a degree regulated only by the custom of the borough, unburdened by the incidents of feudalism or villeinage, divisible at pleasure, whose obligations began and ended in the payment of a nominal quit-rent, usually to an elected officer of the borough. ${ }^{1}$

The scanty literature of our subject may be said to begin with Glanvill's law-book, though there is little to be learned therefrom except that its author knew what burgage tenure was. ${ }^{2}$ Bracton gives it a little more attention. To him freedom of devise seemed to be its leading feature; ${ }^{3}$ Littleton saw the same aspect. ${ }^{4}$ The appended quotations show that the writers of these older law books had only a derived interest in the tenure of the boroughs and used its customs for illustration of or comparison with certain custonis of the common land law. The reason for this is that pleas of land in the boroughs were nearly always held in the borough courts, than which few privileges were more highly valued by the English burgesses. As royal judges therefore, these earlier law writers seldom had the tenure brought within their purview; only in case of default of judgment or like ground

1 True only at a very early period of burghal history; at a later period most tenements paid no quit-rents, possibly some had never paid any.

2 Treatise, bk. vii, ch. 1o et pass.

${ }^{3}$ De Legibus, i, p. 164: "si forte legatum fuerit, sicut in burgagiis"; ibid., i, p. 388: "cum laicum feodum legari non possit nisi in rebus specialibus, sicut burgagiis."

"Coke, Commentary upon Littleton, sec. 585: " in ancient boroughs and cities where lands and tenements . . . are devisable by testament by custom and use." 
of appeal was a plea of land in a borough heard in a royal court. ${ }^{1}$

The best modern account of the tenure in English boroughs is that contained in Pollock and Maitland's History of English $L a w,{ }^{2}$ the fullest is that of the introduction to the second volume of Miss Bateson's Borough Customs, a compilation of borough customals edited by that writer for the Selden Society, and arranged, not alway's correctly, under topical headings, as 'Devise,' 'Dower,' etc. ${ }^{3}$ Each of these accounts, however, deals with borough institutions in general; the tenure receives only its proportionate share of treatment. Miss Bateson has also contributed much to the early history of certain created English boroughs by articles in volumes xv and xvi of the English Historical Review, "The Laws of Breteuil." The most valuable treatise in connection with the tenure for a single borough is Maitland's Tounship and Borough, an explanation, illumination, and criticism of tenurial and other conditions in mediaeval Cambridge. Yet when all has been said, not one of these works has the tenure as its primary subject; the tenurial side is only one of many, or is subordinate to the political side, as in Merewether and Stephens's IIistory of the Boroughs and Municipal Corporations of the United Kingdom, a pioneer work which, though not always trustworthy in its conclusions, contains much valuable material, now mostly accessible elsewhere.

For the tenure in France there are at least three important works, two of which, Génestal's La Tenure en Bourgage, relating to Normandy, and Legras's Le Bourgage de Cacn. seem to be the only treatises in any language having the tenure as their primary

1 Of the three Littleton appears to have known most about burgage tenure, yet that most seems very little. Bracton contradicts himself in regard to devise in london. Some moxlern lawyers are little better; see Atcheson, Citse of the Borough of Petersficld, p. 135.

2 Vol. ii, pass.

3 Miss Bateson's preparation for dealing with clauses in customals whose interpretation required legal knowledge was perhaps hardly equal to that which she possessed in other respects. Furthermore, as I shall inclicate, I believe that in her work "The laws of Breteuil" she has pushed somewhat too far an ingenious theory of Xorman origins for English borough customs. See below, pp. 120, 1n. I. 130, n. 2 (customals); $100-172$ (1,aws of Breteuil). 
aim. Of these the latter treats in great detail of the burgage tenure in a single Norman city; the former, notwithstanding its title, really tells less about urban tenure, possibly because its author found less to tell, than such a work as Arnold's Geschichte des Eigentums, which has as its subject the question of urban ownership in general. M. Génestal's work is sometimes needlessly indefinite, its matter is spread out very thin, there is much that seems irrelevant, at least to the tenure, while the author devotes a third of his space to such matters as the origin of urban tenure and so on, subjects better and more ably handled by others, as Des Marez and Keutgen. M. Legras adds nothing to Génestal's account of urban tenure except in respect to transfer of tenements through the seigneur in connection with sales at an early period. The bulk of his work is concerned with the explanation and discussion of rents and procedure. In a less pretentious work by A. Curie Seimbres entitled Essai sur les Bastides, a study of the villes neuves of southern France, various features of the tenure are discussed in connection with other matters.

For the tenure in theLow Countries Des Marez is our authority, with his elaborate and scholarly account, Propriêté Foncière dans les Villes du Moyen-Âge et spécialement en Flandre, in which the city of Ghent gets, as it deserves, the largest share of attention. The tenure in the Netherlandish towns is well described, though this is not the main aim of M. Des Marez's treatise. ${ }^{1}$

It is, however, in Germany that the largest number of works on this subject has been produced, though none with urban tenure as title or primary aim. In I86 I Arnold initiated the discussion of the subject with his Geschichte des Eigentums in den deutschen Städten, his researches being limited mainly to the upper Rhine cities, particularly Basel. His conclusion concerning free urban tenure, that it came from unfree holding and was 'domainial' in its origin, has been disputed with seeming success by various authors. Rosenthal, in his Geschichte des Eigenthums in der Stadt Wirzburg, and especially Keutgen, in his Deutsche Stadtverfassung, join issue with Arnold on the incidence and importance of the

1 For this work see Maitland in English Historical Review, xiv, pp. I37-I4I. 
inherited and heritable lease. That urban tenure was not domainial in its origin but free, and that " nicht Häuser sondern Grundstiicke waren Gegenstand der Erbleihe" 1 are conclusions now generally accepted. Though these conclusions confute Arnold's theory as to the origin, they do not in the least destroy the accuracy of his description of the facts of urban tenure. Dr. Arnold's work is both economic and historical and is chiefly concerned with the Erbleihe, which the author thought gradually passed into Eigenium; his treatment of the tenure as such is incidental but complete.

Keutgen's Untersuchungen über den Ursprung der deutschen Stadtverfassung is a history of all civic institutions, Gericht, Burg, Markt, Rath, and Weide, and deals with the political rather than the tenurial side of burghal development; it gives, however, information about such customs as devise, separation of land and buildings, tenurial heterogeneity, and other features of the tenure. ${ }^{2}$ Dr. Keutgen has since compiled a source book of town charters and Stadirechte, Urkunden zur städtischen Verfassungsgeschichte, of great value as a general source of material for the constitutional study of mediaeval German cities. A particular source of the same sort is Ennen and Eckertz's Quellen zur Geschichte der Stadt Köln, which is only one of the more notable works of this kind. Gobbers's Die Erbleihe und ihr Verhäliniss zum Rentenkauf im mittelalterlichen Köln, ${ }^{3}$ in which the author assigns to leases for life or a term of years the same effect that Arnold credits to the heritable lease, is of considerable importance in the literature of our subject. Dr. Gobbers's conclusions are sharply attacked and apparently confuted by Keutgen. Nearly all these works are polemical, Arnold's Eigentum and Keutgen's Urkunden of course excepted, and all lay much stress on the origin of urban tenure. Des Marez and Génestal argue and discuss at as great length as the German writers. Small space will be given in the pages which follow

' Keutgen, Stadiverfassung, pp. I 2 I-1 22.

2 Sce Professor Maitland's notice of the book in English IIistorical Review, xi, pp. $13-19$.

${ }^{3}$ In Zeitschrift der Savigny-Stifung fïr Rechtsgeschichte, iv, 3 (1 $\left.88_{3}\right)$, pp. 130-21 4. 
to such profitless ploughing of desert sands. With such discussion this essay will have nothing to do except in the conclusion, and then only to the extent of trying to make it clear that the development of feudalism in England was antedated by a system of land-holding in the boroughs which later was called the burgage tenure.

The chief sources for a description of burgage tenure in England fall into two divisions, those which are central in their origin and those which are local. As to the material of the sources no classification can be made. Sources which are local in their origin, as the various borough histories, sometimes draw their material from all quarters, while sources which are central in origin, as the Appendixes to the Reports of the Royal Commission on Historical Manuscripts, are local in their subject-matter. Charters, with few exceptions, are central, they come from the king; borough customals are peculiarly local. A large amount of the source-material for our subject, perhaps a third, comes from the borough charters and customals, together with such brief accounts of rents and connected matters as are given in compilations of town records and in the local histories. With some notable exceptions, which can be found by consulting Gross's Bibliography of British Municipal History, these local histories are only so much dead weight on library shelves; vexatious to the student because of their disorderliness and wordiness; lacking most of what histories should contain; and containing much that histories should omit.

Central sources of great though sometimes unintentional importance are Domesday and the first or royal part of Liber Winton', valuable for an early period of the tenure; the Calendars of Patent and Charter Rolls, of Inquisitions post mortem and ad quod damnum; the Appendixes to the Reports of the Commission on Historical Manuscripts, useful for the purely economic side of the tenure; Rotuli Hundredorum ; Chartae Hiberniae, published by the Irish Record Commission and containing the bulk of the charters to the boroughs of Ireland; and the Placitorum in Domo Capitulari Westmonasteriensi asservatorum Abbreviatio. In addition and supplementary to these are the publications, 
mostly local in scope, by private societies or persons, as the Yorkshire Inquisitions; Hardy's Rotuli Chartarum; Madox's Firma Burgi; and some of the works in the Rolls Series, as Year Books, Munimenta Gildhallae, and Le Domesday de Gippewyz.

In this essay the airn will be a specific description of urban tenure in mediaeval England, avoiding speculation as to its origin, and dealing only with the facts as they are found. The order of treatment will be first the connection between and comparison of the burgage and the feudal tenure as regards the extent to which the former was affected by the incidents and other concomitants of the latter, or by the incidents of villeinage if such should be shown to have existed in boroughs. The purely economic phases of the tenure will next be considered, such as the amounts and incidence of the original or quit-rents, and in addition rents and prices of realty in the boroughs. This will be followed by a discussion of what was, perhaps, the most important feature of the tenure-its modern aspect, with mediaeval modifications, in regard to freedom of sale and of devise. At the close the foregoing material will be drawn on for deductions and conclusions, and in addition the urban tenure in England will be compared with that in parts of France, ir the Netherlands, and in Germany. As it is in the last country that burgage tenure finds its nearest counterpart, and as the tenure there has not been directly treated heretofore, an Appendix will be devoted to a short account of the tenure in the German cities. 


\section{CHAPTER I}

\section{THE INCIDENTS OF BURGAGE TENURE}

THE prevailing land tenure of the middle ages and the normal mediaeval land law of northern and western Europe are feudal. Nowhere is feudalism more wide-spread or more uniform than in England; so all-pervading indeed that even socage tenure must accept the greater number of its incidents. Such being the case, it seems logical and natural, when other than the ruling tenures are treated, to deal with them in accordance with their resemblance to or differences from the classic tenure of mediaeval Europe, whether that treatment concern more the legal, the economic, or the historical side of urban tenure. With this threefold aspect of the subject in view we shall first regard the incidents of burgage tenure as viewed in the light of feudal tenure.

\section{The Three Aids: Ransom, Knighting, Marrying}

The ransom aid may be briefly dismissed. Only once was it required to redeem an English king from captivity, and on this occasion the royal boroughs, where the king was lord, provided their share under the form of a tallage. ${ }^{1}$ There were many small boroughs, however, on baronial and episcopal estates; and while the illegality of private war in England, or the sacredness of his office, lessened the chances of baron or churchman to become a prisoner of war within the realm, such opportunities in foreign war by no means passed neglected. Even in such a case, however, no aid was levied. A tallage, unincidental to the tenure, took its place.

The knighting and marrying aids were unknown, the little baronial borough of Castle Rising excepted. Early in the thirteenth century Hugh of Albini, Earl of Sussex, granted burghal privileges to the townsmen of Castle Rising, and among the said

1 Stubbs, Constitutional History of England (1880), i, p. $5^{64}$. 
'privileges' was this: " if the lord make his eldest son a knight, or his eldest daughter be married, then the burgesses shall give him reasonable help." 1 This, though certainly an aid, is rather an occasion for taking a tallage than a service due as an incident of the tenure; it lies on the burgesses or corporate body rather than on the burgage tenements. ${ }^{2}$

\section{MARRIAGE}

This incident is usually considered along with wardship; and in the feudal tenure the two are, as it were, complementary, one often entailing the other. This could never be the case with burgage tenure, which was free from the marriage incident. Most of the older boroughs, the boroughs by prescription, apparently have never even heard of marriage. Their customals ignore it. The newer or created boroughs, especially those with baronial or episcopal lords, often have this incident mentioned in their charters, but only as an obligation from which their tenure is free.

At Cardiff a burgess "may at his will marry his son or his daughter, without having to seek license from any one," 3 and though the wording of their charters may be different, the same is the case at Preston, ${ }^{4}$ Tewkesbury, ${ }^{5}$ and Castle Rising. ${ }^{6}$ At

1 Parkin, Lynn, p. 205.

2 The customs were declared at a survey made by Sir N. Bacon, J. Hill, R. Buxton, and R. Shephard in ${ }_{15}$ \%9. Hugh of Albini died Earl of Sussex in 27 Henry III. From his name he seems to have been one of the 'Lusignans' and neither an Englishman nor a Norman.

Though Earl Hugh knew little of English burgage tenure, James I knew less. When his daughter, the Winter Queen, was married, he surprised the burgesses of Reading with a demand for an aid. He did not get it.

${ }^{3}$ Matthews, Cardiff Records, i, p. 12. The order here followed in naming the boroughs is as far as possible the chronological order of their charters. The Cardiff charter dates from $1147-8_{3}$, and seems to be a traverse of some existing Norman customa.

4 Fishwick, Preston, P. I6, and Harwick, Preston, p. 260: "if a burgess marry his daughter or granddaughter to any one, he may marry her without the license of any one." The charter dates from aloout I I73, and follows probably the Breteuil custom.

'Bennett. Teukesbury, p. 32 r. Tewkesbury and Cardif had the same customs.

"I'arkin, Lynn, p. 205; the burgesses' "heyres shall marry themselves wheresoever they like." 
Dunwich in I 200 marriage was free to all but widows, who needed 'the counsel of their friends.' 1 In I2I5 this disability was removed. ${ }^{2}$ At Whitby a widow might not marry without the consent of the abbot, who was lord of the borough. ${ }^{3} \quad$ There was no marriage at Cork $^{4}$ or Kilkenny, ${ }^{5}$ but at the latter place a saving clause in the charter prevented one who held by feudal tenure - or socage in some cases - without the borough, and by burgage within, from escaping feudal obligations by pleading burghal freedom. ${ }^{6}$ The Drogheda charter of 1253 has the same clause; ${ }^{7}$ the charters to Limerick ${ }^{8}$ and Wexford show the same condition in respect to the marriage incident. ${ }^{9}$ This limitation on freedom from marriage, though never found in customals and seldom in charters, must be taken for granted unless there is proof that burgesses were freed therefrom, but it is not an incident of burgage tenure and would fall lightly on burgesses proper, who seldom held outside the boroughs. Its efficacy was tested later when outsiders began to acquire burgages.

From direct statement and from implication it is plain that a burgess who was also a holder under military tenure was liable to all the burdens of feudalism, unless they could be avoided by a grant from the lord of the borough or evaded by a special agreement. The former was the case at the Cinque Ports, to whose

1 Hardy, Rotu? $i$ Chartarum, p. 5I. Dunwich was a royal borough. Possibly King John did not think a widow competent to make a second marriage unassisted, but probably the clause was inserted as a measure of protection to semi-orphans.

2 Ibid., p. 2I I. The Dunwich of that day, with its counselled widows, lies under the sea.

3 Atkinson, Whitby, p. $32 \mathrm{I}$.

1 Chartae Hiberniae (Irish Record Com.), pp. 24-25. See also Caulfield, Council Book of Cork, p. xi.

5 Gale, Corporate System of Ireland, app., p. xxiii.

6 The charter grants "etiam eisdem burgensibus matrimonium contrahere sibi et filiis et filiabus suis et viduis sine licentia dominorum suorum, nisi forte firmas forinsecas tenuerint de me in capite extra burgum." Gale, app., p. xxiii: all these charters may be found in Chartae Hiberniae.

7 Gale, Corporate System, app., p. vi.

${ }^{8}$ Lenihan, Limerick, p. 47. The first charter is from Hamo of Valois; the customs are those of Dublin.

9 It must not be overlooked that these so-called Irish boroughs were English in all but name and location, industrial and military garrisons in a foreign land: in most of them an Irishman might not become a burgess. 
barons Edward I granted that " all persons born within the said Cinque Ports" (seven are named: Sandwich is omitted) " although they hold lands without the liberty of the Ports by such a service that their marriages should, by reason of their minority, belong to the king, may nevertheless marry according to the liberty of the Ports . . . saving the right of any other." 1 This saving others' rights, perhaps characteristic of Edward I, refers to the fact that in the royal boroughs there might be many lords in, but not of, the borough, standing as mesne lords between the burgess and the king. ${ }^{2}$ Nearly a century before this King John had given the same privileges to the Bristol burgesses, ${ }^{3}$ and a little later to those of Dublin. ${ }^{4}$ It is almost needless to say that he did not save others' rights, and only fair to say that his action was quite lawful, for he was the lord of the borough. At any rate few burgesses would profit thereby; if a burgess should happen to hold under feudal tenure he might, and sometimes did, avoid its incidents by special agreement. ${ }^{5}$

${ }^{1}$ C. P. R., a. I 298, p. 348 . Twenty years before this Edward had granted to the barons of Deal that they might "have forever this liberty, viz., that neither we or our heirs shall have . . . marriages of their heirs, by reason of their lands which they hold within the Ports . . of which neither we nor our predecessors have had marriage in times past." Chapman, Deal, p. 8. That is, the king grants rights which he never had to those who always harl them. In the Cinque Ports, as in many other boroughs, a minor heir's marriage was regulated by law. The guardian of such persons must obtain the consent of the mayor and jurats to their marriages, otherwise he was liable to a penalty of $£_{100}$. Boys, Sanduich, p. 5 i6; Lyon, Dover, i, p. xlv.

2 This might be the case in baronial and abbatial boroughs also. The king might be a holder between abbot or baron and burgess: he was such at Bury Saint Ellmunds.

3 Seyer, Chaters of Bristol, p. 8, c. I1 88: he granted "quod possint maritare se et filios et filias et viduas sine licentia dominorum suorum" and in addition "quorl nullus dominorum suorum propter forinsecas terras habeat . . donationem filiorum ... filiarum vel viduarum." It has been suggested (Seyer, Memoirs of Bristol, i, p. 513) that this clause was to relieve burgesses who held of other lords than the king from these lords' demands of ' marriage.' The clause, however, does not concern burgesses who hold burgages only, the previous clause is for them. It states that a Bristol burgess may holk under outside tenures and not be subject to ' marriage.'

- Walsh, Dublin, i, p. 48, a. I173: as a rule whateser Bristol has Dublin has.

${ }^{3}$ In r $270 \mathrm{~A}$., claughter of the lord of Wodehall, granted to T., burgess of Newcastle, the town or vill of Swarland with homage and service of various men; T.'s heirs were not to be subject to marriage. C.C. R., ii, pp. I69-1 70. 
It is only natural to expect something in regard to marriage in the charters of some of those humble boroughs which had been vills at a period not long before. Though the fact of burghal freedom precluded marriage yet the new burgesses might rest easier with a guarantee in the charter. Sometimes, though not often, a clause therein renounced the lord's right to marriage, as at Christchurch Twynham ${ }^{1}$ and at Egremont. ${ }^{2}$ Occasionally, and apparently as an afterthought, a customal of an older borough states that there is no marriage, and implies that there never has been any. ${ }^{3}$

\section{WARDSHIP}

'Marriage' is simply unknown to burgage tenure. As to Wardship the case is very different; yet the wardship of the burgage tenure had no connection with the wardship of feudalism. Nor was urban wardship always the same; it varied from borough to borough, and the borough lord had no voice in its working, though sometimes, as at Berwick and Dover, he oversaw its operation. ${ }^{4} \quad$ As in the case of marriage, holding under both the burgage and the feudal tenure sometimes freed burgesses from the wardship of the latter, though not as a matter of course;

1 C. P. R., a. I3 5 , p. 220. Inspeximus of a charter from Baldwin de Redvers, Earl of Devon: " as the said free burgesses have been in the times of his father and himself free from ransom of their sons and daughters "the earl promises that " no ransom . . . shall be extorted from them by him or his . . . bailiffs."

2 Bateson, Borough Customs, ii, p. 85: "non dabit merchet "; merchet, however, is improperly used here, the reference is to childwite. At Tutbury (Mosley, Tuibury, p. 368) "the tenants shall pay no mortmaine" (mainmorte).

At Manchester in 1574 'good orders' were made for marriages by consent of the high steward and the burgesses' jury (Court Leet Records of Manchester, i, p. 262), whatever that may mean.

${ }^{3}$ As at Ipswich: Bacon, Annalls of Ipswiche, p. 34. Why then the grants of freedom from 'marriage' in patents and charters at Bristol, Dublin, and the Cinque Ports? Because the first grants, simply statements of customs, are and are meant to be only vehicles for second grants, freeing outside holders because of their burghal tenurial status.

At Shrewsbury it had at one time cost a maid ros. to get married and a widow, 2os. (D. B., f. $252 \mathrm{a}$ ), but there is no trace of 'marriage' in King John's day. Owen and Blakeway, Shrewsbury, i, p. 86.

- The wardship of a tenement and the wardship of an heir to that tenement are sometimes separated. 
such freedom was the result of a royal grant to a few boroughs, was limited to the person, and did not extend to lands held outside the borough, the lord of such lands retaining them in custody. Bristol, ${ }^{1}$ Dublin, ${ }^{2}$ and possibly the Cinque Ports ${ }^{3}$ had this privilege, which was a saving clause in the burgess's interest, not the lord's, who got only the wardship of his foreign lands but not the custody of the person of the ward or of the ward's tenements in the borough.

A few of the boroughs of Ireland had the same freedom as Dublin in respect to wardship, but modified in such a way that it was probably only a condition designed to prevent military tenants who also held in the borough under its tenure from evading their feudal obligations. ${ }^{4}$ At times wardship was avoided by agreement, as in the case of a Newcastle burgess who held one or more manors in the foreign. ${ }^{5}$ The rule, however, was that a foreign tenure carried its obligations with it, and a burgess who held by a tenure outside a borough was in wardship during minority if that tenure entailed it. ${ }^{6}$

In most of the boroughs wardship of both person and tenements was a private concern except in cases of intestacy. Some cus-

1 Seyer, Brislol Charlers, pp. 8, 9: "nullus dominorum suorum propter forinsecas terras habeat custodiam ... filiorum . . . sed tantum custodiam tenementorum suorum quae sunt de feodo suo, donec aetatem habeant."

2 Walsh, Dublin, i, p. 379 .

${ }^{3}$ Chapman, Deal, p. 8; Lyon, Dover, i, pp. xlii, xlv. There was nothing new in the grant to the Cinque Ports; the king merely renounced "wardship of heirs by reason of lands... within the Ports of which neither we nor our predecessors have had wardship." Cf. a like statement in regard to marriage.

- Gale, Corporate System of Ireland, app., p. xxiii: as at Kilkenny where the liberty of I) ublin is given in regard to wardship ' nisi de me [W. Marshal], sicut praedictum est, extra burgum in capite tenuerint.' At Waterford (C. C.R., i, p. 158, a. 1 232) a burgess's foreign lord had wardship of tenements only.

${ }^{5} C$. C. R., ii, p. I zo: he avoided marriage as well.

- In 1279 , in the course of a suit in the Ilustings with reference to the ownership of messuages in London, a charge was made that the feoffment had been obtained by fraut practised during the ward's minority " while she was in the custody of $R$. in the County of Ievon (where she has other lands), to whom the said custody was demised by Ifenry III" (C. P. R., a. 1279, p. 406). These lands in Devon may have leen held under military tenure, but socage tenure was not always exempt from wardship, as in the case of a "messuage... in Botesford and Hlympton, county Devon, . . . the same . . . held in socage by the sole service of Id. a year of H., a minur in the king's custody" (C. P. R., a. 1294, p. 126). 
tomals however forbad any immediate lord of a tenement, usually called the 'chief lord ' 1 from acting as guardian, as at Ipswich," Dunwich, ${ }^{3}$ and Castle Rising. ${ }^{4}$ Nearly all the borough customals provided for wardship of persons and tenements. At Bury Saint Edmunds at one period the nearest relation was guardian, ${ }^{5}$ at another the mayor and aldermen had wardship of orphans. ${ }^{6}$ At Nottingham, in one case at least, an heir appointed his own guardian; ${ }^{7}$ at Hedon the mayor and coroner took charge of tenements falling to those under age. ${ }^{8}$

At Canterbury the wardship of orphans was given by the 'bailiffs and xii' to the nearest in blood to whom the heritage might not go. ${ }^{9}$ The sam 2 custom obtained at Ipswich, and a guardian was held strictly responsible for waste to an heir's property. ${ }^{10}$ Sandwich, and by implication the rest of the Cinque Ports, had the same custom as Ipswich and Canterbury, and in this case the king seems to have acted as an overseer of the town magistrates, holding them to a strict performance of their duty, intimating that he has been informed that they have been derelict therein, and insisting that the civic authorities not only shall not act as guardians themselves but also shall not allow others so to act who have any possible interest in the minor's heritage. ${ }^{11}$

1 Sometimes capital lord, the one next the actual holder.

${ }^{2}$ Le Domesday de Gippewyz, pp. 89-9o; Bacon, Annalls of Ipswiche, p. 34: " nor shall any suche cheife lord have any . . . ward."

${ }^{3}$ Hardy, Rotuli Chartarum, p. 2 II: no lord shall have 'custodia.'

4 Parkin, Lynn, p. 205: "his kin or next cousin by the mother's side."

5 Arnold, Memorials of St. Edmund's Abbey, i, p. 305: "consuetudo extitit ratione burgi ut proximus consanguineus habeat wardam pueri cum haereditate."

6 Ibid., iii, p. 305; from the unconfirmed charter of 1327 .

7 Stevenson, Records of Nottingham, i, p. $7 \mathrm{r}$.

\& Boyle, Hedon, app., p. Ixix.

${ }^{9}$ H. M. C., Rep., 9, pt. I, p. I7I: this is the law of wardship for the socage tenure in England and (later) of the feudal tenure in Normandy.

10 Bacon, Annalls of I pswiche, p. 27.

11 Boys, Sandwich, pp. 514-516, a. I35r. In consideration of the fact that the king was Edward III, one must understand royal government or some fraction thereof in place of 'king.' The wrongs of orphans could mean little to Edward III, at that time still flushed from Crécy. Perhaps the borough magistrates also felt that victory entailed immunity from legal penalties: the Cinque Ports were Edward III's right hand in his wars with France. The proclamation to the mayor. and jurats is to the effect that the king having heard that orphans have been ill- 
The whole proceeding was probably suggested by Edward I's dealings with the burgesses of Berwick, the mayor and bailiffs of that place being charged with the execution of the part of the charter relating to wards and with a supervision over guardians. ${ }^{1}$ The king was the lord of Berwick and the Cinque Ports, all being royal boroughs, but his assumption of the position of guardianin-chief had nothing feudal about it; the king acted here as head of the state and not as a feudal lord, and the result of this action was, in theory at least, to prevent the making profit of an heir's expectations at the expense of his inheritance. ${ }^{2}$

The age of majority, when wardship ended, varied in different boroughs and even in the same borough at different periods. Very often it was determined not by years but by ability 'to number' (2od.; infrequently I2d.) 'and measure' (a yard or an ell of cloth). The usual age was 12 or 14 ; at a few boroughs it was $2 \mathrm{I} .^{3}$

\section{RELIEF}

From this incident the older and larger boroughs were free in the age of charters and customals, and, using the term in its exact sense of a payment of money from an heir previous to his

treated, it is his command that the mayor and jurats " do in our name and by our authority" appoint guardians, etc. (p. 515) "and our will is that neither the mayor nor jurats ... do have the care and custody of orphans, unless specially appointed by the will of the ancestor and having no possible interest in the inheritance" (p. $5 \mathrm{r} 5$ ). The town magistrates embodied these orders in a resolution and governed themselves accordingly:

${ }^{1}$ Scott, Berwick, PI). 246-247.

2 I'rivate dealing in wardship and marriage seems to have been very common in some of the boroughs, notably Lonclon. See R. R. Sharpe, Cal. of Letters from Mayor, etc., pp. 160-16r, a. $1368-69$. Is a result of such transactions the aid of the royal government was sometimes invoked to prevent fraud, as at Marlborough: C. I. .H., i, p. 227, 53 IIenry 11 I.

3 At Iledon at one date it was 16 , at another it was 21 (Boyle, Hedon, app., p. Ixix); at I pswich 14 , sometimes 12 (Bacon, Annolls of Ipsaciche, pp. 72, 87,02; Le Domesday de (ippeays, p. S8), but this 'age "was proved by " numbering and measuring '; at Yarmouth 21 (Swinden, Yarmouth, 1). 155); at Hereford ability to numler and measure (Johnson, Incient ('ustoms of Ilereford, p. 25); at ('anter-

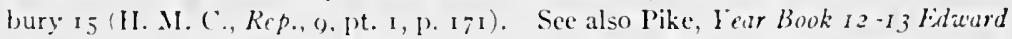
III, 1). 236); Parliumentary Papers, $1 \$_{35}$, xxvi, p. $28_{3} 8$; Chartue, Privilegia, et Immunitates, pp. 80-82, 80; (Gilbert, Colendur of Records of Dublin, i, pp. 225, 329; Plucit. Westmon. Abbr., p. 224, roll 77 ; Mrs. J. R. Green, Toun Life in the Fiftecnth Century (1894), i, p. 200; Bracton, De Legibus, v, p. 177. 
entering on an inherited estate, it seems that most of them, if not all, had always been free. ${ }^{1}$ A few customals and those charters to created boroughs which go into particulars ${ }^{2}$ state the absence of this incident. Such was the case at Ipswich, ${ }^{3}$ Cardiff, ${ }^{4}$ and York with its suburbs. ${ }^{5}$ Relief was unknown in the boroughs of Ireland, whose charters nearly always deny the presence of this incident, as at Rathcool, where the Archbishop of Dublin's charter stated that, as the burgesses had never been accustomed to pay relief, they should always be exempt therefrom. ${ }^{6}$ Relief did not exist at Romney, ${ }^{7}$ or, probably, at any of the Cinque Ports, at Kidderminster, ${ }^{8}$ Tewkesbury, ${ }^{9}$ Barnstaple, ${ }^{10}$ or Hereford, ${ }^{11}$ or, in the later part of our period, at Bury Saint Edmunds. This is the rule in the older boroughs, whose customs usually

1 The citizens of York paid no relief (D.B., i, f. 298a); there is no reason why York should have been exceptional, in the Danelaw at least.

2 Most of these are only more or less perfect copies of the customals of older boroughs.

${ }^{3}$ Bacon, Annalls of I pswiche, p. 34: " nor shall any suche cheife lord have any relief."

4 Matthews, Cardiff Records, i, p. I 2: " no burgess shall give for his burgage an heriot or relief." Ipswich was a borough by prescription, the source of the quotation is the customal; Cardiff was a borough created by charter, embodying probably the customal of some Norman ville. The result is the same.

5 Widdrington, Analccta Eboracensia, p. т21. At Bootham, in an inquestfinding of $1286-90$, the citizens say that "the tenements there . . . are in all things of the same condition and custom as the other tenements of the city, and they pay no relief," a finding consonant with the Domesday record.

${ }^{6}$ Gale, Corporate System, app., p. $\mathrm{x}$ : "quia de burgagiis suis relevia dare non consueverant eis eadem remissimus . . . ita quod de dicto burgagio nunquam de cetero relevium exigatur sicut nec unquam ante tempus nostrum exigi consuevit." Rathcool, Limerick, Waterford, and Cork have the customs of Dublin and Bristol, where there was no relief. The rest of the boroughs of Ireland have the laws of Breteuil, an extinct Norman ville, where relief was likewise unknown.

7 Lyon, Dover, ii, p. 320: " no . . . relief . . . shall be due to no lord of the fee."

8 Burton, Kidderminster, p. 58.

9 Bennett, Tewkesbury, p. $32 \mathrm{I}$.

${ }_{10}$ Chanter and Wainwright, Barnstaple Records, i, p. II3; relief existed among extra-burghal tenants in 1274 , but there is no proof of its presence in the borough.

11 Johnson, Customs of Hereford, p. 25: no ' foreign service.' - In $1_{31} 5$ a holder of a tenement in the city was impleaded because no relief had been paid, the chief lord (another burgess) maintaining that such was the custom. He lost his suit, however, because "nullus sic tenens in liberum burgagium in eadem civitate solebat dare Regi relevium" (Madox, Firma Burgi, p. 257, Herefordia). 
neglect the subject or exclude it by inference in stating the rule for the transfer of inheritance. ${ }^{1}$

There were, however, boroughs, created as a rule, and of small importance in the middle ages, where relief existed. It was probably an incident of the tenure at Leicester, where the term occurs in grants and transfers of tenements within the borough. ${ }^{2}$ Relief was owed at Dartmouth, ${ }^{3}$ Exeter, ${ }^{4}$ and at Denbigh, ${ }^{5}$

1 In the absence of a customal, records of the transfer of tenements often show the absence of this incident. These grants and transfers, however, seem at times to be drawn with intent to deceive, or more probably, the grantors, as is the fashion with the ignorant, fell upon forms of words which meant nothing at all, as far as the users thereof were concerned. For instance in 1352 a widow in King's Lynn, at that time Bishop's Lynn, left by will various rents and a tenement in the borough to her daughter for "the whole term of her life, together with the reliefs . . . of all that tenement" (H. M. C., Rep., I I, app., pt. 3, p. 232). Lynn had the privileges of Oxford as stated in a charter from the bishop of Norwich in 5 John. Charters to episcopal and abbatial boroughs nearly always contain saving clauses; it seemed hard for a bishop or an abbot to be perfectly frank or generous, and the bishop added this: "salvis ipso episcopo . . . et comiti Arundel et hereditates . . . libertates et consuetudines quas ipsi in praedicta villa antiquitus habuerunt" (Parkin, $L y n n$, p. I I 7 ). The customs saved seem to be nomination of the bailiff, collection of rents of assize, court and court leet profits (ibid., p. ${ }_{5} 6$ ). There is no word of relief even when the bishop gave the burgesses his forfeitures, etc., in 1404 . No other record of the transfer of a tenement (ibid., pp. I 8-200) mentions relief. A widow's testimony shall not condemn a whole city.

In 1273-74 another widow, in Dover this time, bequeathed reliefs supposed to arise out of half an acre of land in Charlton Hundred (Statham, Dover Charters, p. II), a small corner of which, however, lay outside the Dover liberties (Samuel Lewis, A Topographical Dictionary of England, 7th ed., 1848, i, p. 55 I). Possibly she was not, but probably she was, bequeathing something that did not exist. It is not likely that the term is equivalent to easements; it would be commoner in that case.

2 Bateson, Records of Leicester, i, p. $38_{2}$ : burgesses sometimes grant rents and reliefs arising out of a tenement to other burgesses. In this case the lord of the borough would be entitled to relief when an original burgage was transferred or if he were chief lord. Henry $I$ released the mayor and community from reliefs (ibid., ii, p. 227). Much faith, however, should not be placed in Silverun, daughter of Robert le Vilen, who gave a release from reliefs and homages in 1250 (ibid., i, P. $\left.3^{8} 3\right)$; the lym and bover widows may have influenced her.

II. M. C., Rep., 5, p. 599 (2 I Fd. I): Gillbert Fitz-Stephen, the lord of the borough, in granting a tenement retained a right to " $2 \mathrm{~s}$. for relief when falling due."

"Bateson, Borough Customs, ii, p. 6r: "if one man holds a burgage of another by service, he may sell it, saving the lord's right, and if he sells it unconditionally, the relief is the lord's." This is on its face only an alienation fee.

5 Williams, Denbigh, p. 307. The charter was given by Henry de Lacy, and 
where it was still paid, it is to be hoped with regularity, in the nineteenth century. ${ }^{1}$ It was payable at Doncaster, apparently only when tenements descended by the law of intestacy, ${ }^{2}$ and at Northampton, where it seems to have been due from those who received tenements by bequest and at the transfer of original messuages; ${ }^{3}$ the amount was probably fixed at one year's rent of the messuage. ${ }^{4}$ This incident is found at Pembroke, ${ }^{5}$ Bideford, ${ }^{6}$ Farnham, ${ }^{7}$ and Portsmouth, where it seems to have been due at the alienation of a tenement as well as at an heir's entrance. $^{8}$ At Reading the corporation took a half-year's rent of a burgage as relief; ${ }^{9}$ at Stockport this incident is found, ${ }^{10}$ at Manchester it was common. ${ }^{11}$

ratified by Edward $I$ in 1290 . No Welshman might be a burgess in Denbigh and the English "heirs and assigns . . of all the burgesses aforenamed " must pay "to us and to our heirs, the first year after the death of their ancestors, for the burgages . . . aforesaid, Id. as relief." A few messuages paid 4 d. a year and one paid $16 \mathrm{~d}$. as rent: in each case relief was the same.

${ }^{1}$ At Denbigh and its contributory borough Ruthin, reliefs of Is. each and usually called heriots, still existed in 1835 . Parliamentary Papers, I835, xxvi, p. 2185.

${ }^{2}$ Hardy, Records of Doncaster, ii, p. I9: it was not a general obligation (ibid., ii, p. 20). In 1506 a record of the fall court leet states that a burgess had left a tenement in Bramwyth to his son by will but had made no disposition of his other tenements. A "relief therefore accrues of $4 \mathrm{~s}$."

${ }^{3}$ Markham, Liber Custumarum, p. 26: if one hold "lond, tenement, or rente" of another "by a litell servise of silver serteyn named" [i.e., a fee-farm or burgage rent], "or bi graunte after the dethe of the tenaunt" [? devise], "relef theroffen shall be geven."

${ }^{4}$ Markham, Liber Custumarum, p. 26. If a tenant held more than one tenement " of only the chefe lorde" ( ? one chief lord) he need pay but one relief "for all tho tenementis."

${ }^{5}$ C.P.R., $a .1378$, p. 107: $12 \mathrm{~d}$.

${ }^{6}$ Watkins, Bideford, p. 13: r 2d. Burgage rents in Bideford were $12 \mathrm{~d}$. or $6 \mathrm{~d}$.

7 Hall, Pipe Roll of the Bishopric of Winchester, a. 1 208-09, p. 38.

${ }^{8}$ East, Records of Portsmouth, pp. 53-55: in 1620 a son and a daughter, who inherit by will, enter and owe relief. The incidence of the obligation seems uncertain; in $1620-45$ there were recorded 6 alienations with relief and 16 without it. Cf. relief at Exeter.

${ }^{9}$ Guilding, Reading Records, iii, p. 55, a. 1631: it was called heriot.

${ }^{10}$ Heginbotham, Stockport, i, p. I63, a. 1622.

${ }^{11}$ Court Leet Records of Manchester, i, p. 204, a. 1579: in one case a relief of 8s. 6d. is coupled with a rent of $8 \mathrm{~s}$. $9 \mathrm{~d}$. These court leet records of the r6th century are rather quaint: in 1585 the leet jury "presentant quod est una equa coloris white grey somethinge fflayebitten etatis septem Annorum sive plus." Ibid., i, p. 253. 


\section{HERIOT}

Closely connected with relief is heriot, here to be used with its strictly burghal meaning, ' some sort of arms,' a military chattel in one sense, though the records sometimes speak of a moneypayment as a heriot (as at Reading) and sometimes of rendering a chattel as relief. Heriot was never used with the villein meaning of 'best chattel,' nor had the lord any voice in its choice; it was a definite thing - a sword, or lance, or bill - to be rendered at a burgess's death. At times money might take its place, and it looks much like the heriot of the law of King Canute.

This incident is never found in any but some small purely agricultural boroughs. Its existence is mentioned only to be denied at Hereford ${ }^{1}$ in ${ }^{2} 28{ }_{1}-82$, when the burgesses were gathering together their customs, not without price, for the men of Haverfordwest, who needed a customal; Newcastle; ${ }^{2}$ Kidderminster $;{ }^{3}$ Tewkesbury $;{ }^{4}$ and a few other boroughs of the middle class. In a still less important class of boroughs heriot was very present. Among them are Stockport, Salford, ${ }^{5}$ and Manchester, ${ }^{6}$ where the terms burgess and heriot seem to have retained a military character and sound, perhaps from the days of the Danish kings, the echo of which is not wholly silent in the sixteenth century. ${ }^{7}$ At Manchester both heriot and relief were

I Johnson, Customs of Hereford, p. 26: no heriot was due "to any one at the death of a citizen dying within the city or suburbs for any of his tenements situate therein."

${ }^{2}$ Brand, Vericustle upon Tyne, ii, p. 130: the customal embodies the usages temp. Henry I. See also Stublis, Select Charters, p. I 12.

3 Burton, Kidderminster, p. 58 .

${ }^{4}$ Bennett, Teikeshury, p. 32r: some of these customals couple heriot and relief while denying their existence within the lorough in question.

5 Tait, Mediveral Menchester, p. 70: “ cum burgensis moriatur heres ejus nullum aliud relesium dabit mihi nisi hujusmodi arma, scilicet gladium, vel arcum, vel lanceam."

"Whitaker, Hon hester, ii, 1) 212: the Manchester charter says" alicujusmodi arma," which according to the extent of 1322 meant the arms usually used by a burgess (Tait. Mediumal Mambester, p. 70).

7 Court Leet Records of .Hanchester, i, p. 167, a. 1574 . The court leet records alound in such entries as "ad hance curiam venit . . II. P. coram . . senescallo ifirlem . . . et admissus est tenens et dedit domino pugionem secundum consuetuedinem, que pugio appreciatus fuit ad xii d." 
owed, sometimes by the same tenant, ${ }^{1}$ and the two incidents were frequently confused. ${ }^{2}$ It is noteworthy that both relief and heriot at the three above-mentioned boroughs went to the lord of the borough, elsewhere they were apparently the chief lord's due, and this condition probably held good at Birmingham. ${ }^{3}$ At Lichfield heriot was an obligation resting on every burgage and seems always to have been a payment of money. ${ }^{4}$ At Oswestry heriot seems to have been paid to the chief lord from the effects of one who died tenant of a burgage. ${ }^{5}$ If this heriot were a rendering of arms a better example of survival could hardly be provided, for the original heriot was a military payment in kind from the dead man's goods, whether these goods had been given him by his lord or not, while relief came from the heir. The ideas are different though the result is the same. Heriot at Oswestry was the same as the heriot of Canute's law; at Tutbury and Uttoxeter also it retained its ancient meaning, ${ }^{6}$ though the word itself is denied, no doubt for the reason that the heriot of the country at the time of the record ${ }^{7}$ was universally a best chattel or best beast.

It seems that burgesses before the Conquest were fairly well accustomed to rendering heriot, though the incident was by no

${ }^{1}$ Court Records of Manchester, i, p. 204: a tenant who paid about a year's rent as relief rendered also a dagger which was once his father's. Heriots often appear as $6 \mathrm{~d}$.; on one occasion this amount was paid for a heriot and a relief as well (ibid., i, p. 42).

${ }^{2}$ Heginbotham, Stockport, i, p. I62. At the great leet of ${ }^{5} 569$ a burgess's son, at admission as a tenant, "soluit Relium viz. Abyll " (a bill). The Norman superstructure and the Saxon substructure are commingled here.

${ }^{3}$ Mrs. J. R. Green, Town Life in the Fifteenth Century (I894), i, p. 20I: the heriot seems to have been a bill or pole-ax, or 4 od. in commutation.

${ }^{4}$ Harwood, Lichfield, p. 38r. Though paid in money it seems rather a commutation for the heriot. According to the corporation records a survey (extent) in $26 \mathrm{Ed}$. ( ? IV) showed that there were then $286 \frac{1}{2}$ burgages, each of which 'payeth for heriot.'

5 Cathrall, Oswestry, p. 47: "whoever lived in the house of a burgess, and happened to die there, the burgess was to have a heriot after his decease." The customal does not state whether the heriot was a chattel or a commutation therefor.

${ }^{6}$ Mosley, Tutbury, pp. 367-368: " the burgesses of Tutbury . . . [and] Uttoxeter ... shall pay noe herryotts nor frythsilver, nor rent hens nor other duty, but after the deathe of theire ancestors, the king shall have theire " (i.e., the ancestors') "chiefe weapon in lieu of a herryott." The rendering is to the lord of the borough: cf. Manchester and Stockport.

72 Henry V. 
means universal. ${ }^{1}$ Perhaps this may help to explain its infrequency in the later period, for where retained, its military character raised it above the villein heriot to the feudal relief, while this very military nature made it inapplicable to the larger commercial boroughs. ${ }^{2}$

\section{Escheat}

This incident will be dealt with here in its accurate meaning the lapse or reversion of an estate to the next lord on the failure of heirs, the term heir being used in the strict feudal sense. ${ }^{3}$ Borough charters and customals rarely mention the matter, but the Calendars of Inquisitions post mortem, the Hundred Rolls, records of transfer and descent of tenements, and sources of like nature contain abundant evidence to show that escheat was the lord's due; that a tenement which lacked an heir did not fall to the community, as was the custom in many German cities; and that his right to escheat was seldom disputed openly. They also show that the lord, if he were not a burgess, had to be watchful that he got his due. In dealing with the subject we shall treat in order: recognition of the lord's right; his claims where he fears that he is losing escheats; his actual loss; and his giving the right to take escheats to a person or to a community.

At Ipswich the customal recognized the chief lord's right to escheat "when it is due by law," ${ }_{4}^{4}$ and at Berwick, after its reconquest by Edward III, many tenements escheated to the king. not it would seem on account of the townsmen's resistance, which could be called treason, but because death or expulsion of the holders had left their messuages tenantless. ${ }^{5}$ Burgages

1 Ballard, Domesday Boroughs, p. 49.

2 At Launceston there is casual reference to heriot. In the ith century there are two tenements which owe "heriotes whan itt fallith" but they seem to be outsicle the borough; the heriot is part of the rent. See Peter, Launceston, pp. 174. 180.

${ }^{3}$ In the sources escheat is often used in the sense of forfeiture. For the latter incident see p. 33 .

4 Domesday de Gippewyz, p. I4I; Bacon, Annalls of I pswiche, p. 34 . In 1376 there is a record of a messuage " holden of the king " which escheated because the holder "was a bastard and died without heire" and therefore was kinless (ibid., p. 78 ; see also p. 79 for an escheat by death).

s Scott, Beraick, pp. 249-250: they fell to the king not as lord of the borough 
escheated ' for lack of heirs' in Liverpool, ${ }^{1}$ Liskeard, where the burgesses were seemingly responsible for the rent, ${ }^{2}$ and Hull, ${ }^{3}$ where however the conscience of the community had been awakened by an inquisition ad quod damnum.

In Rospont (Ross), and in Old Ross before it had quite lost its burghal character, tenements fell into the hand of the king's representative or justiciar, at that time $R$. Bigod, and thence apparently into the king's hand, though the earl for a time retained them. ${ }^{4}$ At Cambridge ${ }^{5}$ and Leicester ${ }^{6}$ the king was careful to retain his right to escheats while parting with other privileges; at Richmond his example was followed by its earl.7 Norwich illustrates the common usage in respect to escheat with so clear, concise, and yet comprehensive a record that the report of the inquest-jury concerning an escheated tenement in that city merits quotation: "Reginald de Cressy, parson of churches, had a bastard daughter, Isabel, whom he enfeoffed of the said messuage. Robert le Blund took her to wife and they had a

(see London and Oxford custom, p. 27 below) but because he was the only lord remaining. Burgages in the connected barony of Lindsay escheated at the same time (Berwick, p. 25I).

1 Picton, Liverpool Records, i, p. I2: the bailiffs account for the rent of "three parts of one burgage and of five sellions of land which fell into the hands of the Lord by the death of John Botiller a bastard," $a$. 1346 .

2 Allen, Liskeard, p. 21: the burgesses in I301 "render for a certain burgage thereof escheat 2s. 6d." in addition to their usual firma burgi.

${ }^{3}$ Frost, Hull, p. 25: the writ concerned a messuage which I. " quondam burgensis dicte ville" held of the king and which, through I.'s death, had come into the king's hand.

4 Hore, Wexford, i, p. I43. In I 280-8I, the praepositus of Ross returns, among his other accounts, the rents of certain stalls " which are taken into the hand of the Earl by escheat." In Old Ross, probably still a borough, among the accounts is one concerning a tenement escheated through the death of the previous holder (Hore, Wexford, i, p. I 53). In I $304-0_{5}$ the king's escheator for Ireland stated that R. Bigod "was in seisin of a certain tenement in the town of Ross as of escheat by the death of R. M." (ibid., i, p. I66).

5 Cooper, Cambridge, i, p. 92. In 1340 the king granted the new-made Earl of Cambridge the castle and other royal property in Cambridge " saving to the king ... escheats pertaining to the Castle and town."

- Bateson, Records of Leicester, ii, p. 220 . The lease of the farm of the borough from Henry IV in 1404 saves to the king his escheats.

${ }^{7}$ C. P. R., a. 1436-4I, p. 509: John, Earl of Richmond, granted the borough with pasture to the burgesses for $£_{40}$ in I 268 , escheats to remain with him. 
son, Reginald, who eight years ago withdrew from England, and because the jury know not whether he is alive or dead and there is no other heir, the messuage has been taken into the king's hands, and delivered to the bailiffs of Norwich until the king shall direct what he wills." 1

Messuages are spoken of as being or having been escheats to the king in Windsor ${ }^{2}$ and Northampton; ${ }^{3}$ at Southampton escheats were due the lord of the borough, in this case the king. Because these instances show that the borough lord was entitled to escheats it does not follow that they went to him over mesne lord's heads; such is not the rule.

In the case of the luckless Jews, however, no rule except the king's caprice seems to have held. "What belonged to the Jews belonged to the king," and many a messuage passed into his hands, though commonly under semi-legal forms, the heir's rights being apparently completely ignored, only because the holder was a Jew. This is robbery rather than escheat; it is an inheritance tax on realty of one hundred per cent, much like ancient theoretical relief and not very different from actual relief in the days of William the Red. Probably the reason why it was regarded as escheat was because the king was in a sense a Jew's only lord. ${ }^{5}$

${ }^{1}$ C. I. M., i, p. I66 (47 Henry III): the escheator is not known for the writ (original) is lost. Eight years are not necessarily the limit of time beyond which an heir loses his rights.

${ }^{2} C$. C. K.. i, p. 444 : the date is 1255 and it is doubtful whether Windsor was a borough at that time.

${ }^{3}$ C.C. R., i, p. 452, a. 1256 : the king granted a house which had come to him by the death of the holder (Leo, a Jew) "without an heir and intestate, so that the king may give it to whom he will." In the same year the king recovered a tenement in Northampton against. Idam the Fleming as his escheat.

4 Calendarium Inquisitionum ad quod damnum, p. 348, a, r 402 : "W. B. W. defunctus tenuit de nobis in burgagio die quo obiit... tenementa. . que ad nos tanquam escactia nostra pertinere debent."

s R. H., i, p. I Iq. At York the jurstores " dicunt quod domus que fuit Isaac Judei debet esse escactal domini Regis eo quod quidam murus dicte domus ofpressit cum unde obiit." "This is called an escheat; it is as much a deochand. The house falls on its owner and thereby into the king's hand. Also (ibid., p. 119) at York a burgess " amisit in Judaisno" a mill, etc.; the Jew died; " unde deberent esse escacta domini regis." There is no word of heirs and the latter case shows how the king robbed his (hristian subjects by robbing the Jews, for if the mill had been mortgaged to the Jew the mortgagor had no redress, there was no equity of redemp- 
It is probable that if a Jew's tenement had any other lord than the king such a lord lost his rights. An escheat might come to the lord through the late holder's neglect to make a will ${ }^{1}$ and a religiosus who kept his vows sometimes thereby enriched his chief lord. ${ }^{2}$ These are instances of escheat to a chief lord of the fee without the borough, but there were the chief lords within; almost any burgess might stand in that position for almost any tenement. So might the commonalty, which could and did hold real estate, at an early period in some boroughs, and in such cases took escheats. ${ }^{3}$ In London, ${ }^{4}$ Canterbury, ${ }^{5}$ and probably Bristol and Oxford, ${ }^{6}$ all escheats went to the lord of the borough, in these cases the king; chief and other mesne lords lost their rights.

When escheats were due to the lord of the borough they seem to have had a constant tendency to slip away from him. This feature is present in many records of which real property is the subject, sometimes only as an impression gathered from the spirit of the record, but often specifically expressed in efforts toward prevention, as in the general directions in the Hundred Rolls: " touching the king's farmers who hold cities, boroughs, or other manors of the king at fee-farm and who by reason of the farm take the escheats and alienate or retain them." 7 In the case of a borough

tion then. All is done through a jury, however, and nothing before the mortgagee's death. Therefore caveat mortgagor.

1 C. $I . M$., i, p. 228: in London in 53 Henry III certain houses "late of the said W. . . . are the king's escheat because the said W. died without heir, and made no mention of them in his will."

${ }^{2} C . I . M .$, i, p. 242,54 Henry III. A tenement at Cumbe, held of the king in chief, escheats to him for lack of heirs. The holder was a cappelanus, evidently not of the style of Reginald of Norwich.

${ }^{3}$ Gilbert, Records of Dublin, i, p. Io6. After the great fire of 285 the Dublin authorities let a piece of ground which had "escheated to the citizens." A "notification' by the mayor and commonalty of that city (ibid., p. 88) states that "when any person holding a tenement in fee from a citizen dies without direct heirs, the tenement reverts as his escheat to the citizen from whom he held it," which is what one whould expect, "but if there be a collateral heir he is to have seisin of the tenement." Such a notification seems needless. Possibly the burgesses feared the king's, or his officials' intervention.

${ }^{4}$ C.C. R., i, p. 5 r ; P. R. O., coram rege, I99, m. 80; Plac. Westmon. Abbr., p. 3 Io.

5 P. R. O., coram rege, $256, \mathrm{~m}$. I4 I.

${ }^{6}$ For authority and discussion of reasons see Forfeiture.

7 R. H., ii, p. 392; Maitland, Township and Borough, app., par. iा6. 
at fee-farm, as almost all the larger boroughs were at this period, those against whom the inquiry was directed would be the burgesses as a community, for the fact of corporateness is there whether the theory is or is not. ${ }^{1}$ Nor was the king the only lord of a borough who saw his escheats threatened; at Leicester the lord had difficulty in keeping his escheated tenements out of the hands of the burgesses, who had adopted the simple and well-intentioned though ultimately futile expedient of refusing to pay the rents thereof. ${ }^{2}$

In addition to these general cases there are many instances of attempts to get isolated escheats, or at least to make sure that such should not escape when they became escheats. It was even possible for the king as lord to give or sell a tenement never lawfully his on the pretence that it was an escheat, his efforts however meeting with no more success than those of the Leicester burgesses. ${ }^{3}$ The royal government seems to have maintained a system of espionage over escheats in the boroughs, for it nearly always knew more about them than did the borough magistrates, notwithstanding the fact that the mayor, where

1 To the sheriff of Bristol in 1384 came a writ of praecipe to see to it that Anne (of Bohemia), Richard's first consort, to whom he had given his privileges and profits in Bristol, should not lose her rights. "Cum per . . . litteras nostras patentes dederimus... consorti Anne... diversa tenementa cum escaetis omnibus tenementis . . " (Bickley, Litlle Red Book of Bristol, i, p. I 26). It would appear that the Bristol community or corporation, for the city was a county borough in 1384. were trying to keep the king's escheats, as the city of Cambridge may have tried in 1279 .

2 Bateson, Records of Leicester, ii, pp. 150,159 . In $1377_{-78}$ the mayor and burgesses were charged with three years' arrears of rent of tenements "being in the hand of the lord by escheat." It seems that the defendants had been applying the rents of the tenements in question to their own use " contrary to the form of the same indenture thus agreed upon with the council of the lord " by which indenture "the escheats of free tenements" are saved to the lord. The burgesses lost their case and had to pay $\mathfrak{E}_{\mathrm{t}}$ and more of arrears to the lord, John of (iatunt.

${ }^{3}$ C.I. M., i, p. 227. At Cambridge in 53 IIenry III the inquest-jury found that "the houses late of the said T. are not the king's escheat through his" (i.e., T.'s) " death, and the king can not give them away without injury to Luke" because the houses in quention had been given "to the said $\mathrm{T}$. and the heirs of his body, with remaincler to the said Luke," strengthened by a final concord of the whole transaction marle at Westminster in 41 llenry III. Of course the king lost the messuage, but so sure was he of it that he hard given his supposititious and premature escheat to Sir Ralph l'irot, "who had ejected the said Luke by force." 
there was one, was commonly the king's escheator. Even the humblest tenement was watched. At Suwerk (Southwark) it required the efforts of an inquest-jury to keep a stone-cutter's house from seizure. ${ }^{1}$

The king was not the only lord who thought it better to have claimed and lost than never to have claimed at all. It seems that on a few occasions certain bishops were either led astray by his example, or were forced into illegal action, or else that the king impelled the keepers of the bishoprics during vacancy into like indefensible proceedings. ${ }^{2}$ The last is certainly the correct interpretation of the king's attempts to acquire burgages at Winchester and Canterbury, and the inwardness of the proceeding seems to be that the king was desirous of getting what he could out of the bishoprics during vacancy, escheats included. Such falling to him, he would have the right to give them or to sell them, though their rents would still be payable to the bishop

1 In 50 Henry III an inquisition post mortem was held in respect to a marbeler's tenements, even though he had a daughter, who was also heir to his deceased brother's tenement. In $3 \mathrm{I}$ Henry III at Hereford (C. $I . M ., \mathrm{i}, \mathrm{p} .25)$ the finding in respect to a messuage balked the king's attempt. In 4 I Henry III (C. I. M., i, pp. II3-II4) the heirs of Patrick de Chaors (Cahors) retained their tenements against the king's attempt at seizure.

${ }^{2}$ C. I. M., i, p. ${ }^{3} 35$ (45 Henry III). A writ addressed to the keeper of the bishopric of Winchester ordered an inquisition concerning "divers tenements (in Winchester) held of divers lords by divers rents," most of the tenements having been in the hands of one man whose death was the cause of the inquisition. He had heirs however so the tenements could " in no wise . . . be the escheat of the said bishopric."

At Thame there are similar instances of endeavors to acquire lands held 'in burgagio,' notwithstanding the fact that the deceased tenant had "plures consanguineos de terris et tenementis praedictis haereditabiles," $49 \mathrm{Ed}$. III. One J. died seized in fee "de uno burgagio . . . in villa pracdicta" (Thame) in 47 Ed. III. The bishop of Lincoln, who was the offender in each case, "intravit et ita tenet ut escaetam . . . pro defecta heredum, ubi plures sunt de sanguine praedicti J." The messuages were the object of another unsuccessful attempt in I7 Rich. II (Madox, Firma Burgi, p. 4I). Thame may have been a borough, but it is doubtful, though the messuages are repeatedly said to be held 'in burgagio.' If it was not a borough the law would consider the tenements held in socage.

At Canterbury in 55 Henry III (C. $I . M$., i, p. 258) was another attempt to acquire tenements while the archbishopric was in the hands of a keeper. The burgess, however, "held nothing of the archbishopric in chief" (that is, the archbishop was not his chief lord) and "it cannot be the king's escheat, for he left an heir." 
if he were chief lord. Perhaps the king's seeming avidity is due to the thoroughness of the royal officials and the accuracy of their accounts as much as to royal greed. The king's own property in Winchester was watched over quite as sharply, ${ }^{1}$ and to judge from the care with which the king, or rather his ministers for him, looked after his chances to get escheats, in which laudable and strenuous efforts no reign shows so much misdirected energy as Henry III's, it seems almost impossible that any tenement could escape which should come to him by law; and what is true of the royal boroughs is probably not untrue of those held by barons and bishops.

Yet there is evidence that escheats sometimes did escape the lord for a time at least, and that occasionally an isolated tenement got out of his hand, as a case in London during the progress of the 'Great Inquiry' of 1279 illustrates; what makes the instance odder is that the tenement in question of which the king could not keep track seems to have been a royal wine-cellar. ${ }^{2}$ That the London jurors should be 'wholly ignorant' is not so odd; ignorance in such matters was wide-spread throughout the boroughs. Compared with the extent of their knowledge of other subjects it seems especially dense among the Cambridge jurors. ${ }^{3}$ Another possible way for the king to lose his escheats lay in their detention by one to whom he had granted a borough. ${ }^{4}$

${ }^{1} C . I . M ., \mathrm{i}, \mathrm{p} .283$. The finding of the inquest-jury was that a certain messuage was not the king's escheat for he had given "it to the said G. and his heirs, and he had a son." Again in another inquisition-finding certain houses "are not the king's escheat through " R.'s death on account of the manner of their acquisition. The writ is to the mayor and bailiffs. Both inquests were in 56 Henry III.

${ }^{2}$ R. $H ., \mathrm{i}, \mathrm{p} .422$. Concerning this tenement the juratores " dicunt quod quedam domus quam W. H. tenet in civitate Londonia fuit aliquando in dominico corone domini regis et celarium ad vina domini regis hospitancla, qualiter et quomodo a manibus domini regis fuerit alienati, penitus ignorant." The tenement is inquired about and reported again; the jurors are still ignorant (ibid., pp. 429-430). The messuage may be a lawful escheat or it may have previously escheated and escaped the king, probalily the former.

${ }^{3}$ See $K .1 I$., ii, pp. 356 et seq., the Cambridgeshire inquest-finding.

- This grant of a borough was usually a grant by the king of whatever profits he got from the town; that is, it meant a grant of the farm of the borough or of the fee-farm rent (Firma Burgi) if the borough was so held. Only the smallest royal boroughs were commonly so granted, usually for life or a term of years. The grantee, who was as a rule a noble, or a bishop, or sometimes the 'king's consort,' 
There was also much indirect loss of escheat to both chief lords and the lord of the borough through alienation either to the community within which the tenement lay, or to a community of the religious. In addition it was possible for those whose duty it was to see that the king did not lose his lawful escheat to be instrumental in doing the very thing which they were supposed to prevent. ${ }^{1}$ In the baronial boroughs escheats may have escaped

commonly had the right to take escheats during the period of the grant (Bickley, Little Red Book of Bristol, i, p. I 26). This was not a permanent loss of escheats to the king as lord of the borough, but only of those which happened to fall in during the interval of the grant. The grantee however frequently did what he could to make the loss permanent even though he had never had any right whatever to take escheats. In 1223 the king complained to the archbishop of Dublin, justiciary of Ireland, that Thomas Fitz Anthony, who had been given the grant of the city of Cork, "as far as belongs to the king," in I $2{ }_{5} 5$ and who had had the Firma Burgi for three years to build the city wall, had detained some of the king's escheats (Caulfield, Council Book of Cork, pp. xii, xiii). The Firma Burgi never contained the rents (not original) or prices of escheated tenements, unless such were specifically indicated as being contained therein. The fact that Thomas Fitz Anthony, or any one else, had a grant of the Firma Burgi did not give him the slightest right to retain them. The chances for usurpation in Ireland were excellent about this time, and Thomas Fitz Anthony did not fail to improve them; in 1226 the prior of Cork complained that Thomas had disseized him of two burgages; the wave of objection went from prior to justiciary and justiciary to king, from whom came nothing but the advice that the prior might have an assize of novel disseisin, which he could have had in the first place for the asking under the burghal name of the assize of fresh force.

1 See Hore, Wexford, i, p. I66. The escheator said that while R. Bigod was holding lands in Ireland, and before he held them " to himself," he had alienated two tenements, which had escheated, "to the ... disherison of our lord the King." In like manner the king's escheators may have retained at least a part of the escheats, sometimes legally as the result of an agreement with the central government. Such an arrangement however was not likely to affect the boroughs to any extent, especially after the custom became general of making the mayor the escheator (see Mrs. J. R. Green, Town Life in the Fifteenth Century, i, p. 208, note r). According to Langland the lawyers too seem to have had their share in keeping his escheats from the king (ibid., p. 230, note 3 ) but the reference is probably to forfeiture. In Dublin in 1327 arose a case which looks as if the escheator had legally retained escheats: Fromund, son of Sir Nigel le Brun, had a dispute with the commonalty over property which both he and the commonalty had granted to a burgess. That he, and not the commonalty, had the right to give the tenements, which had come to him from his father who was escheator for Ireland, was decided by the court (Gilbert, Records of Dublin, i, pp. II5-II6). What gives the case the appearance of a retained escheat is the action of the commonalty, which had the disposal of property of its own which might escheat to it. 
the lord oftener than they did in the royal boroughs, for the barons' machinery of supervision was not so effective as the king's. Even beyond our period the burgesses of Hedon stood, and lost, a suit at law before they gave up illegally retained escheats. ${ }^{1}$ Though what happened at Hedon may have happened at many an obscure borough whose records still lie buried, such loss could not have been large compared with that due to corporate ownership. When a tenement passed to the commonalty or to the church that ended the lord's rights thereto; a universitas was the lord now, and as such took its escheat. ${ }^{2}$

1 Boyle, Hedon, pp. $219,225^{-227}$. In 1630 Lord Dunbar, who held the seigniory of Holderness, brought suit against the mayor, bailiffs, and burgesses of Hedon to recover his escheats. The defendants admitted that they had retained escheats and affirmed that they had a right to do so through immemorial custom, and also by virtue of charters and grants. Of these last however they had none to show, while their custom was by no means immemorial. They lost their case, although it was proved that for some years the community had kept escheats for lack of heirs.

2 At Bridport, probably temp. Ed. II, the bailiffs of Bridport along with their fellow-burgesses granted a tenement for a price paid down and a yearly rent, but the grant provided that in case the last holder came home " that the five marks so paid to the burgesses are to be returned." The community (lord) had taken its escheat but gave the former holder a chance to regain it (H. M. C., Rep., 6. p. 485 ).

At Dublin in 1318 the town magistrates ' set' a plot of ground to a burgess who is to hold it " until claimed by the lawful heir." If he should come the tenant may retain the land till paid for any buildings which he has erected. Again the community gives every chance to a possible holder (Gilbert, Records of Dublin, i, p. 1 i 7 ). Sometimes the borough and the church worked together (a rare case of agreement) as at Plymouth where the Old Black Book contains such items as: "that in case 1 . . . . die without heir the capital messuage of the late $\mathrm{N}$. . . [probably 1).'s father] will remain to the mayor and commonalty . . . for the use of St. A.'s church," an instance of the doctrine of uses to evalde the act De V'iris Religiosis. Both fcoffor and foofee are virtually immortal (II. MI. C., Rep., 9, pt. I, P. 272$)$.

At Bath early in Edward l's reign the jurors said " that the prior had acquired by grift or purchase, after he had taken the city to farm, 27 tenements in "perpetual alms,' wut of which the king had lost escheats and other emoluments" (King and Watts, Wunicipal Records of Bath, p. 15). The loss of an escheat might sometimes be considerable. In 1294 an inquisition ad guod damnum in Cambriclge showed that if certain messuages and land were given to the University of Cambrige, the king would be damaged ly the loss of the escheat to the extent of $f_{40}$ Maitland, Tounship and Borough, p. is 6 ). Even as late as the oth century possible loss of escheat seems 20 hatumt the royal exchequer. (ir. 1505 a commission reported that the sovereign would lese all escheats in (ardiff if certain privileges were granted 
Release in perpetuity of the right to take escheat was rare. The bishop of London seems to be the only one to do so when, among other privileges, he sold his right to take escheats to the men of Maldon. ${ }^{1}$ From the preceding instances it is clear that escheat in the boroughs was the chief lord's undoubted right, that the burgesses recognized this though they seldom exerted themselves to aid the borough-lord, that where it could be of no disadvantage to themselves they seemed quite willing to tell the truth when an inquisition was held, that the lord's claims (the lord king's at least) were frequent and usually unsuccessful, that he often lost his right on account of a tenement's falling into the dead hand, and that he seldom gave away or sold his right. Baronial and ecclesiastical boroughs excepted, the custom of the middle ages, though feudal in theory, was in practice and substance that of today; the king, that is the state, not the community within which the property lay, took property which lacked an heir or a mesne lord. The chief reason why escheats were so few was that an heir could be made by a will, and but for neglect on the part of the kinless holder to make a devise, and but for a custom in some boroughs which prohibited devise of inherited realty, a custom which waned with the middle ages, there need have been no such thing as burghal escheat. Even as it was, compared with the river of escheats which flowed from the country into the royal exchequer the stream from the boroughs was an intermittent rill.

\section{ForfeItURE}

Escheat is often used to mean escheat and forfeiture as well; each is a feudal incident. The history of escheat in the boroughs

to the Earl of Pembroke (Matthews, Cardiff Records, i, p. 347), and in 1649 there seem to have been disputes over escheats (ibid., p. 430).

${ }^{1}$ C. P. R., a. 1403, pp. 307-308. The previous custom saved to the bishop "all escheats of land within the town ... which shall always be reserved to him by reason of his lordship of the town." In the future, however, "if any escheat from any lands shall come to him ... within the town, the men of Maldon shall have a rent as much as the bishop used to have from such escheats." The three afore-mentioned widows (see Leicester, Lynn, Dover - Relief, p. 20), who busied themselves over homage and other terms of which they knew nothing, released escheats to the grantees, a meaningless proceeding in this case. 
was usually and in theory the same as in the country; the history of forfeiture seems to have been different. ${ }^{1}$ For forfeiture was more than a feudal incident, it touched every free holder of land, and in the boroughs very humble men might hold land; men who were quite as capable of committing felony as feudal holders, and, so the court leet records say, much more apt to commit it, though their chances to be guilty of treason were somewhat limited. In the country the felon's land was subject to 'year, day, and waste' by the king, ${ }^{2}$ after which it reverted to its lord unless the felony were treason, in which case the king kept it. Suppose a burgess guilty of felony. Did the king hold his tenement a year and a day and tear his house down, or, whether the king were or were not the chief lord, did he keep it for his own use? Before coming to any conclusion it seems better to let the records tell their story, for the peculiarities of burghal conditions necessarily led to modifications and variations of the practice, at least in the larger and commercial boroughs.

The course of a forfeiture at Norwich will answer the question for many boroughs. In 28 Edward I an inquisition was held concerning two messuages in Norwich which had come to the king as escheats (forfeitures) through the felony ${ }^{3}$ of their previous holders. Norwich was a royal borough and moreover each messuage was subject to a rent to the king's farm, and was therefore an original burgage; the king was lord of the borough and ultimate lord of the messuages. The felons did not hold of the king however; had they done so their messuages would have gone directly to him anyway; one felon held his tenement of St. Olave's church, the other of St. Augustine's. The churches therefore were mesne lords and there may have been others. Following the feudal custom the king would have had the right to his year, day, and waste, after which the churches would have had at least the land. Such was not the result however; the churches apparently retained their rents but the king got the messuages. At Norwich, in this instance at least, the king's rights overrode

1 Forfeiture of chattels is aside from our subject.

" The familiar annus, dies, et rastus of the sources. 'Waste' is sometimes callerl 'strip,' the right to denude or strip the felon's lands of trees, buildings, etc.

${ }^{3}$ But not treason; in such a case the name is used. 
those of mesne lords; the forfeitures went directly to him to be dealt with as he saw fit, so there is no question of year, day, and waste. ${ }^{1}$

In London both forfeiture and escheat were always the king's, whose right thereto was well recognized by the citizens and was a frequent matter of record by the courts. In a plea before the royal justices a somewhat quaint reason why this should be so was given; $i$. e., that because no citizen owed homage or fealty to any one but the king, therefore no one should have an escheat but him. Though burgesses did not do homage they swore fealty; that, however, is no reason at all for mesne lords' losing their right to escheat. For the real cause one must look deeper and among vulgar commercial transactions rather than chivalrous feudal formulas. ${ }^{2}$ Canterbury had the same custom as

1 Stanley v. Mayor, etc., of Norwich, f. 16, a. I300. According to the Norwich customal this was not the usual course of forfeiture in that city; a felon's tenements should go to the chief lord, who pays an appraised value as year, day and waste: "et in casu ubi fugitivus terram abjurans habeat terras et tenementa in civitate et illa tenuerit de aliquo concive . . . per certum servicium annuum unde eschaeta . . debuerit ... accedere . . apprecietur annus et vastus ... ad opus domini Regis" (Hudson and Tingey, Records of Norwich, i, p. 140). It is hardly likely that there were two rules for forfeiture in Norwich, one for lay and the other for spiritual chief lords. Yet in 2 Ed. III: " R. le T. tenuit unum messuagium de priore Sancte Trinitatis Norwici, et idem R. fecit quandam feloniam . . . et eo pretextu idem prior dictum messuagium seisiviset tanquam escaetum " (Calendarium Rotulorum Chartarum et Inquisitionum ad quod damnum, p. 289). The two messuages of the record of 1300 never went to their chief lords; the king, Edward I, sold them: "Extension to G. de W. of Norwich . . . in consideration of a fine " (at the exchequer) " of a grant" of two messuages in Norwich " escheated to the king by reason of ... felony" (C.P.R., a. 1300, p. 558). The result was the same in either case; the king got the tenement itself or its value.

2 In London forfeiture and escheat are always the king's, as declared before the justiciary, Hubert de Burgh, in 5 and ro Henry III (Plac. Westmon. Abbr., p. 310). Conditional estates however did not escheat to the king (ibid., pp. 310 and $317)$.

In 1227 the king granted land " which is the king's escheat according to the liberty of the city of London, whereby all forfeitures of whomsoever they are held escheat to the king, as admitted at the court held before the king at the Tower" (C. C. R., i, p. $5^{\mathrm{r}}$ ).

The custom of London in the matter of both escheat and forfeiture is definitely explained in a so far unpublished record of 2 Ed. II: " Major et cives dicunt quod omnes escaetae infra libertatem civitatis Londoniae de quocumque terrae teneantur. sunt domini regis sive escaetae per feloniam sive alio modo" (P. R. O., coram rege, 
London in regard to forfeiture ${ }^{1}$ and escheat as well, the king's right to the latter being confirmed by a jury of the citizens empanelled to settle a dispute arising out of the ownership of tenements which a burgess claimed to hold by hereditary descent of the aldermanry of Westgate. ${ }^{2}$ London and Canterbury are not peculiar in their custom in respect to forfeiture. At Oxford, ${ }^{3}$ Grimsby, ${ }^{4}$ Newcastle-on-Tyne, ${ }^{5}$ and very probably at Bristol, ${ }^{6}$ and York, ${ }^{7}$ mesne lords had lost their right to forfeitures and had been reduced to what Maitland called ' men with rent-charges.' When it was legally decided that this was because the burgesses

194, m. 85: the above-quoted pleas of 5 and 1o Henry III are also cited as previous records).

In 3 Ed. II the king by judgment secured a messuage in London belonging to a bastard who died without heirs; again it was declared that all escheats in London belonged to the king (P. R. O., coram rege, $199, \mathrm{~m}$. 80, extracts from 5 and 10 Henry III given on $\mathrm{m} .86$ dorse). "Et hac racione debet dominus rex habere hujusmodi escaeta [i.e., both forfeiture and escheat] et non alius quia nullus de civitate debet facere homagium vel fidelitatem nisi tantum domino regi " (coram rege, $\mathrm{m} .80$ dorse). This is the fanciful and inconsequent reason mentioned in the text.

1 Plac. Westmon. Abbr., p. 319. In 8 Edward II in the course of a suit before the royal justices at Westminster it was decided that the king had all forfeitures in Canterbury.

2 The question at issue was whether tenements held of this aldermanry should escheat to the burgess or the king, " et super hoc jur[atores] istius civitatis quesiti si quis habeat escaetam in civitate ista alius quam dominus rex dicunt per sacramentum quod non" (P. R. O., coram rege, 256, m. i4 i).

${ }^{3}$ Calendarium Inquisitionum ad quod damnum, p. 302, no. 26, 1 I Ed. III: " unum toftum . . . in suburbio [Oxoniae] quod fuit Vini le Longe pro felonia quam idem Vinus fecit suspensus et quod ad manus Regis ut escata [forfeiture] devenit."

- H. M. C., Rep., 14, app., pt. 8, p. 245.

5 Calendarium Inquisitionum ad quod damnum, p. 342, 50 Ed. III: the juratores " dicunt quod omnia terrae et tenementa . . . in Novo Castro super Tynam . . . et que ad manus domini regis tanquam escaetae devenerunt pro eo quod feloniam fecit."

"Pike, Fearbooks of the Reign of Edward the Third, years xiv and xv, p. 86 (Michaelmas term, a. I340). John de Berkelay brought a writ of escheat against John de Weston, demanding a messuage in the suburbs of Bristol. The defendant claimed that the king should have all felonious escheats, of which this was one; and that he had been enfeoffed by the king. There is no record of juclgment, but on the plearlings the plaintiff seems to be entitled thereto. See ibid., pp. 184I 88 .

${ }^{7}$ C. P. R., a. 1270, p. 337. The mayor (with others) was empowered to sell forfeited tenements. The felons were Jews. See ibid., a. 1283, p. 85, where the king grants forfeited tenements in Montgomery. 
owed homage and fealty to no one but the king, the court was not even stating a fact, much less giving a reason. For the reason one must look to general conditions and tendencies in the boroughs, particularly in regard to lands and tenements. Take London as an example. It was a royal borough, but besides the king, all sorts and conditions of men - nobles, bishops and abbots, laymen and religiosi of all degrees - held tenements therein. At one time there were many separate jurisdictions (sokes), but the king was the only practical source of privileges and to him the burgesses looked. He could and did grant liberties over mesne lords' heads, and the rights of those who had sac and soc gradually diminished till only a few sokes remained. Contemporaneously, tenements were bought and sold, some of them many times. Where and who were the 'chief lords' of these tenements? There had in one sense never been chief lords for some. The lord's rights, escheat it would seem among them, gradually slip away from him; the king's take their place, for he never dies and always his functions increase.

One should not assume this process to be universal; in the baronial and abbatial boroughs and even in many royal boroughs one finds the lord retaining his escheats when he can, but the king does not take them. Probably this is because of the lack of commerce and the consequent comparative simplicity of the tenure in such places: the rungs in the ladder were few and easy to be seen. In London and other trading towns tenurial heterogeneity had caused the ladder to fall to pieces: the king took all. ${ }^{1}$

While it is apparent that in such cities as London, Bristol, and others of like class any lord who stood between the king and the felon lost his right to forfeitures, yet in some of the grants or

1 The king had a large source of income from his forfeitures, or had a chance to get such unless he chose to forego it by giving them away. The Hundred Rolls contain many such records as: "juratores dicunt quod domus quod fuit J. de $\mathbf{M}$. per excaitam [i.e., forisfacturam] fuit in manu domini regis Henrici et dedit eam R. W." (R. H., i, p. 427). Other instances of ' giving' are frequent though no doubt there was often a fine at the exchequer. Sometimes the felony or treason is to be inferred, as in the following record: "juratores dicunt quod quedam domus . . . fuit excaeta [forf.] domini regis per mortem W. E. . . . detracti" (R. H., i, p. 430); when one has been 'drawn' the rest may be taken for granted. 
regrants of tenements which had been forfeited on account of felony the king seems to have kept mesne lords in mind. Henry III did not forget the mesne lords when he gave a few forfeited London tenements, ${ }^{1}$ part to the bishop of Chichester ${ }^{2}$ and part to Hubert de Burgh, and even in a grant to a simple citizen the chief lord was guaranteed his rent. ${ }^{3}$ At Oxford and Cambridge there are instances of retention of rents by chief lords notwithstanding forfeiture of the tenements to the king. ${ }^{4} \quad$ This specific saving of his service to the lord of the fee seems unnecessary on the king's part; such services were of the nature of liens on the forfeited tenements and as such would still be payable to their holders. They were, however, usually so small that it made little difference whether the former lord retained them or not, and it may be that the king himself was at times the chief lord whose services were saved. This seems to have been the case in respect to a tenement in London granted to the Earl of Pembroke by Henry III; ${ }^{5}$ it may be and probably is exceptional, for in the bulk of the grants of such tenements there is either no mention whatever made of any services, or else their nature indicates that they are not owed to the king. ${ }^{6}$

${ }^{1} C$. C. R., i, pp. 67-88, a. 1227. The London custom as regards forfeiture is recited, but the lords of the fee are saved their rents and services.

2 Ibid., p. 68.

${ }^{3}$ Ibid., p. 68. The tenement was the "king's escheat for forgery" ; the grant (? sale) concludes: "saving to the lords of the fee their due service." In $122 \mathrm{~S}$ in a grant of tenements to William Marshal, Earl of Pembroke, the earl is "to hold the sime by rendering the services (lue to the lords of the fee " (ibid., p. 74). In the other grants there was a rent to the king in each case as well as one to the chief lord.

4C.C.R., i, p. 60. In 1227 the king granterl a tenement in Oxford " which is the king's escheat" (forfeit) to Robert Brain who however must do "the service due to the lord of the fee "and pay a rent to the king as well. In 1224 the men of Cambridge marle fine for 40 marks to get a house which had belonged to Benjanin the Jew, and which was then in the king's hands. The tenement rendered to the king "one mark, and to the chicf lord . . two shillings per annum" (Cooper, Cambridge, i, [1. 39). The chief lord kept his rent, which the burgesses must hereafter pay to him. Was he or the king chief lord thereafter? The king, undoubtedly; the burgess is now a man with a rent-charge.

S C. ( $. . R ., \mathrm{i}, \mathrm{p}, 79$, a. 1228 . The earl at once sold the house and in his deed saved "the scrvice of the chicf lorl of the fee, that is 8d. yearly for the socage of the king."

6 As at Norwich where the grant of forfeited tenements of a previous quotation 
The scanty records of felonious escheat in baronial or episcopal boroughs seem to indicate that the forfeitures there were the bishop's or baron's, and that the king did not interfere. Whether the baron in his barony overrode mesne lords' claims as did the king in his kingdom is not sure but is very probable. This seems to be the case at New Ross in Ireland where the lord of the borough, R. Bigod, certainly got forfeitures, ${ }^{1}$ while there is no doubt that the borough lord took forfeitures at Maldon ${ }^{2}$ where he sold his right to the burgesses, or at Farnham ${ }^{3}$ where he retained it.

One cannot go very deeply into the question of forfeitures without noticing how large an amount of real property was taken from the Jews in the latter half of the thirteenth century. Such seizures were sometimes legitimate enough, but many of them consisted in nothing but preferring a charge of felony as a preliminary to taking a Jew's tenement. The importance of this subject here does not lie in its connection with the tenure under which the Jews held their tenements, for they held as did the burgesses, under burgage tenure, nor yet as illustrating the fact that a Jew and his property were the king's, but as showing how far the king controlled forfeiture. Unless he had the right to felonious escheat regardless of the mesne lord the king could not have seized a tenement held by a Jew more easily than a tenement held by any one else, excepting of course the case where

specifies the king's service, rd., and adds " and doing the services therefor due and accustomed to the other lords of that fee," i.e., the churches (Stanley v. Mayor, etc., f. 22). The bulk of royal grants of forfeited tenements, those in London being naturally the greatest in number, have no word of saved services.

1 Hore, Wexford, i, p. $\mathrm{I}_{5} \mathrm{r}$. In $\mathrm{I}_{2} 84-85$ the praepositus of New Ross accounted for the rent of a certain escheat in the earl's hand for felony. In I280-8I he had accounted for "stalls . . taken into the hand of the Earl by escheat" (ibid., p. 143); the "taken" seems to indicate that they were forfeitures. The earl of the accounts, $R$. Bigod the marshal, seems to have had a sort of palatine jurisdiction in Ireland at this period and may have been taking forfeitures in that capacity, but the probability is against it, the escheats apparently coming from his own barony (ibid., p. 66).

${ }^{2}$ C. P. R., a. 1403, p. 308 . The bishop of London was lord of Maldon.

3 Parliamentary Papers, I835, xxiv, p. 732. In 1452 William of Waynflete, bishop of Winchester, granted Farnham to its burgesses, escheats of felons' tenements and chattels excepted. 
the king was chief lord, as he would be if the burgage were original or if the holder had bought it outright; for in a royal borough he who holds of no one else holds of the king. ${ }^{1}$ The fact that the king could acquire so much real property under cover of charges of felony shows the far-reaching influence of the central government in the matter of forfeiture. ${ }^{2}$

In the royal boroughs so far dealt with forfeiture was the king's; there was consequently no question of year, day, or waste. There were other royal boroughs however where the custom in respect to forfeiture was quite different, and whose customs in this matter differed among themselves. At Sandwich the king had year and day of a felon's tenement, which then passed to the community. ${ }^{3}$ At Dublin the king had year and day, the tenement then reverting to the chief lord. ${ }^{4}$ At Rye the mayor, probably for the community, had year and day of the felon's realty, which then went to his heir, or if he should have none, to the chief lord. ${ }^{5}$ At Dover a distinction was made between a felon

1 The alternative conclusion is that mesne lords had no rights at all, except to rent-charges; the course of escheat shows that they had rights, save in London and a few other large towns.

2 A process at Lincoln illustrates one of the methods used by the central government to acquire tenements held by Jews. It is certainly not escheat in the true sense of the word and not a felony in the ordinary sense, yet it entailed forfeiture all the same: according to a "report from the Justices of the Jews . . the said heirs appear from the rolls of the Exchequer of the Jews to have made no fine to have the said house, which is consequently the king's escheat, to give to whom he will " (C. C. R., ii, p. 224, a. 1280 . See also C. $I$. M., i, p. 242, 54 Henry III).

"Boys, Sandwich, p. 463: "If the accused be convicted" (of felony) "and suffer judgment, his goods are forieited to the king, and his houses and rents within the liberty to the mayor and commonalty, after the king has possessed them for a year and a day "; there is no word of waste.

- Gilbert, Records of Dublin, i, p. 88, c.a.1225-54: "Should a tenant of this class" (i.e., one who holds a tenement in fee from a citizen) "be guilty of felony, or otherwise forfeit his tenement, the latter remains in the King's hands for a year and a day, after which it reverts to the citizen from whom it was held ": again no word of waste. This clause of the customal is probably for all other chief lords than the king.

"Customal of Rye, quoted by Lyon, Dozer, ii, p. 349: "if he [the felon] be committed [i.e., convicted] then all his goods be forfeited to the town, and all his house rents and possessions, being of the franchise, shall be in the mayor's hands for a year and a day, and then to return to the heir of him that is appealed. And if no heir, then to the tenant of the lord of the fee." 
who left his country for his country's good and one who remained to be hanged. He who went must keep the highway to the port, not a hard condition at Dover, and if he left the country the king had year and day of his tenements (without waste), which then reverted to the chief lord. If, however, the felon suffered death, while the king had year and day as before, the tenements went to the felon's heir, a plain inducement to stay and be hanged. ${ }^{1}$

Such is forfeiture in Dublin and the Cinque Ports. How long they had had these customs is unknown. The Dublin customal is probably the oldest. Its date is problematical. ${ }^{2}$ Of those of the Cinque Ports the Rye customal is the oldest in compilation. Most of the rest were drawn up in the fifteenth century. $^{3}$ How ' customary' they were is shown by the differences in regard to forfeiture. They agree in this, that the king never retained a felon's messuage beyond a year and a day and that there was no waste, but the ultimate destination of the tenement varied among chief lord, heir, and commonalty. The customal does not state what happened at Dover to the tenements of a felon who did not 'leave the way to the port,' nor in what it advantaged any one but his heir if he chose to stay and be hanged, or thrown from Sharpness. ${ }^{4}$ It would not be surprising

${ }^{1}$ Customal of Dover, quoted by Lyon, Dover, ii, p. 271: " if he went out of the way, he forfeited his tenements to the king, for the holding a year and a day without waste; and after the year and a day then to the lord of the fee, if any; but when a felon suffers death, the king shall have all the profit of his lands and tenements a year and a day, and then they shall be delivered to the heir in gavelkind."

Heir in gavelkind probably means only the heir under the non-military tenure which was peculiar to Kent; burgage tenure, being non-military, would be considered of the same nature. The burgesses of Canterbury and Dover held "gavelkind land in and rourd the bounds of their cities" (Elton, Tenures of Kent, p. 152). In Kent a felon's heir did not lose his land; 'the father [went] to the bough, the son to the plough.' See Pollock and Maitland, History of English Law, i, p. I87.

2 The Dublin and the Bristol custom differ in respect to forfeiture. The former city had Danish customs from an early date.

${ }^{3}$ In her collection of Borough Customs Miss Bateson has been at great pains to date nearly every compilation. Such dates are of value when there are two or more compilations which differ from each other and so show how customs in a borough might change, for we know that of tentimes they did change, - that was one of the advantages of a customal. Otherwise an approximate date is sufficient; customs are always older than the customal which embodies them.

${ }^{4}$ The felon's death at Dover. See Lyon, Dover, ii, p. 272. Probably one who left the way was put to death, the usual custom. 
if Dover heirs often urged their felon fathers not to abjure the realm.

At times the king granted the right to take forfeitures to a borough, though not necessarily in perpetuity, in answer to a petition from the burgesses, who commonly pleaded their poverty or their calamities. Cambridge ${ }^{1}$ and Huntingdon ${ }^{2}$ had such grants. Henry V released 'forfeited issues' to the mayor and community of Leicester, ${ }^{3}$ but whether he allowed them to keep such is not certain; the reference may be only to issues which the town has forfeited. Edward IV granted year, day, and waste of a felon's or an outlaw's tenement to the citizens of Rochester ${ }^{4}$ and the burgesses of Ludlow; ${ }^{5}$ in these instances it seems as if the chief lord had retained the reversion after a year and a day.

From the face of this grant it may seem that Ludlow and Rochester should be placed among such boroughs as Dublin and the Cinque Ports with regard to their later custom in respect to forfeiture; possibly alongside Rye, for it is apparent that, when the king granted his right, this right lasted only a year and a day. It is equally apparent, however, that it entailed waste: Ludlow and Rochester belonged therefore with neither Dublin nor the Cinque Ports but were plainly boroughs where the feudal rule of forfeiture prevailed till within a few years of the close of the middle ages, being then modified only to the extent of a transfer of year, day. and waste from the central to the burghal government. These Ludlow and Rochester records are more

${ }^{1}$ Cooper, Cambridge, i, p. 130, a. 1385 . In consequence of two disastrous fires the king granted that the burgesses "should for ever have all fines, . . issues, and forfeitures,...touching any free tenement in the town ... as well before . . . escheators."

${ }^{2}$ Merewether and Stephens, History of the Boroughs, ii, p. 661, a. 1363 . The gift was to relieve the town, and included other issues.

${ }^{3}$ Bateson, Records of Leicester, ii, p. 227.

- Charter of Rochester, p. 16, a. 1460, a grant of "a year and a day, strepp and waste."

"Ludlow" Charters, p. 16, a. 1461. "If any of the burgesses of the town aforesaid . . . shall be convicted for or of felony, or condemned, or outlawed, the same burgesses shall have all the lands and tenements of such . . . for one year and one day after such conviction... and waste and strip thereof, and whatsoever to us . . appertaineth." 
valuable for what they suggest than for what they say, the implication being that the feudal rule in respect to forfeiture was possibly the burghal rule in those drowsy nests of rural conservatism, the smaller and more exclusively agricultural boroughs. Ludlow and Rochester were not alone in this class; the proceedings before the royal justices show that the same condition existed at Shefford, and also that the king might sell the year, day, and waste, thus making his own profit and at the same time some one's else. ${ }^{1}$ At Maldon ${ }^{2}$ the bishop of London, lord of the borough, parted with all his rights in respect to forfeiture for a lump sum from the burgesses. ${ }^{3}$

In the case of treason one would expect to find the king taking forfeited property anywhere, and certainly in boroughs where he took felonious escheat. Forfeitures for treason in London soon after the Barons' War ${ }^{4}$ and in Norwich ${ }^{5}$ during the Wars of the Roses confirm what it seems scarcely needful to prove. When the Normans in England were compelled to make their

1 Curia Regis, no. I6 , m. 6. "The sheriff of Bedfordshire is ordered to inquire in the county court whether a burgage and one-half which Robert le Masscrief (who was hanged for felony) held in Shefford had been (extiterint) in the king's hand for a year and a day, and from whom he held the said burgage and a half, and who now holds them, and who should have (habuerit) the year and day of the lord king." The inquest says that he held them of John, clerk of Shefford, by service of Igd. a year; but they had been in the king's hand for a year and a day, that Warin, son of Gerald, had year, day, and waste by sale of Robert of Thurkelby, itinerant justice in that county, and that the said Warin ought to answer for the same. The inquest also says that W. Bonseriant now holds them by sale of said Warin.

${ }^{2}$ C.P.R., a. $1403, \mathrm{p} .308$.

3 Occasionally a borough seems to have exercised a sort of forfeiture of property for non-payment of the burgage rent. At Dublin in I26r a tenement " escheated" (was forfeited) " to the city for non-payment of landgable for thirty years and upwards" (Gilbert, Records of Dublin, i, p. 93), and in $\mathrm{I}_{262}-63$ the mayor and commonalty of the same city granted a vacant place " escheated to the city for arrears of rent" (ibid., i, p. 95), but this was probably part of the communal property. At times a borough might keep a forfeiture not its own. Hedon, which had kept escheats, retained at least one forfeiture among them (Boyle, Hedon, p. 223).

"C. I. M., i, p. I97: in 50 Henry III " certain houses . . . were taken into the king's hand because W., the king's enemy, last held them."

- Stanley v. Mayor, etc., f. 47: in $\mathrm{I}_{4} 6_{5}$ there was an inquisition in Norwich concerning tenements held by a certain "gentleman, alias attorney: . . . by his attainder by act of Parliament the premises appertain to the king as forfeited." Gentlemen who were also attorneys might be few at that date. 
choice between French and English allegiance the king seems to have confiscated much of the burghal property of those who went; they had become the king's enemies and as such were in a way guilty of treason. For a century and a half such tenements are met with, still retaining the name of 'lands of the Normans.' 1

And now to try to answer the question asked at the beginning of this topic - did forfeiture in the boroughs have the feudal meaning of year, day, and waste to the king, followed by reversion to the chief lord? It apparently did in Ludlow, Rochester, Shefford, and very probably in other small boroughs of the same class. In the Cinque Ports there was no waste, and the same appears substantially true of most of the larger boroughs. Even in the few instances where waste may be implied it can seldom mean the waste of the feudal land law: dominus rex himself would find it difficult to waste the second story or the cellar of a threestory house, each or even a part of which was often a burgage tenement in the larger towns.

In general our conclusion is that while escheat was the chief lord's, except in London and a few other places where there had been so much transfer of realty in the modern way that all lords but the king had been lost sight of, forfeiture was the king's. The rule for the boroughs was that mesne lords lost their right to reversion after year and day; in some indeed perhaps they had never had it. There were exceptions however, such as Dublin and the Cinque Ports, but the latter were exceptional boroughs in other ways as well. In baronial and episcopal boroughs forfeiture was the borough lord's, and in these and other small uncommercial towns year, day, and waste probably prevailed.

'The cause for the course of escheat in London and a few other large cities is the fluidity of burghal realty. This will explain the course of forfeiture also in the same places, but will not suf-

1 R. II., ii, p. 231. At Chippenham in 1279 " juratores dicunt Henricus rex [secundus] . . . dedit ... terre in exotem burgo Willelmo . . . Normanno ... et nunc acciclit domino regi per escaetam ut terra Normannorum."

C. C. R., i, p. 455. At Marlborough in $125^{6}$ the king gave a messuage which was in his hand "as an escheat of the lands of the Normans." Y'robably the lords who forfeited these burgages were aristocratic mesne lords outside the borough rather than actual burgess holders. 
fice to explain it in the many other royal boroughs where this incident is the king's. Perhaps the reason for their custom can best be given by supposing a burgess in some royal borough, say Cambridge about I 250 , to be guilty of felony. He is a freeholder; he holds a burgage tenement. He may be a lineal descendant of him who held it in King Edward's day, but the case is improbable. It is more likely that he, or some not remote ancestor of his, has bought the tenement, that he has no idea nor care who held it in King Edward's day, for population has increased and real property has been divided. He may have bought it outright, though at this period a small rent is often retained, he who retains it being our supposed felon's chief lord. The tenement is now forfeited for felony. To whom, to the chief lord? Where lies his right? He has been paid the messuage's value. To him of whom the chief lord holds, the next mesne lord? What right has he thereto? 'Mobility' has eliminated the mesne lords and the king takes the forfeiture. In the country it is the estate and the tenure which are vital; feudal law knows possession but not ownership. In the important boroughs it is ownership and the person rather than possession and tenure. No one is prominent but the lowest holder, and the king takes the forfeiture just as the state would take it today if the custom of forfeiting a felon's lands and tenements had not been abolished.

\section{Fealty}

Customals, court leet records, and grants of tenements commonly deny the existence of this incident with the feudal definition but affirm it in the burghal meaning. At Ipswich " no landholder of land holden in this Towne by ffree Burgage shall doe . . . fealty to any cheif lord for such tenements," 1 and, with slight differences in the wording of the clauses of their customals, the same is true of Hereford ${ }^{2}$ and Romney. ${ }^{3}$

1 Domesday de Gippewyz, p. I4I; Bacon, Annalls of Ipswiche, p. 34, a. I29o.

2 Johnson, Customs of Hereford, p. 25: "we [i.e., the burgesses] do not use to do fealty or other foreign service to the lords of the fees for our tenements."

${ }^{3}$ Customal of Romney, quoted by Lyon, Dover, ii, p. 320: " no fealty . . . shall be due to no lord of the fee"; as clear as a double negative can make it. 
From the evidence of their customals it is very plain that there was no such incident as fealty in any of these three boroughs, yet at Hereford a record of a plea concerning tenements therein shows that their holder had sworn fealty. ${ }^{1}$ The reference is to the oath to be faithful to the king or lord of the borough and to the borough customs; the fealty whose existence the customals deny is the fealty of feudalism. Every burgess must take this 'burgess-oath' of fealty before the town magistrates once and no more; ${ }^{2}$ feudal fealty was personal and might be exacted often. In the burghal sense, therefore, fealty was sworn at probably every borough in England, ${ }^{3}$ and in most boroughs, or at least in the larger royal boroughs, was probably much the same as at Colchester, where one who would "enjoy the liberties and franchises" must " attend before the Bailiffs for the time being and take his oath to the King and to the town, as Burgesses were wont to do of old." 4 During the first part of our period fealty was sworn only on taking seisin of a tenement for the first time, but that excluded few, as nearly every householder was a freeholder. Toward the close of the middle ages the term burgess applied to many who were not freeholders and all must swear fealty.

In many boroughs, most of which are of the third rank, town records, especially those concerning transfer of tenements, sometimes mention fealty. At Tewkesbury if a non-burgess bought a tenement he was obliged to come to the next court, pay a fine, and swear fealty. ${ }^{5}$ At Birmingham after the plague a free burgage by fealty is said to have grown up with an oath to observe

1 Madox, Firma Burgi, p. 257: "pro quibus tenementis W. . . fecit fidelitatem," 6 Fid. II.

${ }^{2}$ Bateson, Borough Customs, ii, p. 84: the juratores " dicunt quod burgenses postquam semel fecerint fidelitatem" need come no more to court to swear fealty on account of other tenements which they have bought.

3 The Torskey customal affords a sample burgess-oath from a small borough. At that town the burgesses " dicunt quod quando aliquis faciet fidelitatem dornino, debet eodem tempore jurare quod debet sustinere, defendere, et manutenere libertates, consuctudines, et usus ville et consilium suum celare pro posse suo" (Batteson, Borough Customs, ii, p. 84).

- Benham, Red Paper Book of Colchester, p. 79, a. 1452.

s Bennett, Teukesbury, pp. 323-324. 
the customs and services of the manor. ${ }^{1}$ This incident was due also at Whitby, ${ }^{2}$ Doncaster, ${ }^{3}$ Durham, ${ }^{4}$ Exeter, ${ }^{5}$ and was sometimes noticed in grants at such boroughs as Colchester ${ }^{6}$ and London. ${ }^{7}$

In some of the baronial or ecclesiastical boroughs fealty had more of a feudal meaning or at least a feudal sound. At Weymouth it appears to have been vicarious, the elected town offcials swearing fealty to the borough lord ${ }^{8}$ a proceeding which seems to have meant little more than the swearing in of newlyelected town officials means today. Even though it should, the fealty they did was not an incident of the tenure, and there may have been less fealty sworn at Weymouth than at almost any other town, certainly less than at the even humbler borough

1 Mrs. J. R. Green, Town Life in the Fifteenth Century, i, p. 200, note 2.

2 Atkinson, Whitby, p. 321 .

3 Hardy, Records of Doncaster, ii, p. 20; Tomlinson, Doncaster, p. 28, note. As usual it was sworn only on taking up messuages. Where his wife is an heir the husband swears fealty for her: " $\mathrm{O}$. H. does fealty for two messuages . . . late W. M.'s, in right of his wife" (Hardy, Records of Doncaster, ii, p. 20, a. I 506).

4 Hutchinson, History of Durham, ii, p. I2, note. The burgages were held by fealty and suit at the borough court.

${ }^{5}$ C. I. M., Henry VII, i, p. 389. Half a messuage was held of the mayor and bailiffs by fealty only. 9 Henry VII. In Kenfig in I400 a burgage is held by "redditus et servicia" and a specification "de jure consueta," probably fealty (Clark, Cartae Glamorg., iv, pp. 307 f.).

${ }^{6}$ C. I. M., Henry VII, i, p. 208. A messuage is "held of the prior of St. Botolph's, Colchester, by fealty." 5 Henry VII.

7 Madox, Firma Burgi, p. II8. A tenement whose holder had been attainted "tenetur de Domino Rege ut in libero burgagio . . . per fidelitatem." 28 Henry VIII. It may be asked whether some of these records do not refer to fealty to a lord, for the phrase ' held by fealty' certainly has that sound. It is easy to settle the point from the evidence of the London records of transfer of property; there are thousands of them in existence and they show that the fealty referred to was only the burgess-oath. At Colchester messuages ( C. I. M., Henry VII, i, p. 208) were held of the prior of St. Botolph's; the fealty due from their holders was sworn to the town of Colchester and to the king, lord of the borough. The chief lord of the messuages in the London citation (Madox, Firma Burgi, p. I18) was the city. Even communal property was forfeited to the king.

8 Moule, Weymouth, p. I6. In $125^{2}$ the prior of St. Swithin's at Winchester gave certain privileges to his burgesses of Weymouth, among them "that all bailiffs or officers of the said borough . . . may be chosen by the burgesses... and ... shall yearly ... be presented, who to us . . . and our church . . : shall do fealty." 
of East Grinstead. ${ }^{1}$ At Manchester one who acquired a tenement by inheritance, and probably any non-burgess who bought a burgage, must swear fealty before the lord's steward, ${ }^{2}$ and this under the last Tudor. At East Teignmouth ${ }^{3}$ and Stokecurcy fealty was owed, though in the latter borough it seems to have been due the Earl of Northumberland, warden of the castle of Stokecurcy, the messuages in question, though within the borough bounds, lying in the fee of the castle. ${ }^{4}$

In these little fishing or farming villages the burgess-oath may not have been quite the same as in other boroughs. 'Though it gets a feudal tinge from being taken before the lord's steward, the main difference between it and the usual burgess-oath is in the implication that it said nothing of allegiance to the borough, a condition which, if true, need surprise no one, especially in the backward boroughs between Ouse and Trent. On the other hand it would seem that to a dweller in one of the older and larger communities the most important part of his oath was that in which he swore to be faithful to his borough; the king was far off, personal knowledge of him was rare and often not desirable, and burghal jealousy ran high. Burghal fealty in the earlier part of our period was a tenurial incident, an obligation sworn only at acquisition of real property: the fealty of feudalism was far wider and was not a tenurial incident.

1 Hills, East Grinstead, p. Io. The burgesses held "by fealty only and suit of Court."

${ }^{2}$ Court Leet Records of Manchester, i, pp. 104, 167, 231-233 et seq. : " ad hanc curiam venit . . II. P. coram R. H. senescallo ibidem, et juratus est domino" (p. 167 ).

${ }^{3}$ C. I. M., Henry VII, i, p. 364 . W. of Exeter held messuages " by fealty only, for all services." 8 Henry VII. The fealty was due the bishop of Exeter, lord of the borough. There were other services however; the holders owed rents to other lorels but not to the lord of the borough. In West Teignmouth the same phrase is used regarding tenements held of the dean and chapter of Exeter.

4 C. I. M., Henry VII, i, p. 294. (For tenements on castle-lands see p. ro3.) "Twclve burgages in the borough of Stokecurcy . . . held of the carl of Northumberland, as of the castle of Stokecurcy, by fealty and $12 \mathrm{~s}$. rent yearly." It is an open question whether fealt $y$ were due the town in this case, though the probability is against it. The fact that the Earl was lord of the borough would render the destination of fealty the same in any case. 
Naturally the fealty of the boroughs had something in common with the fealty of the country, burgess and knight or socager swore to be faithful, but then came the difference; though any freeman might be called on to swear fealty to the king, such was only an oath of allegiance; his fealty was due also to his immediate lord. An oath of the latter sort would be preposterous in the boroughs. To whom was a burgess to swear it? In most cases the chief lord of a tenement was a burgess like unto himself; indeed he might rank much lower in the social scale. Fealty sworn to such would be meaningless. In London the bishop of Ely held tenements of Henry the Carpenter: shall a bishop swear fealty to a carpenter ? ${ }^{1}$ Feudal fealty, like forfeiture, cannot live alongside mobility. ${ }^{2}$

Yet the less of feudality there was in connection with the tenure the more likely was the term fealty to appear in connection with the title to real property, and many messuages are 'held by fealty only.' The explanation however is very simple. At any time during our period, though especially in the later part, messuages were transferred by simple sale, no rent being reserved by the seller. The theory of the law is possession, he who holds of no one else holds of the king; the holder has taken or must take the burgess-oath, therefore ' he holds by fealty,' for there is nothing else for him to hold by.

\section{Homage}

In feudal speech this incident is commonly connected with fealty, ' homage and fealty.' It has been shown that the fealty of the boroughs differed from the fealty of feudalism; for homage there was no place at all in the boroughs, though the name sometimes occurs in such backward places as Manchester and Stockport, where it is used in a way which makes it appear almost to a certainty to be only another name for fealty. With respect to most of the feudal incidents customals of early compilation are

1 C. I. M., ii, p. 478 , I8 Ed. I.

${ }^{2}$ Manchester and other small places of that sort either retain a very archaic nature, or have never acquired a purely burghal character. They have the oath before the lord's steward (they are all baronial or ecclesiastical boroughs), the dagger as heriot, and relief which was much the same. 
silent; such incidents were unknown. In some customals of later compilation they are noted though only to be denied. As regards homage, there seems to be only one important borough in England whose burgesses considered it worthy of even repudiation. ${ }^{1}$

The charter to the burgesses of Manchester says nothing of homage, but it occurs in legal records of that borough, ${ }^{2}$ though not often; when used, however, there is no word of fealty, which leads one to think that it is only another name for that incident. At Stockport homage is used in the same way as at Manchester. ${ }^{3}$ The two places had the same customs almost to a word in such matters as arms-relief or heriot; in Manchester fealty is commonly found, and at times homage. At Stockport homage may be the favorite term, but apparently in both places it is fealty alone that is owed." There are a few boroughs, most of which are of even less importance than Manchester, where homage occurs in a few grants, not from the lord of the borough to a burgess, but from one burgess to another, from father to son, or from mother to daughter. All that the lord of such a borough ever asked was that the grantee should pay his rent and attend the borough court as a suitor at the proper periods, while all the other records of transfer in these places contain nothing as to any incidents whatever. It seems that the homage of these grants means just nothing at all, its intrusion being due to ignorant imitation of the feudal nomenclature of grants and releases of the country, a nomenclature which the older boroughs did not use as they had long before developed transfer formulas of their own. ${ }^{5}$

1 Domesday de Gippeayz, p. I4r; Bacon, Annalls of Ipsaiche, p. 34: " no landholder of land holden in this Towne by ffree Burgage shall doe homage."

2 Court Lect Records of Manchester, i, pp. 42-43.

${ }^{3}$ Heginbotham, Stockporl, i, pp. $\mathbf{1}^{62-163}$. In the matter of a tenement in Stockport the leet jurors said "that T. 13. . . is Burgess for one burgage . . and he did homage " on taking up the tenement.

"These court leet Records are from the latter half of the sixteenth century. Accuracy in the use of feudal nomenclature is not to be expected therein.

'It may be that the 'homage and service' of these grants means much the same as good will and amity. Du Cange treats 'homage and service' as a villein incident due the lord; it cannot mean that in these cases. Temp. Edward I a burgess of Hardness (I)artmouth) grants to his son and his son's wife "part of his 


\section{Military Service}

The incidents so far considered are, in name at least, closely connected with feudalism, and with the exception of homage and fealty are only those known as the feudal incidents. ${ }^{1}$ At

tenement" "for his son's homage and service" (H. M. C., Rep., 5, p. 6or). Three other contemporary grants use the same expression (ibid., pp. 599,600), each of the grantors being a burgess, as other records show. There are many other grants in the same borough but they say nothing of homage. The lord was Gilbert Fitz-Stephen, lord of Norton; all he required in the many grants which he made at this time was rent and suit of court (see ibid., pp. 598-599).

About 1200 in Wells one burgess conveyed his land to another for his ' homage and service' (H. M. C., Rep., iii, p. 360). The other grants in the same borough do not use this form, and even in the conveyance instanced it appears that the grantee's whole service consisted in a payment of ros.

In Leicester one burgess released to another " the homage and service of Robert the Leech, due for the tenements" (Bateson, Records of Leicester, i, pp. 381-382); the rents of the tenements are given and the quit-claim is paid for; the whole thing seems to be of the same nature as the verbiage and redundancy, so impressive to the ignorant, of many modern legal documents. In the same borough at about the same time (c. I250) a 'vilen's daughter' released to a burgess her right in a piece of land " with homages . . . accruing from the land" (ibid., p. $3^{8} 3$ ). These releases are mostly sales, sometimes of the tenement, sometimes of its issues.

At Durham one burgage is said to be held by homage and fealty; homage is probably used to strengthen fealty (see Hutchinson, Durham, ii, p. I 2, note) like the ' give, grant, and quit-claim forever' of burghal deeds.

In the Waterford customal (according to Miss M. Bateson, Borough Customs, ii, p. 84), was this odd provision: " if . . . the mayor or a citizen buys land in fee to him and his heirs, beware that his charter does not say that he is enfeoffed by homage and service, for if he be enfeoffed by homage and service, wardship and marriage will be due." Suppose he did not 'beware' and his charter (conveyance) called for homage and service. How and by what court could the claim to wardship and marriage be enforced? The charter to Waterford, following the BristolDublin customal, stated distinctly the absence of these incidents; even when a citizen (of Bristol or Dublin) held fiefs in the foreign his holding under a tenure which knew neither incident protected him. That marriage and wardship often were the subject of private contracts is true (as at Bridport, temp. Ed. I, a grantor required "aid, counsel, and marriage" of the grantee - H. M. C., Rep., 6, p. 480) but this has nothing to do with any tenurial custom. In some boroughs such a contract in respect to a minor heir was forbidden (Lyon, Dover, i, p. xlv) Private contracts, of course, would be enforced by the courts, but such a proceeding as the above savors more of fraud than mutual contract. If the clause should refer to acquisition by a burgess of land in the foreign then it is easily understandable, but why should a customal intermeddle in a matter where the borough court had no jurisdiction?

1 Heriot, where found, is really relief; where it consists of arms it is in a class by . itself. 
a few boroughs in Ireland and Wales there were other conditions infrequently superimposed on rather than joined to burgage tenure which gave it a semi-military aspect. Thus at Limerick King John, while giving burgages, connected with each a number of knights' fees ${ }^{1}$ in the foreign, though he did not insist that the connection should endure. When, however, the Earl of Lincoln founded Denbigh in North Wales he granted the burgages with the distinct condition that each tenement should be forfeited if it did not maintain an armed man to defend the walls of the borough. ${ }^{2} \quad$ These military features were, however, special considerations superadded to the tenure to meet special conditions, which, when removed, and Welsh and Irish conquest did remove them, left the tenure the same as in any ordinary borough. ${ }^{3}$

\section{RETRAIT FÉODAL}

It is peculiar that an incident which all other tenures of land in England rejected ${ }^{4}$ should be found in connection with the boroughs, whose tenure was freest of all. It is difficult to account for its presence in the few boroughs where it existed, for if due to the intrusion of a foreign element it should be found where there is no trace of it, in those little boroughs which had distinctly Norman customs.

At Northampton when a tenement was to be sold the customal states that the chief lord should have the right to purchase it before any one else if there were no heirs, or if the heirs refused to buy. ${ }^{5}$ The customal goes on to state that if such a tenement

${ }^{1}$ Lenihan, Limerick, p. 48 , $a$. I 200 . To " G. one burgage below the walls of Limerick," to another burgess (? knight) four burgages, and so on; in all nine burgages to six men and with each burgage three to five knights' fees.

${ }^{2}$ Williams, Denbigh, pP. 302-309, a. $1283-90$. The charter itself contained the grant to each burgess by name of "one burgage in Denbigh within the walls ... to have and to hold to them, and to their heirs, and to their English assigns " on condition that each " shall find a man armed in the aforesaid town of Denbigh . . . to guard and to defend the aforesaid town for each burgage."

${ }^{3}$ As stated before all the Anglo-Norman boroughs of Ireland were more or less of the nature of garrisons.

- P'ollock and Maitland, IIistory of English Law, i, p. 648.

- Markham, Liber Custumarum, p. I8: The next of kin "shall be moste nexte to aske the cate [purchase] than any man ellis, or the chefe lorde if ther be no 
is sold, the lord not being given a chance to buy, he may come to court within the first four pleas (probably four weeks at Northampton) after the sale, give the buyer what he paid, and take the tenement. If the sale were made out of court so that the lord knew nothing of it, he should have a chance to recover the tenement as soon as the sale was shown, while to avoid fraud both buyer and seller must take oath that the price for which the messuage is said to be sold was that really paid. The chief lord had no negative voice on a sale which was said to be made under the stress of poverty; ${ }^{1}$ the excuse of poverty was often used. The limit of time within which a lord might exercise his right of preëmption was a year and a day, and the year and day began to run only from the time when the lord came of age, if a minor, or got back to England, if a traveller, or out of jail, if a prisoner. $^{2}$

This incident is found in a modified form at Norwich, where, however, it applied only to special cases of devised tenements, ${ }^{3}$ and was consequently about as feeble a right of retrait as can be thought of. In brief it was this: the lord had a right (after the kin) before others to purchase a tenement which must be sold anyway under the terms of a last will. ${ }^{4}$ It is possible that the lord's retrait may have existed in Gloucester, but the evidence therefor is slight, and instead of proving the presence of retrait féodal goes rather to show a burgess's fear of his wife and his

man of the lynage. And if the chefe lorde take the sales [i.e., alienation fee] be he forbarred of the cate."

1 Ibid., p. I9: if one is compelled by poverty to part with his tenement " the chefe lorde shall not in no maner wise letten [i.e., prevent]."

2 See Markham, Liber Custumarum, pp. I7-I9 for the custom. Be it noted that he who had the right of preëmption was the chief lord.

${ }^{3}$ Hudson and Tingey, Records of Norwich, i, pp. 156-157, I59-160: "Also if it happen that such a devisee decease without issue," the reference being to an entailed estate, issue failing, " let the tenement thus devised . . . be delivered to the next heir of the testator ... for a certain price. ... And if he refuse let it be offered . . . to the lord of the fee" before being sold. Testator and chief lord are not one and the same person.

4 This is rather the ghost of retrait féodal than its living substance. Possibly the lord's right of preëmption had once been of more effect in Norwich. 
lord the abbot. ${ }^{1}$ At Whitby, ${ }^{2}$ Exeter, ${ }^{3}$ and Walsall ${ }^{4}$ there is no doubt of the reality of retrail féodal. The incident at Whitby ${ }^{5}$ was due the lord of the borough, elsewhere it was the right of the chief lord, who in such a borough as Northampton, the only place of importance where its existence is certain, was most likely to be a fellow-burgess. Even in Northampton it is unlikely that the lord's right was often exercised; it came after the kin's right to preëmption and was barred by the lord's taking an alienation fee ${ }^{6}$ the latter an incident whose incidence is far wider than the custom, for which it may at one time have been a commutation.

\section{Alienation Fees}

The usual name for such fees, which were paid to the lord in a few boroughs, ${ }^{7}$ was ' sellings.' At Northampton this fee was

1 Stevenson, Records of the Corporation of Gloucester, p. 73: "Grant from . . . with the assent of his wife and the consent of his son . . . and of Thomas Carbunel Abbot of Gloucester, his lord, . . . of a messuage." If this were a constant or even a frequently recurring condition in grants at Gloucester it would, of course, prove the existence of the lord's retrail. It seems however to be found in this conveyance alone. See ibid., pp. 70, 72, 82 .

${ }^{2}$ Atkinson, Whitby, p. 284 (cir. a. I 185 ): "si quis autem terram suam vendere voluerit, primitus hoc abbati ostendere debet, et ei terram, si eam emere voluerit, vendendam offere pro tali rationabili pretio quale alius ei pro eadem terra dare voluerit. Si vero eam emere noluerit, consilio et consensu ejus eandem vendat."

${ }^{3}$ Bateson, Borough Customs, ii, p. 6r: "If one man holds a tenement of another by service, he may sell it, saving the lord's right, and if he sells it unconditionally .. . by law the lord has a better right than another [to buy it]." Miss Bateson gives the same custom for the 'borough' of Tettenhall Regis, but it is doubtful if the place were ever a borough (see Samuel Lewis, A Topographical Dictionary of England, 7 the ed., 1848, iv, p. 317).

At half-lurghal, half-manorial Kingsthorpe the 'franche men of the town' might cxercise retrait when land was sold to a non-resident (Glover, Kingsthorpiana, p. $x \mathrm{l})$.

- Charter of Walsall, a. 119\$-1216: Fe salvo mili et heredibus meis quod si quis dictorum burgensium burgagia sua vendere voluerit monstrabit nobis vel ballivo nostro, Fit si sit ad opus nostrum habebimus dicta burgagia de duodecin denariis minus quam aliquis alius.

For this section of the Walsall charter I am indeleded to Mr. Adolphus Ballard, author of Domesday Boroughs, etc., who courteously communicated it to me in advance of the publication of his British Borough Charters, 10.42-1216 (1913).

I'ssibly at lixeter also.

6 Sec Markham, Liber Custumurum, p. 18 .

7 Alienation fees ats paid to the borough will be considered under 'Mubility'; see [. 128. 
due the chief lord at the sale of a messuage; ${ }^{1}$ the customal, however, does not state the amount. In the boroughs where it existed it was commonly a small fixed sum. At Preston ${ }^{2}$ this fee must be paid by him who sold a tenement, though only when he had but one. It is possible that this remission of the fee to a holder of more than one tenement was because he was still a householder and was therefore unlikely to become an emigrant, though it would seem that $4 \mathrm{~d}$. would not be a material obstacle to his leaving.

At Whitby one who bought a tenement paid a fee, probably to the abbot, lord of the borough, and a small contribution for beer as well; ${ }^{3}$ at Tewkesbury ${ }^{4}$ a fee must be paid by incoming buyers of messuages. ${ }^{5}$ At Manchester, Stockport, and Salford fixed alienation fees were customary, ${ }^{6}$ and must be paid in the two latter towns not only when a tenement was sold but also when it was devised. ${ }^{7}$ At Bury Saint Edmunds an aliena-

1 Markham, Liber Custumarum, p. I8: " if the chefe lorde take the sales."

${ }^{2}$ Hardwick, Preston, p. 260; Fishwick, Preston, p. I6: "when it [i. e., a tenement] shall be sold and he [i.e., the seller] hath not another burgage, when the other shall be seized he shall give $4 \mathrm{~d}$. from the issue, but if he hath another burgage he shall give nothing."

${ }^{3}$ Atkinson, Whitby, p. 284: "emptor vero terrae consuetudinem ad saisinam iv denarios dabit, et i denarium burgensibus ad beverage."

"At Tewkesbury and Cardiff one was allowed to take up an inherited tenement "without having to give notice to the bailiff or prevost." See Matthews, Cardiff Records, i, p. I2.

5 Bennett, Tewkesbury, pp. 323-324. When a non-burgess bought a tenement he must come to the next court and pay a fine.

6 Tait, Mediaeval Manchester, p. 66; Whitaker, Manchester, p. 585. At Salford "quicunque burgagium suum vendere voluerit . . . et a villa discedere, dabit mihi 4 d. et libere ibit quocumque voluerit." At first sight the fee of $4 \mathrm{~d}$. seems to be a payment for permission to leave the town, for vendere and discedere stand, as it were, opposed to dabit and $i b i t$, while the Preston practice of excusing the seller from payment when he had another burgage, and therefore could not go, certainly does not weaken this view. There is probably nothing in it, however. When these towns were chartered in the latter part of the thirteenth century $4 \mathrm{~d}$. would be a small restriction on going or staying. It was only a custom of Breteuil.

7 Tait, Mediaeval Manchester, p. 67. Bequest was lawful at these places only when a burgess had no heir. He might then devise his messuage "Salvo tamen jure meo, scilicet quatuor denarios." The saving clause is not found in the Manchester charter. Professor Tait (ibid., p. 69) suggests that it may be covered by the servicium salvum of that grant, but this is carried out in the Stockport charter and is a prohibition of devise in mortmain: "salvo servicio ad ipsum burgagium pertinere, 
tion fee was due when a few of the messuages changed hands, being payable only from 'tenements of hadgovel'; that is, from original tenements. ${ }^{1}$ This fee was customary at Leeds, ${ }^{2}$ Pontefract, ${ }^{3}$ where it was exacted from both buyer and seller, and Maldon ${ }^{4}$ where the fee took the modern aspect of a percentage of the price.

There are other boroughs where alienation fees existed though they did not go to a lord, and still others where the customs, if ever known, had been forgotten or had become a fee accompanying seisin. . For instance at Hereford in 1086 one might sell his house if he wished to leave the city, the third penny being the bailiff's, ${ }^{5}$ but when the customal was drawn up in $1280-8 \mathrm{I}$, sellings as such had disappeared. ${ }^{6}$

ita sc. quod illud burgagium non alienetur in religiosa." This clause occurs in each of the three charters in regard to sale of tenements. It seems that if one should take the charter as it stands the conclusion must be that at Manchester he who acquired a tenement by will paid no sellings. It is a trivial matter anyway; devise was very rare at Manchester.

1 Arnold, Memorials of St. Edmund's Abbey, iii, p. 307: " every one who purchases a tenement of Hadgovel shall not owe the Abbot for entry into the said tenement more than 20 sous and one purse of Id. rob. and shall be quit of tax . . and of every kind of purchase, without paying anything for entry into the tenements of that fee, by the payment of the first 20 sous." The original messuage seems to have been regarded as a head tenement or capital messuage. This is from the unconfirmed charter of ${ }_{1327}$, but the townsmen were not likely to demand that sellings be taken, though they may have been trying to curtail them. Town government however and not tenure was in dispute.

${ }^{2}$ Wardell, Leeds, app., p. iv.

${ }^{3}$ H. M. C., Rep., 8, p. 269: a seller of land " dabit unum denarium de theloneo, et pretor [? pracpositus] dabit terram emptori, . . . et emptor dabit similiter unum denarium."

"C. P. R., a. 1403 , p. 308 . When the bishop of London sold his customs in Maldon to his men of Maldon among them was one called "Landchepe, viz., taking from each man or woman purchasing land within the town rod. on each mark of purchase," $6 ! \%$. This sort of fee was taken by certain boroughs.

s D. B., i, f. гzga.

- In a few boroughs the customal guarded against a lord's taking an alienation fee, as at Castle Rising, where the burgesses may " sell . . . their burgages to whom they will without any gainsaying," etc. (Parkin, Lynn, p. 205); and at Bakewell, where they may "sell . . their burgages . . to whom they will . . . without the leave of himself," i.e., the lord (H. M. C., Duke of Rutland, iv, p. 41 , a. I 286). 


\section{INPENNY AND OUTPENNY}

In some cases this is only 'sellings' under another name, in others it is additional thereto, but as those who got and those who paid called it an entrance or a departure fee it seems as well to retain the name. ${ }^{1}$ In Wake's charter to Chesterfield ${ }^{2}$ this fee was saved to the lord of the borough. The theoretical difference between this fee and sellings seems to be that the latter commonly applied to any sale of property, this custom only to sales made to foreigners, but the amount, $4 \mathrm{~d}$., reminds one of Manchester and places of that sort. The distinction is apparent at Preston, ${ }^{3}$ where both fees existed side by side. At Shaftesbury in 7 Henry VI an entrance fee was paid to the abbess, to whom (hardly the same abbess) the farm had been granted in $1283 .{ }^{4}$

These alienation fees as paid to a lord are fixed ${ }^{5}$ and very small, and appear at only a few boroughs, most of which, Northampton excepted, are baronial, created, and of little or no size or importance. At Northampton the chief lord is their receiver, elsewhere such fees are undoubtedly the perquisite of the lord of the borough. Apparently they are the result of imitation of some typical burghal custom, very probably that of Breteuil. also.

${ }^{1}$ Only as paid to a lord will it be dealt with here. This fee is due to boroughs

"Yeatman, Records of Chesterfield, p. 39, 22 Ed. I: " the other children " (than eldest sons) when "each one shall acquire to himself a Burgess part . . . shall, upon entering upon it, give me and my heirs 4 d." And again (ibid., p. 4o) "no stranger shall purchase a burgage or have seisin before that they [sic] satisfy myself or my heirs or my bailiffs"; the two sorts of fees, in one sense.

${ }^{3}$ Hardwick, Preston, p. 259: "If any one wish to be made a burgess, he shall come into court and give to the mayor rad., and shall take his burgage from the mayor." The inpenny went to the borough in this case, the sellings to the borough lord.

"Mayo, Records of Shaftesbury, p. 23. At the court leet a fine of 4d. was made "for entering upon a $\mathrm{a}_{\text {s }}$ cottage." The fee was not always $4 \mathrm{~d}$.; in the same year a capon was paid as a fine for entrance upon "three roods of pastureland " (ibid., p. 23).

As an illustration of the desire to prevent burgesses from leaving a borough, in 1274 the justiciary of Ireland granted burgages "pertaining to the king " in Rendon on condition that the grantees shall "dwell there, and do not withdraw from the king's fealty " (C.P.R., a. I274, p. 57). At Dunheved no burgess might depart from his worst holdings and keep his best (Peter, Launceston, p. 174).

${ }^{5} 4 \mathrm{~d}$. as a rule; at Maldon, a borough with different customs, $6 \frac{1}{4} \%$. 
At Northampton the lord of the borough, the king in this case, would be entitled to his fee only when a tenement was sold which was held directly of him; in most cases this would be merely the fragment which represented an original messuage. The chief lord, who got the sellings, was most likely to be a burgess. As to an entrance fee, that, where it existed, was apt to become a perquisite of the bailiff or town-clerk for witnessing the seisin and enrolling the deed. ${ }^{1}$

\section{Suit of Court}

At a few small boroughs the burgesses owed suit at the lord's court as an incident of the tenure. The charter to the men of Bideford provided for suit at the baron's court, ${ }^{2}$ and at Dartmouth, where the lord of Norton made his borough as it were piecemeal, his separate grants of burgages required attendance at his court. ${ }^{3}$ Suit of court is owed at Inchcoyn, ${ }^{4}$ Durham, ${ }^{5}$ Manchester, ${ }^{6}$ Doncaster, ${ }^{7}$ Charmouth, ${ }^{8}$ East Grinstead, ${ }^{9}$ and Stockport. ${ }^{10}$ This suit of court is distinctly intrinsec and not forinsec service; it is obtained by contract and is not an obligation of the tenure. The same is true of military service, ${ }^{11}$

1 This is not to be taken as implying that fees for recording deeds sprang from alienation fees.

2 Watkins, Bideford, p. ז3, probably temp. Henry 111 .

${ }^{3}$ II. M. C., Rep., v, p. 599. See ibid., pp. 598-601: "such suits of court as the other freemen make." These were two suits a year. Most of the grants are temp. IIenry III and Edward I.

4 Caulfield, Ionghal, p. xxxv, a. I 285: "The burgesses of Inchicoyn hold three cor. of land in their borough tenures at New Town, at $\mathfrak{L}_{1 \mathrm{r}}$ I + s. yearly, and suit at their Hundred."

- IJutchinson, Durhum, ii, p. 12, note. Three suits a year are required; the court may have been the portmanmote and not the lord's court.

' Court Leet Records of .1T anchester, i, p. 204 (16th century).

7 Hardy, Records of Doncaster, ii, p. 20, a. 1506.

${ }^{8}$ C.I. M., Henry VII, i, p. I $+1,3$ Henry VII: " three burgages in Charnenouth .. held of the Abbot of Ford . . by 2 s. yearly rent and suit of court ... twice yearly."

9 Hills, East Grinstead, p. 10 (Sussex). In 1559 there were 48 burgages and 24 cottages; the burgesses held by "fealty only and suit of court."

${ }^{10}$ Ineginbotham, Stock port, i, p. I63, a. 16,1: "suite and service" are demanded from the buyer of a tenement. If Middlewich in Cheshire were a borough in the middle ages (it is not today) it should be added to those named above.

11 See P. $5 \mathrm{I}$. 
and of gite, which was owed by at least one tenement at Liverpool. ${ }^{1}$

A few boroughs became their own lords during the middle ages by buying out or paying a lump sum for their fee-farm rents. ${ }^{2}$ In 8 Henry VII messuages in Bristol are " held of the Mayor and Commonalty of Bristol in free burgage as all Bristol is held," 3 and in such a case even the name of a personal lord vanished from the tenure.

\section{SUMMARY}

At this point a brief recapitulation of the principal boroughs in which the tenure was affected by incidents with feudal or villein prototypes or antitypes may be not amiss. Following the order in which the subject has been treated in this chapter, it appears that of the three aids only two, those taken at knighting and marrying, were known, and these at but one unimportant borough - Castle Rising. Marriage had no place anywhere, and feudal wardship did not exist. Relief however was owed at several boroughs, the most important of which are Northampton and Leicester; the other towns where it was an incident, as Manchester and Denbigh, are mostly created boroughs, and many of them show foreign influence in their customs. Heriot was confined to the same group of created boroughs and was never a best chattel, but was rather of the nature of the heriot of Canute's law.

Fealty in the feudal sense, and homage, which as used seems to have been only another name for fealty, are found only at Manchester and two other little boroughs of like sort. In a few garrison boroughs, as Limerick and Denbigh, a small amount of military service must be done. That stranger or outcast, retrait féodal, appeared in Exeter, Northampton, Norwich (in narrow limits), and Whitby. In the first borough and the last

1 Picton, Liverpool Records, i, p. I2, a. I346. There was one messuage which finds " a stable for twelve horses at each arrival of the Lord within the said borough," an impossible condition with an ordinary town tenement.

2 In the modern period most of the larger boroughs bought their fee-farm rents. For instance, in the 17 th century the Liverpool corporation became "lords of the manor" by purchase (Picton, Liver pool Records, i, p. 582).

${ }^{3}$ C. I. M., Henry VII, i, p. 327. 
it was probably due to a foreign founder, in the others to foreign immigration.

A few incidents common to both feudalism and villeinage were more wide-spread, but, like relief and heriot, alienation and entrance fees (as paid to a lord) were known, with few exceptions, of which Northampton is the chief, only in the same group of created baronial boroughs. Suit at the lord's court was an intrinsec incident of the tenure at a few small baronial boroughs in Ireland, the southwest of England, and between Ouse and Trent.

With the exception of Northampton the tenure in the important boroughs, practically all of which are royal boroughs, had no lordly incidents whatever, feudal or villein, with the exception of fealty. This, however, was neither villein nor feudal in the true sense, but was merely an oath to be faithful to the borough and its lord, and soon became a personal rather than a tenurial obligation. 


\section{CHAPTER II}

\section{BURGAGE RENTS}

THE term burgage rent is here used to mean the rent of assize, fixed, or fee-farm rent which each messuage or burgage ${ }^{1}$ must pay to the lord of the borough, and which endured while enough of the tenement remained to be recognizable. It might be divided as the messuage was divided or might remain as a perpetual rent on that part from which alienations had been made. Both methods are found in operation in the later middle ages. ${ }^{2}$ This burgage rent varied greatly in amount, even in the same town. In the older boroughs it was often Id.; in many of the boroughs created by charter it was a uniform rent of $12 \mathrm{~d}$.; in one of these, Agardsley, it was $18 \mathrm{~d}$. Whatever the sums, they seem very low at any period when compared with the renting values of the tenements, while time soon made a shilling rent look very small and a penny rent a mere symbol. In fact that is just what these penny rents, the rents of the messuages in many of the older boroughs, seem to have been at any time - mere symbols of lordship. In such places this rent was the only tie between lord and land, fealty the only bond between lord and man. Does this not seem to have originated as a mutual arrangement between man and man to produce lordship and vassalage ?

The main theme of this chapter will be these burgage rents, their amounts and form, with illustrative tables to facilitate comparison between the original rents and the selling and renting values of the messuages, as well as other conditions thereto relating. Before these matters are taken up, the details of

1 Except in the founded boroughs the former was the term for an urban tenement in mediaeval England; 'burgage' referred to the tenure.

2 With the close of the mediaeval period original or quit-rents had begun to drop away as they were not worth collecting, in many cases because the tenements which owed them had disappeared. A few of these rents remain to the present day. 
burghal nomenclature need mention and definition. When a borough owed its origin to a charter, the usual formula thereof was "so many pence from each burgage or messuage," and no name but rent or rental appeared. Other names were in vogue, however, which had their origin in the older boroughs: gavel or gable, landgable, hawgable, housegable, and many variants of these.

\section{LANDGABLE AND HAWGABLE}

Gable alone was sometimes used for the burgage rent. At Scarborough it seems to be the only name for the fixed rent; ${ }^{1}$ it was used also at Wallingford ${ }^{2}$ in the twelfth century and at Chester ${ }^{3}$ from the eleventh to the sixteenth and probably later centuries.

As, however, 'gable' was occasionally used with other meanings, the fixed rent on land or houses, or both, was commonly called hawgable or landgable. The late Professor Maitland was of the opinion that hawgable was paid for the houses, and landgable for the arable strips in the common fields. ${ }^{4}$ This may have been the case at an early date, possibly in other places than Cambridge, whose local usage was the cause of the great scholar's suggestion; though in nearly every borough the distinction was

1 See Brown, Forkshire Inquisition, i, pp. 22, 164, and iii, pp. 91-93: a. 1250, 3 Ed. I, a. 1298.

${ }^{2}$ Cir. 1156 Henry II remitted his gable to the burgesses, ... "de annuo Gablio meo, quod solebant reddere de Burgo Wallingford, de eo, scilicet, quod ad me pertinet in Burgo" (Hedges, Wallingford, i, p. 27 I); gablium almost certainly refers to the burgage rent. The last clause seems to be to save the interests of other lords than the king.

When in 1253 Simon de Montfort remitted 'bridge-silver and gavel-pence' to his burgesses of Leicester, the latter are probably the fixed rents; they amounted to only $5^{6 \mathrm{~s}}$. 8d., and were unequal, a condition to be expected. (See Thompson, Leicester, p. 70.)

At Farnham, however, in the thirteenth century "G. et H. et R. praepositus reddunt compotum ... de toto gabulo assiso de Huppel[anda] (upland) ... et . . vii l. de firma burgi" (Hall, Pipe Roll of the Bishopric of Winchester, 1208 -09 , p. 37). The term in this case certainly does not refer to the burgage rents, which would be contained in the farm.

3 D. B., i, f. 262 b; H. M. C., Rep., 8, p. 362: "Hereafter foloith the Gabul Rentes "; from the Assembly Book, a. 1533.

- Tounship and Borough, p. 70 . 
lost before the 'Great Inquiry,' ' and even in Cambridge it was not always adhered to ${ }^{2}$ the term sometimes being applied there to the rent of land alone, ${ }^{3}$ while in many borough it was unknown at any period of our subject. The Hundred Rolls specify about two hundred houses as liable to hawgable, the amount of which in the fifteenth century was $£_{7} 2$ s. $\frac{3}{4} \mathrm{~d} .{ }^{4} \quad$ By this date the hawgable had become a ' high gable,' thought to have something to do with the gables of houses. A few high gable rents were paid the Cambridge corporation as late as 1853 , and may be even today. ${ }^{5}$

The term hawgable was used in other boroughs than Cambridge, not, however, side by side with ' landgable,' but to its exclusion. Such was the usage at Denbigh in North Wales, ${ }^{6}$ York with

1 R. H., ii, pp. 356 et seq. (Cambridgeshire Inquest).

2 The Hundred Rolls are very full for both Cambridge and the shire, and contain many items concerning the messuages in the borough, the following quotation being characteristic and illustrative of our subject: " juratores illius burgi dicunt quod $B$. B. tenuit quoddam tenementum in villa de Cantabrigia, et solebat reddere praedicto tenemento ballivis . . . xiiij ${ }^{\text {or }}$ sol. et viij d. nomine hagabule" (R. H., i, p. 55). This record, much abbreviated, shows the use of hawgable and also a possible ambiguity in respect to this one case, for $14 \mathrm{~s}$. $8 \mathrm{~d}$. is very high where the average rent was Id. a tenement. The chief lord was the borough, the holder a religiosus who had paid no rent for ten years; possibly hawgable and rent were confused, though not probably, for the two are carefully separated as a rule (see $R$. $H$., ii, p. 327$)$.

${ }^{3}$ R. H., ii, p. 358 : "tres acras terrae ... ad hagabulum." This entry (R. $H$., ii, p. $35^{8}$ ) seems to be the only one to fall into error. The usual record discriminates: "Scolares de Merton tenent unum messuagium cum quadraginta et quinque acris terrae et quinquaginta sol. annui redditus in villa et in campo Cantabrigiae ... ad hagabulum et langabulum iiij s. et x d." (R. H., ii, p. 360 . For other records of the same sort see ibid., pp. 360, 36r, 370).

4 Cooper, Cambridge, i, p. 228 , a. $1483 ; £_{7}$ rs. $3 \frac{1}{4} \mathrm{~d}$. to use Cooper's figures, about the same as in the Domesday era when it was $£_{7} 2$ orae 2 d. (ibid., i, p. r8; D. B., i, f. I8ga). For this subject see Maitland, Township and Borough, p. 70. Domesday calls nearly every burgage rent, at Cambridge and elsewhere, gabulum or langabulum.

5 In the list of high gable rents in ${ }^{4} 8_{3}$ (Cooper, Cambridge, i, p. I8), the amounts run from $\frac{1}{2} \mathrm{~d}$. to $\mathrm{r}_{5} \mathrm{~s}$. for single tenements, but the last had 'lands' connected with it.

6 Williams, Denbigh, p. 306: "each of the burgesses ... shall render ... yearly $\mathrm{rd}$. . . on account of housegable for each of the burgages." From charter of $1283-90$. 
Bootham and other suburbs, ${ }^{1}$ and Bury Saint Edmunds, ${ }^{2}$ where, however, the payment was remitted to him and his heirs who bestowed a tenement in frank almoin. ${ }^{3}$ Hawgable was in use also in Ipswich, ${ }^{4}$ Maldon in Essex, ${ }^{5}$ Bedford, ${ }^{6}$ and Hertford. ${ }^{7}$ It is noteworthy that hawgable is confined to the older boroughs of the Danelaw. ${ }^{8}$ Denbigh in North Wales is an apparent exception. Denbigh was, however, a created borough, and its founder was a de Lacy, whose name is Danish and whose fellow Lincolnshire men probably took the name with them to the Welsh marches from their east English home.

Landgable, the commonest name for the burgage rent, was used in almost all the rest of the older English boroughs, and in these it was not applied to land in the common fields, as it was at Cambridge, whether such lands were or were not connected with particular tenements. Domesday constantly uses landgable,

1 Widdrington, Analecta Eboracensia, p. 121 : tenements were 'held of the king by housegable,' a. 1286-9o. A charter of Henry 11, granting lands to St. Peter's, uses the same name: "et eisdem terris . . . do . . consuetudines . . . excepto meo huusgavel, tanto videlicet quantum eaedem mansurae dederunt" (C.C.R., ii, p. 439). And again: "concedo . . terram in Usgata (Ousegate) . . quietam ab huusgavel " (ibid., p. 439). Terram seems to refer to land only, but it very probably means both the lands and houses in Ousegate.

2 Dugdale, Monasticon, iii, p. 124: tenements were held " per annuum redditum vocatum Had-govelle."

3 Arnold, Memorials of St. Edmund's Abbey, i, p. 303: " quando aliquis delegabat terram burgagii in elemosinam conventui . . . terra illa solebat de cetero esse quieta de haggovele." The monks could well afford to excuse a payment of a farthing or a penny. See also C. A. D., ii, pp. 224-225.

"C. A. D., ii, p. 176: a grant saves "the King's service of 1 d. ad hadgabulum." In another grant (ibid., p. 180), " the king's service, viz. haggabulum " is saved out of the chief lord's rent.

s C. P. R., a. 1403, p. 308: "rent of assize called 'hadgav'el.' "

- Records of the Corporation of Bedford, pp. IoI-112. The name there is 'hagable.' 'The hawgables of the Records are owed to the corporation, run from $3 \mathrm{~d}$. to 3 s. 4 d., and land, site of hospital, etc., all owe these rents, and probably continucd to owe them, though they were even then ten years in arrears. See also C. A. D., i, p. 9 .

' Robert Clutterbuck, The History and Antiquities of the County of Hertford ( 18 I 5-27), ii, app., p. I: "est ibidem quidam redditus assisi qui vocatur Haganel" (temp. Ilenry IV).

8 At Bormin in Cornwall, and possibly in other boroughs, there was an approximation to hawgables. A few ' ancient tenements' were still paying 'High Rents' (haw rents) in 1835 (Parliamentary Papers, 1835 , xxiii, p. 447). 
or infrequently gable, as a name for the fixed rents in the boroughs. In $1103^{-I} 5^{1}$ there was compiled what may be called an expansion of Domesday for a single city, Winchester, the old West Saxon capital. This, the Liber Winton', follows much the same plan as Domesday in giving the conditions of rent, customs, and holdership both 'T. R. E. et modo.' The landgable is a constant feature, though not every tenement is charged with it, and is of varying amount, from five to thirty pence, many rents being each six pence. ${ }^{2}$ The customals of the older boroughs seldom make any reference to the burgage rent; it is of small avail to look for landgable in them. Grants of real property, however, use the expression frequently, as at Gloucester, ${ }^{3}$ where the bailiffs rendered accounts de longabulo, ${ }^{4}$ Bristol, where John's charter recognized it, ${ }^{5}$ and Bath. ${ }^{6}$ Waterford knew the landgable, ${ }^{7}$ so too did Cork, ${ }^{8}$ the term being no doubt borrowed from Dublin, where it is found in John's charter ${ }^{9}$ and in the records

1 J. H. Round in The Victoria History of the Counties of England: Hampshire and the Isle of Wight, i, p. 527 .

2 See D. B., iv, pp. 532 et seq., ff. I to I rb. The usual entry runs: "A. tenuit $\mathrm{i}$ domum T.R.E., reddentem vi d. de langabulo, modo tenet B." who pays the same customs and so on (f. 3 ). Domus is the common name for messuage, sometimes terra. At times the landgable is mentioned though not its amount; at times the landgable may be contained in the consuetudines, as "modo tenet G. . . . et reddit langabulum et alias consuetudines" (f. 3); the holder T.R.E., rendered customs alone. One burgess "faciet consuetudines excepto langabulo" (f. 7). Another "tenuit i terram . . . et dabat langabulum" (f. $8 \mathrm{~b}$ ); the reference may be to land with no house thereon. The bishop of Winchester has the landgable frorn " $\mathrm{xxx}$ domus supra fossatum" (f. g). These rents are somewhat high when compared with those at Cambridge and other older boroughs.

${ }^{3}$ Stevenson, Records of Gloucester, p. 82 : " $1 \frac{1}{2} \mathrm{~d}$. for "longable' "; the term occurs in another grant of the same period (ibid., p. 83), in two grants cir. a. 1220 (ibid., pp. I03-104), in four grants cir. I 230 (ibid., pp. I4O, I4I, I 56, I57); the landgables run from 3 far. to $3 \mathrm{~d}$.

4 H. M. C., Rep., I 2, app., pt. 9, p. 420 (t. Ed. I).

5 Nichols and Taylor, Bristol, i, p. 96, cir. a. I188: "by landgable service."

6 King and Watts, Records of Bath, pp. 9, n. 5, xvi (a. 1218, 1250). It occurs in two grants; the amounts are $5 \mathrm{~d}$. and $6 \mathrm{~d}$. respectively. Cf. Winchester.

7 C. C.R., i, p. 158, a. 1232; H. M. C., Rep., 10, app., pt. 5, p. 316: " shall . . . pay his ... longable to the balif" (customal). Ibid., p. 329; "the Kings chief rent, called Longable."

8 C. C. R., i, p. $267, a$. 242.

9 Walsh, Dublin, i, p. 379; Gale, Corporate System of Ireland, app., pp. i-ivi; all land within and without the walls is held "in free burgage, and by the service of landgable." 
of transfer of communal realty. ${ }^{1}$ At Dublin, and possibly at other cities, there seems to have been confusion between the rents and the landgables due from messuages of which the city was chief lord, leading to complaints by the citizens of being overcharged, followed in turn by efforts on the part of the corporation to limit the size of both a messuage and its landgable. ${ }^{2}$

At Oxford the landgable seems sometimes to have been very high for a borough of its character, at least in the thirteenth century. On the other hand very few tenements were liable to this rent, unless the Hundred Rolls have omitted much. ${ }^{3}$ At Norwich the landgable was low even for an East Anglian borough. ${ }^{4}$ At Gloucester its incidence and amounts were the subject of a careful compilation. ${ }^{5}$ At Chester landgable was one

I Gilbert, Records of Dublin, i, p. 93, a. 126r; " land . . . escheated to the city for nonpayment of landgable for thirty years and upwards." See also ibid., p. 95 .

2 'These records are, however, too late in clate to be of much comparative value. The corporation tried to prevent confusion by ordering that the collector of the landgable should not collect the rents (Gilbert, Records of Dublin, i, p. 452, a. 1555). In I 546-47 a tenant complained that his tenement had to pay " moche more rent unto the landgable" than it should "by the old record or roll " (ibid., p. 4r6). The ancient landgable in Dublin was low and variable in amount $(C . P . R$., a. 1279, P. 379: $3 \frac{1}{2} \mathrm{~d}$; and the references below). According to the laws and usages of the city, in other words its customal, "the extent of each burgage within the city should not exceed 64 feet [frontage]; yearly landgable, I5d." (Gilbert, Records of Dublin, i, p. 224); one house had been charged with 5 s. to the landgable in 1500 (ibid., p. 386 ), which however was 'relysht' (released) to 12 d. a year for 59 years. Possibly the landgable had risen as the messuage increased in size; probably the landgable, the rent, and the record are all confused, for the essence of landgable is fixedness and perpetuity. It may be that causes which possibly had originally produced unequal landgables were still working in Dublin after the close of the middle ages.

${ }^{3}$ K. II., ii, p. 797: "N. de K. tenet quandam domum . . . et debet xxj à. de langabulo ... a ad firmam ville Oxon'." Another messuage owes $3 \frac{1}{2} d$. (ibid., p. 802), two others I 2d. (p. 797), another half a mark (ibid., p. 802), two others 24 d. each (ibid., p. 799).

- Stanley v. Mayor, etc., ff. I6, 20-2 I, 25 (28 Ed. I, I305, I333). There are landgables of a farthing, a half-penny, a penny. The last seems to include the rent of a strip in the ficlds, this is probably not the case, however, the appearance arising from the form of the recorl.

"Cole, Kental of the Houses in Gloucester, 1.455. The landgable was low and variable, ruming from one firthing for a "toft with adjoining curtilage" to $4 \mathrm{~s}$. 63 .1. for a "tenement with appurtenances." See the Rental, pp. 45 and 57 . The landgables were usually due the king, sometimes the Abbot of Ciloucester. See Stevenson, Records of the Corporation of Glowcester, Pp. $5_{5}^{6-157, ~ c i r . ~ a . ~} 1230$. 
name for the rent of assize; ${ }^{1}$ the same term may possibly have been in use at Lincoln. ${ }^{2}$ In the list of burgage rents which follows the references show where the little light here thrown on the subject has been obtained, - from a few published records of corporations, a stray item in the Patent Rolls, a casual reference in a grant or deed. In a later chapter (see p. 165) an attempt to explain the significance of the facts here set forth will be made; for the moment merely the rents themselves will be presented.

Borough Amount of Burgage Rent

Agardsley ......... $\mathrm{x} 8 \mathrm{~d} .^{3}$

Alnwick .........6 6d. -2 s. 6d. ${ }^{4}$

Altringham ....... r $2 \mathrm{~d}^{5}$

Barnstaple ...... 8d. (average) ${ }^{6}$

Bath ..........6. 6d. ${ }^{7}$

Bedford $\ldots \ldots \ldots \ldots 2 \frac{1}{2} \mathrm{~d}$.-rs. $7 \mathrm{~d} .{ }^{8}$
Borough Amount of Burgage Rent

Berwick ........6. 6d. ${ }^{9}$

Bideford ......... 6d., x 2 d. ${ }^{10}$

Bradford ......... I6d. (average) ${ }^{11}$

Bradninch ......6. 6d. ${ }^{12}$

Bridgnorth . . . . . . $\frac{1}{2} \mathrm{~d}_{.^{13}}$

Bridgwater ....... 6d., 12 d. ${ }^{14}$

${ }^{1} C$. A. D., iii, p. 394. A tenement in the "great street of Chester" owed " to the lord earl [of Chester] $\frac{1}{2} \mathrm{~d}$. . . . as Londgable." Gable is used also.

2 Ross, Civitas Lincolnia, p. $\mathrm{x}$. According to this author the burgage rent at Lincoln was Id. on each messuage, and was called the 'Landtoll Penny.' The statement as to the amount of the rent is correct (see C. $I . M ., \mathrm{v}$ (Ed. II), pp. r 98 and 363) though apparently only a happy guess by the author, no authority being cited. It is, however, almost the only correct historical statement in his book. If the name for the burgage rent be as Mr. Ross tells us, then Lincoln, where of all places one would expect to meet hawgable, must be placed in a class by itself in respect to a name for the rent of assize. Ross begins well by telling his readers that he has not found Lincoln's Charter from Henry II among the ancient records of the Corporation. The charter is, however, printed in Rymer, Foedera, i, p. 40 (quoted by Stubbs, Select Charters, p. I66) and H. M. C., Rep., I4, app., pt. 8, p. I. He also says (p. 6) that fifty years after the Conquest the murder fine brought in so little revenue that an annual tax (on boroughs) was imposed in its place. It almost seems as if Mr. Ross's work were not quite trustworthy.

3 Mosley, Tutbury, app. viii, p. 384.

4 Tate, Alnwick, i, p. 25 r.

5 Parliamentary Papers, 1835 , xxvi, p. 2574. The shilling rent covers a burgage and an acre for the same in the common fields.

6 H. M. C., Rep., 9, p. 2 rx, 2 Ed. I.

7 King and Watts, Municipal Records of Bath, pp. xvi, xvii.

8 Records of the Corporation of Bedford, pp. 5, IOI-I I2.

9 Scott, Berwick, p. 254.

10 Watkins, Bideford, p. I3.

11 James, History of Bradford, p. 6r.

12 Ballard, British Borough Charters, p. 46.

${ }^{13}$ C. I. M., v, p. 46, 2 Ed. II.

14 H. M. C., Rep., 3, p. 3 rx. 
Borough Amount of Burgage Renl

Bridport ......... 3d., etc. ${ }^{1}$

Bristol .......... Id. -2 s. 6 d. ${ }^{2}$

Burton-on-Trent .... I 2 d. ${ }^{3}$

Bury Saint Edmunds . $\frac{1}{2} \mathrm{~d}$.

Cacrmarthen $\ldots \ldots$ r. 12 d. $^{6}$

Cambridge ....... $\frac{1}{2} \mathrm{~d}$., Id., etc. ${ }^{6}$

Cardiff ......... 12d. ${ }^{7}$

Carlisle ........ $\mathrm{Id}^{8}$

Carlow.......... r 2d. ${ }^{9}$

Carnarvon ........ $12 \mathrm{~d}^{10}$

Chard ........ r 2 d. ${ }^{11}$

Chester . . . . . . $\frac{1}{2} \mathrm{~d}$., etc. ${ }^{12}$

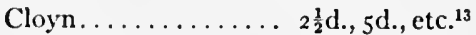

Colchester ........ rd., 2d., etc."

Congleton
Borough

A mount of Burgage Rent

Cork .......... I $2 \mathrm{~d} .{ }^{16}$

Dartmouth ...... 3d., 6d., etc. ${ }^{17}$

Denbigh ........ Id. ${ }^{18}$

Doncaster ....... 2d., 6d., etc. ${ }^{19}$

Drogheda ......... I 2 d. ${ }^{20}$

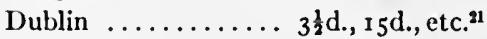

Dunheved ........ Id. ${ }^{22}$

Durham ......... I $\mathrm{I}_{4}^{\mathbf{l}} \mathrm{d}$, to $2 \mathrm{~s} .{ }^{23}$

East Grinstead..... 3 d. ${ }^{24}$

Evesham ....... 2d.-4od. ${ }^{25}$

Frodsham ........ I 2 d. $^{26}$

Gannoc ......... 24d. ${ }^{27}$

Gloucester........ 1 d. to $4 \mathrm{~s} .6 \mathrm{~d} .^{23}$

Grimsby .........6. $6 \mathrm{~d}^{29}$

${ }^{16}$ Hereford ......... 1 2d., $7 \frac{1}{2} \mathrm{~d} .^{30}$

1 C. I. M., i, p. 222, 5o Henry III; ibid., v, p. 67, 2 Ed. II.

2 Bickley, Litlle Red Book of Bristol, i, pp. 2-9.

3 Ballard, British Borough Charters, p. 49.

- Dugdale, Monasticon, iii, p. 153.

5 Daniel-Tyssen, Charters of Carmarthen, p. 49.

${ }^{6}$ R. II., ii, pp. 360, 361, 370 el pass.; H. M. C., Rep., I, pp. 70, 80.

7 Matthews, Cardiff Records, i, p. I 2.

${ }^{8}$ C. I. M., Henry VII, i, p. 7 I.

Hore, Wexford, v, p. 119 .

10 Lewis, Snowdonia, p. 68.

$"$ C. P. R., a. 1 286, p. $216 . \quad 12$ C. A. D., iii, p. 394.

${ }^{13}$ Caulfield, Council Book of Youghal, pp. 579-583.

14 Benham, Red Parchment Book of Colchester, pp. 45 et seq.; C. P. R., a. 1292, p. 18 .

15 Ilead, Congleton, p. 34 .

16 Caulfield, Council Book of Cork, p. x: "by such ... rent as the burgesses of Bristol render yearly of their burgages."

17 H. M. C., Rep., 5, pp. 598-600.

18 Williams, Denbigh, p. 306.

19 Tomlinson, Doncaster, pp. 35-36.

20 Ballard, British Borough Charters, p. 48.

${ }^{21}$ C. P. R., a. 1279, p. 379; Gilbert, Records of Dublin, i, pp. $224,386$.

${ }_{22}$ Peter, Launeston and Dunhered, p. 174.

${ }_{23}$ Hutchinson, Durham, ii, p. I2, note.

21 Itills, East Grinstead, pp. 40-4r.

${ }_{25}$ Dominicus, Chronicon Abbatiae de Euesham, p. $2 \mathrm{I} 1$.

26 Ballard, British Borongh Chorters, p. 50.

27 C. C.R., i. p. 378, a. 1252.

${ }^{28}$ Cole, Rental of the IJouses in Gloucester, 1.455, pp. 45-57.

29 C. I. . ., ii, p. 114, 4 Ed. I.

3) C. I. H., ᄂ, p. 213.6 Ed. II; D. B., i, f. 179a. 


\section{Borough Amount of Burgage Rent}

Huntingdon ........ av. under 5 d. ${ }^{1}$

Inistiogue ....... I $2 \mathrm{~d} .^{2}$

Ipswich ......... Id. ${ }^{3}$

Leeds $\ldots \ldots \ldots \ldots$ I6d. ${ }^{4}$

Leek ......... I $2 \mathrm{~d} .^{5}$

Leicester . . . . . . $\frac{1}{2}$ d., etc. ${ }^{6}$

Lewes $\ldots \ldots \ldots \ldots$ av. under $6 \mathrm{~d} .^{7}$

Lichfield . . . . . . I 2 d. ${ }^{8}$

Limerick ......... I $2 \mathrm{~d} .^{9}$

Lincoln ........... Id. ${ }^{10}$

Liverpool ......... I 2 d. ${ }^{11}$

Llandovery ........ I 2 d. ${ }^{12}$

London .......... Id., etc. ${ }^{13}$

Lostwithiel ......6. 6 d. $^{14}$

Ludlow .......... Id., 2d., etc. ${ }^{15}$
Borough Amount of Burgage Rent

Manchester......... I 2 d. ${ }^{16}$

Melcombe Regis .... Id., etc. ${ }^{17}$

Montacute ........ I6d. ${ }^{18}$

Morpeth ......... I6d.19

Newcastle ........ I $\frac{1}{2}$ d., 2d.. etc. ${ }^{20}$

Newport . . . . . . . 6d. and I $2 d^{21}$

New Ross ........ 1 $2 \mathrm{~d}$., ? $3 \mathrm{~d} .^{22}$

Northampton ...... Id. ${ }^{23}$

Norwich ....... $\frac{1}{4} \mathrm{~d}$., $\frac{1}{2} \mathrm{~d}$., Id. ${ }^{24}$

Okehampton ....... I 2 d..$^{25}$

Oswestry ........ I 2 d. $^{26}$

Oxford $\ldots \ldots \ldots \ldots 3^{\frac{1}{2} \mathrm{~d} . \text {, etc. }^{27}}$

Pevensey $\ldots \ldots \ldots \ldots$ 5d. to $20{ }^{28}$

Pontefract....... I $2 \mathrm{~d} .{ }^{29}$

Portsmouth ....... $\frac{1}{4}$ d., Id., 2d., etc. ${ }^{30}$

1 D. B., i, f. 203 a.

2 Gale, Corporate System, app., p. xii.

${ }^{3}$ C. A. D., ii, p. ${ }_{7} 6$.

4 Wardell, Municipal History of Leeds, app., p. iv.

5 Ballard, British Borough Charters, p. 50.

6 Bateson, Records of Leicester, i, p. 382.

7 D. B., i, f. 26 a.

8 Harwood, Lichfield, p. 38r.

9 Lenihan, Limerick, p. 48, note I.

${ }_{10}$ C. $I$. M., v, pp. I98, 363 ; Ross, Civitas Lincolnia, p. I.

11 Picton, Liverpool Records, i, p. I3.

12 Parliamentary Papers, 1835 , xxiii, p. 301.

${ }_{13} C$. I. M., Henry VII, i, p. 206, and others.

14 Ballard, British Borough Charters, p. 48.

15 Ludlow Charters, pp. 60-61.

${ }_{16}$ Whitaker, Manchester, ii, p. 58r.

17 Moule, Weymouth, p. Io6.

18 Somerset Record Society, [Publications], viii, pp. 2 Iof.

19 H. M. C., Rep., 6, p. 527.

20 Brand, Newcastle, i, pp. 75, 347.

${ }^{21}$ C. I. M., v (Ed. II), p. 94; Parliamentary Papers, 1835, xxiv, p. 773.

${ }^{22}$ Hore, Wexford, i, p. I5I.

${ }^{23}$ C. $P . R$., a. I3I4, p. I99.

24 Stanley v. Mayor, etc., ff. I5, I6, 25.

25 Ballard, British Borough Charters, p. 48.

${ }_{26}$ Tait, Mediaeval Manchester, p. 65.

${ }_{27}$ R. H., ii, p. 802 et pass.

${ }_{28}$ D. B., i, f. 2 ob.

${ }^{29}$ H. M. C., Rep., 8, p. 269; Parliamentary Papers, I835, xxv, p. I673.

30 East, Records of Portsmouth, pp. 493-502. 


\begin{tabular}{|c|c|}
\hline Borough & A mount of Burgage Rent \\
\hline Rathcool & $\ldots \ldots 12 \mathrm{~d} .^{1}$ \\
\hline Rathmore. & $\ldots \ldots 12 \mathrm{~d} .^{2}$ \\
\hline Ruyton ... & $\ldots \ldots \ldots 12 \mathrm{~d} .^{3}$ \\
\hline Rye .... & . 3d.-2s. 6d. \\
\hline Salisbury . & . 12d. ${ }^{6}$ \\
\hline Salford.... & . I $2 \mathrm{~d} .^{6}$ \\
\hline Scarborough & $\ldots 4$ d. and $6 d^{7}$ \\
\hline Shaftesbury & $\ldots \ldots \ldots \frac{1}{4} \mathrm{~d}^{8}$ \\
\hline Shrewsbury & $\ldots \ldots$ av. under $7 \mathrm{~d} .{ }^{9}$ \\
\hline Stockport & $\ldots \ldots \ldots$ I2d. ${ }^{10}$ \\
\hline Swansea . . & $\ldots \ldots$ I $2 \mathrm{~d}^{.11}$ \\
\hline Swords ... & $\ldots \ldots{\text { 1 } 2 d^{12}}^{12}$ \\
\hline Taunton. & $\ldots \ldots$ av. $6 \mathrm{~d} .{ }^{13}$ \\
\hline Tewkesbur & $\ldots \ldots$ I2d.14 $^{14}$ \\
\hline
\end{tabular}
Borough Amount of Burgage Rent
Uttoxeter ........ 12d. ${ }^{15}$
Wallingford $\ldots \ldots \ldots$ ? rd. $^{16}$
Walsall $\ldots \ldots \ldots \ldots$ ind ${ }^{17}$
Waterford ...... r 2 d. (probably) ${ }^{18}$
Wells .......... I 2 d. $^{19}$
Wexford $\ldots \ldots \ldots$ I 2 d..$^{20}$
Weymouth ....... Id. -5 s. $^{21}$
Whitby ......... $5 \mathrm{~d}^{22}$
Winchelsea ........ Id., 2d., etc. ${ }^{23}$
Winchester ......... rd., $6 \mathrm{~d} .{ }^{24}$
Woodstock ......... av. 4 d..$^{25}$
Yarmouth ....... Id.(probably) ${ }^{26}$
York $\ldots \ldots \ldots \ldots$ Id. $^{27}$
Youghal $\ldots \ldots \ldots \ldots$ I $_{2 \mathrm{~d}}{ }^{28}$

There seem to be many shilling boroughs in this list, but as far as size and trade go they might all be added to London without very much increasing its population or its commerce. They are new boroughs and their charters commonly state the amount

1 Gale, Corporate System, app., p. x.

2 Ibid., app., p. xx.

3 Parliamentary Papers, 1835 , xxvi, p. 2858.

4 Holloway, Rye, Pp. 323-326.

${ }^{5}$ R. C. Hoare, The II istory of Modern Wiltshire, vi, p. 738.

6 'Tait, Mediaci'al Manchester, P. 63.

7 Baker, Scarborough, D. 28 ; C. C. R., i, p. 417.

8 Mayo, Records of Shaftesbury, p. 79.

I). B., i, f. 252 a.

10 Tait, Mediaezal Manchester, p. 63.

it I3allard, British Borough Charters, p. 47.

12 Ibid., P. 49. 13 D. B., i, f. 87b.

14 Bennett, Terikesbury, P. $32 \mathrm{~s}$.

15 Mosley, Tuthury, app. ix, p. 385 .

${ }^{16}$ IHeclges, 11 "alling ford, i, P. 345 .

17 Willmore, Wialsall, p. Ito.

18 II. М. C.. Rep.. 10, alp)., [t. 5, p. 3 I6.

19 Ballard, British Borough Churters, P. 49.

20 (iale, Corporate System, appo, p. xvii.

21 Moule, H', 'mouth, p. 106.

22 . Itkinson, Ithitly', p. 268.

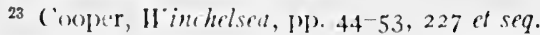

24 (.. I. .I., Ilenry VII, i, p. 255, 6 IIenry VII; D. B., iv, pp. 531 et seq.

${ }_{23}$ Ballard, Woodstock, pp. 8, 9 .

26. I). B., ii, P. I18a. 27 C. P. R., a. 1296, p. 208.

28 Caulfudd, Foughal, p. $1 x$. 
of the burgage rent. At Bridgwater the twelvepenny rent is taken from a grant, which may be inclusive of a reserved rent, a rent charge. The place is supposed to have been and probably was a shilling borough. The halfpenny messuage at Bridgnorth was on castle land; its rent was not fixed by the rents of the borough. At Hereford in the Domesday era the rents were less than those of the fourteenth century. At Berwick the burgage rent was called burgh mail; but Berwick had been part of Scotland. At Durham the term for the rents of assize was landmale, at Ludlow the soc rents.

At Scarborough the fourpenny rent was for tenements whose houses stood with their ends to the street; when the side of a house faced the street the rent was sixpence; possibly such tenements were larger. ${ }^{1}$ Scarborough had another custom in respect to its burgage rents, which, as far as is yet known, was unique as well as peculiar: he who became chief lord or direct holder of eight or more messuages and enclosed them in one paid but one rent of sixpence for all. ${ }^{2}$ Sixpence was the average landgable at Winchester when Liber Winton' was compiled; the penny burgage rent is of a later date. Both rents and burgage rents were higher there in $1_{103-15}$ than in any other important borough in England. ${ }^{3}$

At some of the small chartered boroughs the twelvepenny rent lay on the burgage alone: land in the common fields was subject to an additional rent of a shilling for each acre, as at Llandovery; a shilling for three acres, as at Oswestry; or fourpence an acre for each of three acres, as at Ruyton. At Denbigh, while the ordinary burgage rent was a penny, one burgess paid fourpence for his tenement, two other burgesses each twelvepence

1 The gable lay on the land rather than the house (Brown, Yorkshire Inquisitions, i, p. I64).

2 Ibid., i, p. 22. This custom was declared in 1250 during the course of a suit between the king and the abbot of Citeaux, certain of whose tenements the king had claimed. There were eight all told (they must have been contiguous) for which the abbot rendered only $6 \mathrm{~d}$. as gable. The jurors said that "the custom of the borough is such, that if any burgess enclose in one eight messuages or more yielding gablage severally, he shall yield one gablage only, that is $6 \mathrm{~d} . "$

3 To follow the rule they should remain so; rents in the Domesday era are the same in amount as rents in the era of the Renaissance. 
for theirs, and a third was charged with one and fourpence for his two messuages, possibly because he was a parson. Denbigh and Gannoc are the same. As founded in $125^{2}$ the town was known as Gannoc; ${ }^{1}$ then the Welsh wasted it so thoroughly that Denbigh was a new borough. At Portsmouth pepper rents were payable from a few tenements; they seem to be the only rents in kind due the bailiffs toward the Firma Burgi from messuages in any borough. ${ }^{2}$ It need hardly be said that the bailiffs did not pay pepper to the Exchequer. The existence and retention of the pepper rents were probably due to the fact that parts of Portsmouth, as the parish of Portsea, had been held originally by monasteries, as Southwick, and pepper remained as part of the burgage rent.

By no means all the boroughs of mediaeval England, or even all those of this essay, appear in the preceding list, which might have been longer were it not that many of the borough histories, so-called, devote so much space to Roman fiction that they have none left for English fact. It would seem, however, that a sufficient number of the boroughs, especially of the larger boroughs, has been enumerated to be geographically representative, and to show, both in time and place, the variability of the burgage rent. ${ }^{3}$

It may be premised that in boroughs which had a grant of the Firma Burgi the elected town bailiffs collected the chief rents. In the larger boroughs which had no grant of the farm the rule was the same, though they acted often for the sheriff; in small boroughs the collector was usually the lord's steward or bailiff. ${ }^{4}$

1 The rent was two shillings for two acres without, and half an acre within, the walls.

2 All sorts of rents in kind, as hens, cloves, etc., are payable from tenements in some boroughs, notably Leicester, but they are not burgage rents.

3 This rent was the only burden on the tenement except the cases previously mentioned where each burgage holder must find a man to defend the borough at 1)enbigh, and that of the burgage at Liverpool which had to provide stable for the lord's horses. To these must be added another, a messuage in Clester which was obliged to find a " judicator yearly in the portmote of Chester" (C.A.D., iii, p. 350, 24 Henry $(1)$.

4 C. C. R., i, p. 378. At Gannoc in 1252 the burgage rent must "be paid each year to the king's bailiff."

At Bury Saint Edmunds one tenement paid " $\frac{1}{2} \mathrm{~d}$. yearly to the provost of St. Edmund's for Hadgovel" (C.A.D., ii, p. 224), while another paid the same rent to 
At Kinsale, which had no grant of the farm as far as evidence shows, the town bailiffs were the collectors, ${ }^{1}$ and at Liverpool, whose Firma Burgi was intermittent, being granted for short terms at varying intervals, the bailiffs collected the burgage rents and paid them to the Earl of Lancaster, lord of the borough. ${ }^{2}$ Burgages are found lying within the fee of the castle; in Norwich at least the sheriff of the county collected their rents. ${ }^{3}$ Now and again a borough which could show no grant of the Firma Burgi resisted collection of rents by the lord or his official; thus did Barnstaple ${ }^{4}$ and Petersfield. ${ }^{5}$

Default in payment of the burgage rent for any considerable period entailed forfeiture of the tenement to the community, if the borough was 'held in chief.' ${ }^{6}$ In boroughs which had no grant of the Firma Burgi the lord might seize such a tenement as a matter of course, though in some their charters provided that tenantless tenements, that is those which paid no rents, should be taken by the community. ${ }^{7}$ It seems that in the older

the sacristan of the abbey (ibid., p. 225). The result was the same; no doubt St. Edmund got the rent.

At Weymouth the burgesses paid their rents to the abbot or his representative (Moule, Weymouth, p. 17).

At Pontefract, "quum pretor [? praepositus] pacaverit domino firmam burgi" (not a fee-farm) " . . . removebit illum dominus et ponet quemcumque voluerit" (H. M. C., Rep., 8, p. 270); but the burgesses shall be preferred, "si tantum dare voluerint quantum alii."

1 Caulfield, Council Book of Kinsale, p. Ixxxv. All the revenues of the town were accounted for before two elected burgesses. If the two were negligent the Earl of Desmond acted as auditor.

2 Picton, Liverpool Records, i, p. 7 .

3 Stanley $v$. Mayor, etc., f. 24.

4 H. M. C., Rep., 9, pt. I, p. 2 I 2 (Io Henry IV).

5 Atcheson, Case of the Borough of Petersfield, p. I5 (t. Henry VIII). This borough had been paying a fee-farm rent (at least that is what the burgesses thought it) of $£_{7}$ Is. 2 d. to its lord, the Duke of Buckingham, and had acted in all respects as a real corporation; then there came a change of lords, the Duke having been attainted, and conflict arose between lord and borough over the rents. The burgesses could produce no proof of their assertion that they held the town in fee, and lost their case.

${ }^{6}$ See H. M. C., Rep., Io, app., pt. 5, p. 316: "And that it be lawefull to the ballif ... to have an action of dette agaynste hym that is soo behynde [in payment of the longable]."

7 Mosley, Tutbury, p. 384: "if it shall happen that any burgage be empty and void beyond one year and a day, then the other burgesses shall answer for the rent 
boroughs such forfeiture was not strictly enforced, probably because the rent was so small. Sometimes collection of the gable appears to have been neglected for years and then often forgotten.'

It is probable that at an early date most of the messuages in a borough paid landgable or burgage rent. ${ }^{2}$ It is certain that in the Domesday era many tenements paid none, ${ }^{3}$ while in the period immediately preceding the Reform Bill the only tenements which paid chief rents were usually the fag-ends of boroughs. ${ }^{4}$ This result came mainly from division of the original messuages, ${ }^{5}$ for the records show very little extension of the borough bounds during the mediaeval period. ${ }^{6}$

of the same as of others, together with all service, secular exaction, and demand to free burgages belonging." Charter to Agardsley, $t$. Henry III. It is implied that the commonalty is now the chief lord of such a tenement. At Uttoxeter the charter left no ground for doubt: a burgage that was empty for a year fell to the burgesses, who took it, paid its rent to the lord (Earl of Derby) and made their profit of it; the lord renouncing further claim thereto (ibid., pp. 385-386, 36 Henry III).

At Liverpool, in the intervals between grants of the farm to the burgesses for short terms, the bailiffs accounted to the lord (Earl of Lancaster) for the rents of the burgages, empty or otherwise. The original number of messuages was 168 , and it remained at this figure till 1628 . If every tenement paid its rent the sum would be $£ 88 \mathrm{~s}$. In 1296 , it was $£ 8$ 7s. 6d. (Picton, Liverpool Records, i, pp. 7-8): in 1327 , all were occupied, for the rent was $£ S \&$ s. (ibid., p. 9). In 1346 it was $£ \delta 4$ s. $10 \frac{1}{4} \mathrm{~d} .+14 \frac{1}{1} \mathrm{~d} .+6 \mathrm{~d}$. (ibid., p. 13 ), though why $1_{4}^{1} \mathrm{~d}$. for $1_{10}^{3}$ burgages and $6 \mathrm{~d}$. for $\frac{1}{2}$ a burgage should be separated from the main amount is not apparent. These recoris show that the lord in such boroughs as Liverpool lost the rents of empty messuages. They all refer, of course, to original burgages on which lay the burgage rent.

1 See $R$. $I I$., i, p. 55, where action was taken by the burgesses of Cambriclge in a case where payment of hagabulum had not been made for ten years. This, when the tenement had a tenant, is not forfeiture but it is rather a seizure for debt; the name forfeiture is not suitable as it conveys a different meaning. Such a thing as a tenement without a lord, other than the borough lord, could hardly exist in any of the larger boroughs. There might, however, be empty messuages anywhere; in the small boroughs their chief lord was commonly the lord of the borough.

2 That every messuage must pay its landgable was certainly the case when a borough wats created by charter.

3 See D. B., i, f. 18qa el pass.

4 Echard Porritt, The L'nreformed Ilouse of Commons (1903), i, Pp. 33-41.

s See in respect to this subject Stubbs, Constitulional II istory of England (1880), iii, p. 453 .

6 Forgetfulness in the collection of the burgage rent, though it had the ultimate effect of causing the disappearance of original burgages, was of small moment till late in our period. 
Two courses were commonly open to a burgess when he divided his property; he might divide the burgage rent or continue to pay it himself. The latter course would leave the alienated part, now another messuage, free from any landgable. ${ }^{1}$ In most of the shilling boroughs there seems to have been no option; the burgage rent remained at twelvepence regardless of division, though in a few of these towns there is evidence that the first course was sometimes the one followed. ${ }^{2}$ These charter-created, twelvepenny, baronial boroughs, however, are not typical of English urban tenure; some of them are un-English in various ways, and they are of small importance in every respect as compared with the older boroughs on which no charter conferred the burgage tenure but whose charters found the tenure there; they are the boroughs of England whose tenure forms our subject. In them all sorts of processes seem to have been at work. Nothing prevented a burgess from dividing his landgable as he divided his messuage, and sometimes he did so. By the time, however, that divisibility reached an important stage in the boroughs, the burgage rent, low enough at the start, even as low as or lower than the minimum coin of the realm in some cases, had become so small a fraction of the worth of the tenement that it seems usually to have been allowed to remain on what was left of the original messuage. ${ }^{3}$

I It is, of course, possible that in the older boroughs there were tenements which had never paid landgable and which had no lords but their holders, free allods as it were. The practically universal prevalence of overlordship during the later Saxon period, intensified after the conquest, would make the number of such tenements negligible.

2 The charters to such boroughs forbade increase above I2d.; their records show no decrease below I 2d. There are exceptions, as at Salisbury (Hoare, History of Modern Wiltshire, vi, p. 738) where "predicti cives . . . dicunt . . . quod ... teneat unusquisque suum liberum tenementum ... reddendo ... episcopo [Sarisbiriensi] . . . pro plena placea duodecim denarios per annum, et qui plus vel minus tenuerit secundum eandem quantitatem respondeat pro omnibus serviciis." At Liverpool in I346 (Picton, Liverpool Records, i, p. I3) the bailiffs accounted for the rent of "one burgage, the 8th part, and I6th part of one burgage," $14 \frac{1}{4} \mathrm{~d}$. This shows that as the burgage was divided, so was the burgage rent, for $2 \frac{1}{4} \mathrm{~d}$. is the correct proportion for $\frac{3}{16}$ of a twelvepenny burgage. At each of these boroughs, therefore, the buyer of a fraction of an original burgage was responsible for a proportional share of the rent.

${ }^{3}$ Where there had been a change of holders the term original burgage would be 
Though there is great variability among the older boroughs, and though the rents of all are low, it seems that the landgable of the ancient boroughs of the south and west was in general slightly higher than that of those of the north and east. ${ }^{1}$ The gables at Winchester about $1103^{-15}$ were fairly constant and fairly high, and most of the tenements owed them. ${ }^{2}$ At Cambridge in 1086 the rents were lower on the whole, they varied more in amount, and proportionately fewer tenements owed them, though the amount of the landgable did not change throughout the middle ages. Gloucester resembled Winchester to some extent while Bristol and Dublin more nearly resembled Cambridge. ${ }^{3}$

only relative; one part would be as original as another. Possibly some messuages were never divided. Custom and tradition, however, usually settled on one part as the 'capital messuage.'

1 London is included in the latter class; the shilling boroughs are in neither. No attempt will be made here to separate the older boroughs into classes according to size of original landgable. For this see, however, p. 165. Secondary influences had affected the boroughs of north and east.

2 For Winchester see Liber Winton', ff. I et seq.; for Cambridge, D. B., i, f. I 89a and $R . H$. ii, pp. $35^{6} \mathrm{et}$ seq.

3 Though it may be taken as a matter of course that the landgable never increased with the increase of messuages, sometimes the fact is directly stated, as in the following extracts from a charter of Henry I giving lands to St. Peter's at York: "Et eisdem terris . . . do et confirmo easdem . . . consuetudines . . . excepto meo huusgavel, tanto videlicet quantum eedem mansure dederunt, ante quam fratres ejusdem hospitalis eas habuerunt, ne propter numerum domorum et hostiorum plus reddant" (C.C.R., ii, p. 439). Nor might it be decreased, for the custom at Scarborough which allowed him who enclosed eight or more messuages in one to pay the landgable of but one messuage for all seems to be wholly cxceptional.

In Bury Saint Edmunds only 'certa tenementa' were held by 'hadgovelle' (I) it is all for the other course, and the monkish annalist of $1175^{-1200}$ lanents that " terrac autcm illae, nunc tempore, in tot partes divisae sunt, quot vix scitur a quo ille census dari debet" (Arnold. Memorials of St. Edmund's Abbey, i, p. 303).

At Ciluucester the rent seems to have lain on the land rather than on house and land, for a certain tenement lies in decay" and "pays nothing by" year " though the holder must still pay his landgable (Cole, Renlul of the Ilouses in Glowester, p. 5). Fet at prior had "newly built two tenements . . . and he renders therefor for landgable" (ibid., p. 7). One tenement in Gloucester rendered $22 \frac{1}{2} \mathrm{~d}$. as landgable; it was divided and each holder thereafter rendered $11 \frac{1}{4}$ (l. (ibid., p. 55).

At Winchester probably the landgable was divided with the divided tenement and consequent crection of new houses: "B. fecit supra illam terram i. domum 
In all the older boroughs, to summarize the extent and situation of the burgage rent, there were tenements which paid no landgable, even at the date of the earliest records. In Winchester these were a minority, elsewhere as a rule a majority, which grew with the growth of the borough (the rule for the rent being its retention on some shrinking part supposed to represent the original tenement) until the rise in values and prices made the retention of the landgable, which was probably never more in some boroughs than a sign or symbol of lordship, a matter of its significance and not of its worth. Whatever the case in the beginning, eventually the greater number of the tenements paid no burgage rent whatever, and many original burgages simply faded away. Freedom from the landgable, however, made no difference either to the tenure by which the messuage was held or to the status of the holder; he was still a burgess and held his tenement in free burgage. ${ }^{1}$

In the older boroughs the 'lands' in the common fields seem to have borne no rent at all. Probably at one time most messuages, as the word was commonly used, would have their connected acre-strips; the burgesses were mostly farmers. Probably the amounts were not very unequal, and the messuage may have been considered as consisting in part of these lands, with the burgage rent covering a burgess's whole tenement. When

quae nec fuit T. R. E. Modo tenet eam O., . . . et reddit regi 5 d. de langabulo" (Liber Winton', f. 7b). Nearly all the entries in Liber Winton', however, use domus and not messuagium or tenementum; most domus pay landgable. As the sum of the landgable was not increased, division of the rent is probable.

In direct contrast to the custom at Winchester, at Oxford, according to the witness of the Hundred Rolls, only one tenement in thirty-five, or thereabout, was liable to landgable ( $R . H$. . ii, p. 797). Either the records omit much, or messuages had been joined and their burgage rents as well (the relatively high landgable supports this view), or the dead hand held many tenements and their landgables therewith, for such a condition, though infrequent, was possible. (See C. Gross, in American Historical Review, July, 1907, "Mortmain in Medieval Boroughs.")

1 The term burgess is confined to the freeholder till the later part of our period. Extension of the term to all in-burghers was often contemporary with loss of connoted political privileges, like extension of the franchise in the later Roman Empire. Tenants at will and termors were not burgesses in the early part of our period; "observe that such tenements only are free as owe neither service nor rent to any one" (Boys, Sandwich, p. 523). 
mobility had destroyed equality, the rent, relatively unimportant at almost any time and place, would be regarded as lying on the part whose ownership was apparent, the burgage. of later days within the ditch or wall. ${ }^{1}$

The part of the original messuage which was supposed to represent the whole, and on which the rent of assize rested, seems in many cases to have been called the capital messuage, chief tenement, or chief house, the first term being the oldest; the corresponding landgable was often called the 'chief rent.' At times capital or chief may have been used because of the size of the messuage; in the later part of the period because a tenement might have smaller tenements thereon depending. In the earlier part of our period, however, the name seems restricted to the first sense alone, as at Pontefract, ${ }^{2}$ Leeds, ${ }^{3}$ and Scarborough. ${ }^{4}$

The capital messuage seems to have been likely to decrease in size in a growing borough, ${ }^{5}$ the name still remaining with the remaining part. ${ }^{6}$ Rent-charges seem to have lain oftener on

1 Arnold, Memorials of St. Edmund's Abbey, i, p. 303. At one time Cambridge had rents both on houses with their lots and on lands, 'hawgable and landgable'; in the last compilation the land rents disappeared. Some of the chartered and created boroughs had a separate rent for each parcel of connected land.

${ }^{2}$ H. M. C., Rep., 8, p. 269. From Roger de Lacy's charter (embodying burghal custom) of 5 Rich. I. The same privileges were granted to those who held parts of toits as to those who held whole tofts, but "siquis habuerit plures domos in tof to suo et locaverit eas " the occupants must pay $4 \mathrm{~d}$. a year for leave to trade. However, "qui in capitali domo manserit quietus erit et liber sicut burgensis esset." Privileges of this sort were not restricted to any one messuage at Chesterfield (Yeatman, Records of Chesterfield, p. 40).

3 Warclell, Leeds, app., p. iv.

- Brown, Yorkshire Inquisitions, i, p. 22. This is the previously quoted case of the enclosure of the eight messuages by the abbot of Citeaux. The abbot had seven other messuages " where the capital messuage . . . is situate," and every messuage was an original holding, paying its landgable. When the seven ceased to pay landgable, the eighth which still paid it was the capital messuage. If a holder of any one of the eight messuages had enclosed seven others, his messuage would have become 'capital' as the others ceased to pay landgable.

"As at Wycombe where, $t$. Henry III, Adam Carter granted "a part of his capital messuitge" (II. MI. C., Rep., 5, p. 560).

6 As at leicester where in 1286 rent-hens were granted from "the chief messuage which once was W. of B.'s" (Bateson, Records of Leicester, i, p. 389); the name of the former holder elings to the place just as it does to many a homestead in modern days; the messuage is still capital. 
capital messuages, an economic condition which perhaps is only to be expected, for the buyer of part of an original tenement would naturally prefer to get it unencumbered. Also he might wish to raise money on his purchase and could do so more easily if there were no previous burden thereon. If the capital messuage gave sufficient security the rent-charge would thus be thrown back on it. ${ }^{1}$ During the later part of our period, and in London at an early date, the term capital messuage seems to have another meaning, the dwelling-house of one who holds and leases other houses; except in London, however, this is alternative to and not exclusive of the older meaning. ${ }^{2}$ The chief importance of the capital messuage lies in its greater tendency to inalienability in boroughs of restricted devise, its connection with dower, and, though beyond our period, in its connection with the parliamentary franchise. ${ }^{3}$

1 See Bateson, Records of Leicester, i, p. I83. The capital messuage may often have been more valuable than the average tenement and thus have afforded greater security for a loan. At Scarborough John Ouhtred's capital messuage was worth 40s. a year; the greatest value of any of his other burgages was $24 \mathrm{~s}$. and their average value about ${ }_{5} \mathrm{~s}$. (Brown, Yorkshire Inquisitions, iii, pp. 9r-93; the $5 \mathrm{~s}$. , etc., are rents, but not burgage rents).

At Norwich temp. Ed. I two tenements were conveyed by various holders to the Friars Minors (Minor Brothers). They were original tenements owing each a penny landgable. Two burgesses pledged themselves to pay this gable to the farm, and each placed a rent-charge of a penny on his capital messuage with that object (Stanley v. Mayor, etc., f. I5); in this case it seems that, when a tenement was grasped by the dead hand, it escaped every financial obligation. Sometimes the term may refer to size alone: "one capital messuage . . . in . . . Norwich ... and ... six ... small messuages" (ibid., f. 47).

There seems to have been a desire to keep a capital messuage as near the family as possible. See Frost, Hull, p. 46, note; Swinden, Yarmouth, p. 804 .

${ }^{2}$ See C. A. D., i, p. I93; ibid., i, p. I76, I9 Ed. IV, " a chief tenement with close and two tenements adjoining," both in London; H. M. C., Rep., II, app., pt. 3, p. I6I (Lynn, 6 Henry VI), a " chief tenement [which] has different tenements . . . under one roof, pertaining to ... the said chief tenement "; C. I. M., Henry VII, i, p. 208, "a capital messuage ... . in the suburbs of Colchester, three renters thereto adjacent"; ibid., i, p. 304, $t$. Henry III (London), a 'chief house' with thirteen shops.

3 See Stubbs, Constitutional History of England (1880), iii, p. 453. 


\section{Rents and Sales of Messuages}

What was the actual worth of the messuages whose landgables, when they paid any, seldom exceeded a penny or twopence, in the older boroughs at least? Unsatisfactorily for us, though probably not for him, the burgher of the twelfth, the thirteenth, and sometimes later centuries seems seldom to have transferred a tenement without retaining a perpetual rent in addition to a sum paid down. The feudal idea of holdership may have influenced him, or he may have wished to retain the right to escheat, a possibility of some value in boroughs where freedom of alienation was restricted. Where the rent retained is only nominal, as a rose, a clove, or an arrow, the sum paid down may be taken as the price of the tenement, but in such cases the records often forget to state what sum was paid, or whether anything were paid at all. Records of sale simple show prices varying from $4 \frac{1}{2}$ marks for a shop in Bath to £go for a messuage in London. The appended illustrations of simple sale, though few, show how disproportionate a ratio existed between the value of a tenement and its landgable, especially when it is considered that probably in every case the messuage in question was only a fraction of the original tenement. ${ }^{1}$

1 The facts connected with one of the Norwich messuages show how quickly realty could be transferred in the boroughs. On July 29 , J. granted it to $\mathrm{Y}$. for $£_{40}$; on August $4, \mathrm{Y}$. granted it to $\mathrm{A}$.; on August $9, \mathrm{~A}$. granted it to $\mathrm{J}$., the original holder, for $\mathfrak{f}_{42}$. The grant of a tenement for 3 s. at London is quoted to show how little value a tenement might have; that at Dartmouth, made by a chaplain's daughter, is too small to be representative. The terms of the last London grant were peculiar: "2.45. a year for six years and 10 marks a year for the following twent $y$-four years."

Records of grants where the grantor retained a rent exist in large numbers. Thus in 1228 the king granted an escheated tenement in London to William Marshal, Earl of Pembroke, and the earl sold the house almost at once for I 10 marks, retaining a rent of 2s, or one hat (capellum) of peacock's feathers; the chicf lord's service of Sd. was saved as well (C. C. R., i, pp. 74,79$)$. 


\section{Borough Sale Price}

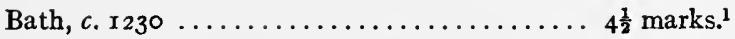

Bridport, $t$. Edward I ................ 14 marks. ${ }^{2}$

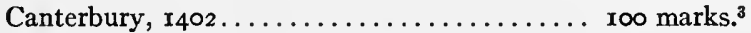

Dartmouth, $t$. Edward I.............. I5s., ro marks. ${ }^{4}$

Hythe, $t$. Edward III ................. ro marks. ${ }^{5}$

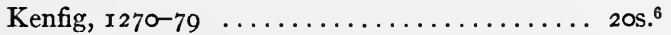

Leicester, I $298-99 \quad \ldots \ldots \ldots \ldots \ldots \ldots \ldots \ldots £_{20}{ }^{7}$

London, Ir $89-96 \ldots \ldots \ldots \ldots \ldots \ldots \ldots \ldots £_{90 .}{ }^{8}$

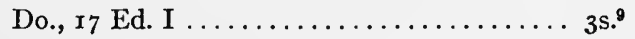

Do., I9 Rich. II $\ldots \ldots \ldots \ldots \ldots \ldots \ldots \ldots £_{7} 4 \mathrm{~s} .+240$ marks ${ }^{10}$

Norwich ........................ 40 marks. ${ }^{11}$

Do., $\mathrm{I} 287 \ldots \ldots \ldots \ldots \ldots \ldots \ldots \ldots \ldots \ldots £_{42 .}{ }^{12}$

Do., $1313 \ldots \ldots \ldots \ldots \ldots \ldots \ldots \ldots \ldots \ldots \ldots \ldots \ldots$ 13. $^{13}$

Reading, I9 Henry VI $\ldots \ldots \ldots \ldots \ldots \ldots \ldots £_{1} 6 . .^{14}$

Do., 20 Henry VI $\ldots \ldots \ldots \ldots \ldots \ldots \ldots £_{20.16}$

Ross, r $285-86 \ldots \ldots \ldots \ldots \ldots \ldots \ldots \ldots \ldots \ldots \ldots \ldots \ldots \ldots$ 53. $4 \mathrm{~d} \cdot{ }^{16}$

Rye, 30 Ed. I $\ldots \ldots \ldots \ldots \ldots \ldots \ldots \ldots \ldots$ marks. ${ }^{17}$

Do., 5 Henry V $\ldots \ldots \ldots \ldots \ldots \ldots \ldots \ldots £_{7}$ Ios. $^{18}$

Do., 5 Ed. II $\ldots \ldots \ldots \ldots \ldots \ldots \ldots \ldots \ldots$ marks. ${ }^{19}$

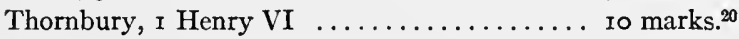

Westmelne, 5 Henry III............... I2 marks a year for life

1 King and Watts, Records of Bath, p. xvi. of grantor. ${ }^{21}$

2 H. M. C., Rep., 6, p. 48 ז.

${ }^{3}$ Ibid., 9, pt. I, p. 169 .

Ibid., 5, pp. 599, 6ог.

${ }^{5}$ Ibid., 6, p. 512.

${ }^{6}$ Clark, Cartae Glamorg., iii, p. 529.

7 Bateson, Records of Leicester, i, p. 395.

8 C. A. D., i, pp. I67-I68.

9 Ibid., i, p. 187 .

${ }^{10}$ H. M. C., Rep., 9, pt. I, p. 7 .

"I Hudson and Tingey, Records of Norwich, i, p. 257.

12 Ibid., i, p. 233.

${ }^{13}$ Stanley $v$. Mayor, etc., f. 3 I.

${ }^{14}$ C. A. D., i, p. 67.

15 Ibid., i, p. 7o.

${ }^{16}$ Hore, Wexford, i, p. 153.

17 H. M. C., Rep., 5, p. 503.

${ }_{18}$ Ibid., 5, p. 514.

${ }^{19}$ Ibid., 5, p. 505 .

${ }^{20}$ C. A. D., i, p. 105 .

${ }^{21} \mathrm{Ibid}$., i, p. I24. " J. le M. undertakes. . . as long as Marines lives . . to pay him I 2 marcs yearly . . .; and in return Marines releases to le M. the tenement he held of him for life." 
Perhaps a clearer idea of the discrepancy may be obtained from a comparison of the burgage rents with the rents in the boroughs. Early records of rents simple are not so abundant as might be supposed, for till a comparatively late period the burgess seems to have had a great aversion to this sort of rent, though he regarded it more favorably than he did a sale simple. He usually wanted something beforehand, or he transferred under feudal forms, and the tenement so granted was commonly inherited by the grantee's heirs. Furthermore the earliest rents were not rents of houses as the term is used today, but rents paid out of houses. Such rents were usually heritable, perpetual, and subjects of commerce in themselves. ${ }^{1}$ Rents simple can be found in the following list from 6 d. to $£_{4}$; perhaps an average would lie between 5 s. and ros. $^{2}$ The list is intended to be illustrative, but not exhaustive; it could easily be greatly lengthened.

\begin{tabular}{|c|c|}
\hline Borough & Rent Simple \\
\hline Basingstoke .... & IOS. ${ }^{3}$ \\
\hline Berwick, I $333 \ldots \ldots \ldots$ & $33 \mathrm{~s} .4 \mathrm{~d} .^{4}$ \\
\hline Bridgwater, 4 Henry VII & average $10 .^{5}$ \\
\hline Bridport, 53 Henry III... & $16 \mathrm{~d} ., 8 \mathrm{~s}^{6}$ \\
\hline Do., ig Henry VI .... & ${ }^{1} 3 \mathrm{~s} .4 \mathrm{~d} .^{7}$ \\
\hline
\end{tabular}

1 The same conditions held in German towns. See Arnold, Geschichte des Eigenthums, 2d section, especially p. 57 .

2 A rent of 12 marks seems excessive at such a town as Westmelne: there is possibly confusion in the record, or more than one messuage is included. At Leicester nearly every house paid capons or hens in addition to money; some paid hens alone (see Bateson, Records of Leicester, i, pp. $38 \mathrm{I}-396$; ii, pp. 200-203). The r2d. rent at New Ross is as low as rents went there. It was due from a schoolhouse, but the earl had stored his hay therein. gaining a barn but losing his rent. The rent of ros. 8d. at Oxford was not inclusive of all the consideration; " meat and drink . . . whensover she shall require it "must be found the lessor.

Where in the above list a single rent is given it is sometimes the only rent simple to be found in the sources quoted, but in most of the illustrations it is an average rent. When several are given for one town they are the lowest and the highest, with at times one or more to show the average. The differences were great between different towns, and between rents in the same town, differences which were not always due to the desirability or size (for size of the messuage see p. 100 ) of the tenements, but in part at least to the fact that many of the leases were heritable, especially those made by the monasteries; the dead hand was sure but it was slow.
3 R. $H$., ii, ,. 220.
6 C.I. II., i, P. 222.
- Scott, Berwick, p. $25 \mathrm{I}$.
7 C. A. D., i, p. 522 .
${ }^{5}$ C. I. M., Henry VII, i, p. I05. 


\section{Borough}

\section{Rent Simple}

Bristol, 7 Henry VII ................ Ios. ${ }^{1}$

Caermarthen, $1275 \ldots \ldots \ldots \ldots \ldots \ldots \ldots \ldots{ }^{2}$

Cambridge, ${ }_{3} 86 \ldots \ldots \ldots \ldots \ldots \ldots \ldots \ldots \ldots{ }^{20} .^{3}$

Carlisle, I Henry VII ............... 6s. $8 \mathrm{~d}$. for 3 tenements."

Colchester, $t$. Ed. III $\ldots \ldots \ldots \ldots \ldots \ldots \ldots$ 2d. $-6 \mathrm{~s} .8 \mathrm{~d} .{ }^{5}$

Coventry, 5 Ed. III $\ldots \ldots \ldots \ldots \ldots \ldots \ldots$ 40s. ${ }^{6}$

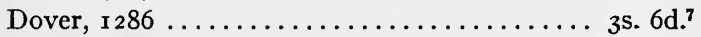

Dublin, $1280-90 \ldots \ldots \ldots \ldots \ldots \ldots \ldots \ldots$ 6d. $-40{ }^{8} .^{8}$

Durham, $1360 \quad \ldots \ldots \ldots \ldots \ldots \ldots \ldots \ldots .44$ s. $^{9}$

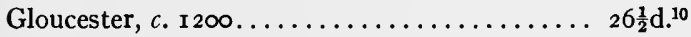

Do., $c$. I $230 \ldots \ldots \ldots \ldots \ldots \ldots \ldots \ldots \ldots$ s. $^{11}$

Do., $1455 \ldots \ldots \ldots \ldots \ldots \ldots \ldots \ldots$ 6s. 8d. -33 s. 4 d. ${ }^{12}$

Haverfordwest, 36 Henry VI $\ldots \ldots \ldots \ldots \ldots$ 2s. $-6 \mathrm{~s} .8 \mathrm{~d} .^{13}$

Hereford, 8 Ed. II . . . . . . . . . . $5 \mathrm{~s}^{14}$

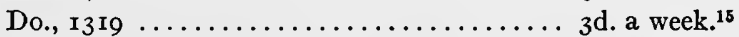

Ipswich, 3 Henry VII $\ldots \ldots \ldots \ldots \ldots \ldots$. Os. $^{16}$

Kingston-on-Thames. . . . . . . .

Leicester, $\mathrm{r} 289-90 \quad \ldots \ldots \ldots \ldots \ldots \ldots \ldots \ldots \mathrm{ss}^{18}$

Liverpool, $\mathrm{r} 346 \quad \ldots \ldots \ldots \ldots \ldots \ldots \ldots \ldots 6$ s. 8 d. ( $\left(\frac{3}{4}\right.$ of a tenement) ${ }^{19}$

Do., 22 Ed. III $\ldots \ldots \ldots \ldots \ldots \ldots \ldots \ldots, 4 s^{20}$

London, 2 John $\ldots \ldots \ldots \ldots \ldots \ldots \ldots \ldots \ldots \ldots \ldots \ldots \ldots{ }^{.21}$

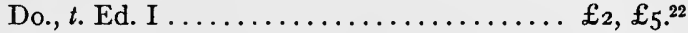

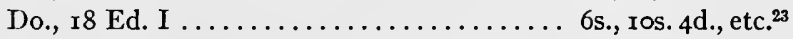

Do., 6 Ed. II $\ldots \ldots \ldots \ldots \ldots \ldots \ldots \ldots$ I3s. 4 d..$^{24}$

Do., 2 Henry VII $\ldots \ldots \ldots \ldots \ldots \ldots \ldots$ £6 for 3 messuages. ${ }^{25}$

${ }^{1}$ C. I. M., Henry VII, i, p. 294.

2 Daniel-Tyssen, Charters of Carmarthen, p. 75.

${ }^{3}$ H. M. C., Rep., i, p. 8I. ${ }^{4}$ C. I. M., Henry VII, i, p. 7 I.

5 Benham, Red Parchment Book of Colchester, pp. 70-71.

${ }^{6}$ H. M. C., Rep., I5, app., pt. Io, p. 137.

7 Statham, Dover Charters, p. 29.

8 Gilbert, Records of Dublin, i, pp. 100-106.

9 Brand, Newcastle, i, p. 216.

${ }^{10}$ Stevenson, Calendar of the Records of Gloucester, p. 82.

11 Ibid., p. 149 .

12 Cole, Rental of the Houses in Gloucester, pp. 9 et seq.

${ }_{13}$ C. A. D., iii, p. 53 r.

14 Madox, Firma Burgi, p. 257.

15 H. M. C., Rep., I3, app., pt. 4, p. 296.

16 C. I. M., Henry VII, i, p. II8.

17 Roots, Charters of Kingston upon Thames, p. I 5 .

18 Bateson, Records of Leicester, i, p. 390.

19 Picton, Records of Liverpool, i, p. I 2.

20 Baines, Liverpool, p. I54.

${ }_{21}$ Plac. Westmon. Abbr., p. 27, rot. 13, dorse.

${ }_{22}$ C. $I$. M., ii, p. 304.

${ }^{24}$ C. A. D., ii, p. 554 .

${ }^{23}$ Ibid., ii, p. 478.

${ }^{25} C$. $I$. M., Henry VII, i, p. I०4. 


\section{Borough}

Lynn, 3 Rich. I

Do., 6 Henry VI

Maldon

Manchester, i6th cent.

Morpeth, $1296 \ldots \ldots \ldots \ldots \ldots \ldots \ldots$ 6s.

Newcastle, 4 I Ed. III $\ldots \ldots \ldots \ldots \ldots \ldots \ldots \mathfrak{E}_{5}$ for 3 tenements. ${ }^{6}$

Do., 1470

Do., 3 I Henry VIII

New Ross, I280-8I

Norwich, 28 Ed. I

Oxford, 1279 .

Do., 47 Ed. III

Plymouth, 7 Henry VII

Plympton, 4 Henry VII

Rye, 28 Ed. I

St. Ives, ro Ed. II

Scarborough, I 279

Do., 1298

Shaftesbury, 1360

Southampton, 45 Henry III

Westmelne, 49 Henry III .

Whitby

Winchester, $\mathrm{I} 1 \mathrm{I}^{-1}-\mathrm{I} 5$

Do., 6 Henry VII

Woodstock, 6 IIenry VII

Wcrcester, 35 Ed. I.

Wycombe, 34 Henry VI

York, 1275

Do., 1296

1 Parkin, Lynn, p. I45.

${ }^{2}$ H. M. C., Rep., I I, app., pt. 3, p. I6r.

${ }^{3}$ C. P. R., a. 1401-05, p. 308.

- Court Lect Records of Manchester, i, p. 204.

${ }^{5}$ H. M. C., Rep., 6, p. 528.

${ }^{6}$ Brand, Newcastle, i, p. 75.

7 Ibid., i, p. 226.

${ }^{8}$ Ibid., i, pp. 407-409.

- Hore, Wexford, i, p. I 43.

${ }^{10}$ Stanley i'. Mayor, etc., f. I6.

17 R. $I .$, i, p. г $3 \mathrm{I}$.

18 I3rown, Vorkshire Inquisitions, iii, pp. 9I-93.

19 Mayo, Shaftestury, p. 37.

${ }^{20}$ C.I. M., i, p. 135.

${ }^{21}$ C. A. D., i, p. I 24.

${ }^{22}$ Atkinson, Whitby, p. 174 .

${ }_{23}^{23}$ D. B., iv, Liber Winton', ff. 3,7 .

${ }^{24}$ C. I. M., Henry VII, i, p. 255.
11 R. $I$. . ii, p. 797.

${ }^{12}$ H. M. C., Rep., 4 , p. 445.

it C. I. M., Henry VII, i, p. 195.

${ }^{15}$ H. M. C., Rep., 5, p. 503.

${ }^{16}$ C. A. D., i, p. $13^{6}$.

${ }^{25}$ C. I. M., Henry VII, i, p. 279.

${ }^{26}$ H. M. C., Rep., 8, p. 638.

"Ibid., 5, p. $5^{6} 4$.

${ }^{28}$ R. II., i, p. 119 .

? C. P. R., a. $\mathrm{1} 296$, p. 208.
${ }^{13}$ C. I. M., Henry VII, i, p. 290.

\section{Rent Simple}

$75 \mathrm{~s} .7 \frac{1}{2} \mathrm{~d} \mathrm{P}^{1}$

2os., 6s. 8d.2

Is. $6 \mathrm{~d}^{3}$

8s. 9d., 8s. 6d.4

$8 s .^{7}$

5s., 18 s., etc. ${ }^{8}$

Is., $4 s^{9}{ }^{9}$

Ios. for 2 tenements. ${ }^{10}$

5s.-44s. ${ }^{11}$

IOS. $8 \mathrm{~d} .12$

I Is. for 2 tenements. ${ }^{13}$

6s. 8d. for 2 tenements. ${ }^{14}$

$5 \mathrm{~s}^{.15}$

6s. 8 d. ${ }^{16}$

$95 .{ }^{17}$

35. -175.18

I3s. 4 d. ${ }^{19}$

8s. $8 \mathrm{~d} .^{20}$

12 marks. ${ }^{21}$

5s. 6d. ( $\frac{1}{2}$ of a tenement). .2

$£_{4} 6 \mathrm{~s}^{23}$

6s. for 2 tenements. 24

8s. 6d.25

I5s. $2 \mathrm{~d} .^{26}$

6s. 6d..$^{27}$

4 marks. 28

2s. 4 d..$^{29}$ 
Some of the rents in the list are the sum of four or five different rents paid to as many receivers thereof. Gifts of rents to religious foundations were frequent, too frequent; every important borough in England seems to have had many tenements therein which were burdened with rents to the religiosi, though the burden lightened as values rose. ${ }^{1}$ Parallel conditions existed in the cities of Germany, with this difference, however, that the German burgher's 'gift,' as is shown by cases at Basel and elsewhere, was usually the interest on a loan made to him by the Stiftung; the English burgess's gift was commonly the outcome of credulity and superstition. Not always, however, as the following parallel of the Basel practice shows:- r260-70, "grant by P. C. to R. D., vicar of Southstoke, in consideration of 12 marks in pennies, of a perpetual yearly rent of $12 s$., payable quarterly out of the house which T. S. held of him in Bath." ${ }_{2}$ Such a transaction is uncommon in the English records. Money played a less important part in the agricultural English boroughs than in the commercial Rhine towns. The grant of the quotation shows a lower rate of interest, for this case at least, at Bath than at Basel. In the former it was $\mathrm{r}$ to $\mathrm{I} 3 \frac{1}{3}$, in the latter $\mathrm{I}$ to $\mathrm{r}^{3}$, though the former ratio does not necessarily show the ruling rate of interest in the English city. When many rents were bought and sold in purely commercial transactions, a common practice in the Rhine towns, the rates of interest which such loans must bear did not vary greatly in amount. The seller of a perpetual rent was really a borrower of capital; the buyer was an investor. The matter was of importance to burgage tenure because the low landgable and its stability, together with the mobility of the tenement, made the burgess's credit good. ${ }^{4}$

Perhaps the commonest fashion of transfer in the early part of our period was, as mentioned before, to combine sale (a sum

1 A heavier burden, not only on national but on urban finances, lay in the mediate or immediate ownership of burghal property by religious foundations (see Gross, "Mortmain in Mediaeval Boroughs," in American Historical Review, July, I907).

2 King and Watts, Municipal Records of Bath, p. xvii.

3 Arnold, Geschichte des Eigentums, pp. $117,245$.

- Arnold in his Geschichte des Eigentums has treated this matter in detail. 
paid 'praemanibus') and rent. Such rents bore no constant proportion to the amounts paid beforehand, and even allowing for the greater purchasing power of money at that time, they were often insignificant. On the other hand many cases can be cited where this rent was equal to and sometimes greater than the amount paid 'praemanibus.' Nor were the retained rents always in money; hens and arrows, gloves and roses, spurs and cloves, pepper and pigeons, ${ }^{1}$ and other articles equally incongruous served to satisfy the terms of many grants. Records of transfer combining sale and rent show prices paid from 20s. to I Io marks, with an average of less than $50 \mathrm{O}$.; rents retained with these vary from $2 \mathrm{~d}$. to one mark, most of them between Is. and 3 s. $^{2}$

1 H. M. C., Rep., 9, pt. r, p. 47, London: a rent of "two doves, for the most part white, shut up in a wooden box."

2 The order in the following list is ( $\mathrm{I}$ ) the borough, (2) price 'praemanibus,' (3) retained rent, (4) source:

Bridgwater, ? $t$. Ed. I 20s. and a pig is.

Cambridge

Dartmouth, $t$. Ed. I

Dartmouth, $t$. Ed. I

Dartmouth, $t$. Ed. I

Dartmouth, $t$. Ed. I

Exeter, 7 Ed. II

Ipswich

Kenfig, 1270-79

London, 1228

London, c. $125^{\circ}$

London, c. 1267

London

Oxford

Rye, 1258

Rye, 34 Ed. I

Wallingford, $t$. Ifenry III 4 Os.

Wallingford, t. Henry III roos.

Wallingford, t. IIenry III 40 os.

Wells, c. I 200

Worcester, t. Eil. I

Wycombe, $t$. I.d. I
$7 \mathrm{~s}$.

$2 \mathrm{~s}$.

20 .

33s. 4 d.

2 I marks

$$
\text { ? }
$$

40 .

20 .

110 marks $2 \mathrm{~s}$.

60 marks Is.

80 marks I3s. 5 d.

36 marks Id.

2os. 4 s.

13s. 6d. 5 d.

4os. 8 s.

I pr. gloves

I clove

$6 \mathrm{~s}$.

5 is. and 'a golden

fermail' Ios.

$\mathfrak{L}_{5} \quad 3$ s. $6 \mathrm{~d}$.

4os. $\quad 35$.

$3 \mathrm{~s}$.
H. M. C., Rep., 3, p. 311.

Ibid., I, p. 70.

Ibid., 5, p. 599 .

Ibid., 5, p. 599 .

Ibid., 5, p. 599 .

Ibid., 5, p. 600 .

s.after 29 yrs. Ibid., 5 , p. 605.

C. A.D., ii, p. 176 .

Clark, Cartae Glamorg., iii, p. 529 .

C. C. R., i, p. 79 .

C.C.R., i, p. 368 .

C.C.R., ii, p. 77 .

H.M.C., Rep., 9, pt. 1, p. 10.

Ibid., 4, p. 445 .

Ibid., 5, p. 503 .

Ibid., 5, p. 50.4 .

Hedges, Wallingford, i, p. 342 .

Ibid., i, p. 344 .

Ibid., i, p. 345 .

II. M. C., Rep., 3, p. 360.

Ibid., 8, p. 638.

Ibid., 5, 1. 559 .

At Bridgwater the grantor's wife opposed the sale. The grantee's pig removed her objections. 
The subject of hens as a part or the whole of rents was once considered to be of some significance in connection with theories of the origin of free urban tenure. ${ }^{1}$ Such rents existed at widely separated boroughs in England; Leicester is the town where they most abounded. ${ }^{2}$ At Tutbury and Uttoxeter, erstwhile manors, the charter (or customal) states that "the burgesses ... shall pay noe ... rent hens" ${ }_{3}$ but this refers to the rents of assize or landgables. The boroughs whence the records come extend from the channel up the east coast and into Staffordshire. Leicester was, no doubt, mainly a farming community, but Dover was not, nor was Ipswich. This rendering of hens, however, is certainly nothing but a survival of what was once a convenient method of paying rent.

Other things than hens figured in rents in the boroughs, particularly pepper and cummin, the receivers of such rents being usually ecclesiastics ${ }^{4}$ and the amount of either condiment due from one tenement commonly one pound, ${ }^{5}$ though in 1279 a tenement in Cambridge rendered a penny, a rose, and a grain of pepper. ${ }^{6}$ The worth of a pound of cummin seems to have varied

1 Arnold based his theory of 'domainial' origin mainly on hens; see Geschichte des Eigentums, p. 35. Keutgen shows them to be merely a convenient form of rent; see Deutsche Stadtverfassung, p. I 20.

${ }^{2}$ Bateson, Records of Leicester, i, p. 183: Isabella " remitted and granted and quit-claimed for ever . . . 3d. and a hen of yearly rent-charge which . . . W. . . was wont to render to her from his chief messuage." See $i b i d ., \mathrm{i}$, p. 383: 6d. and 2 capons, a. 1250; ibid., i, p. 385 : one hen or $\mathrm{Id}$. These Leicester records so teem with hens that one looks for eggs in the rent (they were common in manorial services). Most of the rents in Leicester contain cocks, capons, or hens, and some consist of hens alone.

Hen rents are found in a few instances at Hythe (H. M. C., Kep., 6, p. $5^{\mathrm{I} 3}$, a. I334), Dover (Statham, Dover Charters, p. 5I: " 2 s. and 6d. and one hen of free and perpetual annual rent," a. I342), Southampton (H. M. C., Rep., 6, p. 553, c. I273), Nottingham (Stevenson, Records of Nottingham, p. 366), and Ipswich (C. A. D., ii, p. 222: "gd. and a cock and hen "; ibid., iii, p. 3). Elsewhere than at Leicester rents of this sort are commonly payable to monasteries. This may be due to old custom or to the monks' fondness for poultry.

3 Mosley, Tutbury, pp. 367-368.

4 Gilbert, Records of Dublin, i, p. 94, a. 126r. St. Mary's Abbey rented one of its messuages in Dublin for money and a pound of cummin.

C. I. M., ii, p. 478 , a pound of cummin among the bishop of Ely's rents in London in $18 \mathrm{Ed}$. I. - In $C$. A. D., i, p. $4 \mathrm{I} 7,6 \mathrm{Ed}$. III, the same term occurs.

5 Sometimes half a pound. C. A. D., i, p. 186 ( 5 Ed. I, London).

6 R. H., ii, p. 370 . 
between a penny and fivepence; ${ }^{1}$ a pound of pepper was of greater value. $^{2}$ Gloves appeared frequently as parts of rents, white gloves as a rule, or in their place a penny, ${ }^{3}$ though in Coventry a farthing was the price. ${ }^{4}$ In Oxford and London, gilt spurs, whose value was set at sixpence, were often rendered as rent. ${ }^{5}$

In all these cases the nature of the annual return is easily understood. Spurs, gloves, and that sort of thing were useful and valuable, and the grantee commonly had the option of rendering money in their stead. A more frequent form of nonmoney rent, however, and one not easy to explain on a basis of common sense, was a rose or a clove ('clavum gariophili'). A 'red rose on St. John's day' was not of much worth, and usually it was the only rent which the grantor retained; such rents were perhaps more the mode in London than in the little farming boroughs. Undoubtedly one reason for asking nothing but a rose was the wish really to sell or give a tenement while still retaining its lordship, but a nominal money-rent would have answered as well. ${ }^{6}$ As rents in terms of roses seem rare in the country, ${ }^{7}$ it appears that this particular sort of rent is

1 C. C. R., ii, p. $77, a .1267$, a rent of a pound of cummin might be commuted for 2 d. in London; ibid., ii, p. I69, $a$. 1270, for rd. at Newcastle. Sometimes a pound of cummin was valued at 4 d. (C. A. D., ii, p. 4o).

${ }^{2}$ C. A. D., iii, p. 266: 7d.

${ }^{3}$ Gilbert, Records of Dublin, i, p. 97, a. 1264; Clark, Cartae Glamorg., i, p. 202, a. 1305 .

4 H. M. C., Rep., I5, app., pt. ro, p. I 29. Glove and pepper rents, sometimes alone but commonly in connection with money rents, seem to occur oftenest at Southampton (C. A. D., ii, p. $3^{86}$ ), but they can be found all over England, or at least as far north as York (Widdrington, A nalecta Eboracensia, p. 253).

${ }^{5} C$. C. R., i, pp. 67-68, a. 1228. In one instance the spurs were due from Hubert de Burgh to be paid out of a tenement in London which the king had given him; in another the payment was due from a citizen.

6 Een communities took rose-rents. At Ipswich in 1336 Horswade mill was burned and the miller's son undertook to rebuild it at his own clatrge. The townsmen then gave him a lease of it for eight years along with their meadow called Oldenholm. he to render " a redd rose at Midsummer" (Bacon, Anulls of I pswiche, p. 62). An ear of barley would seem more appropriate.

7 Bracton writes of services of gloves, wax, pepper, cummin, sandals, etc. (De legibus, i, p. 278) as quite common in the country, but neither he nor Britton mentions roses. See, however, Clark, Cartae Glamorg., i, pp. r53, 179 (" unam rosam in m(nse Junii "), is $5,204$.

At Mannheim, I'ennsylvania, a German community, in 1772 , a burgess granted land to a church for a perpetual yearly rent of one red rose in June, if demanded. 
due, not to imitation of feudal custom, but to the well-known poetic grace and romantic nature of the mediaeval English burgess.

These rents were commonly heritable and perpetual, and those who paid them were consequently freeholders. There were, however, in addition to these and tenants for life, tenants of other sorts, - on long lease, at will, in remainder, by ' courtesy of England.' 1 Records of these modern methods of leasing are scanty in the early part of our period, perhaps the first definite reference thereto being at Winchester. ${ }^{2}$ In some cases borough customals or charters recognized the right to lease, as at Cardiff, ${ }^{3}$ Leeds, ${ }^{4}$ Bakewell, ${ }^{5}$ and Manchester. ${ }^{6}$ These places, however, are boroughs of late formation and merely mention in their charters what had the sanction of long use in the important towns. ${ }^{7}$

During the twelfth and thirteenth centuries grants were many and leases few ${ }^{8}$ with the fourteenth century leases increased, and at the close of the middle ages they seem to predominate over other forms of transfer. ${ }^{9}$ Yet all through the middle ages there appears to have been little leasing for short periods, though London especially, in this as in other conditions which approach

1 The tenement which a wife brings at marriage remains to the husband for his life if the wife should die before him, a child having been born of the marriage. See Hudson and Tingey, Records of Norwich, i, p. I56, "according to the courtesy and custom of the realm and this city "; Markham, Liber Custumarum, p. 22, Northampton; C. I. M., Henry VII, i, p. 382 , London.

${ }^{2}$ D. B., iv, Liber Winton', f. 9 : " G. clericus tenet . . . ii mansuras de lessam "; this differs from a grant with a rent in that the tenements are not held by the indweller.

3 Matthews, Cardiff Records, i, p. I2. A burgess who had two burgages might lease one.

${ }^{4}$ Wardell, Leeds, app., p. iv. The same privilege as at Cardiff.

5 H. M. C., Duke of Rutland, iv, p. 4I, charter in I 286.

6 Tait, Mediaeval Manchester, p. 66, charter in r $30 \mathrm{r}$ : " quilibet burgensis potest tradere burgagium."

7 At Norwich a clause in the customal forbade a lessee to sell (Hudson and Tingey, Records of Norwich, i, p. 16r): the lease in this case must have been for a long term.

8 Records of leasing are abundant in such of the town archives as have been transcribed, the Calendars of Inquisitiones post mortem, etc.

9 Of the earlier leases some were in perpetuity, as at Dublin (Gilbert, Records of Dublin, i, p. I03, a. 1284); some were for terms of years, some for three lives, ás at Bath (King and Watts, Municipal Records of Bath, p. xv, a. 1336). 


\section{modernism, formed a marked exception. ${ }^{1}$ Records of leases} for short terms of years are rare, ${ }^{2}$ but whether the leases were as rare as the records may be questioned. Many leases may have been effected verbally; in such cases evidence of their existence would be preserved only through ulterior circumstances, especially those which called for inquisitions concerning real property. Such a proceeding at Scarborough illustrates this possibility, perhaps too well, for it seems exceptional. ${ }^{3}$ 'The importance of this part of our subject lies in the fact that leasing as distinguished from holding had the sanction of law in the boroughs before its recognition by the land law of the country at large. ${ }^{4}$

1 See Riley, Munimenta Gildhallac, i, pp. xxxvii f. Early in the fourteenth century houses for letting, and 'flats' at that, were fairly numerous. Their average rent was about 4 os. a year. When the rent was 4 os. or lower three months' notice was required from either landlord or tenant. When the rent exceeded this amount the notice was six months.

Possibly the tenements which formed a subject of inquiry in 5 Henry VII (C. I. M., Henry VII, i, [). 235) were of this sort; they were each worth 40 . to 6os. "yearly, when let." At Hereford one tenement was let for 3 d. a week (I. M. C., Rep., 13, app., pt. 4, p. 296).

2 The Appendixes to the H. M. C. Reports contain a comparatively small number.

${ }^{3}$ Brown, Iorkshire Inquisilions, iii, pp. 91-93, a. 1298. A burgess of Scarborough had free tenants at 75 ., etc., and also tenants at will who held burgages at Is. 6 d., 9s., 2s., etc., to the number of 20 or more. The 'free tenants' were freeholders, the tenants at will might be evicted by the landlord at his will or might leave at their own.

4 'The 'termor' of the country had no legal recognition till about 1240 , when the writ quare ejecit infra terminum made its appearance. There was no Assize of Nowel 1)isseisin for a termor; he was never seized, he held no free tenement.

In a devise of 1485 at Colchester occurs the phrase " tenement . . with the rentiar attiched to the same" (Benham, Red Paper Book of Colihester, p. I02); two other "rentars,' "which . . John Best inhabited and oceupied" were devised in the same will. 'Three renters adjacent to' another messuage in the same place are spoken of in 5 Henry IH (C. I. M, Ilenry VII, i, p. 208). These "renters' may be houses for rent. 1)u (ange gives rentar = rentier, but in modern French the latter means a holder of the nation's bonds.

There were slight restrictions on leasing in a few horoughs, applicable, however, often to only certain messuages in any one place. At Cardifi (Matthews, Cotrdiff Records, i, p. 12), and Lecels (Wardell, Leeds, app., p. iv) it scems probable that a burgess was not supposed to lease unless he had more than one messuage. At Dinhered tenants of the town must get permission to sublet (Feter, Laumceston, p. 174). See also (illbert, Records of Dublin, i, pp. 103, sor. At Rhudedlan letting "is said to have been forbidelen" (Tait, Mediuezal Munchester, p. og). See, for conditions as to leasing at Northampton, Markham, Liber Custumarum, p. 25. 
It seems a matter of course to suppose that a granted rent was wholly the grantee's, but the records of such grants, particularly those of an early date, show that he often got only a part, and sometimes a very small part, of such a rent, the rest going to others, especially the religiosi. After the passage of the act De Viris Religiosis in I279, grants of rents, out of which second rents practically equal to the first rent must be paid to an abbey or a church, increased in number, though the grantor's relations did not always pass unnoticed. No matter where paid these 'rent-charges' form a very important feature in the economic history of the boroughs. They were a subject of traffic as well as the tenements from which they were paid, and afforded on a small though nimble scale a sort of negotiable securities, subject, however, to the same conditions which governed the transfer of realty in any particular borough. ${ }^{1}$

It has been shown that a large amount of real property in the boroughs passed into the king's hand, a small part as escheat but a large amount as forfeiture. The usual practice of the central government was to give or sell the tenements thus acquired, unless there was some agreement concerning them between the king and the borough. When the king granted them, however, he usually retained a rent and sometimes he retained and rented them, thereby becoming a landlord in the borough. The town bailiffs commonly acted as his agents in such cases, collecting the rents and accounting for them at the Exchequer and not in the Firma Burgi. ${ }^{2}$

1 It is hardly needful to add that these rents were chargeable only on perpetual rents or long-term leases. Many of them were dry rents (redditus sicci, rentssecks) on which no distress might be levied.

Frequent as such rent-charges are in many English boroughs, they are very unequal in number to corresponding grants in the towns of the upper Rhine. See Arnold, Geschichte des Eigentums, 3d section.

2 At Berwick in 1333 the chamberlain (Berwick had just been conquered from the Scots) accounted for about $£ 60$ of rent from "divers tenements escheated to the King " (Scott, Berwick, pp. 249-250); at Liverpool in 1346 the bailiffs " answered for $6 \mathrm{~s}$. $8 \mathrm{~d}$. of rent of three parts of a burgage which fell into the king's hand by the death of ..." (Picton, Records of Liverpool, i, p. I2). In 12 Ed. IV the bailiffs of Winchester "debent viii d. per annum de redditu . . . domorum quae fuerunt Judaeorum" (Madox, Firma Burgi, p. I9); in I280-81 the Provost of 


\section{The Nature of the Burgage}

What was this messuage or burgage whose nature so far we have assumed to be well known? Was the term burgage or its equivalent applied to the land, or to the house thereon, or to both? A definite answer is hard to give, so much depends on time and place; as long as the mediaeval English burgess knew very well what a burgage was, why should he waste thought on abstractions or on logical definition? It has been suggested that "probably the term [burgagium] at first referred primarily to the land, afterward to the house." I 'Burgagium,' however, was not a term of common use; in the early part of our period it was used hardly at all; the records concern 'messuagia' or 'tenementa' but not burgages. Nor does the common use of the terms messuage and tenement follow the order suggested, for in the older boroughs their primary application is sometimes to the land and sometimes to the house, and the terms are so used, each borough having its own fashion, all through the middle ages. ${ }^{2}$

Generally speaking and anticipating, the 'burgage' was the land, or the house, or both; it contained all these meanings and any one of them, depending on the place and, to a small extent, the time; the result was the same, a burgage was almost anything 'holden in free burgage' on which or in which it was possible to live, and which in the older boroughs might be any-

Rospont (Ross; Hore, II exford, i, p. 143) and in I 30 r the burgesses of liskeard (Allen, Liskeard, p. is) accounted for such rents.

From the charter to Norwich of 1403 , the mayor then being escheator ex officio (the rule when a borough was incorporated), it appears that his deputy, though he must "account in the Excheruer for the profits . . . shall not be compelled to go out of the city to account" (Blomefield, Norfolk, iii, pp. 121, 122).

Inirerquenty the holder of an escheated or forfeited messuage must jay the rent directly to the royal finaneial officials, at at Scarborough, where a burgess who had a messuage of this sort paid the rent "by his own band at the king's exchecpuer every" year" (Brown. Jurkshire Inquisitions, iii, p. 93), and possibly at London (C. C. R., i, 1 ). 3(1) $7,(2.1251)$.

1 Gross, Gild Werchant, i, p. 71, note 3 .

= Sone of the whest records, as Liber Winton', use domus and (rarely) terra as a name for the tenenent. In a few boroughs the term 'burgage' seems to pass from land to house. 
thing between and including the cellar and the attic. The term burgage was, of course, applied first to land when a borough was created by charter where no town existed before, as was the case with many boroughs in Ireland. ${ }^{1}$ When a house was built on an allotment of this land it too was a burgage ${ }^{2}$ and both were called a burgage. ${ }^{3}$ When a burgage or messuage was reduced to its lowest terms there was, of course, nothing left but the land, also on this the landgable lay. This shows the primary conception of the burgage before the age of burghal records; it must not be forgotten, however, that hawgable too comes down from the same shadowy age. ${ }^{4}$

1 In all the boroughs having Norman customs the primary idea of the burgage must have been a certain amount of land. In such places the number of the burgages remained the same all through our period.

2 Not a chattel, a distinction of importance; see pp. I44, n. I, 208.

3 As in the Earl of Pembroke's charter to Wexford in 1317 , "liceat eisdem burgensibus de tenementis suis que tenent in burgagiis suis, . . . disponere sicut sibi melius viderint expedire, sive edificia sive ortos sive virgulta sive alia "(Chartae Hiberniae, p. 47).

At Preston he who wished to become a burgess must get his " burgage from the mayor." When his burgage "shall be a void place, the mayor shall admit him, so that he shall erect his burgage within forty days upon a forfeiture " (Hardwick, Preston, p. 259); a burgage must be twelve feet in front (ibid., p. 260).

${ }^{4}$ The prominence of the idea of land is apparent in the records of transfer of many boroughs; "Sciatis me dedisse . . . burgagium meum [in Kenfig] . . . et unum masagium in Cardif super quod domus sua est " (Clark, Cartae Glamorg., iii, p. 166, c. 1250); this distinction between burgage and messuage is a distinction without a difference. The restriction of 'burgage' to a tenement which entitled its holder to a vote in parliamentary elections did not exist in the middle ages.

The burgage was the land at Weymouth, "dwelling [on] or having burgages" (Moule, Weymouth, p. I8). At Scarborough in 3 Ed. I the jurors said that the profits of certain mills and a house " belong and ought to belong to the demesne of the said burgesses .... and not to the farm of the same town; saving to the King the ancient gabelage from the tenements on which the three mills are placed, that is for the site of each, 4d.; and saving to the King 6d. a year from the house bought" (Brown, Yorkshire Inquisitions, i, p. I64).

The idea of land ruled at Eton in 1307 (C.A.D., i, p. 350, "half a burgage with its houses "), Kingston-on-Thames, $t$. Ed. I or Ed. II (ibid., i, p. 385 , "tenement . . . with a house built thereon "), Bykes (C.A.D., i, p. 396, "two burgage tenements . . . with the buildings thereon." This obscure borough of the musical name is in Bedfordshire), London (C. A. D., i, p. $397,35 \mathrm{Ed}$. III, "two tenements with cellars, shops, and solars," equivalent to "two tenements with the buildings thereon '). See also H. M. C., Rep., 8, p. 269, 5 Rich. I; C. A. D., iii, p. 295, 
Whether or not the land within the ditch or wall was more prominent than the house there could be no question of its prominence without, for agriculture was the chief industry in most of the English boroughs throughout our period. Few boroughs were solely commercial except a small number of sea or river ports, and in some of these fishing and piracy must be included under the name of commerce. Oxford, Cambridge, and a few other centers of that sort excepted, the inland boroughs were almost wholly agricultural, what little they did in the trading way being done at the usual fairs. Under these conditions land would be needed; the burgesses, like the people of the country, must and did have land in the common fields or arable, and pasture land as well. One can readily see how much some boroughs must have resembled vills. It is this resemblance which makes it so easy for vills to grow into boroughs, and sometimes so hard to draw the line between borough and vill. Perhaps as great a difference as any lay in the destination of the lands in the common fields.

In the vill, in general, each acre, or whatever the division of land might be, was connected with, though not inseparable

${ }_{2}$ Henry IV; H. M. C., Rep., 9, pt. 1, p. 208, a. 1422; C. A. D., i, p. Io0, I I Henry VI; C. I. M., Henry VII, i, p. 434, 10 Henry VII, etc.

Burgage is used to include both land and houses at Canterbury (Elton, Tenures of Kent, p. 171), Ipswich (C.A.D., ii, p. I 76, "houses with the soil "), London (C. A. D., ii, p. 7), Cambridge, and Nottingham (H. M. C., Rep., I, p. 105, " all houses, edifices, structures, as well under ground as above ground ").

The house idea seems to prevail at Winchester (D. B., iv, Liber Winton', ff. $4^{\text {b, }}$ 7, etc.), Gloucester (Stevenson, Records of Gloucester, pp. 83, 150; Cole, Rental of the Ilouses in Gloweester, 1455, Pp. 5-13), Bridgwater (H. M. C., Rep., 3, p. 3I I), Kenfig (Clark, Cartae Glamorg., iii, pp. 529-530), 'burgus de Wych' (R. II., ii, p. 285), Southampton (H. M. C., Rep., 1 I, app., pt. 3, p. 57), Berwick (C. P. R., a. 1297 , P1). 227,247 ), Rye (H. M. C., Rep., 5, p. 506).

In some newly founded boroughs buildings must be erected within a certain time under penalty of forfeiture, as at Preston (IIardwick, Preston, p. 259). At Inistiogue 'quilibet burgensis post primam seisinam terre sibi factam in eadem villa residenciam per propriam personam vel per interpositam infra tres septimanas faciat vel imperpetuam tenementum suum amittat' (Gale, Corporate System of Ireland, app)., p. xiii).

London affords instances of almost anything. See C.A.D., i, p. 200 (for a modern ground rent, t. Ed. II); ibid., i, p. 426; H. M. C., Rep., 9, pt. I, p. 18; C. I. M., i, p. 382 (a wharf is a tenement); and Madox, Firma Burgi, p. 118 , "messuagium sive tenementum . . ruinosum et nullius valoris." 
from, some particular toft, and whoever held one held the other, although no two holdings need be equal. Most villeins were farmers; often a particular toft with its land may have descended through many more unbroken generations in one villein family than the lord of the manor could number in his own. Unless the holder of a toft happened to be a smith, or wheelwright, or what not, there must be in conjunction with his house land enough for him to live by; in that sense there was a limit to inequality of holdings. The main feature, however, is not the amount of land and toft, but the connection between them. Was this the case with the boroughs? Did 'burgage' imply not only the land with its house in the borough, but also that there was land connected therewith in the common fields? For the larger and more commercial towns, which it must not be forgotten had their fields as well as the smaller agricultural boroughs, it certainly did not, even though it may sometimes appear as if it did. ${ }^{1}$ In these boroughs, the records of land transfer show that land in the arable was a separate subject of traffic. It might pass with the messuage proper or might be sold independently, and the quantity of land connected with particular messuages varied greatly in amount. ${ }^{2}$ Land in the arable was held under burgage tenure, but did not form part of the burgage tenement.

Such was the case in the boroughs by prescription; boroughs created by charter need more particular treatment. Such places were of two sorts, the vill which got a charter as a liber burgus and the newly founded town: in the first class were most of the baronial and ecclesiastical boroughs of England, in the second those of Ireland and the Welsh marches. In the former the charter commonly allowed all lands held by the new burgesses to come under burgage tenure, in which case these lands would be held and treated as in the ancient boroughs, all of whose privileges the recently enfranchised manors were anxious to attain.

1 As at Norwich: "ten acres of arable land to that messuage appertaining," a large amount for one messuage in a borough so commercial as Norwich (Stanley v. Mayor, etc., f. 5).

${ }^{2}$ See R. H., ii, pp. $35^{6}$ et seq., and Maitland's comments in his Township and Borough. 
In some few of the English baronial boroughs the charter limited the amount of land to be held in free burgage, ${ }^{1}$ but the common practice was as previously stated, a practice and condition very clearly illustrated in Henry de Lacy's charter to his men of Congleton, ${ }^{2}$ which was, as were all towns of its character in England, a borough created by charter but not a created borough.

In the created boroughs of Ireland and on the Welsh marches it was necessary that there should be some limit to the amount of land which should come under burgage tenure. In England outlying manors and natural development generally fixed the bounds of the boroughs; in Ireland and the marches the world was all before them. It was manifestly out of the question to allow to the tenure all land that a burgess might acquire, so an elastic but definite limit was found in the amount of land with, and not a part of, each burgage. ${ }^{3}$

1 Leeds affords apparently the only important instance of this practice. In 1 208, Maurice Paganel's charter gave " to my burgesses of Leeds . . . liberty and free burgage, and their tofts, and with each such toft half an acre of arable land . . . , for each such toft and half-acre, I6d.' (Wardell, Leeds, app., p. iv). It seems that here the half-acre was considered an integral part of the messuage; the rent lay on both it and the toft, a condition, however, which existed at no other borough, except possibly lenbigh. Leeds was a borough created by charter but was not a created borough; its men became burgesses and their tofts burgages, but they must have had more land than that spoken of in the charter. The sites of their houses and half an acre with each, however, were all that came under the tenure. if the charter be interpreted literally. Morpeth seems to have resembled Leeds in some ways but the acres appear to have borne a small rent, Id. for 3 acres (H. M. C., Rep., 6. p. $527, a, 1_{28}$ ).

2 Ifead, Congleton, p. 34, "we will . . . that the aforesaid Burgesses . . . may have and hold their Burgages and the lands to the Burgage belonging, and also the lands within the said Lordship which can be reasonably appropriated and rented . . . cery burgage for col. yearly and every acre of land for r zll."

3 The sane methol that was followed in Ireland was sonetimes used in England. At Agardaley. "each [burges] may have with his burgage three acres of land, namely two acres arable and one to builel a burgage house upon" (Mosley, Tutbary, app. viii, p. $\left.3 \$_{3}\right)$. There is no separation between the rents of acre-strips and burgage flots. as at Congleton and elsewhere; the rent, isd., is apparently due from both land and site of house. In such a case it wats borne by the latter.

At last (irinstead in Susex there were, as late as the midelle of the soth century, 4 s burgages and +7 , fortlands." or lands in the common folds; the burgage rent was 3 d. and each portland 3 d. (Hills, East Grinsteud, pp. ro and $40-41$ ). When the rental was drawn up there were burgitges without portlands and some with more 
These boroughs of shilling rents and lands assigned, whether in England or in Ireland, whether the burgage alone bore the twelvepenny rent and the land nothing as in the latter country, or whether the acre strips had each its own rent in addition to that on the burgage as in the former country, afford examples of the influence which a Norman ville, always obscure and vanished long ago, exerted to a greater or less extent on many of the boroughs of Ireland and on unimportant boroughs of the west of England. This is a subject for later treatment, ${ }^{1}$ but there is at least one borough whose tenurial customs, though reflecting foreign influence, were certainly not imitative of those of Breteuil. The town in question, Denbigh, seems to have combined English tenurial custom with that of a bastide of southern France. For this place there were two names and two charters, the first in $125^{2}$ was to the 'town of Gannoc.' ${ }^{2}$ Then came the Welsh and Gannoc was as if it had never been. The refounder, Henry de Lacy, Earl of Lincoln, from which shire came probably most of his men, granted most of the burgages

than one; probably at the date of the charter each burgage had the same connected amount of land.

At Llandovery the rent of a burgage was $12 \mathrm{~d}$. and of each acre in the fields I $2 \mathrm{~d}$. (Parliamentary Papers, I835, xxiii, p. 301); at Ruyton in $2 \mathrm{Ed}$. II each burgage paid I 2 d. and each acre 4 d. (ibid., xxvi, p. 2858). At Altringham the custom is as at Congleton, the rent, I $2 \mathrm{~d}$., covers both burgage and land in the fields: "unusquisque burgensis teneat burgagium suum duarum perticarum terrae in latitudine et quinque in longitudine cum una acra terrae integra in campis pro duodecim denariis" (ibid., xxvi, p. 2574).

At Ross each house had four acres of land (Hore, Wexford, i, p. I53), at Rathcool the amount was the same (Gale, Corporate System of Ireland, app., p. x, "singulis eorum quatuor acris terrae in messuagio, prato, et terra arabili"), at Inistiogue it was three acres (ibid., p. xii, "cum tribus acris"), while at Rathmore most burgesses had seven acres each: "quatuor viginti et quinque burgagia cum pertinentibus, viz. ad unumquodque burgagium septem acras terrae et frontem, et undecim burgagia ... dimidiam acram terrae et frontem" (ibid., p. xix). The 'frons' is the building lot or its frontage within the ditch or wall.

At Oswestry the rent of a burgage was I2d., and of three acres, the amount with each burgage, I2d. (Tait, Mediaeval Manchester, p. 65).

1 See below, pp. I66-1 72 .

${ }^{2} C$. C. R., i, p. 378 . The charter made the place a free borough with the customs of Montgomery. Each burgess got "within the said borough half an acre to build and make a curtillage, and without the borough two acres of arable land," rent of all $24 \mathrm{~d}$. 
in this wise, "one burgage in Denbigh within the walls, and one curtilage in Denbigh without the walls "; sometimes a burgage was accompanied by an "oxgang of land with the appurtenances in Astrad Canon" or some other near-by locality, but usually the amount of land in the fields was not specified. ${ }^{1}$

There is some resemblance between this plan and that followed in Ireland, where each burgess received an allotment of from three to seven acres and usually a building lot as well. But whether the burgages were supposed to be the total amount of land or not makes no difference in the character of the borough. Each house did not stand apart from the rest on its three to seven acres. The boroughs of Ireland were mostly walled to guard against attacks by the Irish, the houses therefore stood fairly close, the 'acres' were in the fields, 'prata et terrae arabiles.' 2 The founders of these towns might have drawn a distinction between lands and burgages, as was done at Congleton and other English baronial boroughs. They did not, however; they were creating boroughs and importing burgesses; their towns were the villes newes or Freistädte of Ireland, Congleton was in peaceful England. It was the simplest plan to give the burgesses each a few acres and let them huddle their houses as close as they wished. ${ }^{3}$

1 See Williams, Denbigh, pp. 302-305. The burgage rent was Id., in a few cases 4 d. to rod. For the bastides see 1 . Curie Seimbres, Essai sur les Bastides, p. I66. In such places there were three sorts of lands: first, the comparatively small and equal plots within the walls; second, the livisions close around the walls, "ils avaient pour destination l'établissement de jardins potagers;" and third, the fields. So in Denbigh there were the three sorts of land within the bounds of the borough; though not every burgess may have had land in the fields, he always had his garden plot beyond the wall. It seems probable that de Lacy had served in Guienne.

${ }^{2}$ Miss M. Bateson seemed to hold the opinion (English IIistorical Reviea, xvi, p. 34x) that each burgage in the strict sense was of three or more acres, $i . c$. , that cach hurgess had this allotment around his house. A truly defensible place such a settlement would be.

In one sense the burgage seems to include the land, for the ral. rent is the rent of the whole grant to each burgess. Yet it lies on the burgage proper; otherwise the acres would have been inseparable from the burgage, a condition which so many transfers of lands in the fields show not to have existed.

3 Often the charters granted building lots exclusive of the lands assigned; the size of the former was never specified. The burgesses would settle that matter. 
At most of the English and Welsh baronial boroughs the burgages had no connection with particular acre-strips, the burgage paid one rent, each acre of land another; elsewhere, both in created and in ancient boroughs, the lands paid no rent as such. ${ }^{1}$ At Leeds and at Denbigh it seems probable that there was some connection between the burgage and the curtilage which went with each. Very likely the connection long remained. A burgess needed a garden; in many boroughs he had one near his house; it was sometimes called an orchard. At Denbigh there seems to have been no room for such within the walls, as the place was really a fort, and did not care to be wasted again. ${ }^{2}$ On the whole it is plain that there was no connection between the burgages and the acre-strips which lay dividedly in the common fields other than common tenancy of each by one holder. The greatest holder of messuages was not necessarily the greatest holder of lands; many a burgage holder had little land or none, and the landgable lay on the messuage within the ditch or wall.

How large as a rule was this messuage, this tenement of the towns? It has often been assumed that the mediaeval burgess lived in very narrow quarters, and to judge from mediaeval pictures and the width of old streets, he seems to have been somewhat large for his house. Picturesqueness rather than accuracy, however, was the strong point of the mediaeval artist, and though no doubt the assumption of limitation is correct in the main, it appears to be scarcely safe to judge wholly from this sort of evidence, and still unsafer to form an opinion of the character and size of the messuage of the middle ages from the small and ruinous burgages of the period immediately preceding the Reform Bill. Nor yet do the burgages of charter-created boroughs afford a criterion. Such boroughs were often artificial and the

From Giraldus Cambrensis to Macaulay every writer who touches on the Irish boroughs speaks of the condensation of the houses in the 'English towns.'

1 Cambridge, where land rents and house rents were separate (see p. 62), affords apparently the only exception among the ancient boroughs, at least in the age of records.

${ }^{2}$ Possibly Maurice Paganel, the charterer of Leeds in I208, may have been influenced by the peculiar fashion of the bastides. 
clauses in their charters which limit the frontage of a messuage to twenty feet or less or more, though wise in aim and probably good in result, refer only to a minimum within which a burgage must not shrink without endangering its holder's burghal status. ${ }^{1}$

In a few records of transfer the locations and sizes of the messuages, some of which were plainly residences and some as plainly shops or stalls in or near the market-place, seem to show that the town-dweller was not always cramped for room or forced to pay a very high rent. When three messuages in London which together had a breadth of 80 feet to 93 feet, each being I 50 feet deep, were rented for half a mark yearly, ${ }^{2}$ and another of 44 feet by 200 feet was sold for two bezants and a yearly rent of a shilling, ${ }^{3}$ real property seems to have been cheap and tenements large. When, however, a piece of land 34 feet by I $7 \frac{1}{3}$ feet, probably near St. Paul's, was sold for two marks of silver and a yearly rent of twenty shillings, size and value at once change places. ${ }^{4}$ The messuages of the first two transactions consisted apparently of houses with gardens at the back on land 'sloping toward the Thames'; the small plot seems to have been a business stand. ${ }^{5}$

1 In direct contrast to the boroughs of minimum limit was Dublin, where a lateadopted clause of the customal enacted that " each burgage within the city should not exceed 64 feet" (Gilbert, Records of Dublin, i, p. 224).

${ }^{2}$ C. A. D., i, p. 194, temp. John.

${ }^{3}$ C. A. D., i, p. 196, temp. Henry III. In this and the previous record the dimensions are given in ells, probably cloth ells. If land ells, $20 \%$ should be deducted from every measurement.

4H. M. C., Rep., 9, pt. 1, p. 67, a. 1132. The form of transfer is quite unlike the stereotyped uniformity of later deeds: "Facta est conventio haec inter canonicos beati Pauli et Meinbodum, videlicet quod concedunt ei terram quam prius tenuit, et juxta illam aliam quae in longitudine xxxiij pedes et in latitudine xvij pedes halet et dimidium. Concelunt inquam ei et heredibus suis in feodo et jure hereditario, cum socca et sacca, singulis annis pro $\mathrm{xx}$ solidos . . redelendis. Pro hac autem conventione dedit prefatis fratribus ij marcas argenti." Shortly before, the annual rent was only $2 \mathrm{~s}$.

- Dimensions of messuages from a few of the fair number of recorls of size are: London, 2 John, $60 \mathrm{ft}$. Jy $40 \mathrm{ft}$. (Placit Westmon. Abbr., p. 27, rot. 13, dorse); London, temp. Henry $111,130 \mathrm{it}$. by $28 \mathrm{ft}$., terms $\mathrm{x}$ bezant, i sextary of wine, $12 \mathrm{~d}$. rent. Nothing is said of houses in any of these grants; probably all the lots were built on, the measurements are given in ells.

"Assisa pro lxxiiii pedatis terre in longitudine \& sex pedatis terre \& dimidio in latitudine" in Petersfield; "pro tenemento in suburbio Wynton pro vi pedatis 
The varying sizes of messuages are apparent from the appended records, many of which may concern land alone regardless of the houses built thereon, to judge from size and price. These records of large, low-priced, London tenements seem to have something about them savoring of transfers for a merely nominal sum. Perhaps a truer idea of the worth of real property in London may be got from the fact that roomy substantial tenements for rent, most of them of the nature of modern three-flat apartment houses, though without janitors or elevators, might be obtained in the first part of the fourteenth century or earlier for $£_{\mathrm{I}}$ or $£_{2}$ a year. ${ }^{1}$

longitudine \& iii pollicibus latitudine" (Placit. Westmon. Abbr., p. I89, 4 Ed. I); these are oddities.

Dublin, I 262-6.3, 6o ft. by $7 \mathrm{ft}$. (Gilbert, Records of Dublin, i, p. 95, a line-fence dispute); London, $25^{\frac{1}{4}}$ ells by $8 \frac{1}{2}$ ells, rent 4 s. (C.A.D., i, p. 200); the land alone was granted, the houses thereon were worth 4 os. yearly; London, $21 \frac{1}{4}$ ells to 15 ells by $31 \frac{1}{2}$ ells, rent of assize (not the landgable) 3 s. a year (C.A.D., iv, p. 144); London, $28 \frac{1}{4}$ ells 6 in. by 4 ells and 7 in. (C. P. R., $a .1279$, p. 333 ); London, 1280 , "messuage of stone," 7 ells and 6 in. by $9 \frac{1}{2}$ ells and 8 in., "with all its court" of $6 \frac{3}{4}$ ells by 15 ells and 8 in. (C. C. R., ii, p. 245; the ell is the iron ell); Ipswich, temp. Ed. I, " a piece of land with buildings," $43 \mathrm{ft}$. by $23 \mathrm{ft}$., rent 2 s. 8 d. (C. A. D., ii, p. 227); Norwich, temp. Ed. II, two " placeae," $28 \mathrm{ft}$. by $9 \mathrm{ft}$. and $27 \mathrm{ft}$. by $10 \mathrm{ft}$., service $\mathrm{r} 6 \mathrm{~s}$. a year and four small rent-charges (Stanley v. Mayor, etc., ff. I 6 and 22; probably these are stalls in the market); Norwich, "messuage and garden," Io perches by 5 perches (C.P.R., a. 1380, p. 496); Carlisle, " tofts," $18 \mathrm{ft}$. by $33 \mathrm{ft}$. and $\mathrm{I} 8 \mathrm{ft}$. by $45 \mathrm{ft}$. (C. C. R., iii, p. 93, $a$. г3०7); Oxford, two messuages, together $90 \mathrm{ft}$. by $57 \frac{1}{2} \mathrm{ft}$. (C. P. R., a. 1380, p. 527 ); Liverpool, I314, $24 \mathrm{ft}$. by $65 \mathrm{ft}$, , four rents whose sum was $\mathrm{I} 8 \frac{1}{2} \mathrm{~d}$.; London, I9 Henry VI, two tenements each $28 \mathrm{ft}$. by $27 \mathrm{ft}$. of assize, ro ft. apart (H. M. C., Rep., 9, pt. I, p. I2). See also Benham, Red Parchment Book of Colchester, pp. 45 et seq., for sizes and rents of messuages in the fourteenth century.

${ }^{1}$ For a detailed and accurate description of London houses see Riley, Munimenta Gildhallae, i, pp. xxx-xxxi.

The constant use of the ell, in London especially, as a unit of measurement is confusing. The cloth ell was 45 in. between the lists, and this ell was statutory temp. John. The land ell was 36 in. but was not statutory till a period (? temp. Edward II) later than that of most of the subjoined records. The iron ell of many grants, so-called from iron standards at London and other cities, was the cloth ell. See Maitland, Domesday Book and Beyond, pp. 37r et seq., and also Statutes of the Realm, i, pp. 206-207.

There are many records showing how close to modern city conditions land or real estate holding in the mediaeval boroughs approached, the manner in which the tenement had been and might be divided, and the uniformity of building and holding all over England. Fitz-Alwyn's Assize in the thirteenth century shows the 


\section{Foreign Tenures within the Borough Bounds}

Every borough had its 'ancient metes and bounds,' 1 - far beyond the ditch or wall as a rule, and often impressed on the burgesses' memories by ' riding the bounds,' - within which it is commonly assumed that all real property was held under burgage tenure. ${ }^{2}$ Within some of the ancient boroughs, however, there were little islets of feudalism, tenements not under burgage tenure. Of this sort might be a few acre-strips in the fields, perchance in early times and rarely an isolated tenement in a borough; ${ }^{3}$ in neither case was the holder considered a bur-

character of the usual London house, and, except that the houses may not always have been so high, the same plan was followed in most of the older English boroughs. The common expression in reicring to a house was ' cellar, solar, and curtilage.' The cellar was nearly always a fairly high basement, the 'solarium' was the second story, the third story was the 'attic.' Each story or any part of it might be a burgage tenement. The curtilage was the yard, or yard and garden. See Frost, Hull, p. 46; Stevenson, Records of Nottingham, p. 388; H. M. C., Rep., 3, p. 360 (Wells) ; ibid., 11 , app., pt. 3, pp. 57 (Southampton), 63, 90; ibid., 15, app., pt. 10, p. 139 (Coventry); Parkin, Lynn, pp. 123, 133; Cole, Renlal of the llouses in Gloucester, p. 47 ; D. B., iv, Liber Winton', If. 3 and $4 \mathrm{~b}$; Gilbert, Records of Dublin, i, pp. 109-1 10 .

For the solar see C.A. D., iv, p. 223 (London), "sollar' "sine fundamento"; H. M. C., Rep., 3, p. 314 (Bridgwater); ibid., 5, p. 605 (Exeter). For curtilage see D. B., iv, Liber Winton', f. 7; H. M. C., Rep., 6, p. $48_{3}$ (Bridport); ibid., 1o, app., pt. 3, p. 28 I (Wells).

The shrinkage or decay of the original burgage, so prominent in the period before the Reform of $\mathrm{I}_{32} 2$ (see Edward l'orritt, The Lureformed IIouse of Commons (Cambridge, 1903), i, lp) $37-41$ ), seems to have begun before the close of the midlde ages. For records of such 'ruinous tenements' see H. M. C.. Rep., 6, D. 520 (Ilythe); Cole, Rental of the Houses in Gloucester, p. 5; Widdrington. Analecta Eboracensia, 1. 255; C. I. M., Jenry VII, i, pp. 100 (Richmond); ibid., i, p. 1.46 , R. F., knight, held 24 messuages in York worth 20 d. each " and no more, being in ruins for lack of repairs"; ibid., i, p. 28r (Exeter); Madox, Firma Burgi, p. 118 (London).

1 Created boroughs, of course, excepted.

2 This is generally the situation, as a charter to bullin (Walsh, Dublin, i, p. 37S) shows. In bublin and the other amcient boroughs the tenure had grown up on certain lauls. Wublin wats a Danish city when the English got it, and the Bristol customs, for instance the low and variable landgable and free devise, seem to have fitted it so wedl that they were probably not very difierent from its own.

3 David the Dser's tenement in Carlisle, so frequently referred to by town historians, is apparently the only example of the latter sort. See Thomas Madox, The History and Intiquities of the Exchequer (2d ed., 1769), i, p. 404, and Baines, Literpool, p. 92; the latter use's this example to prove that no one had 'burgage' 
gess. ${ }^{1}$ During the middle ages the boundaries of a few small boroughs were extended, usually by piecemeal additions, ${ }^{2}$ and a few of the greater boroughs were enlarged by the addition of villages near by, ${ }^{3}$ but in general a borough's tenurial boundaries remained the same all through the mediaeval period.

Far greater in number and in importance than these ostracized foreign holdings were the messuages in the fee of the castle, which in many boroughs rose almost in the midst of the town, from whose houses nothing separated it but its ditch. The castle itself was, of course, under feudal tenure, and as it often

rights unless he lived on 'crown land' meaning probably that a burgess must hold directly of the king in a royal borough. This was never the case; even in charter created boroughs burgess rights went with every tenement till it fell below a minimum frontage; even then it was still held in free burgage. The burgages of the 'burgage boroughs' of the ante-Reform Bill period were, however, held of the lord of the borough and paid landgable.

1 Probably the pieces of land in the fields were or had been parts of manors. They may have been more frequent on the Welsh border. See Johnson, Customs of Hereford, pp. 36-37, a. 1280-81: "There are some lords and their tenants who are dwellers and holders of land within the said bounds which they held by a service called Liberum Feodum. . . . But concerning their foreign service . . . their lords are not excluded by us nor by our liberties. For we never intermix ourselves with them in anything touching those tenures. . . Such men . . . are not burgesses." Widdrington (Analecta Eboracensia, pp. 249 ff.) has a long story concerning a messuage in York held in grand serjeanty by the service of keeping the jail of the forest of Galtres.

${ }^{2}$ At Plympton the Earl of Devon, when granting the borough at farm to the burgesses for $£_{24}$ 2s. 2 d. in $\mathrm{I}_{242}$, saves " to the earl any increase he can make in rents of ... foreign lands without the borough" (C. C. R., ii, p. 3०3).

The prior and convent of Montacute granted an extension of the borough along apparently the only street (Somerset Record Society, [Publications], viii, Bruton and Míntacute Cartularies, p. 2 Io; the place seems a strung-out western village, very different from the nucleated eastern type). See also Head, Congleton, p. 34.

${ }^{3}$ C. C. R., ii, p. 474, a. I 298 (Newcastle); ibid., iii, p. I9o, 40 Henry III (Scarborough).

Political and tenurial boundaries were not always co-incident. See Mrs. J. R. Green, Town Life in the Fifteenth Century, ii, p. 40 for Carlisle and Hereford. At Lymington in the nineteenth century the borough boundaries were undefined, tenements not burgages stood "within the heart of it "; and some of its burgages were separated from the borough. Tradition has it that, the French having burned most of the town during the Hundred Years' War, every newly-built house not standing on an ancient site was held to be "exclusive of the borough," a resolution illustrative of the exclusive and intolerant spirit of the fifteenth century burgesses. See Parliamentary Papers, 1835 , xxiv, p. 743. 
had its own dependent lands on which houses stood, one would expect to find these held under the same tenure as the castle. Urban influence and previous tenurial conditions, however, were too strong for feudalism; in such cases the tenements of the castle-fee were held in burgage tenure. The governmental and political relations of such tenements and their holders are other matters; the character of the tenure is clear. ${ }^{1}$ The sheriff or the castellan collected the rent of the castle messuages, and the town had no share in it. At Norwich the lands in the fee of the castle were granted to the citizens in $1344-45 ;^{2}$ the castle itself was still a part of the county in the eighteenth century. ${ }^{3}$

In every borough there were areas, bits of no man's land, odd corners, and above all the streets, held directly by no person and called the 'waste.' To whom did the waste belong, to the commonalty or the lord of the borough? 'Today streets and public places are civic property; in the middle ages they were

1 See Cooper, Cambridge, i, pp. $58,92, a .1278$ and 1340; a gift of the castle specifically excluded escheats of its tenements.

In 13 so an inquisition ad quod damnum stated that all the tenants of a messuage in Norwich, in the fee of the castle of Norwich had "alienated, . . . bequeathed, and assigned " it from a period to which the jurors' memories ran not to the contrary, " as citizens elsewhere in the city aforesaid do with their tenements," without the license of the sheriff "or other ministers of the lord the king" (Stanley" $v$ Mayor, etc., f. 24).

At Liverpool c. 1355 the Duke of Lancaster granted a messuage to a burgess which messuage the "late constable of our castle of Lyverpull held of the gift of Lord Henry, late earl of Iancaster." The services were the same "as the other tenants of the same town do for like messuages." As at Norwich the town bailiffs did not collect the rents (Baines, Liverpool, p) 154).

At London the juratores "dicunt quod Turris Londoniae cum Judaismo et aliis pertinentibus est de dominico domini regis et est in manu sua " (K. II., i, p. 4 IS). (irants of such 'pertinentes' show the tenure to have been free burgage and the rents commonly id. each.

At Oswentry in 1406 the burgesses were " lischarged from all fees demanded by the Constable of the castle," but the constable got, at his election, id. from every 'mansion house, or original burgage, in the town (Cathrall, Osauestry, p. 47). Oswestry wats once a garrison borough. See also (: I. M., ibid., Itenry VII, i,

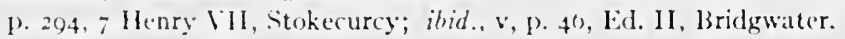

" lludson and Tingey, Records of Foricich, i, p. xliii.

${ }^{3}$ Blomefield, . Torfolk, iv, p. I 22. 
the borough lord's. Unless he had granted the waste ${ }^{1}$ to the burgesses no one might lawfully 'approve' it without his permission. ${ }^{2}$ Grants of the waste during the earlier part of our period were commonly grants of small plots to individuals. ${ }^{3}$ It may have been that this approval of the waste at low rates by the king led the Norwich burgesses to ask in 1307 that it be granted to them, but their hour had not yet come. Even the land beneath the streets was the lord's. The friars of Oxford had to get leave to tunnel thereunder. ${ }^{4}$ In some boroughs the waste was given to the burgesses in its entirety, at an ' early period' in London, ${ }^{5}$ in the twelfth century at Bristol; ${ }^{6}$ often, however, the boroughs got the waste because they took it, ${ }^{7}$ a silent process usually whose only records were those of attempts

1 Where a borough had pasture land in addition to the arable it was commonly communal property and was called not waste but pasture.

2 See Scott, Berwick, p. 247 , a. 1307, "waste-places within the palisades"; ibid., p. 250, a. I333-34; H. M. C., Rep., 5, p. 515, 33 Henry VI, Rye, vacant land belonging to the king; Matthews, Cardiff Records, i, p. 176, a. 1492, the bailiffs account for "three parcels of waste land lying within the liberties."

${ }^{3}$ C. P. R., a. 1300, p. 5 I I, " a void plot . . . in Bedeford, shaped like a shield," $152 \mathrm{ft}$. long, $2 \frac{1}{2} \mathrm{ft}$. wide at one end, $92 \mathrm{ft}$. at the other; the terms were $6 \mathrm{~s}$. $8 \mathrm{~d}$. down and Is. a year perpetual rent, "payable at the Exchequer by the hands of the sheriff "; see also ibid., p. 536, Ravensrod.

Stanley v. Mayor, etc., of Norwich, f. 2I, a. r304; the king allowed William de Colton to enclose and build on two places; the rent of each was $\frac{1}{2} \mathrm{~d}$., due the king, payable to the bailiffs, and called landgable; cf. Bedford. See also C. P.R., a. $\mathrm{I} 302$, p. 50 , for similar cases.

${ }^{4}$ C. P. R., a. I318, p. 168.

5 Calthrop, Usages and Customes of London, p. 25.

6 Seyer, Bristol Charters, p. Io (II88). Scarborough got the waste in I 253 (C. C. R., i, p. 4I 7); Scarborough claimed to be a borough temp. Henry I (Baker, Scarborough, p. 28 ); Berwick in 1307 (Scott, Berwick, i, p. 247); Norwich in 1329 (Blomefield, Norfolk, iii, p. 8o); Southampton in 27 Henry IV, and so on.

7 Sometimes the burgesses had the grace to petition for a grant of the waste. At Norwich in 1307 the burgesses asked in vain. No whit discouraged the community proceeded to act as if the waste were its own and in 1329 was in conflict with the king's escheator south of Trent, houses having been built on the waste "by grant of the city." Edward II's reign afforded an excellent opportunity for such unlawful 'approvals' of the waste; their extent can be seen from their rents, which in 1307 were $9 \mathrm{~s}$. $2 \mathrm{~d}$. and in 1329 were $£_{9}$ IIs. $8 \mathrm{~d}$. The dispute was ended by the king's granting the waste to the citizens (see Blomefield, Norfolk, iii, p. 8o). 
to check it, ${ }^{1}$ attempts which often resulted in further extension of the tenure and exclusion of the borough lord.

1 See Atcheson, Case of the Borough of Petersficld, a. 1613. Among other usurpations the burgesses had approved the waste without leave. The justices refused to decide the ownership of houses on the waste, advising the borough lord to proceed at common law (p. 16). The modern legal view was apparently taking the place of the old. At Sandwich the waste seems to have been considered communal property. The mayor and commonalty "possunt eciam et solent edificare, si voluerint, areas vacuas" (see Boys, Sandwich, p. 534). See Maitland's views and comments concerning the waste in Cambridge in his Tounship and Borough, pp. $187-189$. Few borough courts leet were held in the later part of our period without some one being presented for 'purpresture,' $i . \varepsilon$., unlawful approval of the waste, the most common form being encroachment. 


\section{CHAPTER III}

\section{MOBILITY}

"THE mercantile spirit of the boroughs affects the houses . . a and it is in the boroughs that landownership first reaches a modern degree of purity and intensity." 1

So far in this discussion of the tenure the mobility of the burgage tenement, that is the burgess's power to alienate or divide his messuage, has been presupposed but not defined. We shall now try to deal with this subject in detail; to show where and to what extent a burgage tenement might be divided, sold, or devised; whether such liberty existed in all the boroughs, and if so under what (if any) conditions; that is, where and whether the mobility of the messuage lay under complete or partial restriction, or under no restriction at all. The general line of treatment, therefore, will be freedom of division; of alienation, or buying and selling; and most important or at least most significant of all, freedom of devise.

It may be suggested that liberty to divide means liberty to sell. One might divide and still not sell, in appearance at least. The early records of division are mostly of this sort; the grantor ' enfeoffs,' just as outside of the boroughs, ${ }^{2}$ though in substance the grant is in no way feudal. The prevalent view seems to be that there was no restriction on the mobility of the burgage tenement. So Bracton virtually states, and viewing the boroughs in a mass and from a distance the idea is in the main correct, for most of the older boroughs at least. An individual view of the boroughs from near at hand will, however, disclose many exceptions to and divergences from any general rule of mobility, especially in respect to freedom of devise.

1 Maitland, Township and Borough, pp. 7 r-72.

2 He still enfeoffs for that matter. 


\section{Divisibility of Burghal Realty}

The attitude of the feudal land law toward division of a fief ${ }^{1}$ is too well known to need description. Exactly opposite is the attitude of the land law in the older boroughs, where there seems to have been no limit whatever on extent or manner of division, not merely of land but of houses. In the ancient boroughs the evidence for division comes mostly from grants. The customals do not concern themselves with a matter of common right and universal knowledge. ${ }^{2}$ The length to which division might be carried is seen in a grant of a sixth of a sixteenth of a tenement in London, ${ }^{3}$ and one forty-eighth of a burgage in Liverpool. ${ }^{4}$

As with many other customs, divisibility in the chartered and created boroughs appears to have a tinge of artificiality about it. In the older towns burgesses night divide as fancy led them; in created boroughs it seems often to have been taken for granted that he who divided a messuage would do so evenly. The charters to such boroughs contained permission to divide the burgages and conferred the same privileges on him who had half a burgage as on him who had held it all. ${ }^{5}$ It has been suggested

1 Except among co-heiresses.

2 Agrant of a 'moiety of land' in Gloucester, c. 1200 (Steverson, Records of Gloucester, p. 8.4). At Bridgwater in 1245 a grant of " half a messuage" conseyed "the whole of the solarium with half of the bedchamber and of the curtilige" (II. M. (.., Rep., 3, P. 3II). It seems that the grantor retained the collar and half the yard. The two tenants shared the attic. For extensive division see also I'arkin, L.1nn, J. 123; R. II., ii, J) 357 , and Maitland's comments in his Tou'nship and Borough; Bateson, Records of Leticester, i, p. 300, a. I 201-02, releatse of a third of a messtage; Ifudson and lingey, Records of Norwilh, i, P. 253, a. 1202-95, "medictatem . . mesuagii"; H. .1. (.., Kep., 3. 1). 57 and Kep., 5, Pp. 500, 601 for Southampton, Dartmouth, and Rye, where "a room in a tenement " was granted. Weare, Thornbury, and kichmond show grants of halves, thirds, and

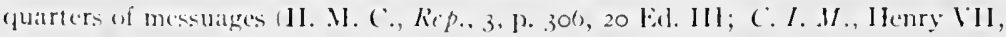
i, p. 100, I Ilenry VII).

${ }^{3}$ ( $:$. . .1. IJenry VII, i, pl). 2.41 and 382 . The property scems to have been a wharf or a warehousc and wharf. It is called . le ()lel Wol Key'; in another

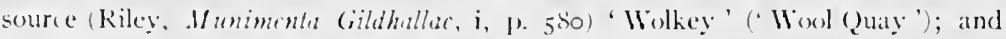
the sixteenth is probably one share held in portions.

- I'ictom, Liverpol Records. i, 1). 12, a. 1346).

s Bennett, Thakestury, [). 321 (a. 1147-8,3). Holders of hali-burgages were to 
by an eminent scholar ${ }^{1}$ that " there was no doubt a limit to this process" of division, as a twelve-foot burgage was necessary at Preston to give its holder burgess rights. ${ }^{2}$ This limit, however, concerned frontage only, which division might not affect at all; the threatened loss of burgess rights would have an effect in proportion to their value. The Cardiff charter gave burgess rights to those who held half-burgages, ${ }^{3}$ which were probably halves of original messuages, a simpler and more effective method than a limitation of frontage for restricting burgess rights to the responsible citizens. ${ }^{4}$

As tenements might be divided, so their parts, or new tenements, as we may regard them, might be reunited, as at Scarborough ${ }^{5}$ and at Cambridge. ${ }^{6}$ At the latter town it is apparent that the various parts (or messuages) when joined, formed but one messuage; unlike the custom at Scarborough but probably in accordance with the usage elsewhere, the hawgable of the new messuage seems to have been the sum of the hawgables of its various parts. This was the reverse process of divisibility; its complement was holding in coparcenery, for when a burgage descended to co-heirs it must be so held or else divided. Coparcenery was a recognized though not a common form of holding under burgage tenure; entered into involuntarily, the fluidity of urban realty rendered its avoidance even easier than in the

have the same rights as holders of whole burgages. Cardiff has the same provision in its charter; the Earl of Gloucester was lord of each borough.

Tait, Mediaeval .1Lanchester, p. 66, a. I301: "quilibet potest vendere . . . sive maius, sive minus, sive totum "; in the fifteenth century there were many halfburgages there (ibid., p. 68).

Wardell, Leeds, app., p. iv: "Whoever shall purchase any part of any such toft . . . is as free as if he have purchased the whole toft "; H. M. C., Rep., 8, p. 269, 5 Rich. I, Pontefract: "Quicumque emerit aliquam partem alicujus tofti," etc.

1 Professor Tait, in his .Mediaeval Manchester, p. 68.

2 The usual formula was 'may make free burgesses (or free tenants) by $20 \mathrm{ft}$. frontage,' as at Inistiogue, $40 \mathrm{ft}$., as at Kilkenny, etc.

3 Matthews, Cardiff Records, i, p. I 2.

4 There was, however, a large amount of more minute division in Cardiff.

- Brown, Forkshire Inquisitions, i, p. 21, a. I250; the previously quoted case in respect to the action against the abbot of Citeaux. See p. 7 I , note 2.

${ }^{6}$ R. H., ii, p. 357: " unum messuagium in . . Cantabrigia . . quod messuagium idem $T$. de diversibus hominibus emit per particulas, unam scilicet partem de R. . . . et aliam partem de A.," 4d. hawgable. 
country. At Ipswich in I 254-95 the borough court decided that when a burgess left daughters only, "his lands and tenements shall dessend by the Custome to them in coparcenery," 1 but the scanty evidence for the existence of this form of holding comes from records of transfer rather than customals. ${ }^{2}$ Joint tenancy and tenancy in common seem commoner than holding in coparcenery. These were dissoluble only by mutual consent. ${ }^{3}$

From what has gone before it may seem as if there were no restriction whatever on divisibility other than forfeiture in some boroughs of burgess rights by one whose tenement fell below the minimum frontage. Complete freedom to divide one's messuage, however, existed only in the boroughs where realty might be alienated without impediment among the living,' and for only one generation in nearly all the created boroughs. Even in these the 'divide' of the charters seems to mean divide once and no more. In the second and subsequent generations division was limited to purchased tenements, though probably in a few of these boroughs inherited tenements might be divided among the heirs themselves or among others with the heirs' consent. ${ }^{5}$

\section{Free SAle}

This limitation on divisibility in certain boroughs brings us to a distinction in the nature of the lands at many places, a

1 Bacon, Annalls of Ipsaciche, p. 8. Such tenants must essoin together (ibid., p. 10).

${ }^{2}$ It Southampton, for instance, temp. Ed. I is a conveyance of a "petrinum [i.e., solarium] cum uno cellario " by two brothers and three of their sisters, judging from the names, to a fourth sister and her husband (II. M. C., Rep., r1, app., pt. 3 , p. $5^{(1)}$; the family appears to have held the messuage as a unit. For the custom of descent of realty see Gross, "Intestacy in Mediacval Boroughs" (Antiquary, 1885).

". It IV'inchester, $1103^{-15}$. we find "i domus modo manent ibidem iii homines" (D. B., ir, Liber Winton', f. 2), and another domus held by father and son (ibid., f. 8). It Maldon a record speaks of a tenement in two men's hands (C. P. R., a. 1.401-05, p. 308), and at colchester another concerns two tenements held conjointly by five men (Benham, Red Paper Book of Colchester, p. og). For coparcenery in the country. see Statutes of the Realm, i, p. 77 .

4 See below, Free Sale (p. 110), and Restricted Sale (p. 11.4).

5 Hence, though not exclusively, the halves and quarters of messuages so frequently met with. 'Thirds of burgages probably arose out of dower. Fractional or any sort of division depended largely on any particular borough's rule for descent of realty. 
distinction which was not confined to the charter-created towns but which affected many of the older boroughs of England throughout the middle ages. It was based on the manner in which tenements were acquired, 'lands of inheritance' or ' lands of purchase,' the significance of which division lay, as far as sale was concerned, in its connection with the kin's preemption or retrait lignager. Wherever the kin's preëmption existed sale was limited ${ }^{1}$ to lands of purchase, elsewhere it was free.

The evidence as to buying and selling messuages or parts thereof comes mainly from three kinds of sources: grants and releases of tenements; charters and customals; and inquestfindings in the course of legal processes, especially those cases taken to the royal courts by writ of error in judgment. ${ }^{2}$ Statement in a charter or a customal that sale was free is conclusive and final evidence, for though customals might be changed and charters amended such change and amendment as touched the tenure were nearly always toward freedom and never the reverse. The evidence drawn from grants and releases is not so satisfactory, for in many boroughs some of the messuages might be sold freely and some might not. The evidence of a large number of grants in the same borough, even though none should contain any mention of restriction on sale, does not necessarily prove that sale therein was free; they may all relate

1 The amount of limitation depended on location and period.

2 Appeals from the decisions of a borough court might be heard before a royal justice in his court (oyer and terminer) in the borough or be argued before the bench at Westminster. The reports in the Year Books and the Placitorum Westmon. Abbreviatio show that the justices usually accepted without question the law as declared by a jury of burgesses.

Appeals from a decision of the Hustings in London were heard by a bench composed of the mayor, or mayor and sheriffs, with whom were associated certain assessors named in the commission. They sat as a court of oyer and terminer. See C. P. R., a. 1282, pp. 46, 47 et pass.; also R. R. Sharpe, Court of Husting, introd., p. iii; for the Hustings as a court of record see Riley, Munimenta Gildhallae, iii, pp. I6, I 7 .

For the 'gavelet,' from which the holder could not be ejected for a year and a day for default in rent, and which the demandant might then hold for the following year and day, see ibid., iii, p. 22; C.A.D., i, p. 200. For the Statute of Merchants of Acton Burnell, see Statutes of the Realm, i, p. $16_{5}$. 
to lands of purchase. Unless such records contain internal evidence that they concern lands of inheritance they prove nothing one way or the other in respect to freedom of sale.

From this sort of evidence, as found in conveyances of realty, it seems probable that sale was free at Leeds ${ }^{1}$ and Pontefract; ${ }^{2}$ there is little doubt that it was free at Gloucester ${ }^{3}$ and Leicester. ${ }^{4}$ At Winchester ${ }^{5}$ in the later part of the thirteenth century sale was unrestricted, though it seems that such freedom was of very recent lawfulness. ${ }^{6}$ At Lynn ${ }^{7}$ and probably at Bridport ${ }^{8}$ the impediment of the kin's preëmption was absent. It is scarcely necessary to add that sale was free in such places as London, Bristol, and Oxford, not alone because they were the more important boroughs, but because their abundant and wellknown records prove it. ${ }^{9}$

I See Wardell, Municipal II istory of Leeds, app., p. ir. Any burgess may sell his land to whom he will. It is a question whether he might so act with inheritance.

${ }^{2}$ H. M. C., Rep., 8, p. 269, 5 Rich. I. The charter draws no line between purchase and inheritance. Pontefract, however, had the Grimsby customs.

${ }^{3}$ H. N. C., Rep., I 2, app., pt. 9, p. 409: A. " emit [terram] de Balclwino filio sacerdotis: tenendam in .. . hereditate." Filius sacerdotis, filius nulliws, however. Stevenson, Records of the Corporation of Gloucester, Pp. 138-150, c. I230, shows no restriction on sale, with one possible exception, for which see p. 12 I, n. 2 .

4 Thompson, Leicester, p. 69, a. 1254; a rent " by hereditary right" was sold.

${ }^{5}$ C. I. M., i, p. $283,5^{6}$ IHenry III: a "messuage . . . is not the king's escheat .. . for the king gave it to . . . G. and his heirs, and he had a son . . who . . . sold it." In other words a tenement of inheritance was sold.

${ }^{6}$ The kin's retrat seems to have been legal early in the thirteenth century.

7 P'arkin, Lynn, PP. I 23, 173, 205 (a. 1273).

${ }^{8}$ H. M. C., Rep., 6, p. 4 80, temp. Eal. I. An heir granted " lands, tenements, and mills " formerly belonging to his father and therefore the son's inheritance.

9 See, for Bristol, Bickley, Litlle Red Book of Bristol. Wadley, Circal Orphan Book, etc.; for Oxford, Rogers, Oxford City Documents, $12688^{3}-166_{5}$.

It may be that the kin's preemption existed in every borough ats latte as the twdith century. Miss Bateson (Borough ('ustoms, ii, p. 61), quoting from Felix

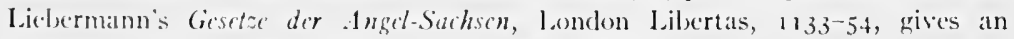
instance of the kin's retrat in london at that period.

Bracton (I) Le Leg., is, pp. 202 f.) tells us that "item [mort dancestor] caldit . . propter eonsuetulinem loci, ut in . . burgis . . et tenementis quac sunt de perquisite, sicut in . . . civitate London et alibi." Mort d'ancestor 'fell " for tenements of inheritance $t w$ in many boroughs, yet Bracton says nothing of such. Indeed he stumbles more than once in his comments on the customary law of the boroughs (see p. 130, note 2). Retrait lignager had disapueared in London long before Braten's day; there is no trace of it in the $I$ 'sages and Customes (Calthrop), Liber (irstumarum (Riley), or Court of IIusting (Sharpe). 
Dublin followed Bristol as a borough of unrestricted sale, and Limerick, Waterford, ${ }^{1}$ Cork, and Rathcool followed Dublin. The charters to the baronial boroughs of Congleton ${ }^{2}$ and Castle Rising, ${ }^{3}$ the episcopal borough of Chard,${ }^{4}$ and the royal borough of Hull ${ }^{5}$ allowed free sale for all tenements. At Wycombe, ${ }^{6}$ Altringham, ${ }^{7}$ and Rhuddlan ${ }^{8}$ freedom of sale was without limitation or was directly stated to be allowed in respect to an heredity. Some of these illustrations are from the charters of boroughs in which there was often a prohibition of alienation in mortmain. ${ }^{9}$ In the older and larger boroughs sale was regulated not by charter, but by custom, which the burgesses could change. ${ }^{10}$ It was just as well for them not to have certain provisions of their land law incorporated in any charter, otherwise change might be difficult. In I $200 \mathrm{King}$ John gave a charter to each of the two very similar boroughs, Nottingham and Northampton, ${ }^{11}$ whose land laws were probably identical. In

1 "That all fermes did enswe the nature of fee simple landes within the citie" (H. M. C., Rep., ro, app., pt. 5, p. 333) probably refers to the fact that the distinction between purchase and inheritance did not obtain.

${ }^{2}$ Head, Congleton, p. 34, a. I272: the charter was from Henry de Lacy.

3 Parkin, Lynn, p. 205: from the Earl of Sussex's charter of ante 27 Henry III.

${ }^{4} C$. P. R., $a$. I 286, p. 216 : the charter, confirming that of his predecessor, was given by the bishop of Bath and Wells in $\mathrm{r} 280$.

${ }^{5}$ Sheahan, Hull, p. 50, $a$. I 299: Hull (Kingston-upon-Hull) was almost the only borough of royal foundation. Orerton was made a liber burgus by the king in I29I. The bastides of Guienne may have suggested his gift of wood from his forests to build the houses. See Madox, Firma Burgi, p. 39 .

${ }^{6}$ Plac. Westmon. Abbr., p. I88, 3 Ed. I: "Et juratores requisiti si consuetudo sit in villa de Wycumb quod aliquis de etate xiii annorum possit terram suam dare vendere ... dicunt quod quam cito habeat plus quam xii annos potest secundum consuetudinem ville terram dare, vendere ..."

7 Parliamentary Papers, 1835, xxvi, p. 2574, c. I 290: "quod singulus burgensis burgagium suum possit vendere, invadiare, dare ... cuicunque vel quibuscunque voluerit."

${ }^{8}$ Ibid., I 835 , xxvi, p. 2838 : "unus puer masculus vel foemina potest vendere hereditatem suam cum pervenerit ad etatem xiiii annorum."

9 See Gross, "Mortmain in Mediaeval Boroughs" (A merican Historical Review, July, 1907). Alienation to Jews, king's officials, and infrequently to chief lords, was forbidden in some towns. Lands were usually given, not sold, to the church; one could trust the religiosi for that.

Io See Stubbs, Select Charters, pp. I Io-i I I.

11 Ibid., pp. 308-3I I. 
the former the charter fixed a restriction on sale, which, of course, could not be legally removed without the king's permission; in the latter the matter was left, as in most of the ancient boroughs, to the burghal land law. ${ }^{1}$

\section{Restricted Sale}

For this part of our subject the sources are mainly the borough customals, with occasional grants of real property and records of courts, where the grant may specify which sort of tenement was the subject of a sale, or the court record may contain a dispute in respect to an alienation followed by a decision of its legality or the reverse. This order of naming the sources will be in general the order of treatment, though chronological sequence is of little moment in regard to customals, unless there should be more than one for a single borough or evidence that there has been a change.

Sale was restricted by the letter of the law to lands of purchase at Cardiff ${ }^{2}$ and Tewkesbury, ${ }^{3}$ whose charters from the Earl of Gloucester embodied apparently the same customs. Preston ${ }^{4}$ and Pembroke ${ }^{5}$ had the same restriction, though probably lands of inheritance also might be sold with the heir's consent. Restrictions on sale were almost universal at created baronial boroughs on or near the Welsh marches, though by no means limited to that locality. ${ }^{6}$ There were exceptions, however, as at Hereford, a royal borough, where one might sell lands

1 Hardy, Rotuli Chartarum, p. 45: "et de terris suis et tenuris quate infra burgum sunt rectum eis teneatur secundum consuetudinem burgi."

2 Matthews, Cardiff Records, i, p. 12: "each burgess may at his will . . . sell or in any other manner alien his burgage which is of his purchase, to whomsoever he will. . . And if that burgage shall have been of inheritance, his own heir or heirs shall have it "; charter ante 1147.

${ }^{3}$ Bennett, Teitesbury, p. $32 \mathrm{r}$.

4 IJarlwick, Preston, p) 260; Fishwick, Preston, p. I6: "when a burgess shall be desirous to sell his burgage, his next of kin is to buy that burgage before any other" $(c .1 \mathrm{7} 73)$.

${ }^{5}$ C. P. K., a. 1378 , p. 107, " si quis burgensium . . . anno uno et dic domum vel terram sine calumpnia tenuerit ..."

"Wearmouth for instance had the same custom (Bateson, Borough Customs, ii, p. 01): "burgensi licet . . vendere . . terram suam . . sine concessu heredis sui quan ipse de proprio catallo suo emerit." 
of purchase or of inheritance "when and to whomsoever" he pleased. ${ }^{1}$ Though sale of inheritance was definitely forbidden under ordinary conditions and without the heir's consent at Cardiff and Tewkesbury, a subsequent clause of the charter (or customal) allowed its alienation in necessity. In both towns this took the form of the would-be seller's publicly asking his next kin to 'find him necessaries' ; these not forthcoming the tenement might be sold. ${ }^{2}$ Though there is no mention of such a limit of time at the two boroughs in question, in the older boroughs a year and a day's undisturbed possession of an inherited tenement gave the buyer security against ejectment by the next of kin.

The Northampton customal is very detailed in respect to the kin's preëmption and may be used to illustrate this feature of the old Germanic land law as developed by the mediaeval English burgesses. At that borough he who bought a tenement and held it unchallenged (sine calumpnia) by the seller's kindred for a year and a day was thereafter secure in his purchase if the sale were otherwise regular. ${ }^{3}$ At Northampton and elsewhere the heir was given every chance to exercise his retrait; if he were under age, or beyond the four seas, or in jail, the year and day did not begin to run until he came of age, or returned from abroad, or was enlarged. Northampton was unlike nearly all other boroughs of restriction in that there were occasions when no distinction was drawn between lands of purchase and lands of inheritance, the kin's retrait applying to both except when the seller held tenements of each sort. He who held messuages of either sort must, when he needed to sell them, offer the tenements first to the next of $\mathrm{kin},{ }^{4}$ and the time during

1 Johnson, Customs of Hereford, p. 25.

2 Matthews, Cardiff Records, i, p. Iog; Bennett, Tewkesbury, p. 32I. If a burgess "through distress of circumstances" was "obliged to sell or mortgage his burgage," he ought "for a first, a second or third time, to ask his heir to find him necessaries."

${ }^{3}$ Markham, Liber Custumarum, p. I7: "If any man resonably after the usages and the lawes of the town of Norhampton and bi wittnesse of the courte."

4 Ibid., p. 18: "If any man have any londes tenementes or rentes of his heritage or of purchase and he that londe tenemente or rente nedith to sellyn his kyne allwey 
which the heir had the option of buying was apparently four weeks, depending on the frequency of sittings of the borough court. If such a tenement had been sold before being offered to him the grantor's heir might come to court within the first four pleas, tender the buyer what he had paid and take the messuage but he must make the payment within eight days. If the sale should have been made out of court, that is clandestinely, there was no limit to the period during which the heir's option ran. To prevent fraud on an heir both buyer and seller must swear that the sale is bona fide and that the price offered will be really paid. ${ }^{1}$

If a burgess should hold tenements of both sorts he might sell those which he had bought without hindrance, and to whom he would. ${ }^{2}$ Under stress of poverty it seems that any sort of messuage might be sold. The clause of the customal which deals therewith is not remarkably lucid, but it is plain that an heir must either find the holder ' necessaries' or see the tenement sold. If sold, the heir had the option of buying it at the price a stranger would give, and the limit for payment was eight days, as in the case of forced sale. ${ }^{3}$ Under two conditions the kin's retrait was inoperative at Northampton: a burgess might give a part of his tenement, of whichever sort it might be, to his daughter 'in free marriage,' ${ }^{4}$ or he and his wife might sell

shall be moste nexte to aske the kate" (purchase). 'The "nedith' may' refer to 'sale in necessity'; a later clatuse, however, provided for that with its conditions.

I Markham, Liber Custumarum, p. I8: the heir may recover as soon as the sale is "shewed."

Is the proceedings at Cardiff and Tewkesbury were, no doubt, in the borough court the 'three summons' thereat may be compared with the 'four pleas' at Northampton, three weeks and four weeks respectively in all probability, though Cardiff, not being a commercial borough, may have held its court at the common intervals of three weeks.

2 Ibid., p. 24: "though his heire wolde hym withsayne." Usually "purchase' gets no such respectful mention.

3 Ibid., p. 19. li one "forpoverte or with owte poverte" wishes to sell his land, "his sone his doughter kymne the chefe lorde" shall not prevent it. "And if any man wylle his londe tenement, or rente taken or geven to fynde hym his sustinaunce terme of his lyfe he that is of his blode shalbe most nexte than astraunge man so he well done and fynden in the same maner as a straunge man wolle done."

- Ibid., p. 25. 
the realty which the latter brought at their marriage, whether it had been of inheritance or purchase. ${ }^{1}$ Rents were always subject to the same distinction and restriction as lands and tenements, and the heir who 'withsaid' (gainsaid) must be ' most next' of kin.'

Northampton had all the restrictions of other boroughs, and in addition a few of its own. Elsewhere in practically all of the older restricted boroughs, Portsmouth excepted, no obstacle lay in the way of selling purchase. To sell inheritance was forbidden at Bury Saint Edmunds in Abbot Sampson's charter of $1190,{ }^{3}$ and in the charter extorted from the monks in 1327 ; the latter dealt with the matter in greater detail. ${ }^{4}$ Sale was restricted at Portsmouth; ${ }^{5}$ Dover had the same custom and in addition was apparently the only borough of restriction where a penalty was provided by the customal for evasion or defiance

1 Markham, Liber Custumarum, p. I9.

2 That part of the customal which concerns the tenure is sometimes haphazard and tangled and in the present case at least has required much labor to interpret it. The clauses with reference to sale in ' need' and in 'poverty' are especially muddled. Either the burgesses were in the same state or the clauses are not contemporaneous. Was the heir's consent necessary to sale of purchase only when its holder was obliged to sell and not when he sold it voluntarily? In most other cases, whether the borough customs were compiled in Latin (as they commonly were), in French of a fearful sort, or in English, they are clear enough; whatever the language of writing, it is apparent that the language of thought was English.

${ }^{3}$ Dugdale, Monasticon, iii, p. 154 .

4 See Arnold, Memorials of St. Edmund's Abbey, iii, pp. 309, 3 I I. The next of kin to him "who shall sell his land or tenement . . . may have the buying of the tenements by his claim, which he shall bring before the next Portmannemote after the sale "; he must pay "to him who shall have bought it as much as he paid," and the usual precautions to prevent fraud on the next of kin are to be taken. One who has held "lands or tenements of his inheritance, or by purchase" for a year and a day without challenge shall remain in undisturbed possession.

The charter of 1190 was the same in brief, stated that the customs it granted to the burgesses "se habuisse tempore regis Edwardi," and allowed sale " necessitate cogente" the kin to have first offer.

5 East, Portsmouth, pp. 4, 5 (customal): [he] "that hathe Lond or Howse by purches or by dissente whereof he had seysing . . . a yere, and a daye withoutyn any Impechement or claym . . . to reioyse it for ev'more; but if " (i.e., except) "it so be that ther be any Wythyn age other" (i.e., either) "oute of the Lond or yn preson, that is to Wetyng" (i.e., to wit) "Brother, or suster, or Unkle, or Nevewe, or Nees." Temp. I4 cent. Both purchase and inheritance seem. subject to retrait. 
of the kin's right to preëmption.' At Romney, if an heir's tenements had been sold when he was in ward he might recover them when he came of age by paying the selling price. ${ }^{2}$ This is merely an extension of the rule governing the kin's preëmption that an heir may recover an inheritance on coming of age; his difficulty would be in finding the money to pay for his lost inheritance. It is plain that it would often be for the best interests of an heir in wardship, and sometimes necessary for his maintenance, to sell his realty. The custom at Dover and probably all other boroughs of restriction was first to sell the ward's chattels, his ships included. His tenements might then be sold, but the buyer was never (in theory) assured of undisturbed possession till the heir had passed the age of majority ( 2 to $2 \mathrm{r}$ ) by a year and a day. ${ }^{3}$

Turning again to the land of the shires, we find the kin's retrait at Nottingham, ${ }^{4}$ where the following transcript of a record of the municipal court shows how the principle worked in practice: "A. comes and claims a messuage . . in Nottingham, which $H$. bought of P., a kinsman of the aforesaid A., and offered the money given for the said messuage. And . . . H. comes

'Lyon, Dover, ii, p. 274. The customal provided that when one wished to sell his " heritage . . . the most next of his heirs shall have it before another." If the " most next" or any of the kin should not know of the sale at the time, he may come to court as soon as he does know, " and claim the bargain, [and] shall have it, by the award of the mayor and jurats, in less price by every pound $12 \mathrm{~d}$., and the seller shall make up the deficiency to the first purchaser."

2 Ibid., ii, pp. 33 I-332.

3 The buyer, however, usually held a bond of indemnification, in case of reclamation, from the guardian, who, unless appointed by will, commonly was also uneler bonds to the civic authorities for duc performance of duty.

Under any circumstances and in any borough an action for 'waste' might be brought, and such actions frequently were brought, against a guardian on the minor heir's attaining his legal age.

In the rities of the upper Rhine valley a minor heir's relations sometimes consented to sale in his place (Arnold, Geschichte des Eigentums, pl). 132-13.3). This secured the buyer from disturbance by the heir on reaching his majority, but the heir hatl his legal remedy against the relatives.

4 Rymer, Foedera, i, p. 4l; Stevenson, Records of Vottingham, i, p. 2: "quicumque burgensium teram vicini sui emerit et possiclerit per annum integrum et diem unum absque calumpnia parentum vendentis si in Anglia fueriut, postea eam quicte possidebit." Plac. Hestmon. Abbr., 1) 230, 2 I Ed. 1: "Juratores dicunt... quod . . propinquiores" who wished their deceased relatives' land must offer the price within a year and a day in the gildhall. 
and demands the money which he gave for the . . messuage, together with the costs expended upon the said messuage, according to the custom of . . Nottingham. And it is decided that . . . H. shall make oath how much money he gave," and so on to the recovery of the messuage. ${ }^{1}$ The same custom existed at Derby, ${ }^{2}$ which had customs similar to those of Nottingham in most matters. ${ }^{3}$ As would be expected Manchester, Stockport, and Salford, contiguous in situation and almost contemporary in creation, ${ }^{4}$ were boroughs of restricted sale, the restriction apparently not being confined to lands of inheritance but extending to lands of purchase as well. ${ }^{5}$ At Manchester the distinction was drawn between inheritance and purchase for sale in necessity, but, as at Northampton, it seems to have been a distinction without a difference; ${ }^{6}$ while at each of the three a burgess might sell with his heir's consent. ${ }^{7}$

1 Stevenson, Records of Nottinghaim, p. 71, a. 1310-11. See ibid., p. ror, a.1327, for a similar case.

2 Simpson, Derby, i, p. 29. In the charter of 204 the usual year and day limit of quiet possession is mentioned.

${ }^{3}$ Kingsthorpe, though it was not legally a borough, had the same custom. The place, as part of the ancient demesne, seems to have been allowed to adopt many of the customs of burgage tenure. "The ... seller of . . lands" (I modernize the spelling) " shall yield them up into the king's hand unto the behoof of the buyer . . . there to abide nine days; and if any person kin to the said seller within the fourth degree come within the said nine days and ask a cate," the tenements shall be delivered to him; he must pay the same amount as a stranger would pay and on the same day (Glover, Kingsthorpiana, p. 4I).

${ }^{4}$ The dates of their charters are: Salford, I 230; Stockport, ? I 260; Manchester, I30I. The Manchester charter is the most detailed.

5 Tait, Mediaeval Manchester, p. 66: "Quilibet burgensis burgagium suum potest . . . vendere cuicunque voluerit nisi heres illud emere voluerit; sed heres propinquior erit ad illud emendum."

${ }^{6}$ Ibid., p. 66: "Liceat cuilibet terram suam que non est de hereditate vendere . . ., si necessitas inciderit, cuicunque voluerit, nisi heres eam emere voluerit; sed heres debet esse propinquior," etc.

7 At Manchester " si forsitan heres noluerit, tamen, si necessitas inciderit, licebit ei vendere de hereditate sua de quacunque etate heres fuerit" (ibid., p. 66). The heir must buy or consent to sale if made in necessity.

The charters (customals) state in brief that (I) a burgage may be sold, (2) purchase may be sold in need, (3) inheritance may be sold in need (at Manchester), at Stockport and Salford only with the heir's consent. This looks like stupid and undiscriminating copying of the Northampton customal, though the three boroughs . in question are supposedly 'Bretollian.' 
From the Lancashire boroughs we pass to Newcastle, where the restriction on sale declared in the customs during the reign of the Conqueror's youngest son ${ }^{1}$ was still present in that of the greatest of the Plantagenets. ${ }^{2}$ The year and day limit of challenge in Henry II's charter to Lincoln shows it to have been a borough of restriction. ${ }^{3}$ The phraseology of one of the customs of York indicates almost to a certainty that it too knew the kin's retrait. ${ }^{4}$ Beverley probably followed York at this early period. ${ }^{5}$ Dunwich was a borough of restricted sale; ${ }^{6}$ Ipswich very probably was of like nature. Though its customal ${ }^{7}$ is clear on most points and is full even to repletion on a few points, it is strangely silent in respect to sale and its restriction. In

1 Brand, Neweastle, ii, p. I30, note d: "Quilibet burgensis terram suam vendat, et ire quo voluerit, nisi terra illa fuerit in calumpnia." Also "si quis terram in burgagio uno anno et una die justo et sine calumnia tenuerit, non respondeat calumnianti, nisi calumnians extra regnum Angliae fuerit, vel ubi sit puer non habens potestatem loquendi" (Stubbs, Selct Charters, p. I r 2, Customs of Newcastle. The previously quoted clause is given with slightly different wording but with the same meaning in this source also).

At Wearmouth there was the same custom (Bateson, Borough Customs, ii, p. 9r), expressed in almost exactly the same words. Miss Bateson considered this clause to mean the prohibition of the sale of a tenement concerning which a suit had been begun. Such a clause in a borough customal would be about as necessary as one compelling water to run downhill in the borough gutters. Who would buy a tenement whose ownership had yet to be decided by the courts?

Transfers of property to be legal had to be effected in the municipal court in the boroughs of restriction. There the kin might put in a challenge (calumnia). A suit followed only in case of dispute.

${ }^{2}$ C. I. H. . ii, p. 94, 3 Ed. I.

${ }^{3}$ H. M. C., Rep., 14, app., pt. 8, p. 2, a. 1157 . In the Confessor's day no one might sell his tenement outside the city and away from the kin without the kin's consent (D. B., i, f. $336 \mathrm{a})$.

"Widdrington, Analecta Eboracensia, p. 67 (customal): "There is is custom . . . that the husband may give his lands, which are of his own purchase, to his wife . . . as well as to any other person." After such a lapse of time and at this stage we have no particular interest in the burgess's wife; we have in any other person, for the implication is that the burgess may not give or sell inheritance. York and Lincoln hatd the same customs in most respects; the "same customs as York and Lincoln " is a phrase of a grant at the borough of Hedon, temp. Jolnn. The great age of these customals, even in compilation, is to be noted.

- See Poulson, Beverlac, p. 51; Rymer, Focdera, i, p. 10; Stubbs, Select Charters, Pp. $109-110(c .1121)$.

${ }^{6}$ Hardy, Rotuli Chartarum, pp. 51, 211, a. 1200, 1215; the burgesses were allowed to give or sell their "purchases of lands or tenements."

7 Le Domesday de Gippewyz. 
Ipswich in 1377 , however, a case arose which in brief was this. One John Norton had bought a tenement from John Ellis, after which he found that Ellis had an older brother, "who hathe issue alive of full age." Norton then asked the bailiffs to inquire into the circumstances of the sale, and to give him a record thereof. They reported to Norton that Ellis's father had bought the tenement, that his (the father's) wife "overlived" him and gave the tenement to John Ellis (the son) "in the presence of diverse witnesses," and also gave him "the deed of purchase." 1 It is clear from this record that when Norton found that the man who sold him the messuage had an older brother, with children, he feared that preëmption might be exercised. Otherwise he would not have appealed to the bailiffs nor would they have bestirred themselves if sale in Ipswich had lain under no restriction. ${ }^{2}$ It would seem from the evidence of both consent to sale and sale in need that Bath was likewise a borough of restriction. ${ }^{3}$ At Morpeth, ${ }^{4}$

1 Bacon, Annalls of Ipswiche, p. 79. The tenement was 'purchase' to the father. Had he died intestate it would have been 'inheritance' to the sons. Apparently the father had devised it to his wife.

2 See also ibid., p. 23, for the distinction between inheritance and purchase.

At Gloucester in II99-I 200 occurred the previously noted case which suggested restriction (see p. 54, note I). A burgess granted a messuage "with the assent of his wife and the consent of his son" (Stevenson, Records of Gloucester, p. 73). The wife's assent would be necessary, especially if the tenement were originally hers or had been acquired after marriage. The lord's consent also is contained in the grant, but neither is relevant to the point at issue. This combination of assent, with its absence from all other Gloucester grants (ibid., pp. 73-158, a. I 200-30; see the evidence under Free Sale, p. I1 2), consents too much to mean anything.

3 King and Watts, Records of Bath, pp. 9-10, a. 1218. A grant of a tenement, whose former holder had died leaving a wife and one son, required apparently two deeds to give a clear title. By the first deed the mother conveyed the tenement with the son's consent; by the second the son abandoned all claim, swearing never to try to 'aloign' the buyer or his heirs. It seems that the tenement might not be sold without the son's (the heir's) consent, and that his mother was acting as guardian.

At Bath in I 249, a deed concluded thus: "this sale now I . . have made for my urgent need, because I was charged with money due to the king " (ibid., p. 10).

${ }^{4}$ H. M. C., Rep., 6, p. 527, a. I286, a sale " in necessity." The place was aborough ante $\mathbf{1} 266$. 


\section{Woodstock, ${ }^{1}$ and probably at Alnwick, ${ }^{2}$ all boroughs of small}

' Ballard, Woodstock, p. 14. The charter of 1453 recognized the customs used " non modico tempore," one of which was that the transfer of property must be proclaimed in the borough court on three consecutive court days, and if no one appeared to challenge the purchase the buyer was secure thereafter (after the usual year and day probably). 'Purchase' is recognized as such (ibid., p. 17). Woodstock and Kingsthorpe were once both in the ancient demesne; this may explain " non modico tempore." For the following records of Woodstock, hitherto unpublished, I am indebted to Mr. A. Ballard.

"Ad curiam Portmot' tentam apud Novam Wodstoke in com Oxon xxviii die Novembris anno regis Henrici sexti tricesimo quinto venit Johannes Baret de eadem Wever et clamat tenere sibi et heredibus suis unum Gardinum cum Columbario cum omnibus suis pertinentiis in dicta villa de Nova Wodstoke quod nuper habuit ex dono et feoffamento Johannis Quenerton filii et heredis Roberti Quenerton jam defuncti. Et petit quod predictum clamum et titulum dicti gardini cum Columbario cum omnibus suis pertinentiis secundum consuetudinem dictae villae ibidem in plena curia coram Maiore et Burgensibus villac predictae solempniter et proclamari et recordari Et sic ad tunc et ibidem dictum clamum et titulum proclamat' et recordat' sunt primo vice Et insuper videlicet ad curiam portmot' tentam ibielem xii die Decembris dicto anno similiter proclamat' et recordat' sunt et dictum clamum et titulum modo et forma ut supra in plena curia secundo vice $\mathrm{Et}$ ulterius moflo at curiam Portmot' tentam xxvi die Decembris dicto anno venit dictus Johannes per Ricardum Alderley Attornatum suum Et petit dictum clamum et titulum tertia vice proclamari secundum consuetudinem dictise villae et sic in plena curia tertia vice proclamat' sunt predictum clamum et titulum ut supra Et (quod nullus neque aliquis sedente curia venit dictum clamum et titulum sic tertia vice prodamat' secundum consuetudinem dictae villae contraelicere seu calumpniare Ideo secundum consuet udinem predictae villae a tempore cujus contraria memoria hominum non existit usitatam predicta clamum et titulum per Johannem Anstyn tunc majorem predictae villae Johannem Birde Armigerum et Ricardum Dogett Alderman et alios Burgenses ad tunc et ibidem per presentes approbat' testificat' et recordat' et irrotulat' existit pro qua quidem probatione et irrotulatione predictus Johannes Baret dat domino Regi de fine . . . iii d lit etiam per predictum Johannem Maiorem Johannem et Ricardum Aldermannum secundum dictam consuetudinem Adjudicatum est quod predictus Johannes Barct predictum (iardinum cum Columbario cum onnibus suis pertinentiis habeat gauleat possideat et teneat sili ('t heredibus suis in perpetum. In cujus rei testimonium huic presento scripto sigillum conmune dictae villate est appensum hiis testihus Johanne Bexher Willelmus Taillor et Willelmus Heyner et aliis Datum apud Wietentoke praedicto dic et anno supradicto."

\section{Vea Hoodstock. Form of Proclamation.}

"All men take knowledge for the right title and interest of Thomas Best and his heirs of and in One tenement with a close the which he purchased of Mr. Edward

2 Tate, Alnwick, i, p. 9.3. A tenement was sold as of purchase, and the seller promised on his heir's part not to cloign. The loorough had the customs of Newcastle; it was chartcred by William de Vesci, $1157-85$ (ibid., p. 96). 
importance and scanty records, restriction was probably the rule.

The boroughs of Ireland fall into two groups. In those which had the customs of Bristol and Dublin (Waterford, Limerick, Cork, and Rathcool are the only important ones in our period) sale was free. In many, and almost certainly in all, of the rest it was limited to lands of purchase. Thus at Inistiogue sale of lands of purchase was permitted, ${ }^{1}$ so too at Wexford, ${ }^{2}$ while at Drogheda 'versus Uriel' the charter seems to have allowed the kin's preëmption for both purchase and inheritance. ${ }^{3}$ No one of these charters goes far into detail in respect to the kin's preëmption with its rules. One charter notes the year and day, another the distinction between purchase and inheritance; there they rest their cases. The case for restricted sale in all the boroughs of Ireland, except Dublin and its followers, seems well made, however; an additional point of the evidence therefor is that these towns had, or thought they had, the laws of Breteuil, where possibly purchase, but not inheritance, might be sold without the kin's consent.

It seems that nearly every part of England had one or more boroughs where the kin's retrait existed, from Dover and Ports-

Chamberlayn Esquire The which tenement aboundeth upon the Park Wall of the west part and of the North part the High Street and of the East part a lane going into the Common Green and upon the South part aboundeth upon a garden ground late the Chantry's now in the holding of one John Fletcher Now if there be any man that can make any claim or title let him come \& claim and he shall be heard according to the form of law or else it is adjudged to the said Thomas Best and his heirs for ever according to the custom of this borough time out of mind."

1 Gale, Corporate System of Ireland, app., p. xii. The prior conceded to the burgesses the privilege "omnes conquestus [acquisitions] suos dare vendere . . salvis serviciis . . . que michi debentur."

${ }^{2}$ Ibid., app., p. xvi. The charter was from the Earl of Pembroke. See for these charters, Chartae Hiberniae.

${ }^{3}$ Ibid., app., pp. vii-viii: "if any person shall have held any tenement within the bounds of the ... borough, either by gift or purchase, or from inheritance, for ... one year and one day ..., and there shall have resided any one in . . Ireland claiming . . . a right in the said tenement, who shall be of full age and free of body, and not sickly, and he shall have made no challenge thereto within the term aforesaid, but shall have maliciously withdrawn himself, he shall lose his challenge." The "full age, and free of body, and not sickly" defers the limit of challenge on the part of a minor, or an heir in jail, or one who is sick. Perhaps wilfully withdrawn' is better than ' maliciously withdrawn.' 
mouth on the south to Newcastle on the north, from Ipswich on the east to Tewkesbury on the west. The midland boroughs show it as well as the Lancashire towns; but there is little evidence for either freedom or restriction from the western towns on the Channel coast. In time, the records run from the Confessor's day, though even then there were boroughs where apparently the kin's retrait did not exist. ${ }^{1}$

As to the nature of the sources little complaint can be made of customals or charters and records of courts. Records of transfer of realty are often hard to analyze. Such expressions in deeds and grants as inheritance, or purchase, or necessity, may have been required by a then existing custom, they may be survivals of one that is going or has gone, or they may mean nothing at all. ${ }^{2}$ The appearance in a deed of some expression suggestive of the kin's retrait needs corroboration before being accepted as proof of its presence. On the other hand the absence of such phrases from records of transfer in any borough is not proof that sale therein was free; the grants may all be those of lands of purchase, which were saleable nearly everywhere.

In connection with this subject two important points or questions may suggest themselves. Why did the kin's retrait appear in the charters (or customals) of some boroughs and not in those of others of about the same age and character, and what did this restriction actually mean? Charters to the boroughs by prescription have no place in this discussion; tenurial matters are seldom contained in them; even though they should be, they merely state some custom of the borough. The charters to the boroughs by charter, whether they confer the burgage tenure on a vill or on a previously non-existent town, must either contain definite customs (many attempt this in detail) or grant those of some other borough, leaving it to the burgesses to decide how much or how little of such they shall adopt. In neither case does there appear reason to think that the lord of

${ }^{1}$ D. B., i, f. $337 \mathrm{a}$, Torskey. T. R. I. the burgesses of Hereford needed the consent (to sale) of the pracensitus and probably of the kin, but restriction had vanished before mid-. Ingevin days.

2 Just as grants from one burgess to another for his 'homage and service' are meaningless. Burgesses did not do homage or even swear fealty to each other. 
a chartered borough ever purposely imposed the kin's retrait on his burgesses; it could advantage him nothing. ${ }^{1}$ It seems that the restriction of the kin's retrait was present in any borough, chartered or prescribed, because the burgesses wanted it there; it was a feature of the old Germanic land law, and even in the thirteenth century only progressive boroughs had got rid of it. ${ }^{2}$

As to the actual meaning or effect of the kin's preëmption, suppose that all the tenements in a borough are of inheritance. ${ }^{3}$ Families may become extinct; there will be escheat. Burgesses may be convicted of felony; there will be forfeiture. When the tenements are regranted they are no longer of inheritance, and where purchase may be devised, they seldom need become inheritance again. ${ }^{4}$ This is the case in the early stage of borough development. As commerce grows, as the mercantile spirit begins to infect the land, the kin's retrait is felt to be a burden. The plodding farming days are passing, a change must be made in the custom. It is made, and an heir's consent allows inheritance to be sold. He may refuse, and 'selling in need' begins. When, is not of so much moment; soon enough to appear in the earliest customals. It must have made the kin's preëmption a mere phrase ${ }^{5}$ even at a comparatively early period, being invoked as a legal fiction like the fiction of being obliged to pay a debt to the king in order to get the Exchequer's speedy execution.

The next step in many boroughs (those of free sale) seems to have been either to ignore the kin's retrait, or, which is more likely, formally to change the customal. ${ }^{6}$ Apparently the kin's

1 He might, however, issue a prospectus, as it were, for a new borough with the 'customs of' (say) 'Bristol' before consulting the newcomers, but as far as these customs were kept out of the charter so far the burgesses could make them what they pleased.

${ }^{2}$ At Bury Saint Edmunds in Irgo, Abbot Sampson's charter contained the kin's preëmption because it had existed in King Edward's day, so the burgesses said, which was true. When they extorted another charter in 1327 they retained retrait lignager.

Of boroughs founded in Ireland at about the same time some were boroughs of restricted and some of free sale.

${ }^{3}$ A possibility in a newly-created borough.

- They commonly did so, however.

5 Court records show no need to prove ' need,' but only to affirm it on oath. .

${ }^{6}$ Non-observance and non-enforcement, opposition and change; the usual 


\section{preëmption existed in London early in the twelfth century,} but its disappearance soon after was too rapid to allow its appearance in Liber Custumarum. London, however, is not typical of English boroughs, and in many places the distinction of purchase and inheritance lasted long. The frequent promises of sellers not to try to eloign the buyer or his heirs may have served to preserve its memory, and it probably lingered in backward boroughs till mediaeval days had gone. ${ }^{1}$

steps in legal progress. Unless their customal had been embodied in a charter the burgesses could change it themselves. See Stubbs, Select Charters, pp. Iro-i I I.

1 That the kin's preëmption disappeared from the land law of the country in the course of the thirteenth century (Pollock and Maitland, Mistory of English Law, i, p. 647, and ii, p. 313) is certain. It may be asked then why it appeared in Woodstock, where it was said to be a custom used " non modico tempore" and which town did not become a borough till the fifteenth century, and in Kingsthorpe which was never a borough at all. Possibly its continuance in such places, in which it had existed for no short time as the townsmen said, was due to the fact that both were in the ancient demesne and may have been allowed to retain the kin's retrait. It is very improbable, however, that the royal courts would have upheld them in the practice. Sir F. Pollock has suggested (see my articles, part ii, in the Law Quarterly Review of October, 1910, p. 347) that this survival may be due to " unthinking imitation of prevalent borough customs."

In a few baronial or episcopal boroughs the lord's intervention had at one time appeared at the sale of a burgage, as at Pontefract where livery of seisin was through the lord (H. M. C., Rep., 8, p. 269, 5 Rich. I; “Quilibet burgensis poterit terram suam . . . vendere . . . et pretor dabit terram emptori de dono domini "), or rather his bailiff, who, however, seems to have been a wholly involuntary medium of transfer.

At most of these places this intervention by the lord of the borough lay in the necessity of his license to sell. This restriction, however, soon passed into a salutary check on alienations in mortmain, or else the town and not the lord became the licensor. 'Thus at Walsall, c. II97 "if anyone of the said burgesses shall desire to sell his burgage, he shall make it known to us or to our bailiff" (Willmore, W'alsall, p. I60). In $\mathrm{I} 308-09$ the town had taken the place of the lord. At Salisbury temp. Ilenry III the license of the bishop was necessiry for any sale, but in 1305 his license was not needed except where mortmain might follow: "non liceret civibus . . . burgagia vel tenementa . . . in eadem Civitate ecclesiis vel viris religiosis dare vel vendere . . sine voluntate et licentia . . E Episcopi" (Hoare, IIstory of Modern Wiltshire, vi, p. 740). At Chard the bishop (Bath and Wells) retained the right to consent to this sort of alienation (C.P.R., $a$. 1286, p. 210$)$.

At Bury Saint Elmunds in I I 90 the charter allowed sale " necessitate cogente ... sine . . . licentia pracpositi" (I)ugdale, Monasticon, iii, p. 154), as if such license had been necessary at a previous period. 


\section{INPENNY AND OUTPENNY}

Alienation fees as paid to the borough lord have been discussed among the incidents of the tenure. There were boroughs where a fee at alienation, called at Norwich 'inpenny and outpenny' was exacted by the community. ${ }^{1} \quad$ A fee of this sort was charged at Preston, ${ }^{2}$ where one who took up a 'void place' was obliged to build thereon within forty days on pain of forfeiture, and at Chesterfield. $^{3}$ In these places and in Norwich only new-comers need pay this fee; it was not charged at transfer among burgesses of the same town. The burgesses of Hereford denied that they exacted entrance fees from foreigners, but the bailiffs and the town-clerk were paid for witnessing seisin. ${ }^{4}$

At a number of boroughs fees were charged at alienation, though of a very different amount and wholly different nature from those mentioned hereinbefore. It is probable that they were collected at every sale of realty, for the boroughs in which they occur are among those of restricted sale, where the kin's preëmption enforced publicity of alienation. In some cases, however, their customals state the requirement of a fee only under special conditions. At Sandwich when a tenement which a wife had brought at marriage was sold, a percentage of the price was paid by both buyer and seller, and the town-clerk "should

1 Hudson and Tingey, Records of Norwich, i, p. 229. In I 286 Walter son of Nicholas of Norwich granted a messuage to John of Yarmouth and "predictus Walterus dedit Ballivis Norwici unum denarium de jure suo exeundo et predictus Johannes dedit eisdem ballivis unum denarium ad jus suum intrandum secundum consuetudinem . . Norwici." See ibid., p. 242, a. I 289 for the same custom.

2 Hardwick, Preston, p. 259: "If any one wish to be made a burgess, he shall come into court and give to the mayor $12 \mathrm{~d}$., and shall take his burgage from the mayor."

${ }^{3}$ Yeatman, Records of Chesterfield, p. 40. A stranger who bought a messuage must satisfy " the Burgesses set out in their ancient manner." Burgesses' heirs who had paid $3 \mathrm{~d}$. a year for freedom to trade paid 6d. each on taking up tenements (ibid., p. 39). A burgess's heir was not allowed to hold the tenement during his father's lifetime (ibid., p. 39, 22 Ed. I); the aim may have been to restrict the term burgess to the actual freeholder.

${ }^{4}$ Johnson, Customs of Hereford, p. 26. A foreigner need pay nothing for " having ingress into the same " (a messuage), "but only r $2 \mathrm{~d}$. to our bailiff . . . for witnessing the seizin, and so much also to our town-clerk." 
also be considered "; ${ }^{1}$ Romney and probably the rest of the Cinque Ports had a like custom for a similar condition, but the seller alone paid the fee "to the comen" (community) "and the clerk." 2 At Northampton, in addition to the chief lord's ' sellings,' a fractional fee was charged by the town ${ }^{3}$ at Maldon the lord sold his right to alienation fees to the burgesses. ${ }^{4}$ From an economic standpoint these fees are but a small restriction on the mobility of urban realty; even in the early part of our period they did not form a high percentage of the prices commonly paid. A fixed fee of $4 \mathrm{~d}$., that of many of the smaller boroughs, could be no great obstacle to him who wished to buy or sell. When we turn to the larger boroughs and those of the south coast we seem to leave the middle ages behind us. There is no fixed fee, as if most burgages were alike in size and in poverty, but a percentage, one-sixtieth to one hundred and twentieth of the selling price, charged for registration of the deed.

We have here two sorts of alienation fees payable to communities, the fixed and the fractional, the latter being a charge for registration or witnessing seisin; and though the evidence is

I Lyon, Dover, ii, p. 307. The sale must go on record "agreeably to the form of levying a fine in the king's court," and the fee was " $4 \mathrm{~d}$. in the pound of silver, viz. 2 l. from the buyer and $2 \mathrm{~d}$. from the seller."

${ }^{2}$ Ibid., ii, p. 335. The amount of the fee is not stated. A grant or conveyance (see Boys, Sandich, p. 524) shows how exact and careful the mayor and jurats were in such cases.

It is said that, in the twelfth century one who bought land in London must pay 2s. to the ward alderman (Bateson, Borough Customs, ii, p. 81). If so, this fee is hard $t)$ (lass, for it is neither sellings nor a registration fee, the latter being paid at the Ilustings.

At Beverley, where the (iild Merchant seems to have governed the borough, it was urdered in $13^{6} 7$ that he who became free of toll by purchasing $100 \mathrm{ft}$. of land should come to the town hall, show his deed, paty 4 d. to the community for entrance, and 21. to the derk (Beverley Toun Documents, p. 79). There is no evidence for an entrance fee before 1307 .

${ }^{3}$ Markbam, Liber Custumarum, p. $3^{6}$. He who bought "londe tenement or rentis " must pay 2 d. in the pound "to the profyte of the toun."

' C. P. K., a.1403. Pl. 307-308. The fee, called 'landchepe,' was rool. in the mark, paid ly the buyer. The bishop of London was lord.

At Kingsthorie "yf any man [ex]chaunge any . . tenement, and any bote be hadde unto the sume of $\mathrm{ii}$ (l. and above, so after the quantyte as yt ys above to paye seeson" (Cilover, Kingsthorpiana, p. 42 ). An alienation fee was paid on the difference in price at exchange, and probably also at simple sale. 
scanty, it seems strange if many boroughs enrolled deeds without requiring a fee of some sort. ${ }^{1}$ Between the fee as exacted by a lord and that as charged by a community there is a wide difference in origin. Though in some boroughs the right to make profit of transfer of tenements may have passed from the lord to the burgesses, there is no evidence that such was the case at any but a few places of small importance, ${ }^{2}$ most of which seem to show Norman custom in their fixed alienation fees. Both fixed and fractional fees existed in Normandy; ${ }^{3}$ the fixed fee may have been an importation into England from across the Channel. If the fractional fee came from the same source, it must have lost weight tremendously in the passage, for in the villes of Normandy the lods et ventes were one-twelfth, five to ten times greater than registration fees in Northampton and the Cinque Ports. Instead, then, of looking for shadowy derivations, it seems better to take the facts as they are. In a few boroughs, mostly of the backward sort, a fixed fee was charged at the alienation of a tenement; in some, and probably in the majority, of the larger boroughs a fractional fee was levied for recording a deed; for most of the boroughs the evidence is too scanty for proof. ${ }^{4}$

1 Enrolment was almost universal: any compilation of burghal records (see appended bibliography) provides abundant evidence.

2 At Maldon the lord (bishop of London) sold to the burgesses his right to take such a fee. Both town and chief lord (usually a burgess) got fees at Northampton.

3 One need not stop with Normandy. The rule for northern European towns was that, when alienation fees existed at all, they were fractional in natural and fixed in artificial towns.

4 There are a few legal records of land transfer in extra-burghal courts. In 53 Henry III a "final concord was made at Westminster" in respect to a messuage in Cambridge (C. I. M., i, p. 227). The Norfolk Feet of Fines contain several records of transfer of messuages in Norwich and its suburbs, 24, 36, 40, and 42 Henry III (Stanley v. Mayor of Norwich, etc., ff. 6, 7). As late as the second half of the sixteenth century there are conveyances by indenture in London (H. M. C., Rep., 9, pt. I, p. 5), but these were probably in the Hustings, it and other borough courts often using that method.

Every borough of consequence had the sole right to hear and determine pleas of land within its bounds, and burgesses who tried to carry their cases outside were often haled back by the civic authorities. The final concord at Westminster may have been settlement of an appeal from the borough court at Cambridge. The Norwich cases apparently had never been before the court of that borough, other- 


\section{Free Devise}

In one sense this peculiarity of burgage tenure was its most important feature; the right to ' make a devise of land ' or ' make an heir' was regarded by both Glanvill and Bracton as the special and peculiar feature which marked off the tenure of the boroughs from the tenures of the country. ${ }^{1}$ Bracton seems to have thought that freedom of devise existed in every borough in England. As we proceed, however, we shall find that there were many boroughs where only certain sorts of tenements might be willed, and some where devise of realty was unknown. Probably when Bracton was compiling his De Legibus Angliae he had London and a few other large boroughs in view, in which there was certainly complete freedom of devise in his day, and no doubt long before. Whether as commentator or as justice. he would seldom have the matter of wills of lands and tenements presented to his attention. This may serve to explain why his statements in respect to burghal devise are contradictory; ${ }^{2}$ for wills of land were enrolled as a rule in the borough courts, and disputes concerning their validity were settled there.

wise they would have been taken, like other records in this case (Stanley $r$. Mayor, etc.) from the rolls of the borough court. As long as no one questioned its origin the foot of the fine in each case would be a valid deed of transfer. Should a dispute arise the feet might be set aside as not being records of a court of proper instance or of one not having jurisdiction.

1 Devise of chattels was the same within or without the borough bounds during the mediacval period and remained under restrictions in the boroughs till the close of the seventeenth century ( 4 and 5 William and Mary), long after these restrictions had been abolished in the country at large. Cf. compurgation in the boroughs with corresponding jury trial in the country. See Gross, "Modes of Trial in Mediaeval Boroughs" (Hariard Law Review', xy, pp. 691-706). 'The boroughs may have led. but they also lingged.

2 Britton states that inheritance might not be sold in Lonclon (Nichols, Britton, i, p. 174, note) yet that does not make it so. Both Britton and Bracton - in one sense they are the same - state that inheritance in London might be neither sold nor bequeathed. Says the latter, after stating that purchase may be berueathed: "Secus tamen est in quibusdam locis si perveniant ex descensu antecessoris, in quibusdam locis sicut in civitate Londoniae" (De Legibus, edited hy. Sir Travers Twiss, vi, p. 214). Previously, if Twiss edited in the order in which Bracton wrote, he had said, " revera terminatum est quod potest legari ut catallum tam haereditas quam perquisitum per barones Londoñ et burgenses Oxoñ "(ibid., iv, p. 264). 
Wills are not very frequent among the earliest land documents, even in London and other large towns. The primitive burgess seems usually to have been content to let the custom of the borough ${ }^{1}$ take its course in regard to intestacy; and even where wills were common, the oldest have often been destroyed or lost. ${ }^{2}$ With the twelfth century the practice of devise increased, and soon no important borough was without a greater or lesser number of wills of realty. ${ }^{3}$ The sources for this part of our subject are of the same sort, except where wills take the place of grants and conveyances, as those used in the matter of free and restricted sale, and present almost the same ease or difficulty of interpretation. ${ }^{4}$ The distinction of lands of purchase and lands of inheritance, with freedom for the former and restriction for the latter, ran a course in devise nearly parallel to that in sale, with this important difference, however, that free devise was almost everywhere a later development of the borough land law than free sale. If, therefore, sale of lands of inheritance in any particular borough lay under the limitation of the kin's retrait, it must, in the absence of records, be assumed that lands of purchase alone could be devised at that date. Later, a change in the customal, perhaps never formally recorded, might abolish restriction in part or in whole.

Whatever the case may have been at an early period, the York customal makes no exception or limitation in stating that devise was free, ${ }^{5}$ nor was 'inheritance' made the ground of action

Elsewhere (Maitland, Bracton's Note Book, ii, p. 65) he had noted a case which turned on the acknowledged freedom of devise in London in I 219.

Possibly the method of proclaiming (enrolling) a devise of land in the Hustings may be a relic of the vanished restriction. There is a Calendar of Wills Proved and Enrolled in the Court of Husting, London, 1258-1688, edited by R. R. Sharpe. The Hustings still enrolls deeds.

I Sometimes primogeniture, sometimes Borough-English, sometimes equal division of tenements.

2 See Matthews, Cardiff Records, iii, p. 99. All the old deeds in Cardiff were destroyed by fire.

3 All sorts of oddities in the way of devise can be seen in an old work by Henry Swinburne, A Treatise of Testaments and Last Wills (4th ed., I677).

4 See p. III.

5 Widdrington, Analecta Ebor., p. 70: "all the lands, tenements, and services within the city and suburbs ... are devisable by the usage of the . . city; 
in an attempt to have a will set aside by the court. ${ }^{1}$ Possibly devise was free at Congleton; ${ }^{2}$ it certainly was at Wycombe, if the jurors made true deliverance before the royal justices. ${ }^{3}$ The Hereford customal distinctly implies that devise in that city was free. ${ }^{4}$

At Bakewell tenements might be bequeathed, though apparently only to fellow burgesses. ${ }^{5}$ At Hull, the only borough (Overton excepted) of royal foundation, ${ }^{6}$ at Chard, ${ }^{7}$ and at

and the citizens may devise them." He who held a tenement jointly with another might devise his part without making severance.

In $1286-90$ the townsmen of Bootham, one of the suburbs of York, said that their tenements " be devisable by will" (ibid., p. I2I), making no distinction as to purchase or inheritance. The men of York said they devised their tenements " tanquam catalla sua " (ibid., p. 58). No doubt sale too was free at this period though restricted at an earlier date. See text, p. I 20.

1 Widdrington, Analecla Ebor., p. 69, 20 Ed. III. A son unsuccessfully claimed his father's freehold because it had been devised away from him by nuncupative will. Still, the messuage may have been 'purchase.'

Notwithstanding the statement that "all tenements" might be devised I doubt strongly that this was the case. If Widdrington had quoted the Latin of the customal, or even given an approximate date, one might be surer. York was not a progressive city and free devise does not precede free sale. If such freedom existed, it must have been late in the middle ages; the evidence rings hollow, it is counter to the genius of the place.

2 Head, Congleton, p. 34, $a .1272$. Henry de Lacy's charter allowed his burgesses to "alienate [messuages] at their Will, except to religious Persons." This is not conclusive evidence; alienation may have been only among the living.

${ }^{3}$ Plac. W'estmon. Abbr., p. I88, 2 Ed. I: "juratores requisiti si consuetudo sit ... dicunt quod aliquis ... [habens actatem] potest ... terram suam ... legare."

- Johnson, Customs of IIereford, pp. 25, 34. The implication concerns the case where an offender's chattels have not been enough to pay his amend, and his tenement has been taken into the hand of the king and commonalty, its revenue being used to make up the deficiency. The heir may enter such a tenement, but it must not be devised till the amend is paid. While the customal does not state that cither purchase or inheritance was devisable, an addlitional reason for supposing devise to be free is that sale was free. Furthermore there was in strictness no heir to a purchase until its holder died.

5 II. M. C., Manuseripts of the Duke of Rulland, iv, p. 4 I, a. I 286. W. Gernun's charter grinted "that they may . . bequeath . . . their burgages when they will and to whom they will of the liberty of the said town." The last phrase was probably only an indirect methol of preventing devise in mortmain.

${ }^{6}$ Sheahan, Ilull, p. 50. The burgesses may "dispose of to whomsoever they please " their tenements " in their last wills and testaments."

${ }^{7}$ C. P. R., a. 1286, p. 2 i6. Chard had been a borough for some time. The lord of the borough, the bishop of Bath and Wells, gave the privilege of free devise by charter in 1280 , but forbade devise in mortmain. 
Scarborough ${ }^{1}$ liberty of devise was the rule. At Altringham devise seems to have been free; ${ }^{2}$ at Bridgnorth it was possibly the same; ${ }^{3}$ at Berwick lands and tenements might be bequeathed anywhere. ${ }^{4}$ Notwithstanding its so-called historians, it is only by grace of a quarrel over taxes in I Edward II that Canterbury ${ }^{5}$ appears among the boroughs of free devise. At Cambridge ${ }^{6}$ the right to devise inheritance appears to have come as a royal gift. Free devise, however, had long been practised; the king's concession, one among several other privileges, seems to have been only a hook on which to hang a prohibition of bequest in mortmain. At Lynn ${ }^{7}$ inheritance seems to have been devisable.

A private dispute at Dublin serves the purpose of the public difference at Canterbury, and shows devise in that once Danish city to have been free, the custom being declared by the civic authorities. $^{8}$ At Bristol, between whose customs and those of

1 Plac. Westmon. Abbr., 32 Ed. I, p. 297 and Brown, Yorkshire Inquisitions, iii, pp. 9I-93. The defendant " dicit quod est consuetudo ibidem quod aliquis potest legare terras suas."

2 Parliamentary Papers, 1835 , xxvi, p. 2574: "quod singulus burgensis burgagium suum possit ... in testamento assignare cuicumque vel quibuscunque voluerit."

${ }^{3}$ C. $I . M .$, v, p. 46,2 Ed. II: a messuage was bequeathed to a daughter to the exclusion of a son who was the devisor's heir.

${ }^{4}$ C. C. R., iii, p. 27, a. 1302 .

${ }^{5}$ Exchequer Plca Roll, no. 30, m. 9. The dispute was between the citizens proper and the men of Stablegate, who, said the former, always paid tallages with them: "et hoc liquet manifesto quia dicunt quod homines de Stablegate semper temporibus retroactis hucusque tenementa sua in testamentis suis legarunt et legant ut cetera catella sua prout ceteri cives ejusdem civitatis fecerunt et faciunt." See also H. M. C., Rep., 9, pt. I, p. $7_{7} \mathrm{x}$ for freedom of devise between husband and wife.

${ }^{6}$ Plac. Westmon. Abbr., p. 324, 9 Ed. II: "et in isto brevi continetur quod dominus Rex concessit quod omnes tenementa infra burgum Cantabrigiae habentes . . . in ultima voluntate sua in testamento suo quibuscumque legare valeant," etc., except in mortmain. Cooper (Cambridge, i, p. 74) assigns this 'gift' to 1313 .

7 H. M. C., Rep., I I, app., pt. 3, p. I88. A charter which granted the privilege of enrolment of wills in the gildhall speaks of the burgesses as " having been heretofore accustomed to bequeath by will their tenements in the said burgh according to custom." 9 Ed. III.

${ }^{8}$ Gilbert, Records of Dublin, i, p. 489, a. $\mathrm{r}_{4} 83$. The prior and convent of the cathedral on the one hand and a burgess and his wife on the other claimed a messuage which had been devised to the wife by her first husband. The religiosi, 
Dublin there was so strong a resemblance, inheritance might be willed. ${ }^{1}$ Both Bristol and Dublin seem to have reached the rank of towns of free devise during the latter part or soon after the close of the thirteenth century. At Bristol certainly, and at Dublin probably, the burghal land law of an earlier period, though apparently sometimes evaded, allowed devise of purchase alone. ${ }^{2}$ At Hedon in the East Riding, whose customs closely followed those of York, devise was free; ${ }^{3}$ at Bath like liberty seems to exist in the later part of our period. ${ }^{4}$

At Nottingham the evidence which relates to devise is of a sort that leaves the matter somewhat uncertain; possibly inheritance might be willed toward the end of the fifteenth century; ${ }^{5}$ though the fact that sale was restricted as late as notwithstanding that devise in mortmain was forbidden, persisted in their claim and drew from the mayor and bailiffs the declaration that tenements in Dublin might be bequeathed anywhere except in mortmain.

${ }^{1}$ C. I. M., Henry VII, i, p. 294, 7 Henry VII. "All messuages . . . therein" (i. $e$., in Bristol) "can be devised and bequeathed by the will of the persons seised thereof."

${ }^{2}$ See Roberts, Calendarium Genealogicum, i, p. 313. In 9 Ed. I John de Lidiard wilted a messuage, which had come to him as his brother's heir, to his wife Johanna, "quae tenementa praedicta Johanna clamat tenere ratione testanenti... Johannis, in quo continetur quod ipse ei ea legavit et tamen contra consuetudinem . . Bristolliae." There is nothing to show that Johanna had to relinquish the messuage. In 1428 the reversion of an inherited tenement was devised at Bristol (Bickley, Calendar of Bristol Deads, pp. $81-82$ ). In ${ }_{1} 361$ it was stated (Bickley, Little Red Book of Bristol, i, p. 94) in connection with a suit over disseisin, that devise was free.

3 Boyle, Hedon, p. 50, a. 1348 . A charter allowed the burgesses " frecly" to "berpeath all their lands, rents and tenements . . and also their chattels." The mention of chattels seems superfluous: probably the original phrase was "tanquam catalla": much depends on the "all." Hedon was a borough temp. Henry 11 .

4 King and Watts, Kecords of Bath, 1. 25. Cir. 1,400 there was a lease of at tenement which hat been bequeathed to the corporation by one who appears to have inheriterl it.

5 Plac. Hestmon. Ibbr., p. I 80,50 Henry HI. Before the royal justices R. "dicit yuod comsuetud" burgi Nottingham talis est quod si homo vel femina habuerit terran vel tenementun potest illud vel illam . . . legare." Parties to a suit are not always impartial witnesses however.

In $1335^{-3} 3^{\text {f) }}$. Ignes, widow of Richard de Grimston, sought possession against Thomas de stafford and his wife letia of a third part in the lirench borough and a fourth part in the linglish borough (dower in each) of a preposterous amount of realty. The defendants had possession, in the English borough only, of about 
the middle of the fourteenth century ${ }^{1}$ leaves the impression that the custom at Nottingham may have been halting between two opinions, or perhaps entering the stage of transition. Whatever it may have become at the beginning of the modern period, it was probably a town of restricted devise throughout the middle ages.

There is throughout our period more variability in the matter of devise than in that of sale. Freedom of devise was a later development of the burghal land law, often so late that it escaped the compilers of the customals. It will be noticed that a few of the boroughs of free devise appear in the roll of towns of restricted sale. In such boroughs the evidence concerning sale comes mainly from the twelfth and thirteenth centuries, the evidence in respect to free devise from the fourteenth and fifteenth. The sources also differ, devise oftener than sale being a subject for adjudication by the courts.

\section{Restricted Devise}

Where lands of purchase might be sold freely, the rule in all the boroughs of England with the exception of Northampton and a few lesser towns, they might be freely willed. There was, however, a group of boroughs where devise of either sort of tenement seems to have been unknown. This is practically a certainty in respect to many of the boroughs of Ireland, ${ }^{2}$ with a few in England, and is a high probability in regard to other English towns. Whether in England or Ireland, they are all included in one class, that of chartered and usually created baronial or abbatial boroughs, showing strong traces of Norman influence in their charters or customals. Most of them were

two per cent of the property demanded, concerning which they rested their defence on the fact that the messuages were theirs by will. The tenements had been bequeathed to Thomas; this would have been unnecessary had he been Richard's heir. If they had been of purchase Thomas would surely have said so, or Agnes that they were not, if inheritance had been undevisable. Thomas's defence was that the tenements were " bequeathed ... according to the custom of . . Nottingham " (Stevenson, Records of Nottingham, i, p. 125).

1 See p. 118.

2 All except Dublin and its daughter-towns, Waterford, Cork, Limerick, and Rathcool. 
founded in the twelfth century; not one of them is of importance at any time in the middle ages.

They include the Bretollian boroughs - Wexford, Inistiogue, Drogheda, and other small Irish towns, ${ }^{1}$ with Barnstaple and other boroughs in England. On account of a certain clause in their charters, they have been credited with the custom of free devise, ${ }^{2}$ when in fact all that this clause provided was that no burgess should so use his tenement as in any way to injure his neighbor. ${ }^{3}$ Furthermore all the Irish boroughs of our period, with many small Welsh and English towns, were Bretollian, in part or in whole, save Dublin and its followers which were Bristollian. In the villes of Normandy, Breteuil among them, devise of any sort of tenement was then unknown. ${ }^{4}$ It is possible, however, that devise crept into some of these boroughs during the later part of our period, devise of purchase at least, in imitation of the English custom in Dublin or Bristol, for their charters did not forbid devise; they simply did not know it.

Such was the case at Barnstaple, a borough almost as Bretollian as the boroughs of Ireland; in that town tenements were bequeathed early in the fifteenth century. ${ }^{5}$ At Barnstaple,

1 See Gale, Corporate System of Ireland, app., pp. xi, xiv, etc.; their charters are also in Chartae II iberniae.

2 See Bateson, Borough Customs, ii, p. 92. The clause in question rearls " liceat eisdem burgensibus de tenementis suis que tenent in burgagiis suis [sometimes burgagio suol sine injusto gravimine vicinoribus suis disponere sicut sibi melius viderint expedire, sive edificia, sive [h]ortos ..." (see Gale, Corporate System of Ireland, app., p. xii et pass.). Miss Bateson considered 'disponere' to mean ' dispose of by will," supplying the last two words gratuitously. Both lords and burgesses would have wondered at this interpretation, especially as the sale of purchase alone was allowed. In addition 'disponere' was not the usual term for devise in borough clarters or customals, and when used at all was always followed by ' in testamento (ultimo) suo.' There are very few instances of even this use: 'legare' was the common term; sometimes 'devisere.'

${ }^{3}$ At Jublin (Gilbert, Records of Dublin, i, p. 5) there was a like condition in respect to the use of messuiges: " Every citizen may, for his own advantage, build wherever he wishes on the bank [of the river], but without damage to the city or citizens." The citizens of bublin were forbidden to devise their lands "to houses of religious orders, or to persons unable to aid the city in time of need " (ibid., i, p. 220 ).

- Génestal, La Tenure en Bourgage, p. 172.

' H. M. C., Rep., 9, pt. 1, p. 208, a. 1422. 
however, there appears to have been opposition to devise; it seems that the burgesses took the matter into their own hands, having lost patience over previous and unsuccessful attempts to obtain this privilege by petition presented in Parliament. ${ }^{1}$ In Cardiff, and probably in Tewkesbury, both of which had Norman or partly Norman customs, though the charter (customal) was highly detailed, it contained no word of devise of either sort of tenement; very probably restriction was complete. ${ }^{2}$ In Manchester, Stockport, and Salford a tenement might be devised only when its holder had no heir. ${ }^{3}$ In Salford and Stockport, and probably in Manchester also, ${ }^{4}$ a fee of $4 \mathrm{~d}$. was paid by the devisee. These three boroughs, each of which was or wished to be Bretollian, show that the dawn of the English custom of devise had begun to enlighten the darkness of Bretollian ignorance. ${ }^{5}$ Had these boroughs been chartered in the

1 Barnstaple's historians, though accurate in a few minor points, contradict each other, and the central authorities' account of the matter as well. One of these narratives (Chanter, Barnstaple Records, i, p. 139) tells us that an inquisition in 14 Ed. III found that "the burgesses of the said town ought not nor have hitherto used to bequeath their tenements in the same borough in their testaments." True so far. The next statement, - that in 17 Ed. III the burgesses petitioned the king successfully for certain privileges, among them being one which allowed them "to bequeath their tenements ... to whom they will" (ibid., i, p. I40), is wholly astray. Another and better account (Gribble, Barnstaple, pp. 342, 376) tells somewhat the same story, but postpones the gift from the king, "for a fine which they [i.e., the burgesses] have made with us," till 1444 , though realty had been devised some twenty years before that date. It is true that in 1343 an inquisition was taken in answer to a petition from the men of Barnstaple presented in Parliament, but nothing followed, the finding being unfavorable (C. P. R., a. I343, p. 90). The next year another inquisition was held before John of Ralegh, J.; what action the king took is not stated. There was much opposition to giving the borough more freedom than it already had, especially by those who had sukes and those who had the right to hold fairs (C.P.R., a. 1344, p. 290),

${ }^{2}$ Matthews, Cardiff Records, i, p. I 2, ante I 147. Both boroughs were chartered by the Earl of Gloucester. The customs were not Bretollian.

3 Tait, Mediaeval Manchester, p. 67. Their charters allow that a "burgensis, si non habuerit heredem, legare poterit burgagium suum et catalla sua, cum moriatur, ubicunque ei placuerit, salvo tamen jure meo." See also Whitaker, Manchester, ii, p. 585 . In each borough bequest 'in religione' was forbidden: in Salford chief lords could not be devisees.

4 See p. 55 , note 6 .

5 It must not be thought that all baronially or episcopally chartered boroughs were in the ignorant class. See, for instance, Congleton and Chard. 
twelfth instead of the thirteenth century it is very likely that devise would not have been mentioned at all. Such is the custom, or lack of custom, in regard to devise in the boroughs created by charters based on Norman models. It is, however, the borough which has grown which makes or unmakes a custom; the borough which is created merely reflects it. In the case of the little towns last dealt with the reflection is that of a somewhat ancient light from over the sea. ${ }^{1}$

From these unimportant and un-English towns turn we now to East Anglia, a region whose attitude toward devise is one of conservatism but not of ignorance. At Norwich, though inheritance might be sold, it might not be devised. ${ }^{2}$ It seems that entailed estates, with reversion, were quite common in Norwich and other East Anglian towns, ${ }^{3}$ and that the holders of such were not unwilling to treat reversion as remainder. ${ }^{4}$ There are many sections in the Norwich customal devoted to devise; most of them refer to such conditions as the wife's right to devise realty in presence or absence of heirs, entailed estates, possible heirs, and other conditions of the same sort. These are in the main matters of procedure, and do not affect the point at issue. ${ }^{5}$

At Ipswich all who had tenements ' of their several purchases' might devise them; therefore by implication inheritance was undevisable, ${ }^{6}$ a restriction which was still in force in the middle

1 On the other hand a few boroughs created in the same period as the Bretollian towns reflect the bright light from Bristol and Dublin. See Waterford, Limerick, and others.

${ }^{2}$ II udson and Tingey, Records of Worwich, i, p. ${ }_{55}$ (customal): " the acquirer may freely in his testament devise. . . the tenement acquired by him "; but "a tenement descending hereditarily to any one... or that ought to revert hereditarily cannot be devised."

a See below, Ipswich and Yarmouth.

4 The customals of these boroughs lose much space in forbidding devisces to alienate such estates; there must have been a reason to evoke these clauses.

5 In 1310 the finding of an inquisition ad quod damnum (see Stanley ". Mayor of Norwich, ete., f. 24) was that "all the tenants of that messuage from time whereof memory is not have . . . bequeathed [it] at their pleasure," and that this was the common custom of the city. It was not the custom of the city unless the messuage were one of purchatice which had never been allowed to slip back into inheritance.

${ }^{6}$ Le Domestay de (iippeiiyz. p. 7I. This Doom Book, from which Bacon took the customs for his history of Ipswich, was compilet soon after I 290, when, the old Doom Book having been stolen, a committee of 24 burgesses 'declared the ancient 
of the fourteenth century, judging from a suit-at-law in the borough court concerning a devise of inheritance. ${ }^{1}$ The plaintiff's legal remedy in such a case was by plea of abatement, which must be entered within forty days. ${ }^{2}$ At Yarmouth tenements 'in fee-simple' were devisable. ${ }^{3}$ It is somewhat uncertain how the Yarmouth burgesses used the term fee-simple, if indeed they used it at all. ${ }^{4}$ Giving the term its proper and legal meaning he who may not devise nor sell his inheritance has an estate therein but for term of life, and not in fee-simple. It appears, therefore, that an inheritance was undevisable at Yarmouth as its holder did not have therein an estate in feesimple. ${ }^{5}$ Colchester, too, was another East Anglian borough of restricted devise. ${ }^{6}$ At Newcastle lands of purchase only might be bequeathed. ${ }^{7}$

customs.' They much resemble the Norwich customs in respect to minor matters, such as the prohibition of devise of tenements already devised with reversion, and so on.

1 Bacon, Annalls of Ipswiche, p. 69, a. I34I. Tenements having been bequeathed by A. Davy to court came R. Davy, "the brother and heire of the Testator " and counterpleaded the granting of administration on the ground that the tenements "were of the Testators inheritance and that by the custome of the Towne noe man can, by his last will and testament, devise his inheritance or any part thereof."

2 Ibid., p. 25 (customal, cap. I8).

3 Swinden, I'armouth, p. I 58 .

${ }^{4}$ In his comments on burgage tenure Littleton says "if a man deviseth such tenements" (Littleton was dealing with entails, certain conditions being unfulfilled) "to another by his testament ... and dieth, and the devisee enter, he hath a fee-simple": conditions fulfilled, the devisee had an estate but for term of life (Coke, Commentary upon Littleton, sec. 586). See also Swinden, Iarmouth, p. 159 .

${ }^{5}$ As late as 1362 a devisor of a tenement stated distinctly that it was his purchase (Swinden, Yarmouth, p. 806, note).

6 Cromwell, Colchester, ii, p. 260; Morant, Colchester, p. 88.

7 The interpretation of the Newcastle custom presents the same difficulty as that of York. While York makes a specious case for freedom and must be given the decision, Newcastle is more ingenuous. Its historian (Brand, Newcastle, ii, p. I43, note, a. I 276) draws no line between inheritance and purchase: "Burgenses Novi Castri super Tynam possint legare terras et tenementa sua tanquam catalla cui voluerint." Before this, however, the charter of I 2 I 7 had granted that " rectum eis [i.e., tenementis] teneatur secundum consuetudinem . . . Winton" " (ibid., ii, p. 136 , note $\mathrm{x}$ ). Though Winchester was probably a city of restricted devise, this is not quite conclusive evidence; affiliation of customs was very elastic 
Shrewsbury ${ }^{1}$ and Rhuddlan have been claimed as boroughs with Norman customs. In each, therefore, devise should be unknown. Purchase, however, was devisable in both boroughs. ${ }^{2}$ Bury Saint Edmunds had a custom peculiar to itself: purchase was devisable and half of inheritance as well; ${ }^{3}$ the customal even provided a remedy at law for defrauded heirs. ${ }^{4}$ This charter (1327) was virtually drawn up by the burgesses and the limitation on the devise of inheritance was placed there by themselves, no doubt to prevent a dying sinner from saving his soul at his heir's expense. More monachorum, the saintly guardians of St. Edmund's shrine preferred gifts, naturally largest when extracted to the sound of the passing bell. But for the fear of death many a monk might have been an honest worker. The custom at Bury Saint Edmunds is peculiar in another way; inheritance might not be sold, though half of it might be devised. As far as our evidence goes, this contemporaneousness of restricted sale and free devise existed in no other borough in England.

in England. See Gross, "Affiliation of Mediaeval Boroughs" (Antiqnary, i 885, pp. $142^{2-1} 47,253^{-259}$; reprinted, with additions, in the same author's The Gild Merchant (1890), i, pp. 241-281). There is, however, corroboration elsewhere; "Newcastle ... Every burgess accorling to the customs of the borough can bequeath lands . . . which he has of his own purchase to whomsoever he will" (C. I. H., ii, P. 94, 4 Ed. I). See also C. P. R., a. I276, pp. 140 and 1 19: "that . . a according to a custom of Newcastle . . a burgess thereof should be able to clevise as his chattels . . lands . . . which he had by purchase."

1 Matox, Firma Burgi, p. 128, note q, 20 Ed. I: L. "dicit etiam quod licitum est secundum consuetudinem civitatis Salopesbiriae . . tenementa perquisita legare." For the same case see Iforwood and Pike, Jear Books, Nichclmas term, I202, Pf). 262-260. A writ of $\mathrm{N}$. 1). was procured, the city apparently having no Assize of liresh Force. The jury" answered as above in the royal court.

2 For Rhudelan see Parliamentury Papers, 1835 , xxvi, p. 2838 : "Liceat unicuique civi . . tenementat sua quae silsi adquesierat . . in testamento suo . . . legare." This provision was sald to be taken from the llereford custom. Probably at that time purchase alone might be bequeathed in IIereford.

3 Arnold, Memorials of St. Lidmund's Abbey, iii, p. 300 : "we" (i. c., the abbot) “. . grant trat no man have power to devise more than the half of his inheritance." "We . . grant that every one may have power to dispose entircly by will of tenements which he shall have by purchase."

"lbid., iii, 1) 31r. "The "next heir comes before the Alderman and the burgesses on the second day after proclamation . . . show his title," etc, and the court decides whether it be good. 
At Dunwich purchase was devisable. ${ }^{1}$ The avidity with which Henry III pursued the will o' the wisp of burghal escheat enables us to place Southampton among the boroughs where purchase only might be willed. ${ }^{2}$ Tenements in that borough which a burgess had bought he devised without gainsay; he made no effort to devise his other tenements, to which there were heirs who claimed them. Portsmouth was a borough of restriction; ${ }^{3}$ Weymouth was very probably in the same class. ${ }^{4}$

In a few of these boroughs there were small restrictions, some of which are hard to explain, in respect to freedom of devise. Thus at London, though devise was so free that the mere fact that tenements were situated therein sufficed to prove their devisability, ${ }^{\mathbf{5}}$ there was one limitation which lasted till the close of the seventeenth century, - a husband might not devise tenements to his wife for a longer term than her life. ${ }^{6}$ At Dublin, ${ }^{7}$ and probably in its daughter towns, it is said that a bequest made by a citizen while the heir was abroad was invalid. In addition there were provisions to prevent unjust disherison of heirs, though how the citizens put these provisions into practice or reconciled them with their custom of devise is not easy to say. ${ }^{8}$

1 Hardy, Rotuli Chartarum, p. 21 I.

${ }^{2}$ C. I. M., i, p. I 35,45 Henry III. The inquest finding in the case is long and complicated, for the deceased burgess seems to have been a man of great possessions, having " divers tenements held of divers lords." To these tenements he had " heirs who claim them." In addition he was chief lord of several shops which he had bought, "which the merchants of Due and Ipri [Douai and Ypres] held of him, which he had by purchase . . . and bequeathed . . . and two shops held of the said bishop [of Winchester] which he had by similar purchase."

${ }^{3}$ East, Records of Portsmouth, pp. 5, 6.

${ }^{4}$ Moule, Charters of Weymouth and Melcombe Regis, p. I6: the charter granted the same degree of mobility as at Southampton and Portsmouth. The Melcombe Regis custom probably followed that of Weymouth.

${ }^{5}$ C. I. M., ii, p. 362, I4 Ed. I: R. held tenements in London, "so that he could bequeath them to whomsoever he would."

"Sharpe, Calendar of Wills, i, p. xxxviii. The author instances several cases in each of which a widow chose to forego probate and take possession of tenements devised to her in defiance of the custom rather than risk a judgment in the Hustings.

7 Gilbert, Records of Dublin, i, p. 229.

8 See Gilbert, Historical and Municipal Documents of Ireland, II72-I 320, pp. 262263. Disherison in anger was forbidden. All this is from an abstract of the "Chain- 
In such places as London and Oxford it is hard to know when restrictions on devise had been abolished. It seems that freedom from restriction was the result of a progressive movement; that in some boroughs its beginning was so early that it was received, when existing records begin, as a custom descending from beyond the time of legal memory; that it was obtained by charter in a few places; and that in others it overcame the older custom, as the change in the collective mind of the burgesses changed the burghal land law. ${ }^{1}$ At times there were attempts at defiance ${ }^{2}$ or evasion of the custom which forbade devise of inheritance, but in such cases the heir had only to lay his claims and title before the bailiffs and burgesses in the borough court; if it did not right him the royal courts were open.

The most important economic question in connection with restricted devise is the extent to which it affected the mobility of urban tenements. In the boroughs where restriction existed an inherited messuage could not legally be bequeathed, but it could be divided, and in some cases might be sold. How land of inheritance might become land of purchase in the boroughs where both sale and devise were fettered has been previously explained; ${ }^{3}$ once transformed it would be the holder's own fault or intention if it should slip back into land of inheritance, unless he dwelt in one of those benighted boroughs which knew no devise or sale without consent. For, though it is doubtful whether a devise of land of purchase in favor of one who would inherit in the absence of a will was regarded by the courts as of any legal effect, ${ }^{4}$ a purchased tenement might nearly

Book." There would be no need of such provisions where inheritance was undevisable; 'purchase' had no heir any more than a living man has an heir.

At Waterford it is said (Bateson, Borough Customs, ii, p. 96) that an heir may forbid anyone to buy, and afterward may recover, if his father has disinherited him in anger. How was the anger to be proved, and what had the courts to say about motive rather than fact at this period? "The thought of man shall not be tried," etc.

1 In this respect and connection the burgess of the thirteenth century' seems less conservative than the burgess of the fifteenth.

2 As at Bristol in 9 El. I (Roberts, Cal. Genealogicum, i, p. 313).

3 See p. 125.

4 See Horwood and Pike, lear Books, a. 1292, pp. 262, 206. A son had bought his father's share of a messuage in Shrewsbury, a borough where sale or devise 
always be sold to one not an heir. In boroughs where sale was free, as Norwich, and in almost any borough through sale in need, one who wished to prevent descent of real property in accordance with the burghal law of intestacy might sell it and make sure. ${ }^{1}$ Probably, however, neither this nor any other plan to avoid restriction was often followed in mediaeval days. The burgess of that period usually preferred to see the son in the father's place, living in the messuage once his, taking his vacant place in the gildhall, and his seat within the four benches; while the law of devise in the older boroughs was only what law is at any time and in any place, the public opinion of a great majority, and subject, therefore, to amendment and change.

And when there came a time in which limitation of devise was felt to be a burden, it is unlikely that the custom would long be allowed to block the way, especially in the commercial towns; usurpation, collusion, now and again a royal grant, ${ }^{2}$ in the older and important boroughs change in the customal, and men forgot that certain sorts of tenements were once not devisable. This change in respect to free devise seems to have been very gradual. Oftentimes, as at Dublin and Bristol, it was never formally enacted as a part of the ancient customal, or else its registration has been lost. In these cases such change as there was is often shown by the records of the courts. Despite its restrictions, devise of land presents the aspect seen by Bracton

of inheritance was not allowed. This share would have been his inheritance at his father's death. The son devised the messuage: it was decided by the court, that this did not keep the tenement one of purchase. Yet at Kingsthorpe, which, though not a borough, was allowed to imitate many of the customs of burgage tenure, possibly because it was part of the ancient demesne, one might devise a messuage which one had by gift, sale, or bequest, but not a tenement of inheritance (Glover, Kingsthorpiana, p. 4r).

1 Some of the quick and circuitous sales at Norwich may have had this as their object. See Hudson and Tingey, Records of Norwich, i, p. 233, a. 1287. A. granted a messuage to B. on July 29, B. granted it to C. on August 4 , C. granted it to A. on August 9.

2 Sometimes devise was petitioned for. In 1298 the men of Kingston-upon-Hull and Ravenser prayed "qe le Rei voile faire le dite Ville Fraunk Burg . . . et qil peussent leur Tenemenz en la dite Vile deviser en leur Lit mortel " (Thompson, Holderness, p. 147). There is nothing to show that their request was granted. 
as the leading feature of English burgage tenure, especially in the contrast between the mobility which it secured and the feudal rigidity beyond the borough bounds, where 'God alone and not man could make an heir.' 1

\section{The Rights of the Femme Covert}

The rights which a wife had in her own and her husband's tenements were fairly uniform throughout the English boroughs. In one particular the uniformity was absolute; the wife had the right to give or to withhold her consent to any alienation made by her husband of a messuage she brought at marriage. If the husband alienated such without her consent, or even with it, the transfer was void in the first case, and in the second she could recover by plea of duress, unless this consent were given out of his presence and in that of the bailiffs. The husband might, as a rule, alienate without let a tenement which he held before marriage, subject only to the custom of the borough as regards alienation. If he acquired tenements after marriage his wife must consent to their alienation, though not always in the public way in which she assented to the alienation of a tenement of her own. This feature, or rather fiction, of the burghal land law arose from the idea that the messuages had been jointly acquired

1 In connection with devise some significance has been attached by various writers to the expression 'tanquam catalla,' as if the messuage's being sold or devised arose out of its being first thought of as a chattel and therefore satealsle or devisalble (see, for instance, Tait, Mediuezal Manchester, 1). 68: "which, being "comparable to chattels",). A messuage cannot be compared with a chattel until it is first sold. The linglish burgesses seldom used the phrasc; when they did it was commonly connected with devise and not sale. In addition, whatever they said they did not devise their tenements 'tanquam catalla,' the custom as regards devise of lands and that in respect to devise of chat tels were wholly different. In flanders and at times in (iermany there seems to be good reason for regarding the bouse as a chattel, it and the land under it often being subject to different customs in respect to sale. This was never the case in England, land and lomse went together in freeclom and in restriction, each was a burgage tenement and both were a burgage tenement (see p. 92).

See, for examples, most of which are 'et sua catalla' or merely ' 't catalla' and not 'tanquam catalla,' Brand. Teticustle, ii, p. 1 $\$ 3$. note; Widdrington, Analecta Eboracensia, p. 59; Cinper, Cambridge, 1). 74; Stevenson, Records of Notlingham, i, p. 230; Parliamentary P'apers, 1835 , xxvi, p. 2838 (Rhuddlan), and a few others. 
and so must be jointly sold, ${ }^{1}$ a feature common to urban tenure in northern and western Europe. ${ }^{2}$

At Norwich a wife's consent was necessary for the devise of a messuage acquired by her husband after marriage. ${ }^{3}$ As a rule a husband might devise tenements to his wife, subject, of course, to the custom in respect to devise for any particular borough, ${ }^{4}$ though in London such a devise was limited to the term of the devisee's life, ${ }^{5}$ and in like manner a wife might will her own realty to her husband. ${ }^{6}$ At Norwich, as in most boroughs, a wife might devise the messuages she held at marriage ' to whomsoever it shall please her away from her husband,' if no child had been born from their marriage. Otherwise she might still devise them, but her husband was tenant for life by the courtesy of England. ${ }^{7}$ At Ipswich the husband's consent was necessary to a devise by a wife, and she must not disinherit her heirs. ${ }^{8}$ It seems that in most boroughs the law of restriction,

1 Conveyances of such tenements usually follow the formula: 'A. and his wife B. give, grant, . . . to X. and his wife Z. (or to X. alone),' etc. See Hudson and Tingey, Records of Norwich, i, pp. ${ }_{15}^{6-157}$ and deeds everywhere: the "man and his wife have together and conjointly acquired." The necessity of the wife's consent to alienation of realty sometimes led to special inducements being offered her. Temp. Ed. I a 'stall' in Bridgwater changed hands for 20 .: in addition the grantee gave the grantor's wife a pig worth 2 s., " to have her consent beforehand" (H. M. C., Rep., 3, p. 31 I). At Wells c. I 200 a messuage was granted for 50 . praemanibus and a yearly rent of Ios., also $6 \mathrm{~d}$. to each of the grantor's sons and to his wife a "golden fermail" (ibid., p. 360), which was, methinks, some sort of buckle. In Clifton (Dartmouth) temp. Henry III, a tenement was conveyed by Richard de Sege to Martin Fake, for 4 marks beforehand and an annual rent of 2 s. Martin contributed also to the grantor's family: to his wife 2s., to a daughter Is., to two other daughters $6 \mathrm{~d}$. each, to one son a pair of boots, and to another a 'tunica' (ibid., 5, p. 600). These payments to possible heirs probably aimed at forestalling the exercise of the kin's retrait. In another transfer the grantee abjured the lure of money and fermails and paid a barrel of wine praemanibus. The subsequent proceedings are not recorded.

2 See Arnold, Geschichte des Eigentums in den deutschen Städten, p. 166; Génestal, La Tenure en Bourgage, pp. 76 et seq.

3 Hudson and Tingey, Records of Norwich, i, pp. I $_{5}^{6-I_{5} 7}$.

4 See Widdrington, Analecta Eboracensia, p. 67; Gilbert, Records of Dublin, i, pp. $489-49 \circ, a$. 1483 , and others.

5 Sharpe, Calendar of Wills, i, p. xxxviii.

${ }^{6}$ H. M. C., Rep., 9, pt. I, p. I7 I; C. A. D., i, p. 68 (Reading).

7 Hudson and Tingey, Records of Norwich, i, p. 156.

${ }^{8}$ Bacon, Annalls of I pswiche, pp. I7, 27, a. 1290. 
where it existed, in respect to sale and devise of realty was relaxed somewhat for tenements which a wife brought at marriage. The chief peculiarity, however, of the burghal land law in respect to such tenements, and the difference between it and the common land law, was the idea of joint acquisition and joint alienation. ${ }^{1}$

\section{Mortgage}

In most boroughs the right to mortgage was subject to the same restrictions, or enjoyed the same freedom, as the right to sell, for the mediaeval mortgage was itself a sale, in form at least, whatever it might be in fact. As a result the customals of the older boroughs seldom or never used the term at all: there was no need to duplicate already existing clauses in respect to sale, even when the grant was only for a period of years or until a certain sum should be paid the grantee. In the boroughs by charter, however, the right to mortgage a messuage was often expressly permitted. Such was the case at Tewkesbury ${ }^{2}$ and probably at Cardiff. The charters of the boroughs of Ireland usually recognized the right to 'pledge tenements '; ${ }^{3}$ the char-

1 Dower was not peculiar to burgage tenure. It was, however, somewhat variable in the boroughs, usually a half or a third (depending on the absence or presence of children) of the husband's messuages, or their revenue, for life. Some of the customals allowed the widow her husband's chief house as her free-bench (frank-bank), if he had more than one messuage (Bacon, Innalls of I psuiche, p. 34). Those who had no right of frank-bank were entitled to the widow's quarantine. Neither waste nor alienation was allowed; a widow who defied the law was liable to lose her dower and to be cast in damages as well (Bacon, Amulls, p. 9). At some boroughs a widow who remarried lost her dower and frank-bank ('Tait, Mediaczal .1/anchester, p. 70). See for dower (illbert, Records of Dublin, i, p. 97; Simpson, Derby, i, p. 4t; Stevenson, Records of Nottinghtm, pl. 1 25, 169; Markham, Liber Custumarum, p. 20; IIudson and Tingey, Records of Norutich, i, pp. 290-297; and almost any of the better class of borough histories.

lower was compulsory where devise of inheritance was not permissible and when a burgess neglected to make a will in a borough of free devise. Bracton says (De Legihus, i, p. 164, De dote uxoris bastardi): "Sed de dute mulieris quid fiet in hoc casu? ex quo warrantum non habet de dote sua, cum nec appareat haces nee assignatus, nec etiam legatarius, si forte legatum fucrit, sicut in bur. gagiis; mulier in omnilms istis casilus dotem obtincbit." From an examination of many testaments in towns of free devise it seems plain that dower was conpulsory only in connection with intestacy.

2 Bennctt, Takkesbury, p. 321 .

3 See (iale, Corporate System of Ireland, app., pp. xii, xxiii et pass.: "vendere vel insadiare" etc. 
ters to the burgesses of Chard ${ }^{1}$ and Altringham ${ }^{2}$ had like clauses. ${ }^{3}$ At times mortgaging without the consent of the lord of the borough was forbidden for special cases. ${ }^{4}$ The charter of 1227 to the burgesses of Salisbury forbade them to mortgage their messuages without the consent of the bishop of Salisbury; ${ }^{5}$ the charter of ${ }^{3} 305$ limited this interference to cases where religiosi were the mortgagees. ${ }^{6}$

Though the form of the ordinary borough mortgage was that of a grant or conveyance with a clause reserving the right of redemption, at times the word mortgage was used openly. ${ }^{7}$ The date on which payment must be made commonly appeared in the deed $;^{8}$ this payment was usually a lump sum, but might be made by instalments. ${ }^{9}$ That the grantor commonly continued to live in the mortgaged messuage, though no longer its owner (or lowest holder); that the price to be repaid was larger than the loan by enough to allow interest and so evade the canon law; that he who defaulted in his payment might be ejected; that the tenement passed wholly to the mortgagee regardless

1 C.P.R., a. 1286, p. 216.

2 Parliamentary Papers, 1835 , xxvi, p. 2838.

${ }^{3}$ Grants sometimes contain permission to mortgage, as at Kenfig, c. 1 270-79, "cuicunque . . . invadiare . . . voluerit" (Clark, Cartae Glamorg., iii, p. 530).

4 This could be the case only in trifling towns, commonly with ecclesiastical lords.

${ }^{5}$ Jones and Macray, Charters and Documents of Salisbury, pp. I76-177. This charter was an adjustment by the king of the disputes between the bishop and his burgesses. Lay lords and their burgesses disagreed only at times; ecclesiastical lords were nearly always at strife with their boroughs, even with boroughs in which they had nothing but sokes. Vide Norwich.

${ }^{6}$ Hoare, History of Modern Wiltshire, vi, p. 738. At Kingsthorpe no one was permitted to mortgage his tenement for more than three years on pain of forfeiture thereof to the town (Glover, Kingsthorpiana, p. 92).

7 See Baines, Liverpool, i, p. 145. "Be it known . . that I . . have given ... and by this deed confirmed in mortgage" half a messuage, "to be held " till $£_{I} 7$ " are paid." No limit in time was set for payment: if the mortgagee did not take possession in due season he might as well consider his $£_{I 7}$ a gift.

8 As at Southampton, I6 Rich. II. A 'deed of sale' was made, the seller reserving the right of redemption on payment of 16 marks on or before a fixed date (H. M. C., Rep., II, app., pt. 3, p. 73).

${ }^{9}$ H. M. C., Rep., 5, p. 514, 5 Henry V. "If the said G. C., or any one in his name, shall pay to them [i.e., the grantees] . . . Ios. and continued sums of Ios., amounting in all to a sum of $£_{7}$ ros., then the said deed shall be held as null." 
of its excess value over that of the loan, - for there was no equity of redemption in that period, - are accompaniments which need no proof. The mortgagee might sell the tenement, deduct his debt, and pay the 'hyperocha' to the mortgagor. It would be rating human nature too high to think that he often did so. ${ }^{1}$

\section{Accumulation of Burgages}

From Waterford in 574 came a complaint that there was but little land for sale in the borough, the bulk of the tenements being held by the church, and other outsiders, who preferred to lease." Most boroughs might make the same complaint, for by that time outside holdership was the rule for at least the 'original' burgage tenements. It is apparent that the Waterford burgesses' objection was economic, for the date is too early for foreign ownership of burgages to have much political effect, discussion of which is irrelevant to our subject and beyond our period. The chief sources for this matter are Calendars of Wills and of Inquisitions post mortem, which afford a vast number of illustrations.

For instance, at Southampton a burgess named Nicholas Hachard ${ }^{3}$ was a notable accumulator. He was surpassed, however, by John Ouhtred of Scarborough, who held more than ninety messuages, most of them directly of the king. 'The bulk of these tenements came to him from his uncle. Robert of Scarborough, and passed from him to his daughter and sole and minor heir, who, on account of her holding in the foreign, became a ward under the feudal tenure and was married into

1 Ior mortgage see 1)r. II. R. Hazeltine, Die Geschichte des englischen l'fondrechts (Breslau, 1907), especially p. 291; also T. E. Scrutton, The Influence of the Roman Law on the Law of England (Cambridge, 1885), pp. 157 et pass.

${ }^{2}$ II. M. C., Rep., 10, app., pt. 5, p. 333.

${ }^{3}$ C. I. $1 /, \mathrm{i}, \mathrm{P}, \mathrm{1} 35$. He had I 4 shops, land outside the wall, and many tenements within. 45 Henry III.

- See Brown, Horkshire Inquisitions, iii, p. 91-93, a. 1298. IIis capital messuage was worth by the year fos.; he held also 8 messuages occupied by 'free tenants.' that is, at fee-farm; to messuages renting at is. to 2.4s.; 40 messuages occupied by tenants at will, rents of the same $18 \mathrm{~d}$. to ros., etc. For all these he paid $27 \mathrm{~s}$. to the Firmal Burgi; his rents were $\mathfrak{E}_{40}$ and more. He also held land in the honor of Albemarle, the manor of Gow thorpe, etc., by knight service. 
a county family. Thereafter the holdership would probably continue to be aristocratic. In London the bishop of Ely held, though not as bishop, many tenements and rents of burgess lords. ${ }^{1}$ In Southampton widows and dukes appear as accumulators. $^{2}$ Bristol was a city of large accumulations; ${ }^{3}$ even viscounts and queens had tenements there. ${ }^{4}$ Perhaps the greatest holder of burgage tenements in the realm was W. Canyngs, or Cannings, 'merchant and burgess' of Bristol. ${ }^{5}$

Multiplication of such records would be mere and easy repetition, for every borough with any pretension to commerce shows this condition to a greater or lesser extent. As a result of its praiseworthy and unceasing labor in the care of souls, especially departing souls, in the first half of the sixteenth century out of

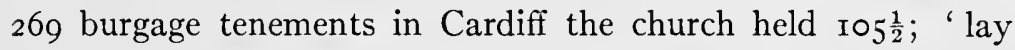
burgage tenants' held but seventy-five tenements, the corporation and clerical lords (seculars holding as individuals) having the rest. ${ }^{6}$ This proportion, about two-fifths, is somewhat higher than the usual amount of urban realty in the dead hand; perhaps a third would be nearer the average. But busy friars and weary monks were soon to rest from their toil in the vineyard

${ }^{1}$ C. $I$. $M$., ii, p. 478, I 8 Ed. I. He held in 'Holeburn' (sic) " a tenement upon which his hall .. . [is] built," service Ios. 4 d.; 4 tenements at $2 \mathrm{~s}$. to $6 \mathrm{~s}$; ; a messuage whose rent was a rose; another by service of $14 \mathrm{~d}$. to one lord and $14 \mathrm{~s}$. to a second; and many other messuages, besides I03s. $3 \mathrm{~d}$. of rent.

${ }^{2}$ H. M. C., Rep., I I, app., pt. 3, p. 85 , I Ed. IV. One widow granted I3 messuages. The Duke of Exeter held others (ibid., p. 86).

${ }^{3}$ Bickley, Little Red Book of Bristol, i, p. 94, a. 1361. One burgess complains that she has been disseized of 4 messuages, 13 shops, $12 \frac{1}{2}$ acres of land, and 20 s. of rent. In 1453 an inquisition shows a burgess to have held ${ }_{5}$ tenements, in four of which were 25 shops; I 2 of the tenements he held from a 'gentleman' (ibid., ii, p. I96).

${ }_{4}^{4}$ See Little Red Book, i, p. 126 for the queen's tenements.

See $C$. $I$. M., Henry VII, i, p. 337. Viscount Lisle held 84 messuages, I9 acres of land, the advowson of a church, etc., in Bristol, all worth $£_{3}$ a year. He held of the mayor and community. In Worcester he held the "fourth part of 24 burgages" (ibid., p. 339); and he held many messuages in other boroughs.

Joan Barre, a widow, had ro messuages in Monmouth held of the prior of Monmouth, and to in Chepstow held of the Earl of Huntingdon (ibid., p. 47).

5 See Bickley, Calendar of Deeds, chiefly Relating to Bristol, pp. vii f.; also Wadley, Abstracts of Wills.

6 Matthews, Cardiff Records, i, p. 103, a. 1542-43. 
of the borough and the Lord; the harvest was now ripe for the Tudor sickle, the church had sown, the nobles and the gentry reaped; the political Reformation might have been quite different had the church not lost its burgages.

Accumulators, however, were not always ' foreigners.' Ouhtred of Scarborough, Dunning of Cambridge, ${ }^{1}$ Cannings of Bristol, kings among accumulators, these men were burgesses. Long before the Reformation, however, the knight and the noble were accumulators too, though seldom or never indwellers. The records, especially those in the Calendars of Patent Rolls, show that all through the middle ages burghal realty was passing through the king's hand, ${ }^{2}$ usually to those of nobles and gentlemen. This was the source of much of the aristocratic holdership and accumulation of the fourteenth and fifteenth centuries. Accumulation began in some boroughs in the thirteenth and possibly in the twelfth century. This matter has been ably and inimitably dealt with at Cambridge, where its development was rather precocious, ${ }^{3}$ there being about twice as many houses as burgesses when the Hundred Rolls were compiled. Early in the twelfth century the number of burgesses in Winchester was nearly equal to the number of houses. ${ }^{4}$

The consequences of this concentration of holdings in a few hands depended during the greater part of our period on the relative position of the accumulator upon the tenurial ladder, for there might be many holders before the borough lord was reached. To a less extent they depended on whether the accumulator was the church, a non-inhabitant aristocrat, or a burgess. If, for instance. in any one of these three cases the accumulator were the lowest holder of several burgages, his (or its) social

1 See Matland, Toanship and Borough. p. 107, C. 1219 ; R. II., ii, Pp. $35^{t}$ et seq.

2 See Furfeiture, p. 33.

3 See Maitland, Township and Borough, pp. 66, 60. " There were no patrician land-owners" indwelling, though "great families" outside were mesne lords. "Some wealthy burgesses own land lin the fields]; others own none." "Often a burgess is . . . lowest freeholder of 3 or 4 houses."

4 I). B., iv, liber Winton', fi. $1-11$, t. 1103-15. Conditions were much the same as they had been 'T. R. E. Each burgess had commonly one 'mansion' or 'domus,' which alnowt always paid landgable. The burgess therefore had no ford but the king. This excepts the bishop of Winchester's tenements. 
and economic influence would be great, unless his leases had long terms to run. ${ }^{1}$ If, on the contrary, the lord occupied any other place in the tenurial scale than that of lowest holder he had no influence at all; he was merely a man with a rent charge. Toward the clergy, and especially toward the regulars, the burgesses were commonly hostile. ${ }^{2}$ When the neighboring knight or noble was lowest holder, either his tenements had been granted him by the king or he was investing surplus wealth. $\mathrm{He}$ was, however, not always on hand to enforce his rights. On the other hand, to the burgess accumulator his tenements were his capital, though not necessarily his whole capital, much depending on the amount of commerce in any particular borough; in addition he was on the spot to look after his investments. ${ }^{3}$

Though the church was a great holder of urban realty in the mediaeval period, the greatest lowest holders, who alone might make profit of the burgages, were commonly burgesses. Toward the close of the middle ages the freeholder was the exception, the lease holder or termor was the rule. ${ }^{4}$ In the early modern period the church's burghal holdings, like most clerically owned realty, passed to the nobility and gentry, and noble and gentle ownership became more and more common as the political importance of the borough (not of the burgesses, however;

1 His political influence would be great in the modern period when it was an object to become or to control the parliamentary representative. This was of small importance in the middle ages.

${ }^{2}$ See Charles Gross, "Mortmain in Mediaeval Boroughs," in American Historical Review', July, I907, pp. 733-742. This hostility was both personal and economic. Tenements in the dead hand often escaped all burghal dues and imposts. Seculars' tenements, however, were held in the usual way, and the seculars themselves (priests at least) were often excellent citizens.

3 Discussion of the investment of capital in boroughs by patrician land-owners who took their interest as rent-charges, or who, if lowest holders, acted as landlords, would lead us too far from the tenure. The extent to which burghal realty might pass into the hands of neighboring land-owners as a result of marriages with burgesses' heiresses was probably small during the mediaeval period; its discussion also is outside our province.

4 The records of transfers of realty in the boroughs show how property passed into the dead hand. See Brand, Newcastle, pp. 208-219 et pass.; Bacon, Annalls of Ipswiche, p. 53 et pass.; Swinden, Yarmouth, pp. 804, 8I 5 et pass.; and others. For the king as holder (not as lord of the borough) see the Extracta or Estreats . in Rotulorum Originalium in Curia Scaccarii Abbreviatio (1805-10), 2 vols. (R. C.). 
barring a few instances they were only pawns) increased, till very modern times. ${ }^{1}$

In short, it appears that tenurial economic conditions in the English boroughs of the later middle ages were not very different from what they are today, except that they were likely to be much more complicated, ${ }^{2}$ for the accumulator was obliged to take his chance, not as ultimate lord nor as chief lord, but simply wherever he could step in, the lower in the tenurial scale the better. $^{3}$ Commonly the tenure was a tangle; and it is easy to see how this tangle, which necessarily caused difficulty in tracing the line of holders of any particular tenement, must eventually clarify the idea of ownership.

The most important topic of this chapter is the law of sale and devise. When the towns of free or restricted sale and devise are arranged in their respective groups, ${ }^{4}$ it will be seen that, while the boroughs where sale was limited by the kin's preëmption outnumber those where sale was free, those where devise was free were not greatly outnumbered by the boroughs where devise was unknown or limited to purchase. In addition, boroughs of free devise appear among those of restricted sale, an apparent contradiction due to later change in the burghal land law." The remark of an eminent scholar that "there were boroughs perhaps more numerous than Professor Maitland supposes where the power of sale continued subject to limitations " (i.e., kin's retrait), ${ }^{6}$ is abundantly justified by the evidence. In Ireland only Dublin and its four followers were free from retrait lignager, and, though the immobility of the other Irish boroughs was due to their foreign customs, even London in

1 One must insert ' landlordly' in the place of ' noble and gentle' today.

2 For instance the bishop of Ely held, in his private capacity, many tenements in London; for some he was lowest holder, the lords being burgesses and one of them a carpenter. See C.I. M., ii, p. 478,18 lid. I.

3 When one became a mesne lord it was usually by accident. Excepting elimination of lower lords such a place was valueless.

- See pp. $183-18$.

- See p. 184 . Altringham and Bridgnorth appear in the ranks of the boroughs of free devise. They must have been eleventh hour recruits, the latter especially.

6 Tait, Mediaeval Manchester, p. 67. 
the eleventh century showed a trace of the old Germanic kin's retrait.

Though sale in need and other legal fictions opened a gap in the wall of restriction, the common usage is seen in the reflection of the common mind, the customary land law of the borough. The boroughs of East Anglia and the southeastern coast seem most consistent in this respect, especially in regard to devise. For the rest of the boroughs these impediments on mobility, at least in respect to sale, practically vanished by the close of the middle ages: the ice of restriction had been thawed by the sun of commerce. ${ }^{1}$

1 This was not necessarily foreign commerce; Cambridge for instance had but little of that. Perhaps French influence, which affected the Cinque Ports more or less, accounts for their backwardness in the matter of mobility. Yet on the other hand the East Anglian towns, almost as conservative as the Cinque Ports, traded much with Flemish cities, where sale of realty was unhampered. 


\section{CHAP'TER IV}

\section{ACCOMPANIMENTS AND COMPARISONS}

\section{The Firma Burgi}

THE fee-farm rent, commonly called by the mediaeval burgess simply the farm of the borough or Firma Burgi, means the lump sum paid annually and in perpetuity by the burgesses to the borough lord in composition for the profits of burgage rents, courts, markets, mills, tolls, and other sources of ordinary revenue which the lord derived from the borough. As a rule only royal boroughs had this privilege, which was valued highly because it excluded the king's financial officers. A gift of the Firma Burgi has been considered by some to have exempted the burgesses from paying tallages, possibly because the annual Firma Burgi was so much greater than the annual services and profits for which it was a commutation; it did nothing of the sort. As a feature of burghal freedom it has been sometimes spoken of as if it conferred or carried with it other privileges, such as civic governmental and tenurial liberty, when, the final step of making a borough a county excepted, it was in fact the last favor which a borough could receive, a grant of the farm in fee presupposing the possession of all other burghal privileges, either as gifts by charter or as rights by custom and use.

In the case of a borough created by charter the place might have been erranted to the townsmen in fee-farm at the time it was chatered. As fatr as our evidence shows no such thing ever occurred.' The burgesses of such communities needed to adjust themselves to their new conditions before they were ready to decide how much they could afford to pay yearly and forever, or indeed whether they wished to pay anything, for the

\footnotetext{
It Bridpert (C. C. R.. i, P. 4.35, 4. 1253 ), the charfer stated that the town "shall in fulure be a free berough." and at the same tine granted the farm in fee to the bureseses, at an anmual increase of $40 \mathrm{~s}$. Bridport was a borough long before 1253.
} 
privilege of excluding the sheriff in his ordinary financial capacity. A grant of the Firma Burgi in fee nearly always increased the borough rates for years to come, while the lord of the town ${ }^{1}$ was commonly sufficiently far-sighted not to discount the future except at high interest. ${ }^{2}$ For a stationary farming borough a grant of the farm might be too great a burden: such towns seldom asked it. The older and important boroughs seldom rested until they got it. ${ }^{3}$

Lincoln affords an early instance of a grant of the farm in fee; in I 30 its citizens paid 200 marks of silver and four marks of gold to keep out the king's financial officials. ${ }^{4}$ Preston is said to have got its fee-farm about II $73 .{ }^{5}$ In 3 I Henry II the burgesses of Northampton rendered account of 200 marks "for having their town of the King in Capite." 6 Northampton's farm was paid to the sheriff of the county, and by him to the Exchequer, ${ }^{7}$ though most of the boroughs with this privilege accounted through their bailiffs in the Exchequer. Late in Henry II's reign the burgesses of Cambridge paid 300 marks of silver and one of gold to exclude the sheriff; the farm was not granted in fee till $1207 . .^{8}$ Even when it had been granted in perpetuity, the Firma Burgi might be 'seized into the king's hand' for some real or imaginary offence. On such occasions, however, the bailiffs as a rule still performed their ordinary financial duties, the royal keeper (custos) merely overseeing.

1 In practice this means the king's financial advisers.

${ }^{2} \mathrm{He}$ was usually willing to grant the farm to the citizens for a short term of years. This was the case at Cambridge from I 86 to 1207 . See Cooper, Cambridge, i, pp. 28,33 .

${ }^{3}$ At first sight it may seem as if some Joroughs of small importance, such as Pontefract (H. M. C., Rep., 8, p. 269, 5 Rich. I) and Farnham (Hall, Pipe Roll of the Bishopric of Winchester, p. 37, a. 1208-o9) had grants of the Firma Burgi; "Quum [praepositus] pacaverit domino [of Pontefract] firmam burgi ad festum sancti Michaelis." This is merely the farm, not a fee-farm. Every territorial unit in England had its farm.

${ }^{4}$ Stubbs, Constitutional History of England (library ed., Oxford, I880), i, p. 468.

5 Fishwick, Preston, p. I2.

${ }^{6}$ Markham and Cox, Records of Northampton, i, p. 21. This means only the fee-farm rent: Northampton was always a royal borough.

7 Ibid., ii, p. 209.

8 Cooper, Cambridge, i, pp. 28, 33. 
The suspension, which was looked on as temporary, might even be a financial loss to the Exchequer.

Nottingham seems to have had a grant of the farm before I $60 ;{ }^{1}$ Norwich claimed the privilege in 1 I 58 but did not get it, except for a brief time, till I 194 at the earliest. ${ }^{2}$ It is noteworthy that the boroughs of Ireland which were earliest farmed by their burgesses were Bristollian: Dublin, Limerick, ${ }^{3}$ and Cork. ${ }^{4}$ Newbury was at fee-farm in $1205,{ }^{5}$ Kingston in $1209,{ }^{6}$ Carlisle in $1221,{ }^{7}$ Derby in $1229,{ }^{8}$ Portsmouth in $1229,{ }^{9}$ Basingstoke tempore Henry III, ${ }^{10}$ Canterbury in $1234,{ }^{11}$ Scarborough in I $253,{ }^{12}$ Rochester in $\mathrm{I}_{2} 65,{ }^{13}$ and so on till we come to Woodstock, with its tiny fee-farm of four marks, in $1453,{ }^{14}$ and Plymouth, an abbatial borough, in $1438 .^{15}$

There were boroughs of much greater importance than Woodstock or Plymouth which had no grant of the farm in fee at any time within our period. Leicester had none till ${ }^{5} 58,{ }^{16}$ and what it got then was rather fitful. Madox could find no trace of Reading's fee-farm rent ${ }^{17}$ till the latter half of the sixteenth century. Liverpool illustrates those boroughs which had an

1 Stevenson, Records of Nottingham, i, p. 3.

2 Hudson and Tingey, Records of Norwich, i, pp. xvi-xvii.

${ }^{3}$ Lenihan, Limerick, p. 47, a. I 197.

4 Caulfield, Council Book of the Corporation of Cork, p. x. Early in the thirteenth century.

5 Money, Newbury, p. 66.

- Roots, Charters of Kingston upon Thames, p. 21 . It may have been at feefarm tcmp. Henry II: see Plac. IVestmon. Abbr., p. 4.

7 Ferguson, Charters of Carlisle, pp. 2, 3.

${ }^{8}$ C.C. R., i, p. $9^{6 .}$

9 last, Portsmouth Records, p. 573.

10 R. $/$., ii, p. 220: "dominus Henricus rex . . tradidit ad feodi firmam."

1 Vilom, Tenures of Kent, p. 160.

12 C. C.. R., i, p. 417.

13 Churter of Kochester, P. 4.

it Ballard, Woodstock, p. I7.

is II. M. (.., Rep., 9, pt. I, p. 272.

16 Bateson, Recorls of Leicester, iii, p. xix.

17 Rearling hatl a grant of the Firma Burgi (see Guilding, Reading Records, ii, P. $5^{2}$ ) but the date of the grant is unknown. Rearling was an ancient borough, at first abbatial, which may account for the proor quality of its early records; later it was royil. The abbot nominated the master of the Gild Merchant, which finally became the corporation and its master the mayor. 
intermittent farm; it was granted the privilege for varying periods at varying intervals, ${ }^{1}$ till finally it, like most other boroughs, bought out its lord. A few places still pay a fee-farm rent, sometimes to private persons to whose ancestors or legators the rent was granted by the crown. ${ }^{2}$

It is plain that a grant of the farm in fee was a comparatively late feature of burghal development. Burgage tenure would have been exactly what it was though not one city or town in England had excluded the sheriff by marks of silver and marks of gold. Valuable as was a grant of farm in fee as a means of maintaining personal liberty and burghal autonomy, it was no distinguishing mark of a borough; there were boroughs with it and boroughs without. Burgage tenure, on the other hand, was such a mark, for every borough must have it, and it could not exist outside a borough. ${ }^{3}$

1 See Baines, Liverpool, pp. 94, r6o. In $\mathrm{r}_{3}$ Henry II it had a grant of the farm for four years for $£_{I}$, in $\Upsilon_{354}$ for ten years for 50 marks, and so on till temp. Car. II, when the town bought out its lord.

A few places were held by their burgesses in fee though they could show no evidence of any grant. Probably they had once made what at the time were supposed to be temporary arrangements with their lords, which were continued from year to year till they became customary. Such boroughs were usually baronial; barons' records were not so thorough as the king's. A change of lords might bring trouble in such a case (see Atcheson, Case of the Borough of Petersfield, pp. $\mathrm{I}_{3}-\mathbf{I}_{5}$ ), but probably in many baronial boroughs the custom was never infringed.

2 This was the case at Chester (in I835) which paid its rent to the Marquis of Westminster, who had bought it from the crown (Parliamentary Papers, r 835 , xxvi, p. 2628). In 1887 the Firma Burgi at Doncaster, which was alienated centuries ago by the crown, and toward which went a few chief rents, was still being paid to a private person (Tomlinson, Doncaster, p. 33 , note q, and p. 27 , note h). The Treasury still receives the fee-farm rent from Grimsby (H. M. C., Rep., I4, pt. 8, p. 242, a. 1895).

${ }^{3}$ See Coke, Commentary upon Littleton, sec. xrob et pass. See also Elton, Tenures of Kent, pp. $\mathbf{1 5}^{2-1} 78$. The prior of Merton had held a messuage in Southwark. Borough and tenement came separately into Henry VIII's hand; he granted the tenement along with lands in Essex, all to be held in free burgage. The tenant died intestate and his property was the subject of a plea, during the process of which the court held that lands outside a borough could not be held in burgage, and if so granted must be held in socage. See also C. I. M., Henry VII, i, p. 282, 7 Henry VII: "Two burgages in Hatherlegh, worth 2 d., held . . . in free socage."

Representation in Parliament was, like a grant of the Firma Burgi, a burghal privilege and not a test or mark of a borough. In some boroughs, as Hereford and Carlisle, the limits of the parliamentary and borough franchises were not coincident. 


\section{Burgage Tenure in Domesday}

Though few of the records and sources, from which our conclusions so far have been drawn, reach to within half a century of the Conquest, it does not follow that burgage tenure is of post-Conquest origin. As Maitland puts it, when the age of charters began it found a tenure established in the boroughs. The earliest charters are usually very brief; they merely confirm the customs of a borough without stating what these were. Then from a few charters making new boroughs of vills we learn some of the customs of the old. At a later period, in most cases, these customs began to be codified, often because some new borough, in adopting a customal, was careful that there should be no question as to what its laws really were. ${ }^{1}$ How old are these customs, especially those which relate to tenure in the boroughs? Domesday is an ancient record; it bears witness to many economic and legal features in King Edward's day and in King William's. What does it tell us concerning conditions of land-holding in the boroughs? Not so much as one could wish, as far as individual boroughs are concerned." Domeslay is a 'geld-book,' an eclectic geld-book at that; it has an eye single to taxation. Unless tenurial customs were revenue-producing, they got scant attention or none. Yet from various items, here a little and there a little, some knowledge of burgage tenure in the Domesday era can be gained.

As to borough customs in general there seems to have been no change from Edward's day to William's. This is sometimes distinctly stated, as at Dover. ${ }^{3}$ Wallingford. ${ }^{4}$ and Hereford. ${ }^{5}$

1 For instance the burgesses of Ifereford gathered together their customs for the new burgesses of Haverfordwest, and charged the latter $\mathfrak{L}_{5}$ for their scrivices.

2 Fxcept in a few boroughs, as Chester and York. See D. B., i, ff. $262 \mathrm{~b}, 29 \mathrm{Sa}$.

" D. B., i, f, 1a: "omnes hae consuetudines erant ibj quando rex Willelmus in Angliam venit." In this and the following quotations the "customs' may refer to both legal and financial customs.

"Ibid.. i, f. 5fa: "Modo sunt in jpso burgo consuetudines omnes ut ante fuerunt."

s Ibid., i, f. 179a: "Modo hahet rex civitatem . . . in dominio et anglici burgenses ... habent suas priores consuetudines." 
King Henry's part of Liber Winton' (1 103-15), an appendix as it were to Domesday, corroborates the evidence of the latter, especially in the matter of the burgage rent or landgable. ${ }^{1}$ The method of compilation of Liber Winton' confirms Maitland's suggestion that in many of the items concerning boroughs in Domesday the landgable was often contained in the financial customs. $^{2}$ The only alternative to his opinion is that in many boroughs the bulk, or sometimes all, of the messuages paid no rent or gable whatever. ${ }^{3}$

This gable, or more commonly landgable, was naturally a very important burghal feature to the compilers of King William's great rate-book; it ranked with other sources of revenue, such as profits of pleas, markets, and tolls. The landgable is sometimes given as a lump sum, sometimes what each tenement must pay; at times the name appears without the amount. ${ }^{4}$ In such cases the occupying burgesses are often charged with it, as at Canterbury, ${ }^{5}$ where, however, other dues than the landgable seem to have been included in the return. ${ }^{6}$ Gable T. R. W. differed but little from gable T. R. E., ${ }^{7}$ except where revolt

1 It abounds in such items as: "Domus ... reddebat $\mathrm{xv}$ d. de langabulo et omnes consuetudines tempore R. E. Modo G. tenet eam et facit consuetudines similares" (D. B., iv, Liber Winton', f. 8). For other entries of the same sort see ff. 8,8 b, II, I Ib, etc. The 'customs' are not legal but financial.

2 This record follows the plan of the Winchester streets, and at first the landgable is separately given for each house. Then the jurors, or the clerks, or probably both, got tired or impatient; the entries start at the end of a street in due form, ' langabulum et alias consuetudines,' but soon 'omnes consuet.' creeps in and the totals go up; the landgable in such cases is certainly included.

${ }^{3}$ In nearly every borough a varying number of messuages paid no landgable. Possibly some never paid any.

4 'Hawgable' is not used in Domesday or Liber Winton'.

5 D. B., i, f. 2a: "In civitate Cantuaria habuit rex Edwardus 1 et $\mathbf{i}$ burgenses reddentes gablum."

${ }^{6}$ Ibid., i, f. 2a: "Radulfus tenet alias xi masuras de episcopo in ipsa civitate [Canterbury] . . . et reddit xi s. ii d. i obolum." This seems much too high for landgable alone. It was about $6 \mathrm{~d}$. for the average messuage in Winchester, and that was high.

7 As at Pevensey (ibid., i, f. 2ob) where "T. R. E. fuerunt xxiiii burgenses in dominio regis et reddebant de gablo xiiii s. vi d. . . Modo habet ipse [Count of Mortain] in dominio lx burgenses reddentes xxxix s. de gablo." The gable in each period averaged a little over $7 \mathrm{~d}$. for each masura. 
or fortification had entailed waste, ${ }^{1}$ and in nearly all these records it varied for each house. ${ }^{2}$

Perhaps $5 \mathrm{~d}$. or $6 \mathrm{~d}$. would not be far from the average landgable in the boroughs of southern England. Except in Winchester, however, very few messuages paid this amount. Most of the individual landgables were much lower; a few very much higher, ${ }^{3}$ though there was occasionally an apparent exception, ${ }^{4}$ due probably to intrusion by mesne lords. At times toll and gable were given as a lump sum. ${ }^{5}$ In the Confessor's day Oxford, like London, seems to have been at farm, but probably not feefarm. ${ }^{6}$ At Huntingdon ${ }^{7}$ and Northampton ${ }^{8}$ the rents were about the same as in the boroughs previously instanced, both in amount and variability. At the latter town there was apparently no difference in this respect between the French and the English borough. Nottingham's landgable was of like sort. ${ }^{9}$ With Hereford there appears another fashion as regards the bur-

${ }^{1}$ D. B., i, f. ${ }_{5}^{6 a}$. "In burgo de Walingford habuit rex Edwardus viii virgatas terrae et in his erant cclxxvi hagae reddentes xi libri de gablo. . . . Modo sunt in ipso burgo consuetudines omnes ut ante fuerunt, sed de hagis sunt xiii minus, pro castello sunt viii destructac." A few haws might be destroyed, but " de super plus sunt xxii masurae francigenae reddentes vi s. v (.," an average of $3 \frac{1}{2} \mathrm{~d}$. for each.

2 As at Pevensey (D. B., i, f. $20 \mathrm{~b})$ where there were rents of $20 \mathrm{~d}$. each, i $2 \mathrm{~d}$. each, 5 of $2 \mathrm{~s}$. for all, and so on. At Wallingford (D. B., i, f. $\left.5^{6 \mathrm{a}}\right) 22$ masurae paid $6 \mathrm{~s} .5 \mathrm{~d}$. for all, 20 masurac paid i 2s. Iod. for all; 27 haws paid 25 s. for all, 6 haws paid $44 \mathrm{~d}$. for all; there were several messuages at $4 \mathrm{~d}$. each, $2 \mathrm{~d}$. each, and so on.

${ }^{3}$ 6d. was the average rent at Taunton T. R. E. " Ibi lxiiii burgenses reddentes xxxii s." (I). B., i, f. 87 b).

4 See D. B., i, f. 143a. At Buckingham T. R. W. one burgess paid 2s. 2d. to Earl Hugh and $5 \mathrm{~d}$. to the king, another 2 s. to Ernulf de Ilesding and $3 \mathrm{~d}$. to the king, another 25.4 l. to Hugh de Bolebec and $2 \mathrm{~d}$. to the king, and 4 burgesses paid $2 \mathrm{~s} .5 \mathrm{~d}$. to Manno Brito alone. The lower sums were probably the landgables proper.

s Ibid., i, f. 26a. "Burgus de Lewes T. R. E. reddebat vi libras et iiii sol. et iii obolus de giblo et de theloneo "; there were 127 burgesses.

${ }^{6}$ See ibid., i, f. 154a. The city paid $£_{20}$ and some honey for all custons. T. R. WV. 10 mansiones paid 3 s: "Omnes sunt vastae practer unam." 7 messuages paicl 5 s. sil., 4 paid is. 5 d., etc. T. R. J. mural 'mansiones' were free of custom, "excepta expeditione et muri reparatione."

7 Ibid., i, f. 203a. 20 'mansiones,' which had been destroyed to make way for the castle, had rendered $16 \mathrm{~s} .8 \mathrm{~d}$. for all customs, an average of $10 \mathrm{~d}$.

$8 \mathrm{Ibid}$, i, f. 2 I gia. 23 houses rendered 29 s. 4 d., 2 rendered $16 \mathrm{~d}$. each, I paid 4 d., 12 paid $3 \mathrm{~s}$. for all, 4 paid 4 s. for all, etc.

Ibid., i, f. $280 \mathrm{a}$. I1 domus for 4 s. 7 d., 48 for 36 s., etc. 
gage rents; they were uniform in their incidence and somewhat higher than in the rest of the Domesday boroughs. ${ }^{1}$ Shrewsbury may have had a landgable of like sort. ${ }^{2}$ At York the landgable was so low as to be practically uniform for each messuage, ${ }^{3}$ but this uniformity had nothing in common with the uniformity at Hereford. At Lincoln ${ }^{4}$ and Norwich ${ }^{5}$ as well as York this low and virtually uniform landgable was the same in the Confessor's day as in the later middle ages. ${ }^{6}$

Cambridge shows exactly the same conditions in respect to the landgable during and before the Domesday era as centuries later. In Edward's reign and in William's there were messuages which paid none. ${ }^{7}$ The gable and the financial customs were separated at Cambridge. The amounts, which were the same T. R. E. and T. R. W., were nearly equal; if the same proportion held in other boroughs this may show that the gable was about half 'of all customs.' 8 The landgable was $£_{7}$ two orae $2 \mathrm{~d}$. This is the 'high gable' rental, which in I $_{4} 83$ was $£_{7} 2$ s. $\frac{3}{4} \mathrm{~d}$., and which, for Cambridge at least, affords complete proof for the age and incidence of the burgage rents.

Domesday knows the burgess well. It does not know the burgage under that name; the common expression is masura or mansura, sometimes domus, sometimes mansio. All these

${ }^{1} D$. B., i, f. I79a. Within the walls each "integra masura reddebat" $7 \frac{1}{2} \mathrm{~d}$., probably the gable, together with $4 \mathrm{~d}$. for hiring horses, and a few other trifles, the sum of all these services being so close to $12 \mathrm{~d}$. that this is probably the reason why Hereford is supposed to have been among the later shilling boroughs. Masuras without the walls paid only $3 \frac{1}{2} \mathrm{~d}$. each.

${ }^{2}$ Ibid., i, f. $252 \mathrm{a}$. There were 252 burgenses and 252 domus; the total amount ' de gablo' was $£_{7}$ I6s. $8 \mathrm{~d}$., an average of a little over $7 \mathrm{~d}$. Nothing, however, is said of horse-hire or other incidental services.

${ }^{3}$ Ibid., i, f. 298a. " cccc mansiones . . . reddunt meliores i d. et aliae minus." York is the largest borough which has a place in Domesday.

${ }^{4}$ Ibid., i, f. 336a. "T. . . . habuit in civitate $\mathrm{xxx}$ mansiones ... de una quaque unum denarium, idest langabulum."

5 Ibid., ii, p. I 8 a. The landgable is apparently id. for each messuage.

6 See also Yarmouth, D. B., ii, p. i 8 a.

7 Ibid., i, f. r8ga. Alan the earl had "v burgenses nichil reddentes." The Count of Mortain " habet iii masuras et ibi sunt iii burgenses qui T. R. E. reddebant v s. viii d. i obolum, modo nichil reddunt."

${ }^{8}$ The common Domesday phrase is 'omnium consuetudinum.' The custons at Cambridge were $£_{7}$ (D. B., i, f. I89a). 
terms meant the same. Mansio seems to have been the favorite in the north, as at York and Lincoln. ${ }^{1}$ At times burgensis is used in exactly the same sense as masura or domus, as at Leicester, ${ }^{2}$ Stafford ${ }^{3}$ and Hertford; ${ }^{4}$ each may owe the gable. A burgess might be even a fraction of a house or a house a fraction of a burgess, as at Huntingdon. ${ }^{5}$ Not even a Domesday scribe was likely to mistake a burgess for a messuage. It seems therefore where the terms burgensis and masura are used interchangeably, as they were in many boroughs, that the rule was one burgess, one tenement. ${ }^{6}$ In some towns, however, there were more houses than burgesses; and in many there is no statement as to comparative numbers. 'These instances and illustrations make it plain that the 'burgage tenement' with its 'burgage rent ' existed in King Edward's day and probably long before it. ${ }^{7}$ We have the low fixed rent called, before and long after the Conquest, the gable or landgable, and Domesday shows clearly that the lands in the boroughs were held, not by leases nor in base tenure, but by this fixed heritable ${ }^{8}$ money-rent, and seldom by any additional service: this is burgage tenure. ${ }^{9}$ The case for the landgable may be closed. It has surely proved its claim of ancient uninterrupted descent.

Domesday has little to say of other matters touching the tenure, for they were seldom of financial importance. At times the scribes, apparently in idle moments, do note down parts of bor-

1 At Nottingham (see D. B., i, i. 280a) the mansio may have been a large holding containing smaller sub-holdlings, "iii mansiones in quilous sedent xi domus": elsewhere mansio is the same as masura. Terra oecurs in Liber Winton".

${ }^{2}$ D. B., i, 1. 230a: 'burgensis pertinet' or 'domus pertinet.'

${ }^{3}$ Ibid., i, f. 246a, burgensis = mansio.

"Ibid., i, f. 132a: "Ibi crant cxlvi burgenses in soca regis Eduuardi. De his habet molo comes Alanus iii domos."

5 Ibid., i, f. 203a: "sunt cxl burgenses dimidio domus minus."

5 See ihid., i, f. zrga, etc: " "T. R. E. fuerunt in Northantone in clominio regis $\mathrm{l}$ burgenses habentes toticlem mansiones."

7 . Is 'burgagium' is not used in Domesday there is no place for "burgage rent '; this term is virtually unknown in the older boroughs all through the middle ages.

${ }^{8}$ Relief is not paid except for inlacritance. It is found in some of the comparatively less free I)omesday boroughs.

- See F. W. Maitlanrl, Domesday Book and Beyond (Cambridge, 1897), pp. 198199. There was even something like the fee-farm rent at London and Oxford. 
ough customs, as those of Dover and Chester, ${ }^{1}$ while the detailed Newcastle customal dates from Henry I's reign. ${ }^{2}$ Such customs do not grow up in a night, unless it be the night of history. Were the older urban communities ever affected by the feudal incidents? By only those apparently which had Saxon prototypes, as relief for heriot, and even heriot existed in by no means all the boroughs. Do freedom of sale and devise antedate the Conquest? They certainly do for bookland; they certainly did not come with the Normans. ${ }^{3}$

The conviction which is borne in by a survey of tenurial burghal institutions in the Domesday era is, that when the country at large was passing under the yoke of feudalism, the boroughs retained and later developed their tenurial liberties; that this development, fostered in many towns by the commercial spirit, had reached a stage in the eleventh century of sufficient strength to save the boroughs from the feudalization which was then overspreading the land, the predominance of which was hastened and assured by the incoming of the Normans. But that conditions of land transfer in the preConquest boroughs had attained or even approximated the degree of freedom which is found in such a place as Cambridge in the twelfth and thirteenth centuries is quite improbable, for there was no demand for such freedom.

Sale there was at times however. At Hereford Peter of Valongies (Valognes) had bought houses from Ulwi of Hatfield, who was free to assign or sell them. ${ }^{4}$ All the houses in Hereford were alienable, but not freely alienable; sale must have the consent of the praepositus. ${ }^{5}$ Sale lay under no restriction at Torskey ${ }^{6}$ and at Lincoln was hampered only by the kin's retrait. ${ }^{7}$

1 See $D . B .$, i, ff. ra and 262b. $\quad{ }^{2}$ See Stubbs, Select Charters, pp. rro-ir 2.

${ }^{3}$ For survival of this term see Elton, Tenures of Kent, p. г6г. The 'bookland' of Alfred's law (cap. $4 \mathrm{I}$ ) seems to be exactly the same as the 'land of purchase' of the twelfth and later centuries.

${ }^{4} D . B ., \mathrm{i}, \mathrm{f} . \mathrm{r} 32 \mathrm{a}$.

5 Ibid., i, f. r79a. The third penny was due him as well.

6 Ibid., i, f. 337a: "quicunque eorum mansionem in eadem villa habebat neque intrans neque exiens theloneum dabat." Probably the reference is to "Outpenny and Inpenny' and not to market tolls.

7 Ibid., i, f. 336a. This could be evaded with the king's consent. 
At Chester delay in the payment of the landgable entailed an amend of ros.; default cost a burgess his tenement. ${ }^{1}$ At Gloucester nearly half the tenements seem to have changed holders through sale in the days of William the Red. ${ }^{2}$

Heriot and relief seem to have been most common on the Welsh border; the former was an incident at garrison towns such as Hereford ${ }^{3}$ and Shrewsbury, ${ }^{4}$ the latter at Chester. ${ }^{5}$ Elsewhere relief and heriot, when they existed at all, ${ }^{6}$ seem to have been paid by a small and perhaps aristocratic number of burgesses. ${ }^{7}$ The heriot was that of the law of King Canute. In the Confessor's reign marriage is found at Shrewsbury only. ${ }^{8}$ Forfeiture, in Dover at least, was peculiar; only half a felon's tenement was taken by the king. ${ }^{9}$ That this was the common burghal practice is unlikely; both before and after the Conquest he who forfeits, forfeits all. ${ }^{10}$ In both Edward's day and William's, especially at such boroughs as Canterbury and Dover, there was aristocratic holdership, some of which seems to have been mesne,

${ }^{1} D . B ., \mathrm{i}, \mathrm{f}, 262 \mathrm{~b}$. The rule in nearly all the boroughs. Until the borough obtained a grant of the iarm in fee the lord got such a tenement. At Hereford (ibid., i, f. 179a) the praepositus must get another and solvent tenant, as at Uttoxeter in the thirteenth century and at Agardsley in the fifteenth.

${ }^{2}$ Cole, Rental of the IIouses in Gloncester, p. xiv (return of the landgavel, a. 1006r101). There were 200 burgesses in the king's demesne, 97 dwelling on their own inheritance and 97 in houses which they had bought.

${ }^{3}$ D. B., i, f. I 79a. At the death of a burgess who had served as a horseman the king took both horse and arms; if as a foot-soldier, the heriot was commuted for ros.

"Ibid., i, f. $252 \mathrm{a}$. At the death of a burgess " in dominio regis" the king took 10s. This is called relief; it seems to have been a commutation for heriot.

s Ibid., i, f. 262b: "Qui terram suam vel propinqui sui relevare volebat $\mathrm{x}$ s. dabat."

"Which is not the rule. At York (D. B., i, f. 29Sb) "burgenses . . . non dant relevationem."

7 Is at Cambridge (D. B., i, f. ISga) where Picot the sheriff had $\mathfrak{E} 8$, a palfrey, "et unius militis arma," "de harieta Lagemannorum." This is a combination of both incidents.

8 I). B., i, f. 252a: "Mulier accipiens quocunque modo maritum si vidua erat dabat regi $x x$ s. si puella $x$ s."

9 Ibid., i, f. 1a: "De illa masura quam tenet Rannulfus . . . quae fuit cujusdam exulis [" utlage" is overwritten] . . dimidia terra est regis." What happened to the other half?

10 In Alfred's law, cap. 20, there is forfeiture of half to the king, but it was merely half the 'wer' and then only when the slain man was kinless. 
and practically none lowest. Aristocratic holdings seem relatively smaller in the Norman than in any other period, for so many towns passed into the royal demesne and so many territorial lords lost their possessions, that the king became lord of all the important boroughs, and of a large majority of the messuages therein.

Of all the burghal features here treated, commonest, clearest, and of lineage unbroken from the earliest period, is the landgable, whose difference in character, though not in kind, causes the older boroughs to fall into two general classes: one where the landgable was about the same for each tenement; the other where wide variations occur. The gable is low in both classes; and there were rents of a shilling, but no shilling boroughs. In the first class come most of the boroughs of the Danelaw, with the older boroughs of the shires, as far as we know them; even London seems to belong to this class. That is, the bulk of the boroughs held by the Danes and those which were founded to resist them, or fortified against them where already existing, were tenurially of the same order. ${ }^{1}$ In the second class came such a town as Cambridge ${ }^{2}$ where the average ' high gable' of $\mathrm{Id}$. or $2 \mathrm{~d}$. is found side by side with rents of $3 \mathrm{~s}$. or $4 \mathrm{~s}$. all through the middle ages. ${ }^{3}$

The most reasonable explanation for this inequality seems to lie in accumulation of masuras, the rents, which were possibly unequal from the first, accumulating with them. By subsequent divisions of land but not of rents, several masuras would become free from payment of gable ${ }^{4}$ while others paid a rent out of proportion to their size; such messuages, however, would be comparatively few. This is exactly the condition which was prevalent at Cambridge and elsewhere ${ }^{5}$ and which might have obtained,

1 Anyone not delirious with Roman fever knows that the London of continuous history dates from the period of the Danish wars.

2 I have taken Cambridge as an illustration intentionally and as the main excepion to the rule in the Danelaw.

${ }^{3}$ Domesday for the eleventh century; Rotuli Hundredorum for the thirteenth century; Cooper, Cambridge, for the fifteenth.

4 Possibly there were tenements which had never paid gable.

5 As at Oxford. At Cambridge the exceeding fluidity of realty exaggerated the inequalities of the landgable. 
and did obtain to some small extent, in the boroughs of our first class, had not their later foundation or development, ${ }^{1}$ together with the desire to induce settlement, caused the adoption of a perhaps symbolic rent so low as to be practically uniform, the customary penny hawgable. ${ }^{2}$ It is unlikely that Henry de Lacy ever heard of the Alderman of Mercia, but the causes which induced him, when founding Denbigh, to replace the usual shilling rent of the created baronial borough with the penny landgable of Lincoln may have been in part the same as those which influenced Alfred's son-in-law when making strongholds in the Midlands.

\section{English Burgage Tenure and the Laws of Breteuil.}

While the tenure in the older boroughs of England is plainly an institution of native growth, there was a group, or rather there were several groups, of towns where the conditions of land-holding bore the marks of a greater or lesser amount of foreign influence. This outside influence, with the boroughs in which it is (or is supposed to be) found, has been made the subject of what may be thought rather unnecessarily detailed treatment. the lack of consequence and small effectiveness of these boroughs being considered, under the title "The Laws of Breteuil." 3

Bretcuil was a Norman iille of no particular importance, whose innocent young life came to a sudken and viokent chose,

1 York, Lincoln, etc., and even london were wasted by the lones and had virtually to start anew.

2 "lere has been suggested another explanation for low and variable rents whose only defect is that it does not explain; this is that sone lord of a manor mate at borough plecemeal. In the latter midlle ages there were illustrations of this process at Plympton and l artmouth. The lord gave messuages at varying rents, haretly any two bejing the same, and continued to to so at Plympton long after be

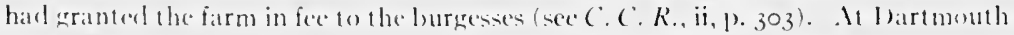
there secms to haw been a borough already in existence to which the lord was making ardlitions; the rents varied approximately aceorling to the value of the tenenents and were sedem the same. But in sur ha borough as cambridge there were tox many lords, $f(x)$ many equal rents and houses with no rents, and too great a disproportion betwen the value of a tenement and its gable for this explanation to suffice. I'lymouth and Dartmouth are ahomermal anyway; when in the welfth or the thirteenth century a lord wished to start a borough he did so at at stroke.

${ }^{3}$ Miss M. Batesen, in English Mistorical Retiai, rols. xv, xvi. 
and whose laws or customs exist only as they have been more or less imperfectly copied into the charters and customals of those towns which professedly received them; from these sources Miss M. Bateson, the writer of the series of articles in question, has reconstructed the 'Bretollian Laws,' at least as to their purport. It is seldom safe, in England especially, to take literally the statement that one borough had the laws of another. Claims of like customs there certainly were, and often the leading likeness was the claim, though sometimes the resemblance was almost exact as at Bristol and Dublin with its followers; sometimes, as at Winchester and Gloucester, there was identity without any claim. ${ }^{1}$ A glance at the boroughs in Miss Bateson's list is enough to show that they differed widely, in respect to their tenurial customs, among themselves; in many a charter the term Laws of Breteuil seems to have meant only what the grantor or grantees knew of them; certainly it did not always mean the same things.

With some exceptions the boroughs in question are found in Ireland or on the Welsh marches. They are chartered and most of them are created boroughs, looking back to some baron as founder. In boroughs neither created nor baronial, as Hereford and Shrewsbury, ${ }^{2}$ Miss Bateson's opinion was that the privileges given to the knot of Norman traders, who formed a bourg near the royal castle, spread into the long and previously settled English borough, - though in respect to the tenure the spreading was exactly the other way. ${ }^{3}$ She concluded, with like or equal logic, that the term burgage tenure, originating with these Norman bourgs, spread from them to the older boroughs, "where already, in the king's gafol, there was a low payment made by each house, which could not easily be differentiated from a rent." 4

1 Professor Charles Gross ("The Affiliation of English Boroughs," printed as an appendix to The Gild Merchant (I890), i, pp. 24I-28I) shows how little meaning there often was in the term ' derived liberties,' particularly in England. Customals virtually identical in one century might differ widely in the next. Witness the course of sale and devise.

2 Both of which Miss Bateson claims as Bretollian.

${ }^{3}$ Borough-English and devise (of purchase) became common to all Shrewsbury. The former custom was called there the 'Hock-Day' tenure.

4 Miss M. Bateson, in English Historical Review, xvi, p. 345. In other words, Miss Bateson made English burgage tenure an institution of Norman origin. 
It is scarcely surprising that the gafol, or gable, 'could not easily be differentiated from a rent,' for no one has yet been able to distinguish between a thing and itself. The gafol is the rent; it was the rent in the Confessor's day, in the Conqueror's reign, and in that of his youngest son, ${ }^{1}$ whether at Cambridge as a lump sum called the landgable, or at Winchester and Lincoln as a rent due from the individual urban tenement. That the term burgage tenure is French is undoubtedly true, but not particularly odd in view of the fact that most of the terms of the land laws are French. That the older boroughs adopted this name, though at a late period as a rule, is also true, but proves nothing as to age or source of the tenure. Free urban tenure. like the law, is older than its technical terms: English law and legal institutions started a few years before the Conquest. In the Domesday era the term burgage was not apparently in use in any borough, English or Anglo-French, and in Henry I's day there was but a suggestion of it at Winchester, yet in both periods there were French and English boroughs side by side at Hereford, Nottingham, and other towns. Domesday tells us that each section at Hereford had its own customs; ${ }^{2}$ that those of the French iille should be Norman is not wonderful. Instead. however, of the extension of Norman tenurial customs into the English part of the borough, which Miss Bateson imagines, it is very evident that the spreading was the other way. For example, devise. unknown in Nomandy, became a common Hereford custom.

In regard to the basic facts on which this Bretollian theory is founded there is no question. Certain boroughs in England and Ireland, not one of which was of any importance at any time during the mediaceal period, started under Norman lords and with Norman customs. ${ }^{3}$ or at least a claim of having such customs. ()f these, according to Miss Bateson, the following were taken bodily from the tenurial laws of Breteuil:

"Sce l homesday and Liber W'inton"; also .Mr. J. IJ. Round's essay " Wancegeld and

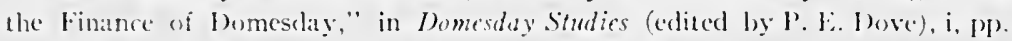
$77^{-142}$, where he shows this to be the case with his usual vigorous and scholarly abilits:

2 The reference seems $t o$ be to all sorts of customs, not financial customs merely.

3 For the reconstructed Breteuil customal, or rather Miss Bateson's idea thereof, see English II istoricul Reaiew, xv, [11. 754-757. 
(I) A clause giving the size of the original burgage. ${ }^{1}$ In fact the clauses in these charters seldom mentioned the size of the burgage at all; that was left to the burgesses. What the charters specified was the amount of land in the fields accompanying each burgage. Nor did the founders of the boroughs in Ireland necessarily get the idea from Breteuil; an identical method was followed when Bristollian boroughs were founded in the same country and at the same time. ${ }^{2}$ In any event, when a borough was created, especially in wild Ireland, what else could its creator do in regard to land ? If all that a burgess might acquire should be held under burgage tenure where was the tenure to stop? Strictly there would be no limit. When de Lacy made Congleton a borough he let all the land the burgesses could gain be held in free burgage, but his men with their holdings were there already, and outlying manors probably fixed the borough bounds. Henry the Fowler used this idea of a definite assignment of land with each tenement, yet he did not get it from Breteuil. However, had the grants of land with each burgage in the Bretollian boroughs been even approximately equal, and equal to the grant at Breteuil, it might perhaps be assumed that the custom of that Norman town had served as a precedent. Instead, however, of being uniform the assigned amounts of land varied from half an acre to seven acres, and, furthermore, no one knows how much land went with each burgage at Breteuil!

(2) An entrance or departure fee into or from a burgage or a borough. ${ }^{3}$ This incident existed at some of the Bretollian boroughs in England. It is found also at Norwich, whose tenurial customs were certainly not those of Breteuil; while in the most

1 Miss Bateson uses this expression, 'size of the burgage,' in a wholly different way from that in which I have used it in previous pages (see pp. 94 et seq., 99, ror). When the mediaeval burgess spoke of his burgage, or rather messuage, he did not ordinarily include his acre-strips. Under the heading "The Nature of the Burgage" an attempt was made (see pp. 99 et seq.) to discuss the question (as Miss Bateson raised it) and the conclusion reached was that the specific number of acres of the charters was granted with each burgage, came under the burgage tenure but was never considered as part of any particular burgage (save possibly in two instances), and paid no burgage rent.

2 See the charter to Rathcool, Gale, Corporate System of Ireland, app., p. x.

3 What we have called 'inpenny and outpenny.' See pp. 57, I27. 
Bretollian of all the boroughs, those of Ireland, no such fee was ever known.'

(3) A clause guarantecing freedom from marriage. As marriage was unknown in both Norman iilles ${ }^{2}$ and English boroughs, ${ }^{3}$ this clause needs no discussion. ${ }^{4}$

(4) Retrait Lignager. There was not the smallest necessity for borrowing this custom from Breteuil, when it was common not only to England but to all northern and western Europe. ${ }^{5}$

(5) Alienation fees. The claim of a Bretollian origin for this incident, when fixed, and only then, seems to be well made. The ultra-Bretollian boroughs of Ireland, however, never knew a fee at alienation. ${ }^{6}$

(6) The uniform shilling rent. Of all these Bretollian tenurial customs, almost the only one which Miss Bateson has shown to be common to the Bretollian boroughs is the uniform twelvepenny burgage rent. However this rent of a Norman shilling ${ }^{7}$ existed in boroughs in both Ireland and England ${ }^{8}$ which so far from having the laws of Breteuil did not receive Norman laws of any sort. ${ }^{9} \quad$ Yet on this uniform rent of a shilling hang all the tenurial laws of Breteuil, and from it, in Miss Bateson's opinion,

I The fee probably comes from a foreign source, however, even in Norwich, where there was more or less French influence.

2 Génestal, La Tenure en Bourgage, pl). 21, 2S-20.

3 T. R. E.., there was something like it at Shrewsbury only. See p. 164, note 8.

- See p. I 2 for Marriage.

5 Furthermore its time limit and the procedure in the matter of its enforcement in the Bretollian boroughs were linglish rather than Norman. See below, Pp. 173, 17 .

6 To these six main points which Miss Bateson scized on as Bretollian she adderl a bew others of rare occurrence and trivial consequence. One concerns the suppesition that a burgess who has sold his burgage " with continue to live in the town, and another relates to the reluthling of a dest rosed burgage.

7 Rent: of this amount were common in Normandy. At Vemenil the rent of 121. dict nut increase with the number of houses, just as in the English Bretollian boroughs. but in this connection there were contradictory statements in the Norman charters.

8 Watterford and Pontefract to wit; the former having Bristol and bublin customs, the batter having those of (irimsby. See Parliamentary Papers. Is35,

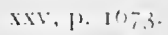

9 Cardifi wat une of the boroughs with Norman but not Bietollian customs. Its burgilge rent- were a zll. cach. 
arose the idea of a uniform tenure, ${ }^{1}$ a conclusion worth neither denial nor dispute. ${ }^{2}$

Such was the ' uniformity of tenure' which has been supposed to have resulted from a gift of the laws of Breteuil, and whose influence has been thought sufficient to lend a name to the tenure in the older boroughs. As far as Breteuil itself was concerned it is unlikely that it lent even that. The actual state of affairs seems to have been as follows. Those boroughs founded by barons during the Norman period as Bretollian boroughs, and settled mainly by Norman burgesses, probably did have the laws of Breteuil if their charters or customals so stated; such boroughs, however, were very few. Those founded at a later period seem to have had only parts of the Bretollian laws, and not important parts at that; their founders, knowing but portions of the laws of the little ville, and those portions only by repute, apparently filled in the gaps with Norman customs in general. If, however, the more inclusive 'Norman' be substituted for 'Bretollian,' the tenure in these baronially-founded semi-foreign little boroughs was uniform in respect to a custom vastly more important than any of the points of resemblance so carefully enumerated by Miss Bateson, -- more important even than such a weighty matter as the twelvepenny burgage rent, - there was neither sale of inheritance ${ }^{3}$ nor devise of either sort of realty in Norman villes, and in those boroughs of England and Ireland which professedly had Norman customs. Concerning freedom of devise, the most important legal feature of English burgage tenure, ${ }^{4}$ Miss Bateson seems to have known nothing whatever. Without attempting to underrate Norman influence in general in English boroughs, we may say that it did not affect the tenure at all except in unimportant towns which formed a group apart, and that in

1 English Historical Review', xvi, pp. 343-344.

2 Even on the negative side, as it were, these Bretollian boroughs varied, not only from their supposed original but among themselves. There was no heriot nor relief at Breteuil apparently. There was, however, at such imitative boroughs as Manchester, Stockport, Salford, Oswestry, and other towns which were or claimed to be Bretollian. Miss Bateson considered Denbigh a Bretollian borough. Such of its tenurial customs as are known were English or Gascon.

3 Sale in need crept into a few Bretollian boroughs in England.

4 Bracton and Littleton so considered it. 
some even of these it was overcome in time by freer English custom. ${ }^{1}$

\section{Urban Tenure in Normandy, the Netherlands, AND GERMANy}

Whatever the influence which the customs of a single Norman ville or of all the towns of Normandy exercised on the tenure of some small English boroughs, a short account of urban tenure, in regions where Germanic land laws held, may serve to bring into relief the resemblances and differences of this tenure in the countries to which, racially and geographically, England is most closely allied.

In Normandy ${ }^{2}$ one who held in burgage was not subject to the feudal aids; so decided the Exchequer of Normandy in the thirteenth century. ${ }^{3}$ Homage was not done nor fealty sworn. ${ }^{4}$ Relief and lods et ientes were incidents of the tenure in apparently a minority of the silles. ${ }^{5}$ According to the coutume reformée relief seems to have been usually " 3 sols pour mansions, masures, et manoirs " containing less than an acre. and M. Génestal considers that, as most burgages were of this sort, relief was in general 3 sols for each. ${ }^{6} \quad$ Lods et ienles, though called the treizieme, were really one-twelfth. ${ }^{7}$ There were also fixed alienation fees; at Flers this fee was four deniers tournois at each sale; ${ }^{8}$ at Monti-

1 To wit, sale of inheritance appeared in such boroughs as Altringham and Rhuddlan, and even free devise in the former. Possibly the very limited devise at Manchester was initative of a temporary custom of the free non-military tenure outside the villes in Normandy.

2 Our authority is Génestal, La Tenure on Bourg'age: Eilude sur la Propriété Fonciere dans les Villes Yormands. The order of the following account will be the order of M. Ciénestal's work, to the purport of which we trust we shall do no injustice.

${ }^{3}$ Ciénestal, La Tenure, P. 21, 12, 1239. A demand had been made on the bourgeois of Itite du Theil for an 'aide de mariage.'

4 Ilid., p. 64. M. Cienestal states this on the authority of the coutume of the sixteenth century.

I Ibid., HI. 32-33. These incjelents are dealt with together and somewhat more vaguely than one could wish.

6 Ilid., p. 115. It Havre relief was' ' 3 sols tournois.'

7 Ibid.. p. to. $8{ }_{3}^{11}$, of the price paicl, silys our atuthor.

8 Ibid., p. 115 . Though relief wals owel at IIave there was no alienation fee. This, like many of the examples which .I. (ienestal was obliged to use, is of very late date. Havre was founded by Francis I. 
villiers there were relief and lods et ventes, ${ }^{1}$ and in addition some burgages owed villein service or corvée. ${ }^{2}$

Retrait lignager apparently existed in all towns, but the period of its effectiveness was limited to the interval between public announcement of the sale and payment of the price agreed on, an interval supposed to be a prescriptio de hora and less than a day; in the sixteenth century this interval became forty days. ${ }^{3}$ Dower rights were confined to 'acquits' and seem to have been half of such burgages. ${ }^{4}$ In the Norman towns there was one sort of tenement which had no English counterpart, in theory at least, the franc alleu, or allod. ${ }^{5}$ Such tenements, owing no services and having no lords, were found mainly in the older towns, as Rouen, Caen, and Bayeux. ${ }^{6}$ In the villes of Normandy, as in other towns of northern Europe, a few burgages owed rents expressed in terms of hens; ${ }^{7}$ the usual rent, however, was in money, and, at least in chartered and created villes, was commonly I $2 \mathrm{~d} .^{8}$

1 Génestal, La Tenure en Bourgage, p. i 6 . Not all the burgages were liable to them.

${ }^{2}$ Ibid., p. I19. A small amount of villein service, such as a few days' work at harvest, existed till the Domesday era at one or two towns on the Welsh border. See also Ballard, British Borough Charters, pp. $94 \mathrm{f}$.

${ }^{3}$ Génestal, La Tenure en Bourgage, pp. 35, 81. The forty day period is that of the coutume reforméc. This movement toward greater restriction in Normandy may be compared with the change from restriction to freedom in England, Germany, and the Netherlands. Was it due to French influence after 1203 ?

${ }^{4}$ Ibid., pp. 35-47. M. Génestal gives much space and attention to this subject and that of 'droits successoral' (ibid., pp. 47-55), subjects pertaining rather to Intestacy, were it not that realty descended in no other way in the Norman villes.

${ }^{5}$ In the English boroughs there were many tenements which owed neither rent nor service, but the lord of the borough was their lord. The distinction between these and the 'francs alleux' is one of theory and descent.

${ }^{6}$ Ibid., p. 129: Legras, Le Bourgage de Caen, pp. 116-117. Some of the records quoted by $\mathbf{M}$. Génestal remind one of the items in Domesday; for instance a certain châtelain gave to a church in Louviers "unum burgensem cum suis tenementis" (La Tenure, p. 97) - though burgage tenure was always free tenure - just as in England lords have burgesses of rod., and so on.

7 Génestal, La Tenure en Bourgage, p. 99. Cf. Leicester and Portsmouth.

8 At St. Lezier it was $4 \mathrm{~d}$. for $12 \mathrm{ft}$. of frontage (ibid., p. 100), which recalls the I $2 \mathrm{ft}$. limit at Preston. In the fifteenth century the rule for rental and division (M. Génestal is probably speaking of created villes. See pp. 98-100 was generally as follows. The whole area of the ville was in large blocks, masurae, which were usually divided into lots, each with its house and curtilage, but the shilling rents lay on the masurae, which might or might not be of equal size, while each holder of a subdivision paid his part. 
In general this rent of a shilling seems to have been considered the outward sign of tenure in burgage. ${ }^{1}$ Devise was unknown, ${ }^{2}$ and escheat was the lord's when there failed an heir within the seventh degree. ${ }^{3}$

From M. Génestai's account, rather than the above brief description, it seems that not only was Breteuil typical of the Norman bourgs, but that almost any other bourg would have served equally well as a type. Most of them were apparently created, and had neither the freedom of Rouen and Bayeux, nor the villein service of some smaller towns. ${ }^{4}$ Relief and alienation fees were different from the corresponding incidents in England, ${ }^{5}$ and appear to have been much commoner, particularly the latter. Retrait lignager in the Norman villes seems to have been unique in respect to the narrow time-limit for the kinsmen's claim; in England and Germany such a claim might be deferred for a year and a day. ${ }^{6}$ Sale in need and other expedients for evading the kin's retrait seem to have been unknown in Norman towns. ${ }^{7}$

I Génestal, La Tenure en Bourgage, p. Io8. At Montivilliers, however, the rent of a masura was I Id. and each holder of a half-masura paid $5 \frac{1}{2} \mathrm{~d}$. (ibid., p. 103). M. Génestal was well aware of the contradictory charters given by Henry II of England, the one to Verneuil, the other to Pontorson (ibid., p. 106), but shows that, though in some villes (as Pontorson) each new burgage, formed by subdivision, must pay $\mathrm{z} 2 \mathrm{~d}$, the rule of the shilling rent for each masura, a rent never to be increased or lessened, was the custom of Normandy.

2 Ibid., p. 172.

${ }^{3}$ Ibid., p. I 39. Probably M. Génestal means the seventh degree of relationship according to Roman law. At tantalizing half-burghal Kingsthorpe the limit of kinship in respect to preëmption was the fourth degree (sec Glover, Kingsthorpiana, p. $4 \mathrm{r}$ ). This Germanic fourth is the same as the Roman seventh.

4 It seems unfortunate that no more is known of these older Norman illes. Probably the Inomesday scribes got the name 'masura' therefrom, though in Bayenx it could no more have been the artificial masura of the bourgs than it was in Bath.

3 See text, p. 54. In Formandy the fixed alienation fee was the exception, lods at antes of one-twelfth were the rule.

${ }^{6}$ In the period during which comparisons are of any value retrait in the Norman ailles was less than a day. Or is M. Génestal referring merely to the time-limit of court process? (See Northampton, p. 116.) liven as such, the interval seems small. He says nothing of year and day concerning this, but it seems as if the term must have been known to the tres ancien coulume of $c .1200$.

F ()r dees M. Génestal omit to mention them? Sale in need existed in boroughs in England having Norman customs. 
On the whole the tenure in Normandy was far less free and much more rigid than the tenure in England.

The tenure in the villes neuves of southern France resembled that of the Norman bourgs, except that it seems somewhat freer. Perhaps it is better to say that it resembled the tenure in created towns in general, common conditions having produced the same results everywhere in northern Europe. ${ }^{1}$ In the bastides rents were often separate for building-lot, garden, and land in the fields. ${ }^{2}$ Lods et ventes were apparently unknown. ${ }^{3}$

Like other Low Country institutions, urban tenure in the Netherlands was both early and rapid in development; but it differed little from burgage tenure in England. In the Flemish cities, particularly in Ghent, the land was the original tenement; at an early date it and the house thereon were often separately held. ${ }^{4} \quad$ Many areae or mansiones ${ }^{5}$ were allodial; some were held by rents, which seem often to have varied with the desirability of the tenement. ${ }^{6}$ The tenure in Ghent was heterogeneous, but the noble or episcopal lord often had his holdings in one block. During the eighty years preceding the first quarter of the twelfth century many a lord remitted the rents to his

1 Our authority for the bastides is A. Curie Seimbres's Essai sur les Bastides. Just as Edward I allowed the new burgesses of Overton to use his wood to build their houses, so we find the same right granted to the settlers of the bastides (Curie Seimbres, p. I55). Such houses must be built within a year, as a rule (ibid., p. I 70). Several examples of this privilege in England are given in Ballard, British Borough Charters, pp. 54-57.

E. A. Lewis, The Mediaeval Boroughs of Snowdonia, pp. 30, 6I, notes the parallelism between the bastides and the English garrison boroughs of North Wales.

2 See Curie Seimbres, Essai sur les Bastides, p. I67. At Grenade the rent of a lot was $5 \mathrm{~d}$., of a garden $3 \mathrm{~d}$., of an arpent of land Iod. At Arthez the maisons (i.e., lots) were 5 brasses by Io brasses (about $30 \mathrm{ft}$. by $60 \mathrm{ft}$.). At Gimont and Solomiac the maisons were 5 brasses by 14 brasses and the gardens a quarter-arpent each; the rent of a maison (or lot) was $6 \mathrm{~d}$., of a garden, $3 \mathrm{~d}$., of an arpent of land $\mathrm{r} 2 \mathrm{~d}$. The average frontage of a lot was 5 to 6 metres, its depth was variable.

3 Ibid., p. I 19.

4 Des Marez, Propriété Foncière en Flandre, p. 3.

5 The common term in the early period, when the lord's lands were filling up with merchants and handworkers, seems to have been one of these. See ibid., pp. 14, 89.

6 Ibid., p. I4: "secundum positionem mansionum suarum." 
burgesses.' During the early period there seems to have been much traffic in these allods by prescription and allods by grant. Then, through subdivision among a growing population, they were cut up into tenements, usually for a rent, small parts (still allodial) remaining as the possession of an aristocratic bourgeoisie. $^{2}$

Alienation fees had been due in some cities, mainly at sales of church-owned tenements; but the city of Ghent took these fees and added them to its registration charges. In some cities, as Arras, a fee for registration was charged which resembled strongly some of the enrolment fees in the Cinque Ports. ${ }^{3}$ This was merely a means of taxation, but may have been the revival of an old custom in the modern shape of a succession-duty. ${ }^{4}$ Rents were high and variable; shillings, not pence. ${ }^{5}$ Registration of deeds, when a tenement other than an allod was sold, was enforced through publicity. ${ }^{6}$ In one of the suburbs of Ghent, where the church was groundlord, the right to take a heriot lasted till the fifteenth century: it is doubtful whether this incident ever existed in the city proper. ${ }^{7}$ Relief also existed in some of the suburbs of the same city, more particularly those which had grown up on abbey lands; the usual amount was one year's rent of the tenement.s

In Ghent, as in some other continental cities, while the ownership of the land remained with the lord, the house was considered the property of its builder, and as such was a subject of commerce and of separate transfer. ${ }^{9}$ As in many English boroughs, there

1 Des Marez, Propriété Fonciere en Flundre, p. 23; between 1037 and 1120. This would virtually make such tenements allods. Ifouses in Ghent (ibid. p. 37) still bear the inscription of allodialism, "Free House, Free larth."

2 Ibid., Pl. $4450,152$.

3 Ibid., p. 100. The fee was fil. in the pound from the buyer and fil. from the seller when an inheritance was sold, a. 1358 .

4 This is unlikely, however, for even clerical exaction of alienation fecs had disappeared long before. See ibid. p. 100.

3 Ibid., Pl). $127-128$.

${ }^{6}$ Ibid., 1'. 155 .

7 Ibid.. p. 207. There was no mention of heriot in the charter of 1174 .

8 Ibid., p. 204.

"Ibid.. p. 231. Says M. Ines Marez, "the house is a movable," as much as "la bable et le's banes." Some houses seem to have been very movable when their 
was a limit beyond which a messuage might not lie fresh. ${ }^{1}$ Retrait lignager and retrait féodal, or what was left of them, were officially abolished at Ghent in the twelfth century; ${ }^{2}$ the former lasted longer in smaller cities, ${ }^{3}$ the latter was never known in the old city of Ghent. ${ }^{4}$ In the fourteenth century letting for short terms became common in the Flemish cities. ${ }^{5}$

The leading peculiarities of urban tenure in the Low Countries were its freedom from restriction, its precociousness, and its disorderliness. Though almost all the incidents which were features of urban tenure anywhere could be found in the cities of the Netherlands, they lay only on isolated tenements or blocks of tenements absorbed in the growing metropolitan area. ${ }^{6}$ Districts so annexed to the city sometimes brought their burdens with them, but did not long retain them; the retention of incidents lying on isolated tenements arose out of tenurial heterogeneity. The early disappearance of restrictions of all sorts in most of the Netherlandish towns was due to commerce and manufacturing, to the weakness of the counts of Flanders, and to usurpation of the rights of individual lords. Though in many respects such a city as Ghent was a virtual republic, and as far in advance of London as London of Carlisle, yet the tenures in the older Flemish and English cities resemble each other closely and far more than either resembles the tenure in the villes of Normandy. It does not, however, follow that either necessarily affected or influenced owners were fined if they took them out of the city (Saffelaere, in $\mathrm{r} 260$ ), especially at night.

Where the house was a chattel it is apparent that its alienation was not subject to the kin's retrait. I have found no instance in England where land and house were alienable in different degrees, though in London especially and in the latter middle ages, each or any part thereof might be separately transferred and separately held. Whatever the Flemish or Cologne view, in the English boroughs the mobility of inherited land, house, or rent was the same; each was governed by the rules of the kin's preëmption if the borough were one of restriction.

1 Des Marez, Propriêté Foncière en Flandre, p. 233. That is, a house must be built, or rebuilt, usually within a year.

2 Ibid., p. 247.

3 Ibid., p. 248. The limit was the usual year and day.

${ }^{4}$ See $i b i d .$, pp. $249^{-2} 5^{2}$.

5 Ibid., p. 255. Cf. London about the same period.

${ }^{6}$ See ibid., p. 295. The city of Ghent grew so rapidly that it overspread many districts where the dwellers owed feudal or villein service. 
the other. Whatever reciprocal influence there may have been was much more likely to have concerned burghal government and taxation, and to have been political rather than tenurial.

In Germany.' dealing first with the towns of the Upper Rhine, we find practically all the features of burgage tenure in England, though not always in the same degree. Rents were usually payable in money, though sometimes owed in kind. ${ }^{2}$ Traffic in perpetual rents out of houses was much greater in the commercial German cities than in the boroughs of agricultural England. ${ }^{3}$ During the early period such rent-selling needed the lord's consent. for the seller might overweight his tenement and so endanger the lord's service. Mortgages were the same as in England, mortgages of Germanic law. ${ }^{5}$

The kin's preëmption for inheritance was exactly the same as in England, and might be evaded by the same sale in need. ${ }^{6}$ Retrait fiodal was a very infrequent incident. ${ }^{7}$ In a few towns a fixed

I The authorities for what follows concerning the tenure in Germany will be Arnold's Geschichte des Figentums in den deutschen Städten, Keutgen's Deutsche Stadterfassung, and his Lrkunden zur städtischen Verfassungsgeschichte. Arnold's Geschichte des Eigentums centres on Basel, as Des Marez's Proprićté Fonciere en Flandre, on Ghent; Keutgen's Studterfassung, a somewhat polemical work dealing with town constitutions and origins, and his $L$ 'rkunden (for these see Introd., p. 8), a collection of town charters and customals (Stadirechte), are not limited to any particular region.

In the Appendix (pp). 191-208) there will be found a brief monograph on urban tenure in Germany, which is exclusive of what follows hereunder, and the material for which is obtained from the sources.

2 Arnold, Geschichte des Eigentums, p. 35. Hens were the favored medium (cf. Ledester, Southampton, etc.); pepper, doves, and cummin were frequent variations in the rent-service. See ibid., p. 1 ro.

${ }^{3}$ In an age when giving and taking interest lay under the church's ban. and when a burgher's tenement was the only security he had to offer, this method of getting capital (the loan being the principal, the rent the interest), often from the church itself, was constantly used.

+ Ibid. Il) 11.3 et seq. In many original documents quoted by I)r. Arnold appear the names of successive previous holders of a single tenement, as in the Rotuli

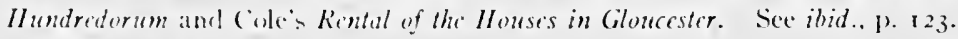

3 llid. lip. $125-127$.

"Ii an heir were under age his kin often consented for him, but the Sihoffen must approve and record this consent, which they sometimes refused to do, apparently suspecting the kin's bona fides. Ibid., p. 132 .

T Ibid., p. 154 . 
alienation fee, the Ehrschatz, was taken at sale, ${ }^{1}$ and concentration or accumulation of tenements in the hands of a few was as marked in the German towns as in the English boroughs. Copartners held, ${ }^{2}$ deeds were enrolled; ${ }^{3}$ a burgher's wife's dower, and joint consent to sale were as in England. ${ }^{4}$ Burgess-rights might be lost if a tenement shrank within a prescribed frontage; but there was no impediment on any sort of division. ${ }^{5}$ Not all these incidents existed in full force in any one town, and they never lay on all the tenements. The commonest incident in the regions of the upper Rhine valley seems to have been the fixed alienation fee; heriot and relief appear to have been unknown.

In Germany as a whole the kin's preëmption was very common. Its presence is not always directly stated in many of the Stadtrechte, but is implied in the distinction between purchase and inheritance, or in the year and day limit upon challenge by the kin, as at Spires,${ }^{6}$ Bremen,${ }^{7}$ Worms,${ }^{8}$ Augsburg, ${ }^{9}$ Freiburg, ${ }^{10}$ Berne, ${ }^{11}$ Hagenau, ${ }^{12}$ Soest, ${ }^{13}$ and Ratisbon. ${ }^{14}$ Inheritance might be sold everywhere, however, in necessity. Retrait féodal existed at Lübeck, an abbatial city. ${ }^{15}$

I Arnold. Geschichte des Eigentums, p. I 53: not for all tenements.

2 Ibid., p. I57. 3 Ibid., p. 165 .

4 Ibid., pp. 166-167.

5 Ibid., pp. I8I, I83. There was as much liberty as in London, and more license, in respect to division. Sometimes the boundary between two tenements was a stripe up and down or across the front of a house.

6 Keutgen, Urkunden zur städtischen Verfassungsgeschichte, p. I5, a. I I I I.

T Ibid., p. 19, a. I206. Possession for a year and a day gave one who had acquired 'aliquam hereditatem' under I eichbild the most favorable position as regards claim to the tenement. Though the term is much wider, one may translate Weichbild by urban tenure. It denotes the 'liberties' of the city.

8 Ibid., p. 57, a. 1023-25: 'hereditalis area.'

9 Ibid., p. 9I, a. $\mathrm{I}_{5} 6$. As in England the year and day began only when the heir came of age, or returned from abroad, and so on.

10 Ibid., pp. II7-IIS, a. II20. When a burgher died apparently kinless the ' conjuratores' held his inheritance a year and a day to allow a possible claim.

11 Ibid., p. I 29, a. I 2 I 8.

12 Ibid., p. 134. a. I164. An inheritance was held in suspenso as at Freiburg and Berne.

${ }^{13}$ Ibid., p. I42, a. I I 20- ?50. After undisturbed possession for a year and a day " de cetero sui warandus erit."

14 Ibid., p. 198, $a$. I 230. The limit of challenge there was unique, being ten years.

15 Ibid., p. 60, a. I182; for inheritance only. The would-be seller "primo abbati 
Heriot (Herwede, Heergewäte) was military in character, was not devisable, and went to a lord only when the burgher's death without male heir left no one else to inherit it, ${ }^{1}$ as at Bremen ${ }^{2}$ and Münster. ${ }^{3}$ Relief was owed by buyers as well as by heirs at Wetzlar; ${ }^{4}$ by the latter alone at Medebach. ${ }^{5}$ At times there were alienation fees, often the same in amount as relief. ${ }^{6}$ with which they were frequently confused. Wardship (by a lord), marriage, and homage seem to have been unknown. Fealty, in Cologne at least, was the same as in England. ${ }^{7}$

Original rents, as in England, were sometimes variable and sometimes the same for each tenement. ${ }^{8}$ As in England the rents of the older towns were low and variable; in some of these there were a few rents in terms of hens, as at Frankfort. ${ }^{9}$ These Arnold thinks were only symbolical hens in the later middle ages. ${ }^{10}$ Though financial obligations, as the Erbleihe, might lie on the domus and not on the area, ${ }^{11}$ unlike the Flemish usage the former seems not

aream suam cum edificiis que in ea construxit eodem pretio quo altero emenda sit offerat." Ci. Whitby, p. 54, n. 2.

The usuat term of the sources (Latin) for land is area; domus commonly means the house alone.

1 It consisted of the best war-horse, a sword, a spear, etc.

${ }^{2}$ Keutgen, L'rkunden zur stidtischen V'erfussungsgeschichte, p. 19. a. 1180. The Emperor held a childless burgher's Heraide a year and a day from his death, "sub expectatione legitimi heredis, qui illud hereditario jure debeat obtinere."

${ }^{3}$ Ibid., 1). 151, cir. a. 1221. "Ilereditats que dicitur herwede" night not be devised.

4 Ibid., p. 5o, a. I iso. It was zad., three times the rent of a tenement.

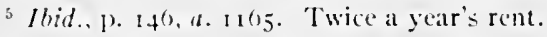

"Ihid.,p. 1+2. At Soest twice al year's rent. There was no relief. At Medebach (ibid, p. 1.46) the fee was the sane and must be paid at sale of "domum et septa" (cnclosures). Ileirs also patid. It will be noticed that these incielents exist only: in comparatively unimportant towns.

7 llid.. 1. 71, a. 1207 .

8 Thid.. 1. 59. a. 11 So. Wetdar, fl. from each ared; ibid., p. 1.37, a. 119.4-08,

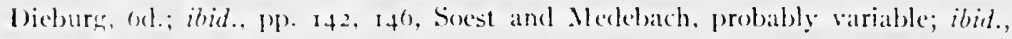
p. $150,2.11 .4,3.11$ :1mm, 41 .

9 Ibid. p. ino; only when owed from old time.

" Gersthiche des ligentums. 1). 35. These hen rents, on which . Irnold and other carlier writers laid of much stress as indicatine the domainial origin of urban tenure, br. Keutgen dismises with a few words: " Er erklärt sich einfach daraus, dass er in Zeiten, wo Jotermann Hiihner hielt. (ietd aber noch rar war, für die Meisten leichter zu cntrichten war" (Deutsche Situltierfassung. p. 120).

11 Keuteen. Deutsche Studterfassung, P1). $121-122$. 
to have been regarded as a chattel and therefore free from the kin's preëmption. ${ }^{1}$ With each tenement there was at times an assigned quantity of land in the fields, and gardens were occasionally given with the houses. ${ }^{2}$

Escheat in the great commercial cities was the community's, in smaller towns the lord's. In towns of the former class the tenement was commonly held a year and a day to await a claim by a kinsman; none appearing, it was sold, half the proceeds being applied pro anima sua and half for some useful purpose. ${ }^{3}$ Thus at Freiburg, ${ }^{4}$ Berne, ${ }^{5}$ and Hagenau ${ }^{6}$ escheats went to the city; at Hamm, ${ }^{7}$ Euskirchen, ${ }^{8}$ and in special cases at Vienna ${ }^{9}$ they went to the lord. Forfeiture, when it passed mere waste, seems often to have been to the city. ${ }^{10}$ In some cities, apparently proportionately fewer than in England, sale and less frequently devise were free, the kin's retrait having disappeared."

It is apparent that the customs of urban tenure in Germany shared the heterogeneity of German institutions in general, were

1 Thus at Worms in $1023-25$ " si [quis] domum in civitate vendiderit aream perdat" (Keutgen, Urkunden, p. 57).

${ }^{2}$ Ibid., p. 58, a. I 67 and I 178 ; at Berne in 1218 there were areas $100 \mathrm{ft}$. by $60 \mathrm{ft}$. (ibid., p. 126). Cf. the bastides, and the created boroughs of England.

3 Such as repair of the streets. At times the city got only a third, the rest was equally wasted on the civic authorities and the religiosi.

${ }^{4}$ Ibid., pp. I $17-1$ I 8, a. I 20.

5 Ibid., p. I33, a. I 218.

${ }^{6}$ Ibid., p. 134, a. I 64 . Seven fideles were the holders for the year and day.

7 Ibid., p. I50, a. I 213.

8 Ibid., p. 157, a. 1302.

${ }^{9}$ Ibid., p. $209, a$. I $22 \mathrm{I}$. The Archduke took any property if the heir would not live in Austria.

10 At Freiburg (ibid., pp. iг8-119) an escaped felon's house was torn down; after a year his heir might rebuild on paying a fine. At Constance failure to pay the original rent entailed forfeiture to the city (Keutgen, Deutsche Stadtverfassung, p. 125); this was reclamation for breach of contract rather than forfeiture.

11 Sale was free at Wetzlar in 1180 (Keutgen, Urkunden, p. 59); at Freiburg in I 78 (ibid., p. I 8 ) one might sell in necessity. The custom at the latter city was peculiar: his wife living, a burgher might sell "quidquid possidet"; his wife dead, only with his children's consent, which consent was not valid unless they were of age ( 12 years at Freiburg: in Germany usually 12 to 15 years). Sale, however, was allowed at any time on the seller's swearing that he had 'legitimam causam, (ibid., p. 120). At Berne in 1218 one might sell 'bona in allodiis' without let (ibid., p. 13I). At Cologne as early as 1180 devise was free for at least a part of the houses (Keutgen, Deutsche Stadtverfassung, p. 124). 
more varied than the tenurial customs in England and the Netherlands, and formed a contrast, as sharp as is possible in such an institution, to the artificial rigidity of the uniform Norman tenure. In some of the older cities especially, where there was much tenurial heterogeneity, the degree of freedom of transfer was not always the same for all tenements. ${ }^{1}$ In the created Städle, most of which were founded subsequent to the eleventh century, uniformity of tenurial customs was the rule, the only incident of the tenure being an infrequent Ehrschatz or a more infrequent lord's retrait. ${ }^{2}$

Of the four regions which have been taken as illustrative, the tenure, as a whole, was undoubtedly freest in Flanders and most restricted in Normandy, where rents were comparatively high, where alienation fees were frequent and heavy, where retrait lignager was ommipresent and unavoidable, and where, perhaps most important of all, there was no devise. The tenure in England is certainly likest to that in Germany; each has the same lights and shadows. The older German cities afford an exact parallel to such English cities as London and Oxford, where there was no tenurial burden whatever on most of the tenements and on a comparative few only the small fixed rent; while in both England and Germany, contemporary with these towns of tenurial freedom, there were boroughs or Städte where the lord was often in evidence. In Normandy at an early date the common law of

${ }^{1}$ Deutselie Shadtuerfussung, p. 1 26. Strasburg is I)r. Keutgen's most important example. Between 1285 and 1331 he instances transfers by the lord himself, with his consent, and without it.

It seems to me, however, that these transfers were of houses only and that the lord wat the lord of the ored or land. In bingland the land might have one lord and the hotise another; eath was a free tenement.

2 See for a summary of conditions in such towns Keutgen's Deutsche Shadterfassung.p. is . The rents were uniform in such a town.

He who is jamiliar with conditions in the boroughs is so accustomed to think of the fee-iarm rent in connection with feudal freedom in lingland that he may lowk for it in the larger ferman and Flemish cities. Ife will, however, lowk in vain. for a grant of the farm in fee securesl not tenurial but political freedom, which was so complete in the commercial cities of flanders and fermany (there is no need to bring the Free (itien into this comparions) that a grant of a fece-farm rent would have been only a gitt of part of what they alrealy hacl. 
the province settled the customs of the tenure in its villes. In Germany, England, and the Netherlands the older and more important towns or boroughs made their customs to suit themselves. ${ }^{1}$ Hence the early fixedness and homogeneity of Norman urban tenure; hence the variety and progress in tenurial customs elsewhere, and of these customs the most important and last to be adopted were free sale and free devise.

A comprehensive view of the urban landscape in our four illustrative regions causes minor differences to sink and fade; its most prominent feature, or lack of feature, is the uniformity of urban tenure everywhere in Teutonic lands, in lands where Teutons predominated, and even where they only ruled.' ' Giving of laws' there may have been, often not the freest laws. Commerce may have carried up Rhine or Thames many an idea sprung from Flemish civic legislation, but such ideas were far more likely to concern and affect town government than town land laws. Let each country have the credit of its own tenurial urban institutions, in which the same conditions produced almost the same results.

\section{CONCLUSION}

The boroughs in which the tenure was affected by incidents of feudalism or of feudal significance have been previously brought together. ${ }^{3}$ We shall now and in like manner summarize the boroughs where mobility lay under greater or lesser restriction and those where it was unfettered. ${ }^{4}$ Small fixed alienation fees were due the town at Norwich, Preston, Chesterfield, and Hereford. ${ }^{5}$ Fractional fees for registration were charged at Sandwich, Romney and probably all the Cinque Ports, Beverley, Northampton, and Maldon. ${ }^{6}$

1 Some of them had at times the lord's license to change a custom: it was usually needless. For Normandy see Génestal, La Tenure en Bourgage, pp. 235 et seq.

${ }^{2}$ One must not, however, look too sharply at Normandy. Our comparison does not include the Scandinavian lands.

3 See pp. $59 \mathrm{f}$.

4 The order of the following lists follows in general the order of treatment in the text.

5 See p. 127.

${ }^{6}$ Probably small charges for enrolling deeds were made in all important boroughs. 
The limitation of the kin's preëmption applied to sale in Cardiff, Tewkesbury, Preston, Pembroke, Wearmouth, Northampton, Bury Saint Edmunds, Portsmouth, Dover, Romney, and probably all the Cinque Ports, Nottingham, Derby, Manchester, Stockport, Salford. Newcastle, Lincoln, York, Beverley, Dunwich, Ipswich, Bath, Morpeth, Woodstock, Alnwick, and all the Bretollian boroughs of Ireland, as Drogheda and Inistiogue. ${ }^{1}$

Devise of either sort of realty was unknown in the Bretollian boroughs of Ireland and in Barnstaple, Cardiff, and Tewkesbury, ${ }^{2}$ and was allowed only when there was no heir at Manchester, Stockport, and Salford. Devise was allowed for purchase and forbidden for inheritance at Norwich, Newcastle, Nottingham, Ipswich, Yarmouth, Colchester, Shrewsbury, Rhuddlan, Bury Saint Edmunds, ${ }^{3}$ Dunwich, Southampton, Portsmouth, and probably at Melcombe Regis and Weymouth and also all the Cinque Ports. ${ }^{4}$

Sale was free at Gloucester, Leicester, Winchester, Lynn, Bridport, London, Bristol, Oxford, Congleton, possibly at Leeds and Pontefract, Castle Rising, Chard, Hull, Wycombe, Altringham, Rhuddlan, Dublin, Cork, Limerick, Waterford, Rathcool, Hereford, Cambridge, Norwich, and Scarborough. ${ }^{5}$

Devise was free at London, Oxford, York, Newcastle, Congleton (probably), Wycombe, Hereford, Bakewell, Hull, Chard. Scarborough, Altringham, Bridgnorth (possibly), Berwick, Canterbury, Cambridge, Lynn, Bristol, Dublin, Waterford, Limerick, Cork, Rathcool, Hedon, and possibly at Bath at the close of the merliaeval period. ${ }^{6}$

A comparison of these lists with those of towns affected to any extent by feudal incidents ${ }^{7}$ will make it plain that the boroughs of greatest tenurial freedom are the boroughs of the low and commonly variable landgable, those whose history began and

\footnotetext{
1 See Restricted Sale, pp. 114-126.

2 Ancl probably other boroughs in England having Norman customs.

3 Where one-half an inheritance might be willed.

4 See Restricted Inevise, pl. 135-144.

5 See Free Sale, pp. 1 10-1 14.

- See line bevise, pp. 130-135.

7 See pP. 59 i.
} 
whose tenure was established before the Franco-Norman invasion from over the narrow sea.

Such was burgage tenure in England in the middle ages; a tenure which in the older boroughs had no feature of feudalism, except that its theory of land-holding was possession and not ownership. The burgess and the nobleman held each of some lord; if of no one else, then of the king. In most boroughs, however, the payment of the landgable was the only mark of this feudal obligation, ${ }^{1}$ while, as the borough grew, the number of tenements owing this rent, and the value of the rent itself, became relatively so small that in some towns at least it ceased to be paid at all. For those, and those only, who paid the landgable there was a slight feudal tinge in the tenure. However, the boroughs created by bishops and barons ${ }^{2}$ often received their tenure burdened with a few of the feudal incidents, as relief and alienation fees.

Where the common law most concerned the boroughs, that is, on the criminal side, it was compelled to recognize the facts rather than the theory of burgage tenure. ${ }^{3}$ In the country at large the possessor was but a holder; a felon's tenement, save for treason, was subject only to year, day, and waste. In the greater boroughs a felon's tenement was forfeited to the king; the possessor was an owner in regard to the law, in fact though not in form.

Yet all through the middle ages the tenurial flexibility of the boroughs had no effect on the tenurial rigidity of the country, as far as the law was concerned. The act of I290, known as Quia Emptores, might recognize the validity of sale, but those who tried to devise land were met by the decision that burgage

1 Except the oath of fealty sworn by land-holders and non-landholders alike in the middle ages. Even payment of the landgable, which was collected by elected bailiffs in the larger towns, was very impersonal.

2 The king was not a creator of boroughs, Hull and Overton excepted.

3 Tenements in the boroughs were held under customary law, subordinate to (in that pleas of land might be appealed to the king's court on error or for default of judgment) rather than a part of the common law. In such cases the law was declared by a jury of burgesses before the royal justices. The Year Books and Plac. Westmon. Abbr. afford illustrations. See text, p. I13, note 6 et pass. 
tenure obtained in boroughs alone, and under this tenure only might land be devised. ${ }^{2}$ The personal and political effects of holding under a tenure where incidents of feudalism fell seldom and those of villeinage never, and where a feudal lord was seldom or never in evidence, may hardly be estimated. Yet though the mediaeval English burgher, to judge from court leet records, seems to have been often independent to the point of unruliness, except on rare occasions he cannot be said to have taken a notable part in happenings beyond the bounds of his borough, while his leading role in national events was mainly that of a subject for taxation.

When in 1540 the Statute of Wills freed the feudal tenure in part and the socage tenure in whole, when the customary land law of the older boroughs had become the common law of England, probably some backward boroughs were still retaining the old Germanic custom of the kin's retrait, though at that time it could have been little more than a nominal impediment to mobility, except in so far as it affected devise. From 1645 , when the Long Parliament abolished the feudal tenure with its incidents, ${ }^{2}$ burgage tenure ceased to be distinctive. ${ }^{3}$ After that date the only importance of holding a tenement which paid a chief rent lay in the fact that in some boroughs its holler might vote in Parliamentary elections. The Reform Bill of 1832 and the Municipal Corporations $A$ ct of I $\delta_{35}$ virtually ended the burgages with whatever they stool for; only enough to entail a rote had commonly retained the name, and even that was worthless now. $A$ few chief tenements remain, ats at (ambridge and Doncaster,"

1 Coke, Commentary upon Lillleton, sec. r rob. Sce Elton, Tenures of Kent, pp. 156-157. The term burgage was sometimes used outside a borough, but in such a case the common law considered the tenure as secage. This did bot apply to a part of a borough which had become detached from the main borough.

There wats a period in IIenry. III's reign when it appeared ats the land law were about to recognize devise of realty held under both feudal and socage tenures, but the older opinion specedily reasserted itself.

2 Reennacted in sofo, the former passage having been held null.

${ }^{3}$ Except in so far as some rural boroughs, Ruthin for instance, retained relief or heriot.

- At leats this was the case in $1 \$ f^{2}$ and $1 S 87$ respectively, the dates of publication of cooper's and Tomlinson's llistories. See text, pp. 13, 157, n. 2. 
but their glory has departed and therewith their meaning. ${ }^{1}$ Our subject, however, ended with the middle ages; the full development of burgage tenure was reached before their close. Its later history is of interest mainly to the student of the Parliamentary franchise, and its survival until our own day to the antiquarian.

${ }^{1}$ Unlike heriot on copyhold lands, a very living institution. 



\section{APPENDIX}





\section{APPENDIX}

\section{URBAN TENURE IN GERMANY}

In the text ${ }^{1}$ it has been shown by a fairly numerous list of illustrations that urban tenure in England was best comparable with that in Germany. In the following pages a somewhat more extensive description of the conditions under which real property was held in the German cities will be essayed. No pretence, however, will be made of having exhausted the subject or of having gone deeply into detail, for an attempt to do either would undoubtedly lead to failure, partly because of the lack of sources ${ }^{2}$ within reach, but mainly on account of the scope and comprehensiveness of this or indeed any subject relative to that unfortuitous concourse of sovereign states known as mediaeval Germany. ${ }^{3}$

In addition, what was previously stated concerning a few of the authors of modern English works on burghal institutions, that they have already a fair idea of some of the main features of urban tenure, ${ }^{4}$ is true to a much greater extent of the German writers on this subject. This may be the chief reason why these German writers on municipal origins have taken so much for granted in respect to familiarity with urban tenure on the part of their readers. To us, however, it seems more profitable to try to tell what $W$ eichbild ${ }^{5}$ really was than to waste time in further discussion of the question of its origin, a question now fairly well settled in favor of the advocates of a free as opposed to the maintainers of a domainial beginning.

1 See pp. $178-183$.

2 The sketch in the text above (pp. 178-182) on the urban tenure in Germany is taken mainly from the sources; but these had been already collected by Dr. Keutgen. task.

${ }^{3}$ To this must be added a personal sense of inability to perform such a huge

4 See pp. 3-6.

5 As before stated, this term is much wider in scope than urban tenure; it means all the peculiar customs in vogue within the urban jurisdiction, the tenure being one of these. 
The secondary literature which is more or less relevant to our subject has already been briefly described; ${ }^{1}$ the source material germane thereto follows to a great extent the same lines as that bearing on the tenure in England. One kind of source material however is, of course, almost completely lacking, that which is contained in the records of a strong and all-pervading central government. If, therefore, there cannot be found much material in respect to a town in its own or other local archives, such is not likely to be found anywhere. The subject-matter for this short essay has been obtained largely from German local histories and collections of town records. The former differ from their prototypes in England in that they are written as a rule by more scholarly men, though the sketchy superficial town history is no stranger on library shelves even in Germany; the latter are nearly always ably edited. ${ }^{2}$ In addition to these local histories and town records, as well as other sources which will appear in the footnotes, much information can be obtained from Heinrich Gottfried Gengler's Deutsche Stadtrechts-Alterthiimer (Erlangen, I 882), and particularly from Deutsche Stadtrechte des Mittelalters (new ed., Nuremberg, I866), by the same author, and a small amount from the first and third volumes of Georg Ludwig von Maurer's Geschichte der Städteverfassung in Deutschland (Erlangen, I869-7 I).

In the following brief description of the tenure the order of treatment will be in general that used in the text; first the feudal names and feudal features, and next the degree of mobility in sale or devise or any manner of alienation. It should not be overlooked that the rigidity or flexibility of the town land law was, as in England, a matter which lay with the burghers themselves. ${ }^{3}$

1 See pr). 7 f.

2 With no invidious motive it seems fitting to mention with highest praise the Lrkundenbuch der Stadt Strassturg (Strasburg, 1879-1900, 7 vols.) as illustrative of careful and able editing. The editor of the third volume, Privutrechtiche l rkunden und Amtstisten iom 1266 bis 13,32 (1884), which is quoted below, is I)r. Aloys Sehulte, whose introduction also is unexcelled.

Sometimes, however, the English local historian's stupiedity is more profitable to an investigator than the (ierman historian's perspicacity, the former often publishing material which he neither understands nor incorporates, and which often has no learing on his theme, but which a student of municipal institutions frequently finds of value.

3 () rents and values of realty in the German towns so much has been written during the last half century that this feature will be omitted here, except for a brief discussion of original rents. 


\section{The Incidents of Weichbild}

Had tenements held under Weichbild been subject to the aids, the well-known warlike character of the German aristocracy would surely have caused some trace to be left of the aid for knighting or for ransom; at least a demand for such would probably have been recorded in town archives; but in Germany as in England ${ }^{1}$ the aids seem to have been so completely unknown that the Stadtrechte did not even chronicle exemption.

In respect to marriage the case is slightly different, not that urban tenure was subject to this incident, but that the burghers' ${ }^{2}$ freedom therefrom was sometimes made a matter of record, as at Vienna, Munich, ${ }^{3}$ and a few other towns. As in England, the Stadtrechte of the larger towns ignored the matter. ${ }^{4}$

Feudal Wardship, the natural concomitant of marriage, was likewise unknown, for the German towns had a custom of their own, which, like the corresponding burghal custom in England, might vary as to minor matters in different towns. ${ }^{5}$

Relief was a comparatively infrequent incident, small in amount, and often remitted to direct heirs. This incident, found in created towns only as a rule, is seldom mentioned in the Stadtrechte.

Heriot was a much commoner incident in German towns than in English boroughs. It was never confused with relief, after the fashion of Manchester and a few other places where the heriot existed in England. In the Städte heriot was never the best chattel which the lord took from his villein, but was even more military in scope, though not in nature, than the sword or lance which was the usual English rendering. ${ }^{6} \quad$ The heriot of the German city was nearly always some

1 Castle Rising excepted.

2 The burgher was a freeholder. Tenants at will or for years were not burghers. See W. Arnold, Verfassungsgeschichte der deutschen Freistädte (Hamburg, etc., I 854), pp. 240 et seq.

${ }^{3}$ Von Maurer, Geschichte der Städteverfassung, i, p. 390.

${ }^{4}$ In some Stadirechte there are sections which state that marriage is free or is not free. This does not refer to any incident but only to the effect which a Bürgerin's marriage with a 'foreigner' may have on her civic standing; it may also refer to unequal marriage within the town. At Vienna and Heimburg, for instance, a Bürgerin who married a king's official or a knight lost her 'Freiheit und Vermögen.' In the later middle ages this rule fell into disuse. See von Maurer, Geschichte dcr Siädteverfassung, i, pp. 389-39o.

5 See Arnold, Geschichte des Eigentums, p. I32 et pass.

6 Some of the charters state that there shall be no heriot in the base sense. See von Maurer, Geschichte der Städtererfassung, i, p. 39r; Gengler, Deutsche Stadt- 
sort of arms; horses were included, sometimes best horses, though not in the best head sense. The Hervede, ${ }^{1}$ which recurs so often in the Stadtrechte, was always warlike in nature, but its destination varied in time and place. At an early period this payment of arms and horses at a burgher's death went to the lord of the town. He might and often did grant his right to the burghers. ${ }^{2}$ However the towns got it, whether by grant or usurpation, after the thirteenth century no lord might take heriot. The incident itself remained unchanged in nature, but became that portion of an inheritance which must go to the direct heir, if he lived within the town, and was a matter whose regulation lay within the townsmen's jurisdiction: in this sense it was a restriction on devise of chattels rather than an incident of the tenure. In the last stage the custom was abolished or became meaningless; ${ }^{3}$ its significance ceased as commerce grew and military needs decreased.

In a small number of cities, the Stadtrechte or the charters do not state that heriot was not rendered to a lord. Such is the case at Ülzen, ${ }^{4}$ Verden, ${ }^{5}$ Werl, ${ }^{6}$ Wernigerode, ${ }^{7}$ Medebach, ${ }^{8}$ Grossen-Salze, ${ }^{9}$ Prenzlau, ${ }^{10}$ and other towns of about the same relative importance, and originally more or less of the nature of garrisons." In some towns the lord could get his arms and horses only when there were no heirs." Commonly the claims of extra-burghal heirs must give place to those

rechle, p. 206. In a town (Studt) raised from the status of a village (Dorf) the charter commonly stated that heriot in the sense of 'best head' or 'best chattel' was thereby abolished.

1 Hergeatithe und Gerade (Gerathe, Rathe, etc.), the latter a contribution of clothing by a Burgerin, were of ten coupled.

2 As at cösfeld, where the kord, who was bishop of Münster, gave the right to take heriot to the townsmen: Franz I)arpe, Coesfelder Lrkundenbuch (Cösfeld, $1000-0.8), \mathrm{i}, \mathrm{p} \cdot 30$, a. 1306.

3 Von Maurer, Geschichte der Städtewerfassung, i, p. 427.

4 (iengler, Deutsche Studtrechte, 1). 497, a. 1270.

'Ibid., 1). 508, a. 1330.

${ }^{6}$ Ibid.. p. 520 , a. $134^{\text {f). }}$

7 Ibid., p. 521 .

"Ibid.. P. 286 . Heriot was less military here than in most towns. There was relief alsor.

Ibid., [1. 17.3. a. 1473 .

10 lbid., [1. 301, a. 1.4 to.

$"$ See ibid., p. 394, Salzwedel; ibid., p. 343, Parchim, 4. 1218 (Iferaede and IIberade); ibid., P. 270. Lüneburg; Lünen (in the 'Red Book '), 1). 272; Ilerferd, p. 195; Hiorde, p. 109; Stendal, p. tho.

12 Escheat of chattels as it were. 
of heirs within the town. ${ }^{1}$ Many places agreed only in making no provision in the lord's favor; the ultimate destination of the heriot was variable, as at Stade, ${ }^{2}$ Ingolstadt, ${ }^{3}$ Naumburg, ${ }^{4}$ Dresden, ${ }^{5}$ Cleves, ${ }^{6}$ and Hanover. ${ }^{7}$

From these examples heriot seems to have been a commoner incident in the German cities than in the English boroughs, and, while the same in nature and origin, to have undergone greater change, ceasing to be taken by a lord, but remaining long as an inalienable and undevisable chattel, and therefore almost constituting a part of the tenement. ${ }^{8}$ Cösfeld affords an illustration of what probably happened in many small towns; the lord resigned his right to heriot to the burghers, who did not abolish the incident, but at once added a clause to their Stadtrecht forbidding separation of Herwede and tenement. In Germany as in England, the military character of heriot and its antiquity show its connection with free and ante-feudal tenure. ${ }^{9}$

Escheat. As would be expected, this incident was subject to more varying conditions in German than in English cities, on account of the greater degree of autonomy attained by many of the former. At an early period, and in many towns all through our period, escheat was probably the lord's undisputed prerogative. When, however, the age of written records began, whatever the course of escheat may once have been it did not run lordward. Von Maurer is no doubt quite

1 At Schwaney to wit the Stadtrecht provided that Herwede 'shall be given to no one outside the town as long as any one of the blood shall be left within the town.' If no intra-burghal heir appeared the Herwedc was held subject to any heir's claim for a year and six weeks. In the absence of any claim it went to the lord (Gengler, Deutsche Stadtrechte, p. 420), probably the lord of the tenement, who, in small created towns, was usually the lord of the town.

2 Gengler, Stadtrechtc, p. 457.

3 Ibid., p. 214. None but a dweller in the town might take heriot.

${ }^{4}$ Ibid., p. 3IO. No burgher might take heriot. Who might then ? The lord of the town?

${ }^{5}$ Otto Richter, Verfassungs- und Verwaltungsgeschichte der Stadt Dresden (Dresden, I885-9I), i, p. 315: " hergewette . . . sall yn der stat bleiben."

${ }^{6}$ Gengler, Stadtrcchte, p. 64: heriot must remain with the tenement. The same rule held at Cösfeld.

7 Ibid., p. 187: same custom as at Naumburg.

8 That heriot seems to have been considered almost inseparable from the tenement is shown by the custom at Brakel where "herwede und gerade, wenner de bynnen Brakell verfallen, und neen erue uth der rechten linien dartho nagelaten weret . . . herwede und gerade nicht de Rait [Rat] to Brakell, sunder der neyste erue van dem blode hebben" (Gengler, Stadtrechte, p. 35).

- Or rather its origin in a period before the systemization of feudalism. 
right in stating that this incident was the lord's till the towns gained the right thereto. ${ }^{1}$

In towns of the older custom, where escheat was the lord's, Lippstadt and Cleves illustrate the usual procedure. The town council held the tenement a year and a day ${ }^{2}$ to await an heir. If one did not appear, the property went to the lord. ${ }^{3}$ At Schwerin escheat was apparently the lord's when there failed an heir within the seventh degree. ${ }^{4}$ At Freiburg-im-Breisgau the lord had only part of an escheat: he (the duke) retained a third, the poor and the city divided the rest equally. ${ }^{5}$ At Grech an escheat was shared equally by the city, the poor, and the religiosi; ${ }^{6}$ at Padberg it lay with the town council to say whether the city, the poor, or the religiosi should have the whole escheat. ${ }^{7}$

Forfeiture. The custom in respect to forfeiture was even more variable than that regarding escheat. At Holzminden the house of a felon who had fled might go to his heirs if his defalcation or the damage he had done were made good; at times the court might decide that no such compensation need be made. ${ }^{8}$ At Wesel no citizen's heredity might be 'wasted' for any crime; ${ }^{9}$ at Padberg, whether a

1 Geschichte der Städtczerfassung, iii, pp. 367-308.

2 And the $I / c r i c d e$ (if such existed) joined thereto a year and six weeks.

${ }^{3}$ Gengler. Stadirechte. pp. 256 and 64 . This was much the same as the English procedure.

4 See ibid., p. 433, a. 1224. The tenement was held the usual year and day. No heir appearing, " mit sovener Hand wedderum werden verreket."

At l'fullendorf in 1220 there was what may be called escheat for breach of contract; the lord took his area from him who would not build thereon within a specified time, usually a year from St. Michael's (September 29). At Altenburg in 1256 he who let his land lie fresh $($ deserlam) a year and a day lost it to the lord (Cicngler, Stadirechte, pp. 356-357).

5 E. T. Gaupp, Über Deutsche Städtegriunding, Stadterfassung, und Hichbild im Mittelolter (Jena, 1824), 1p). 204, 39.3. See also (iengler, Stadtrechte, p. 125. This was early in the twelfth century; the duke may later have lost his share.

6 (iengler, Studtrechte, p. г ;0, a. 1 $2 \$^{2}$.

7 Ibid., P. 34 I, a. 1200 .

At Biclefeld and at Rheda a tenement which had come to a lord, probably by way of escheat, must be sold to a townsman within a year and a day (von Maurer, Geschichte der Städteierfassung, i, p. 392). The same compulsory sale within the same period existed at Frankfort for tenements which had been obtained as 'Seelgerette " (ibid., i, p. 400, a. 1318 ).

8 (iengler, Stadtrechte, p. 206, a. 1 245. In other circumstances it seems that a felon's tenement was sold and the proceeds used to pay for the damage he had done.

9 Ibid., p. 523, a. 1277. 
felon fled or was hanged, the heir received his tenement. ${ }^{1}$ At Ratisbon in the eleventh century and at Freiburg-im-Breisgau ${ }^{2}$ a felon's house was torn down; at the latter city his heir might rebuild after a year had passed on payment of $6 \mathrm{~d}$. to the lord of the city. At Breisach a fleeing felon's house was wasted and all his chattels went to the Emperor; his heir might rebuild after the lapse of a year on payment of three pounds to the judges and ten pounds to the Emperor. ${ }^{3}$ At Strasburg waste was the same, but the city took the forfeiture, though this might be avoided if the felon could pay an amend and also make compensation. ${ }^{4}$ The courses of escheat and forfeiture in the German towns show well how the absence of a strong central government affected the tenure. In England the king usurped the rights of other lords to forfeiture and often to escheat. In Germany the towns, if the smaller places be excluded, acted as the English king; they commonly controlled forfeiture and often took escheats.

Fealty. In a few of the German cities this incident was a little more complicated than in the English boroughs. As a rule, however, the burgess and the Bürger took the same sort of oath; each swore to be faithful to the lord of the borough or Städt and to its customs. ${ }^{5}$ At Dattenried the burghers swore fealty to the king and the abbot, ${ }^{6}$ at Passau the burgess-oath might have been taken, so like is it, from an English customal; ${ }^{7}$ at Kahla the burghers swore fealty to the lord, who in turn swore confirmation of the town privileges. ${ }^{8}$ At Selz fealty was owed to the abbot, at Gehrden to the praepositus, ${ }^{9}$ at Brakel

1 Gengler, Stadirechte, p. 34I, a. I 298.

At Minden, if 'bona' included the tenement, the rule was the same in the latter contingency: "si aliquis [burgensis] furatur et suspenditur, ejus uxor et sui pueri . . . bona sua integraliter obtinebunt." R. Doebner, Die Städtepriviligien Herzog Otto des Kindes (Hanover, I882), p. 32, a. 1300.

2 Gengler, Stadtrechte, p. I 26.

3 Ibid., p. 42 , a. 1275 .

4 Georg Winter, Geschichte des Rathes in Strassburg (Breslau, 1878), p. $4 \mathbf{1}$. Most of these records refer to an abjuring felon's tenements.

${ }^{5}$ In some of the German cities the oath was to the king, the lord, and the town. In the boroughs the oath was to the lord of the town and the town itself. As the king was lord of all the important boroughs fealty was thus usually due to the king and the town. See von Maurer, Geschichte der Städteverfassung, iii, pp. 368-369, in respect to this oath to be faithful to the king as head of the state (or as the state) and to the lord of the city.

${ }^{6}$ Gengler, Stadtrechte, p. 78 .

7 Alexander Erhard, Geschichte der Stadt Passau (Passau, 1862), i, p. I76.

${ }^{8}$ H. Bergner, Urkunden sur Geschichte der Stadt Kahla (Kahla, 1899), pp. 21-22, a. 1431 .

9 As the lord's deputy? 
to the lord of the town. ${ }^{1}$ At Cologne the burgomasters swore a sort of fealty in a peculiar way; one burgomaster put the oath to the other, who took it in the name of the council and the community. ${ }^{2}$ On the whole burghal fealty in Germany was much the same as in England, a burgess-oath and not a feudal obligation.

Retrait Féodal existed in a small number of towns, most of which were abbatial, though in some instances it affected the alienation of only a few of the tenements, as at Strasburg. ${ }^{3}$ At Würzburg there were many sales where the abbot and monks not only had the right of preëmption but the right of consent to alienation as well. ${ }^{4}$ In a few towns the lord's consent to sale seems to have been necessary in all cases; this was the condition at Kahla even as late as the fifteenth century. ${ }^{5}$ At Rappoltstein in Alsace transfers were made with the lord's consent, which he seems never to have withheld, and even through the lord as an intermediary; his services were gratuitous. ${ }^{6}$

1 Von Maurer, Städtetcrfassung, iii, p. 280. At Bregenz "die Bürger . . . musste ihren Grundherrn schwören," at Basel all who held tenements paying original rents (zinspflichtige) must swear fealty to the lords to whom such rents were due (ihrem Lehens- oder Zinsherrn huldigen). If this were the case others than the lord of the town (at Basel the abbot was lord) must have received fealty. It seems odd that Arnold in his exhaustive Geschichte des Eigentums should have omitted to note this; if true, burghers must often have sworn fealty to each other, a meaningless performance. Such a procecding would have more significance if the chief lord of a tenement were an aristocratic burghal holder or groundlord.

2 Von Maurer, Geschichte der Städtecerfassung, iii, P. 464. This fealty to the archbishop of Cologne was sworn in much the same way as feally at Weymouth, whose Jord was the prior of St. Swithin's at Winchester (see P. 47 alwove). In (atch case it was rather the taking of an oath of office than swearing burghal iealy, which at Cologne existed side by side therewith (see Keutgen, Crkunden, H. . $\mathrm{I}$ ).

3 Crkundenbuch der Stadt Strassburg, i, p. 459, a. 1200. See also ibid., iii, introd., p. xlii, where this preimption by a lord is noted and stated not to have been a city custom.

4 S. Rictschel, in Zeitschrift der Savigny-Stifung für Rechtsgeschichte, xxii, p. 222. In most of the recorded instances of sale, however, there is no word of permision.

Many cases can be guoted of sale with a lord's, that is a superior holder's. consent. These, however, are only instances of transfer where an option on a tenement has becen inserterl ats a clasuse in a contract. In fact such cases prove not the presence but the alsence of the lorel's right to first purchase.

5 H. Bergner. I rkunden zur Geschichte der Stadt Kahla, pl]. 22, 28, 32. Frederick and Sigmund, dukes of Sixony, lorels of the town, often figure in the records as consenting to sales of tenements.

" Karl Allurecht, Roppollsteinisches L"rkundenbuch ((o)mar, isc)1-08), i, p. 40r et pass. The usual entry runs " . . . cin bürger . . . und . . sin eliche wirtin ... bezeichnen... Ilerrn von ter Oberstadt (or der Niederstadt) als Siegler 
It appears, therefore, that retrait féodal in Germany was the same as in England, an infrequent incident due sometimes to the lord of the town and sometimes to the lord of the fee.

In some of the created German cities, as Hagenau, there was a modified form of gitte, which, however, no ordinary lord might demand. The Emperor had the right to quarters for himself and his retinue when passing through the city, but there must be no detriment done the citizens. ${ }^{1}$

The foregoing evidence, which, though scanty, is fairly representative, shows that the tenure in the cities of Germany was affected by the feudal incidents in nearly the same proportion as the tenure in the boroughs of England, the only important variation being the destination of escheats and forfeitures in some of the greater German cities. In Germany as in England what little of feudalism there was is found chiefly in the smaller and created cities; the disabilities under which the tenure in the larger cities sometimes lay were imposed by the citizens themselves.

\section{GRound RENTS}

In respect to ground rents figures are not so easily obtainable as in England. As in every country in feudal Europe, there were towns whose free tenure no charter created and towns where free tenure was a gift from some lord. Of those of the latter sort some may have been raised, or have raised themselves, from a state of unfreedom, and many were founded as garrison towns. ${ }^{2}$ In the cities of the last class the 'areas' were equal and bore equal rents: each area was commonly accompanied by a varying quantity of land in the common fields, ${ }^{3}$ whose rent was sometimes included in the rent of the area,

der Urkunde, durch welche sie erklären," etc. Viewed in another way this was only a means of securing registration of deeds.

1 K. W. Nitzsch, Ministerialität und Bürgerthum im II. und 12. Jahrhundert (Leipsic, 1859), p. 328. King Philip renounced this privilege at Spires (ibid., p. 334).

Of base or villein service there is no trace, except that at a very early period many of the burghers of Strasburg were required to work a few days in the year for the lord; a certain number of each trade or handicraft were exempted (H. H. T. Horn, Die Anfänge der Strassburger Stadtverfassung (Rostock, I868), p. 34, note 3). Possibly a few other towns once had the same custom. Cf. Hereford, T. R. E.

2 In Germany this founding of free cities or towns was very much earlier than in Wales and in Ireland.

${ }^{3}$ Cf. the IVelsh and Irish boroughs. See pp. 96, n. 3, 99. 
and sometimes separate from it.' In the older towns the ground rent was variable, as in England and the Netherlands. In towns of creation it was the same for each tenement and was commonly a shilling or some fraction thereof, as in Normandy and Ireland. Whether variable or uniform this rent lay on the ground alone. This was originally the case in many of the English boroughs, but there land and house became connected in nature; both might be, and commonly were transferred as a unit. In the German cities when land and house were transferred to the same person each was usually specified, ${ }^{2}$ and in the older cities each of ten had its own low quit-rent or fee-farm rent. $^{3}$

16 d. an acre at Warburg (F. Philippi, Zur Verfassungsgeschichte der westfälischen Bischofsstädte, p. 37, note 82); 2d. at Padberg (Gengler, Stadtrechte, p. 340).

2 For instance, at Ulm in 1285 there was a grant of a house, which paid a pound of wax, and an "aream subjacentem" which paid a pound of pennies and four hens (F. Pressel, Llmisches Lrkundenbuch, i, p. 182).

3 Original rents in some of the German cities were:

Erfurt, 2 d. (E. M. Lambert, Die ältere Geschichte und Verfassung der Stadt Erfurt, p. $122, a .1256$ ).

Freiburg-im-Breisgau, I 2d. (E. T. Gaupp, Deulsche Städlegrïnding, pp. 192, 388).

Garz, $\frac{1}{8}$ mark silver (Freiderich von Dreger, Codex Pomeraniae Diplomalicus (Berlin, 1 768 ), p. 199, a. 1240).

Grevenmachern, r4d. and a capon at Christmas (Gengler, Stadtrechte, p. r7 I, a. 1252 ).

Halle, 6d. (Gaupp, Deutsche Städtegrïndung, p. 192, note 19).

Hamm, 4d. (Gengler, Stadirechte, p. 185, a.1213).

Holzhagen, 12d. (Codex Pom. Dipl., p. 461, a. 1262): "de quolibet manso unum solidum denariorum."

Königsberg, about 8 mark (M. Perlbach, Quellen-Beiträge zur Geschichte der Stadt Königsberg im Mittelalter (Göttingen, 1878), p. 2, a. 1299); the rent was a lalf-ferto (ferto, or fertol $=1$ mark) for each virgo $(261 \mathrm{ft}$.) in width of an area 4 iirgas long; an area longer than this paid a ferto for each virga of width.

Münster, a. $117 \mathrm{~S}, 5 \frac{1}{2} \mathrm{~d}$. for each area (F. Jhilippi, Zur Verfassungsgeschichte der westfalische Bischofsstädle, p. 20). This rent was neither increased nor lessened on account of division or new houses; $1 /$ ansio there often meant house (Gengler, Stadtrechte, ?. 37\%).

Parlberg, ocl. and one 'pullus' for each area and 3 d. for each half-area (Cengler, Stadtrechte. P. 340, a. 1290).

Prenzlau, ${ }_{3}^{1}$ mark (Codex Pom. Dipl., p. 167): "de quovis manso ferto dimiclius."

Stargard, is mark silver (ibid., p. 240, a. 1243): the rent of each 'mansus' was 'tres lutunes argenti, one loto $={ }_{16}^{1}$ mark silver, about a shilling.

Llm, 12 d. (Gengler, Stadtrechte, p. 503, a. 1296): if the lord neither came nor sent for this rent on the day it fell due it need not be paid for that year. (For rents not original at $\mathrm{Ulm}$ see $\mathrm{F}$. Pressel, Clmisches Lrkundenbuch, i, p. ${ }_{57}$, a. $1279^{-S 0}$.) 
Most of these rents of areas or of houses disappeared in process of time, as their insignificance made them not worth collecting. As there was not the same political value attached to original rents in the German cities as in some of the English boroughs their lapse was even earlier in Germany than in England. A few still remain, ${ }^{1}$ though even they may soon be overborne and trampled in material dust by the march of modern German industrialism.

\section{MOBILITY}

Alienation fees in the German cities were much the same as those in the English boroughs. They were usually low, varied from place to place, and were paid sometimes to a lord, but oftener to the community through its officials. ${ }^{2}$ At Strasburg the alienation fee, ${ }^{3}$ or Ehrschatz, was sometimes paid to the lord by the grantee. ${ }^{4}$ At most places however the Ehrschatz, when it existed, was due the community. At Zabern, ${ }^{5}$ Schwaney, ${ }^{6}$ Eisenach, ${ }^{7}$ and Lechnich ${ }^{8}$ it was fixed, though it varied slightly in the different towns. More commonly the fee was proportional to the value of the tenement and was expressed as a fraction of the selling price or the rent. This was the case at Wesel, ${ }^{9}$ Gehrden, ${ }^{10}$ Soest, Medebach, ${ }^{11}$ and Beckum. ${ }^{12}$

1 See von Maurer, Geschichte der Städteverfassung, i, p. 399.

${ }^{2}$ Cf. Normandy, where the usual alienation fee (treizième) was high, uniform, and invariably due a lord.

3 'Sellings,' sometimes ' cate' in England.

'Urkundenbuch der Stadt Strassburg, iii, introd., p. xlii. The lord was the receiver, but it seems that he had to bargain over his fee. See ibid., p. 33 for an illustration where the contract called for the payment of the Ehrschatz and also secured a right of first purchase to the grantor.

${ }^{5}$ Dagobert Fischer, Geschichte der Stadt Zabern (Zabern, 1874), p. I42. 4 d. to the town officials "zu gezugniss, und soll der Winkauff sein xvi d."

${ }^{6}$ Gengler, Stadtrechte, p. 420 , I2d.

${ }^{7}$ F. Philippi, Zur Verfassungsgeschichte der westfälischen Bischofsstädte (Osnabrück, I894), p. IоI, $a .1283$. The grantor gave I 2d. to the Vogt, the grantee $6 \mathrm{~d}$. to the Schöffen.

${ }^{8}$ Gengler, Stadtrechte, p. $242, a .1279$. The fee was 4 d.; it seems to have been due only when an inherited tenement was sold to a newcomer. Cf. Preston.

9 Ibid., p. 525. Due when 'domus et area' (house and lot) were sold: the fee was I 2 d. for each penny of rent.

${ }^{10}$ Ibid., p. 145. 2d. in each mark of purchase. It was called the 'Vorhüre' and seems to have been due only when an inherited tenement was sold.

${ }^{11}$ Ibid., p. 283: twice a year's rent, paid by grantee.

${ }^{12}$ F. Philippi, Zur Verfassungsgeschichte der westfälischen Bischofsstädte, pp. 22-23, ante 1245; paid by both grantor and grantee. Leave to sell must also be obtained from the Räthmanner. Cf. Dublin. 
These illustrations show a remarkable resemblence between alienation fees in the cities of Germany and those in the boroughs of England. In each country at a few towns of no importance fixed alienation fees were paid to a lord; in a greater number the fees, commonly fractional, were paid the town. A shilling for each penny of rent leaves one in uncertainty as to the amount of the fee, but twopence in each mark of purchase, one-eightieth of the price, reminds one strongly of the proportional fee in the Cinque Ports and some Flemish towns, while fourpence ' $z u$ Gezeugniss' and sixteen pence for 'Weinkauf' call to mind like customs in Hereford and Beverley. ${ }^{1}$

Free Sale. It is in connection with sale and devise that the term ' mobility' conveys its fullest meaning. Following the order of the text with reference to the presence or absence of the kin's preëmption we turn first to the cities where sale was free. Before considering these in detail it should be premised that the kin's retrait would lose more than half its meaning in those towns, of which, however, there were very few, where land was the only realty, the house being considered a chattel and not attached to the land.

At Stade sale was free to one class of holders, the lords of the 'areas.' At Kiel ${ }^{3}$ and Spires ${ }^{4}$ inheritance might be sold. Possibly sale was free at Bodenwerder ${ }^{5}$ there was no restriction thereon at Eisenach, ${ }^{6}$ and very probably none at Stralsund. ${ }^{7}$ Inheritance might possibly

I Registration fees are frequently noted, as at Cologne (1258), Landsberg, Magdeburg, Munich, and other towns; they were sometimes called L'rkundspfennige. At Cologne, for instance, the Vogt got i $2 d$. , the Schöffen i pf. each, the beadle 2 pr.

2 Gengler, Stadrechte, p. 457: the kin's preëmption was customary in respect to sale of an inheritance "nisi forte dominus areae eam vendiderit in propria persona."

3 (i. Humcyer, Die Stadibüeher des Mittelalters (Berlin, is 600 ), p. 41, a. 1264-89: 'hereclitas' might be solel. The same author says that this was the case at Wismar (ibid., 1. 35); he is very likely wrong.

4. Hilgarel, l'rkunden zur Geschichte der Stadt Speyer (Strasburg, I 885), p. 192: 'iure hereditario habenda.' Many sales are recorded as ' ex successione paterna.' See also von Maurer, Geschichte der Städtcierfassung, iii, p. $5^{\circ}$ S.

5 Gicngler, Studtrechte, p. 28, a. 1287 : " si civis vendere voluerit domum suam ct recelere, impediat nullus eum "; this may refer to an alienation fee.

${ }^{6}$ Ibicl., p. 101 , a. $2_{2} \mathrm{~S}_{3}$.

7 Frederik Jabricius. Das alteste Stralsundische Stadtbuch (Borlin, 1872), 1). 107, a. 1,300. ()ur doubt of absolute frecdom arises from the fat that infrequently consent to sale woturs in a grant of an heredity. This consent, however, apyears to have been given only when a minor's property, which was of course inherited, was solll; these who consented were probalily guardians. In one grant of 1287 
be sold freely at Brunswick, ${ }^{1}$ at Gehrden, ${ }^{2}$ and probably at Heilbronn. ${ }^{3}$ Sale was free at Rotenburg, ${ }^{4}$ and possibly at Lechnich, ${ }^{5}$ Frauenburg, ${ }^{6}$ and Worms. ${ }^{7}$ Inheritance might be freely sold at Colmar; ${ }^{8}$ at Hildesheim ${ }^{9}$ and Zuzenhausen ${ }^{10}$ its alienation was hampered merely by formalities.

certain burghers promised the grantee to secure her from damage if a 'propior heres' should claim within year and day (ibid., p. 67): in another grant is a record of a brother's consent. The many grants of heredities (ibid., pp. 4-165) contain no record of heir's consent, and heirs there must often have been.

${ }^{1}$ Ludwig Hänselmann, Urkundenbuch der Stadt Braunschweig (Brunswick, r862-r91 2), ii, p. 224, c. r300: "Swe so ein erve koft, de sal komen vor den voget," 'kaufen' probably for 'verkaufen,' why should an heir qua heir come before bailiff or steward when he bought? In I306 an inherited house was sold (ibid., ii, p. 297). But see Brunswick under Restricted Sale, p. 204.

${ }^{2}$ Gengler, Stadtrechte, p. I45, a. I319.

${ }^{3}$ Carl Jäger, Geschichte der Stadt Heilbronn (Heilbronn, 1828), p. 125, a. 1319. An estate was sold by the heirs; they may, however, have had no heirs of their own.

4 J. D. W. von Winterbach, Geschichte der Stadt Rothenburg an der Tauber (Rothenburg, 1826-27), i, pp. 62-63, a. 1336: "vom H. von I. ihres Vaters Theil des Burgsassen . . . kaufte." H. W. Bensen, Historische Untersuchungen über die ehemalige Reichstadt Rotenburg, p. 99: "So konnte man z. B. ein Haus als Eigenthum ganz nebst einem Theil des Erbes davon verkaufen."

${ }^{5}$ Gengler, Stadtrechte, p. 243, a. 1279. A newcomer must pay a fee on taking up an heredity, which most probably he had bought; newcomers were not likely to be heirs of tenements within the town. See Lechnich, under Restricted Sale, p. 205.

${ }^{6}$ Gengler, Stadtrechte, p. 57I, $a$. I318. The town is said to have had free sale ' as at Lübeck.' In each place the Stadtrecht has little to say in respect to sale though much as regards the law of inheritance. Rents, grants of which were commonly subject to the same limitation as grants of realty, were alienable at Lübeck in 1 240; at Goslar, in 1390, the freedom being then granted by the Emperor Wenceslaus. See G. Homeyer, Stadtbücher des Mittelalters, p. 55.

${ }^{7}$ Heinrich Boos, Urkundenbuch der Stadt Worms (Berlin, 1886-93), vol. ii. Records and grants of rents and tenements $a$. 1301-1400 (the period covered by this volume) have no trace of any restriction on sale.

${ }^{8}$ T. F. X. Hunkler, Geschichte der Stadt Colmar (Colmar, 1838), p. 4I. The age of majority for witnessing was 12 years, for selling inheritance 15 years. Cf. however, Gengler, Stadtrechte, p. 74, Colmar, $a$. 1278: " mit der selben kinte willen, ob si ziren tagen comen sint."

${ }^{9}$ Richard Döbner, Urkundenbuch der Stadt Hildesheim (Hildesheim, I881rgor), i, p. ro5: "Si aliquis . . habet pueros quos ab hereditate sua vult aut debet separare, hoc erit coram consulibus."

${ }^{10}$ J. P. Glock, "Burg, Stadt, und Dorf" Zuzenhausen (n. p., [1896], privately printed), p. 26. See also G. L. von Maurer, Geschichte der Städteverfassung, iii, p. 568. At Zuzenhausen the consent of the Elector Palatine was necessary; at Spires sale of inheritance must be made before the Chamberlain's court. Sale of purchase was before the ordinary town court. 
Restricted Sale. This topic, except as it concerns comparatively few and unimportant impediments to mobility, such as consent by the town council, is mainly a matter of the kin's preëmption. Where this feature of the ancient land law was recognized by a Stadtrechte there can be no question that the sale was restricted, unless later records in respect to grants should show that an early custom had been set aside by the necessities of commerce. Evidence for such change in the law must be ample and strong.

Purchase alone was freely alienable at Augsburg, ${ }^{1}$ Gelnhausen, ${ }^{2}$ and Quedlinburg. ${ }^{3}$ At Stade, ${ }^{4}$ Attendorn, ${ }^{5}$ Passau, ${ }^{6}$ Hanover, ${ }^{7}$ Pesth, ${ }^{8}$ Strasburg, ${ }^{9}$ and probably at Erfurt and Frankfort ${ }^{10}$ inheritance might not be sold without the heirs' consent. The urban land law was also the same at Brunswick, ${ }^{11}$ Hamburg, ${ }^{12}$ Ülzen, ${ }^{13}$ Din-

$1 \mathrm{~K}$. W. Nitzsch, Ministerialität und Bürgcrthum, p. 289, i th century:

2 Gengler, Stadircchte, p. I 46, I 2 th century.

${ }^{3}$ Stadtrecht von Quedlinburg, in G. Homeyer's Stadtbiicher des Mittelalters, p. 54, I 4 th century.

4 Gengler, Stadirchte, p. 457, a. 1209. Only a 'dominus areae' might sell freely. In this and other Stadtrechte the usual formula is that he "who has quiet possession of an heredity for a year and a day is the most favored person in respect to holding the same,' from which the presence of the kin's preëmption is to be inferred. The expression may also be used in connection with possession in general in towns from whose land law the kin's retrait had disappeared.

${ }^{5}$ Ibid., p. 13, a. I 222. 'Bona hereditaria' might not be sold except to a townsman. This may refer only to inherited chattels, in which case there is no question as regards preëmption.
Ibid., p. 344 , a. 1225.
7 Ibid., p. 186, a. $12+1$.
8 Ibid., p. 354, a. 1244.

9 Crkundenbuch der Stadt Strassburg, i, p. 45 I, a. 1265, and ii, p. 66, a. 1287 : heirs consented to sale.

${ }^{10}$ F. M. Lambert, Dic allere Geschichte und Verfassung der Stadt Erfurt (Halle, 1868), pp. 122-123, a. 1201: a tenement " in deren Besitz der Verkiufer persönlich nicht gesetzt ist " might be sold or alienated in any way in spite of heirs. This would not affect the lowest holder or his heirs in any way.

Restriction seems to have been the rule, to judge from communications between Frankfort and Erfurt and from a provision in the Stadtrecht forbidding sale in mortmain, but allowing a burgher to sell "que de iure vendere poterit" (ibid., PP. $13(3,-137)$.

11 R. Woebner, Städleprizilegien Herzog Otto des Kindes, p. 31, a. 1240-52. See Brunswick under Free Sale, where it should apparently stay. This evidence for restriction is much earlier than the evidence for freedom.

12 J. C. (iries, Dic Hamlurgischen Studt-Erbe-und Rente-Bïcher (Hamburg, i 830 ), p. 15 , a. $1270,1292,1497$. Inheritance was often sold at Hamburg though only when guarantors against damage by ejectment could be obtained. These could not prevent ouster of possession by an heir, but as it were underwrote the buyer against disturbance of possession within year and day.

${ }^{13}$ Gengler, Stadtrechtc, p. 49\%, a. 1270. 
golfing, ${ }^{1}$ Überlingen, ${ }^{2}$ and probably at Lechnich. ${ }^{3}$ The kin's preëmption probably existed at Wismar ${ }^{4}$ and at Bamberg, ${ }^{5}$ and certainly at Bremen, ${ }^{6}$ Verden, ${ }^{7}$ Neuburg, ${ }^{8}$ Naumburg, ${ }^{9}$ Cösfeld, ${ }^{10}$ Rottweil, ${ }^{11}$ Hüssen, ${ }^{12}$ apparently at Radolfzell, ${ }^{13}$ Duderstadt, ${ }^{14}$ Dattenried, ${ }^{15}$ and at Zabern. ${ }^{16}$ At Ratisbon ${ }^{17}$ and at Munich ${ }^{18}$ only purchase was alienable without consent.

1 Christian Haeutle, Einige altbayerische Stadtrechte (Munich, 1889-92), i, p. 54, a. I 274. No one might consent for a minor heir; sale waited on age of majority.

2 Martin Gerbert, Codex Epistolaris Rudolphi I (typis San-Blasianis, 1772), p. 229, a. 1275: "volumus ... quod nemo civium civitatis praedictae . . in hereditate succedat alicui . . . nisi heres proximior." This may refer to the law of succession only but implies also the presence of the kin's preëmption.

${ }^{3}$ Gengler, Stadirechte, p. 242 . The evidence for restriction at Lechnich preponderates.

4 Ibid., p. 551, a. 1323: no one might sell an heredity.

One or two instances of towns may be found, with qualifying statements appended, in each list. Restriction in such is commonly taken from an old Stadtrechte, freedom from a local Urkundenbuch.

5 Ibid., p. 17, a. I326.

${ }^{6}$ D. R. Ehmck and W. von Bippen, Bremisches Urkundenbuch (Bremen, 18731902), ii, p. 304, a. 1329.

7 Gengler, Stadtrechte, p. 509, a. 1330 . At Verden year and day were said to mean "dre Daghe ses Weken un en Jar."

${ }^{8}$ Haeutle, Einige altbayerische Stadtrechte, i, p. 90, a. 1332.

9 Gengler, Stadtrechte, p. 309, a. I337.

10 F. Darpe, Coesfelder Urkundenbuch, i, p. 43, a. 1341. Heirs consented to sale of a rent.

11 Heinrich Günter, Urkundenbuch der Stadt Rottweil, im Wïrttembergische Geschichtsquellen, iii (1896), pp. 85, 106, a. 1341. Even 'Eigengütlein' were sold with the son's consent.

12 Gengler, Stadtrechte, p. 208, a. 1348.

13 Urkunden der Stadt Radolfzell (Radolfzell, I878), p. 5, a. I401. The recorded grants, many of which are grants by widows to the convent, are not conclusive. There are many records of grants in which no consent was noted; all may be of purchase.

14 Gengler, Stadtrechte, p. 93. 15 Ibid., p. 78, a. $135^{8}$.

16 D. Fischer, Geschichte der Stadt Zabern, p. I42, a. 1489 . Two weeks' notice of sale must be given. Cf. Northampton.

At Beckum the Rathmänner's consent was needed for alienation (Philippi, Zur Verfassungsgeschichte der westfälischen Bischofsstädte, p. 24).

17 Gengler, Stadtrechte, p. 375.

18 Franz Auer, Das Stadtrecht von München (Munich, 1840), Einleitung, p. cxxxi: ewige Gilt and Eigenthum were subject to year and day. See also ibid., pp. $15^{-16}$.

Von Maurer, Geschichte der Städteverfassung, i, p. 423, notes the presence of the kin's preëmption in Lübeck, Bremen, Hamburg, and a few other towns. See also ibid., pp. 424-425. 
The number of towns in this list of restriction is about twice that in the list of freedom. However, many important cities in the valley of the Rhine do not appear in either list, while most of the records on which this conclusion in respect to sale in the German towns is based are of earlier date than corresponding records in the English boroughs, where the fourteenth and fifteenth centuries often saw the land law modified to greater freedom. Yet when all has been said, it is apparent that the land law of the English customals shows greater flexibility in the matter of sale than that of the German Stadtrechte, even the Stadtrechte of the commercial cities of the Hanse. Such at least was the case as far as concerns the letter of the law.

Looking further into this question of restriction, at a glance one sees in the cities of Germany the same method of bending a theoretically rigid land law as in the English boroughs. The German burgher sold ' in necessity ' in exactly the same way, and no doubt swore with quite as much truth in his oath before the town magistrates, as if he had lived in Northampton and not in Naumburg. Indeed he seems to have a prior claim to the invention of this simple legal fiction, sale in need being a matter of record in Germany early in the twelfth century. From that time its use in towns where the kin's preëmption remained in force was so wide-spread that at the close of our period it was a general feature of the urban land law. ${ }^{1}$

Free Devise. In the matter of devise the disproportion between the respective numbers of towns of freedom and restriction was even greater than in the matter of sale: mobility was less complete in the German cities than in the English boroughs. At Kiel devise seems to have been free; ${ }^{2}$ at Stralsund the balance of the evidence inclinis

I Some of the towns which embodied this provision in their Stadlrechte were Freiburg-im-Breisgau (Gengler, Stadtrechle, p. 127, a. 1 1 20); (ichnausen (ibid., p. I46, a. 1169); Quedlinburg (G. Homeyer, Studtbächer des Willelallers, p. 54, Stadirecht ion (Juedlinburg. I $3_{\text {th }}$ century); Passau (A. Erhard, Geschichie der Studl Passuu, Pp. I12-I13, a. I209) - one might sell "wegen häuslicher Not" and get judicial protection if the heir objected; Würzburg (S. Rietschel, in Zcitschrift der Suvigny-Stiftung fir Rechtsgeschichte, xxii (1901), 1. 222); Schwaney ((iengler, Stadirechte, p. 420); Naumburg (ibid., p. 309, (1. 1337) - a father might sell in need and keep two-thirds of the price received, "und den kinden den dritten pfennig dar abe ghebe "; Verten (ibid., p. 509. a. 1330) - "need' must be declared before the Rat.

2 Ilomeyer, Stadlbucher, p. $4 \mathrm{r}, c . a, \mathrm{1} 250$. The evidence is from a record of devise. 
toward liberty. ${ }^{1}$ Devise was possibly free at Weida, ${ }^{2}$ at Jerichow, ${ }^{3}$ and at Troppau. ${ }^{4}$ In many of the Stadtrechte the prohibition to devise inheritance seems to apply only to cases where heirs of the body were living; more distant relations might be excluded by a will. ${ }^{5}$

Restricted Devise. At Grech ${ }^{6}$ neither sort of realty might be devised. Purchased tenements alone were devisable at Pesth, ${ }^{7}$ Diessenhofen, ${ }^{8}$ Überlingen, ${ }^{9}$ Friedrichshafen, ${ }^{10}$ and probably at Spires ${ }^{11}$ and

1 Fabricius, Das älteste Stralsundische Stadtbuch, pp. 50-56, a. 1279-88. Inheritance was devised in several cases. The records may refer to chattels but probably most of them refer to tenements. One devisor ( $i b i d .$, p. 56 ) gave his eldest son 80 marks; to his wife and another son "dedit hereditatem suam integram." The reference is probably to chattels. In I288-1300 a brother consented to devise of an heredity (ibid., p. 93); the executors were sureties in case an heir should claim within year and day. It seems probable that we have here a case of a child whose whereabouts and even existence were unknown, and to whom the father wished his land to go if alive. Otherwise the brother would have been heir; the tenement was not willed to him. See also ibid., p. I 24: $a$. 1303 for devise of inheritance. Fractions of heredities were also devised, ibid., pp. I17, I21. On the other hand, see Gengler, Stadtrechte, p. 471, a. 1353 (Stralsund).

2 Gengler, Stadtrechte, p. 515, a. I377. The burghers had permission to devise 'Guter'; possibly hereditary chattels were meant.

${ }^{3}$ Ibid., p. 209, a. I336, - ' children might be disinherited '; the reference may be to chattels alone.

4 Ibid., p. 49I, a. I464. Permission was given to devise realty.

5 See ibid., p. $210, c$. a. I 250 , Iglau. The law of that town was that if a burgher died leaving neither wife, nor child, nor will, the next heir should succeed. There seems no need for such a rule if devise were restricted, unless the clause applied to purchase alone.

$\mathrm{Ulm}$ may have been a town of free devise; its records contain many wills in kinsmen's favor. The tenements devised, however, may all have been ' purchase.' See Friedrich Pressel, Ulmisches Urkundenbuch (i, Stuttgart, I873), p. 29 I et pass.

${ }^{6}$ Gengler, Stadtrechte, p. I 70, $a$. I 242. I have found no other town where purchase was undevisable.

${ }^{7}$ Ibid., p. $334, a$. 1244 .

8 Ibid., p. 80, a. I 260 : ' the heirs shall have heredity.'

9 Ibid., p. 495 , a. I 275 .

${ }^{10}$ Ibid., pp. I4I-I42, $a$. I 275 .

11 A. Hilgard, Urkunden der Stadt Speyer, pp. 179, 240-241, a. 1304, 1317. In the one case husband and wife devised their whole estate each to the other, subject "juxta jus et consuetudinem civitatis Spirensis" to a forfeit of 400 marks in case a nearer heir appeared. The second case was similar, the forfeit provided being roo marks of silver. Cf. London, where a husband might not devise realty to his wife for a term beyond her life.

Yet in 1334, a Bürgerin ('iungvrowe') of Spires, Katherine Swenin, devised a house (ibid., p. 380 ). It could hardly have been other than inheritance; a $J_{u n g-}$ frau is not usually in the market, at least the market for real estate. 
Lucerne. ${ }^{1}$ At Landshut a tenement might be devised only in the absence of a direct heir. ${ }^{2}$ At $\mathrm{Ulm}^{3}$ and Bruk ${ }^{4}$ devise was limited to tenements of purchase.

It is in connection with sale and devise that the land laws of the German cities and the English boroughs differ most. The basis of this difference seems to lie on a distinction between the legal nature of area or land and that of domus or house. In England each was a burgage tenement, and though each might be, and in the later middle ages often was, separately alienated and separately held, the legal character and the degree of alienability were the same for each. In Germany, though the house was seldom considered a chattel, ${ }^{5}$ something of the chattel nature seems to have pertained to it; it was held in less reverence than the land; it was more of an object of commerce, and was often more freely alienable than the area on which it stood. Fluid as realty in the German cities might be, England was eminently the land of free sale, and preëminently the land of free devise.

1 Gengler, Stadtrechte, p. $274, a$. 1252 . In this as in many other Stadtrechle the statement that the 'nearest heir shall have heredity' may refer to intestacy only.

${ }^{2}$ Ibid, p. 236, a. 1241. This refers probably to inheritance; it allows devise to those " die nicht kind hieten und auch erben liessen."

${ }^{3}$ Gustav Veesenmeyer and Hugo Bazing, Ulmisches Urkundenbuch (ii, I, Ulm, I898), p. 224, $a$. I34I. A tenement was devised to a convent "es wäre denn, dass sie Leibeserben hinterlassen," though this may be only a conditional clause in favor of a future or an absent heir.

${ }^{4}$ Gengler, Stadtrechle, p. 58, a. 1296. A deceased burgher's house went to his heir "als von alter ist herkhomen": this may refer to intestacy only. Probably Cleves should be added to this list: see ibid., p. 64 .

5 'The houses in created towns may sometimes so have been considered. 


\section{BIBLIOGRAPHY}





\section{BIBLIOGRAPHY}

THIS list contains the more important authorities mentioned in the footnotes, with, in some instances, a fuller statement of title. It does not purport to be a complete record of all the works consulted. Unless it is otherwise stated, London is to be understood as the place of publication for the English books here cited. Since the writers who have treated directly of the burgage tenure are few, I have, contrary to the usual bibliographical practice, and purely as a matter of convenience, grouped their writings at the beginning. These secondary works are followed by the sources, which I have arranged in a single alphabetical list. A brief account both of the sources and of the secondary works may be found above, pp. 5-10.

\section{SECONDARY WORKS}

(a) For the Tenure in England

Bateson, Mary. Borough Customs. Edited for the Selden Society. I904o6. 2 vols.

- The Laws of Bretenil. In the English Historical Review, xv, pp. 7378, 302-318, 496-523, 754-757; xvi, pp. 92-I10, 332-345.

Maitland, F. W. Township and Borough. With an Appendix of Notes relating to the History of the Town of Cambridge. Cambridge, $\mathrm{I} 898$.

Merewether, H. A., and Stephens, A. J. The History of the Boroughs and Municipal Corporations of the United Kingdom. I835. 3 vols.

Pollock, Sir Frederick, and Maitland, F. W. The History of English Law before the Time of Edward I. 2d ed. Cambridge and Boston, I898. 2 vols.

(b) For the Tenure in the Netherlands, Germany, and Parts of France

Arnold, Wilhelm. Zur Geschichte des Eigentums in den deutschen Städten. Mit Urkunden. Basel, I86I.

Curie Seimbres, Alcide. Essai sur les Villes fondées dans le Sud-Ouest de la France aux XIII et XIV Siècles sous le Nom Générique de Bastides. Toulouse, I880.

Des Marez, Guillaume. Étude sur la Propriêté Foncière dans les Villes du Moyen-Âge, et spécialement en Flandre. Ghent, etc., r 898.

Génestal, R. La Tenure en Bourgage: Étude sur la Propriêté Foncière dans les Villes Normands. Paris, I900. 
Keutgen, Friedrich. Untersuchungen iiber den Ursprung der deutschen Stadtverfassung. Leipsic, I 895. (Cited as Deutsche Stadtverfassung.)

- Urkunden zur städtischen Verfassungsgeschichte. Berlin, I90 I.

Legras, Henri. Le Bourgage de Caen: Tenure a Cens et Tenure d Rente $\left(X I^{e}-X V^{e}\right.$ Siècles). Paris, I9r r.

\section{SOURCES}

(Including local histories and similar works from which documents are cited.)

(Abbreviations: R. C., Record Commission. R. S., 'Rolls Series' Rerum Britannicarum Medii Aevi Scriptores, or Chronicles and Memorials of Great Britain and Ireland during the Middle Ages.)

Allen, John. History of the Borough of Liskeard. London, etc., 1836 .

Arnold, Thomas, editor. Memorials of St.Edmund's Abbey. I89o-96. 3 vols. (R. S.)

Atcheson, R. S. Report of the Case of the Borough of Petersfield. $\mathbf{I} 83 \mathrm{I}$. Atkinson, J. C. Memorials of Old Whitby. 1894.

Bacon, Nathaniel. The Annalls of I pswiche. Edited by W. H. Richardson. Ipswich, I 884.

Baines, Thomas. History of the Commerce and Town of Liverpool. 1852 .

Baker, J. B. The History of Scarborough. I 1882.

Ballard, Adolphus. Chronicles of the Royal Borough of Woodstock. Oxford, I 806 .

- - The Domesday Boroughs. Oxford, I904.

- , editor. British Borough Charters. 1042-1216. Cambridge, I913.

Bateson, Mary, editor. Records of the Borough of Leicester, IIO3-I5OO. I $899-1905.3$ vols.

[Bedford.] A Schedule of the Records and other Documents of the Corporation of Bedford. Bedford, $\mathrm{I} 88_{3}$.

Benham, W. G., editor. The Red Puper Book of Colchester. Colchester, I 902 .

- editor. The Oath Book or Red Parchment Book of Colchester. Colchester, 1007 .

Bennett, James. The History of Tewkesbury. Tewkesbury, I8zo.

Bickley, F. B., editor. The Little Red Book of Bristol. Bristol, 1900. 2 vols.

- A Calcudar of Deeds, chiefly Reluting to Bristol, Collected by $G$. $\mathrm{W}$. Braikenridge. Edinburgh, I $S 99$.

Blomefield, Francis, and Parkin, Charles. An Essay towiards a Topographical II istory of the County of Norfolk. ISO5-IO. I I vols.

Boyle, J. R. The Early History of the Town and Port of IIedon. Hull and York, I 1895 .

Boys, William. Collections for an History of Sandwich in Kent. Canterbury, 1792 .

Bracton, Henry de. De Legibus et Consuetudinibus Angliae libri quinque. Edited by Sir Travers Twiss. ${ }_{1} 878-83 . \quad 5$ vols. (R. S.) 
Brand, John. The History and Antiquities of Newcastle upon Tyne. $\quad$ I 789. 2 vols.

Britton. See Nichols, F. M.

Brown, William, editor. Yorkshire Inquisitions. York, I892-I906. 4 vols. (Yorkshire Archaeological Society. Record Series.)

Burton, J. R. A History of Kidderminster. $\mathrm{I} 890$.

Calendarium Rotulorum Chartarum et Inquisitionum ad quod Damnum. I803. (R. C.)

Calthrop, Sir Henry, editor. The Liberties, Usages, and Customes of the City of London. $\mathrm{I} 642$.

Cathrall, William. The History of Oswestry. Oswestry, I855.

Caulfield, Richard, editor. The Council Book of the Corporation of the City of Cork. Guildford, $\mathbf{1} 876$.

- editor. The Council Book of the Corporation of Kinsale. Guildford, I879.

, editor. The Council Book of the Corporation of Youghal. Guildford, I 878 .

Chanter, J. R., editor. The Barnstaple Records. Barnstaple, I879-8ז. 2 vols. Chapman, H.S. Deal, Past and Present. 1890.

Chartae, Privilegia, et Immunitates, II7I-I395. Printed by the Irish Record Commission, I829-30. Dublin, etc., I889. (Sometimes referred to as Chartae Hiberniae.)

Clark, G. T., editor. Cartae et alia Munimenta quae ad Dominium de Glamorgan pertinent. Dowlais, I885-93. 4 vols.

Coke, Sir Edward. The First Part of the Institutes of the Laws of England; or, A Commentary upon Littleton. Philadelphia, 1853. 2 vols.

Cole, Robert, compiler. Rental of all the Houses in Gloucester, A. D. 1455. Edited by W. H. Stevenson. Gloucester, 1890.

Cooper, C. H. Annals of Cambridge. Cambridge, 1842-1908. 5 vols.

Cooper, W. D. The History of Winchelsea. 1850.

Cromwell, Thomas. History and Description of the Town and Borough of Colchester. 1825 .

Daniel-Tyssen, J. R., compiler. Royal Charters and Historical Documents relating to the Town \& County of Carmarthen. Carmarthen, 1878 .

Domesday-Book, seu Liber Censualis Willelmi Primi Regis Angliae. (Including Liber Winton', etc.) I783-I8I6. 4 vols. (R. C.)

Dominicus, Prior of Evesham. Chronicon Abbatiae de Evesham ad Annum I418. Edited by W. D. Macray. I863. (R. S.)

Dugdale, Sir William. Monasticon Anglicanum. Edited by John Caley, Henry Ellis, and Bulkeley Bandinel. I8I 7-30. 6 vols.

East, Robert, editor. Extracts from Records in the Possession of the Municipal Corporation of the Borough of Portsmouth. Portsmouth, I89I.

Elton, C. I. The Tenures of Kent. 1867.

Ferguson, R. S. The Royal Charters of the City of Carlisle. Carlisle, etc., I 894 .

Fishwick, Henry. The History of the Parish of Preston. 1900.

Frost, Charles. Notices relative to the Early History of the Town and Port of Hull. I 827 . 
Gale, Peter. An Inquiry into the Ancient Corporate System of Ireland. 1834 .

Gilbert, J. T., editor. Calendar of Ancient Records of Dublin. Dublin, I 889-I9 I I. I 5 vols. (Vols. 8-I 5 edited by Rosa M. Gilbert.)

-. II istory of Dublin. Dublin, I $854-59.3$ vols.

- editor. Historical and Municipal Documents of Ireland, A. D. II72I320. I 870. (R.S.)

Glanvill, Ranulf de. A Treatise on the Laws and Customs of the Kingdom of England. Translated by John Beames. I8I2.

Glover, J. H. Kingsthorpiana. I883.

Great Britain. - Public Record Office. Calendar of the Charter Rolls preserved in this Office, I226-I344. I90I-I 2. 4 vols.

- Calendar of Inquisitions post Mortem and other Analogous Documents. Vols. i and ii (Henry 11 I and Edward I), I904-o6; vols. v-vii (Edward II, I-9 Edward III), I908-o9; Henry VII, vol. i, I898.

- Patent Rolls, I2I6-32; Calendar of Patent Rolls, 1232-1485. I90I-. 46 vols. published; a few gaps unfilled at date of writing. The most valuable source for the tenure.

- A Descriptive Catalogue of Ancient Deeds in the Public Record Office. I $890-1905.5$ vols.

Gribble, J. B. Memorials of Barnstaple. Barnstaple, i 830.

Guilding. J. MI., editor. Reading Records. I892-96. 4 vols.

Hall, Hubert, editor. The Pipe Roll of the Bishopric of Winchester, 1208-og. I903.

Hardwick, Charles. IIistory of the Borough of Preston. Preston, 1857.

Hardy, Sir T. D., editor. Rotuli Chartarum in Turri Londinensi asservati. I. I. II99-1216. (No more published.) i837. (R. C.)

Hardy, W. J., editor. A Calcndar to the Records of the Borough of Doncaster. Doncaster, I 899-1903. 4 vols.

Harwood, Thomas. The II istory and Antiquities of the Church and City of Lichficld. Gloucester, I806.

Head, Robert. Congleton, Past and Present. Congleton, i $\$ 87$.

Hedges, J. K. The II istory of IV allingford. I8SI. 2 vols.

Heginbotham, Henry. Stockport, Ancient and Modern. IS82-02. 2 vols.

Hemingway, Joseph. II istory of the City of (hester. Chester, I 83 I. 2 vols.

Hills, W. H. The II istory of East Grinstead. East Grinstead, etc., 1006.

Hoare. R. C. The II istory of Hodern Wiltshire. I $822-43.6$ vols.

Hodgson, John. A llistory of Morpeth. Newcastle, I 832 .

Holloway. William. The II istory and Antiquitics of the Ancicut Toun and Port of Rye. Is+7.

Hore, l'. H. Mistory of the Tow'n and County of lliexford. I000-I I. 6 vols. Horwood, A. J., and Pike, L. O., editors. Fear Books of Edi'ard I and

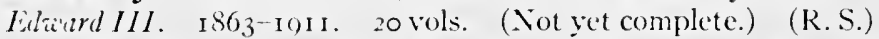

Hudson, William, and Tingey. J. (.., editors. The Records of the City of Norich. Norwich and Iondon, I0o6-10. 2 vols.

Hutchinson. William. The II istory and Antiquitics of the County Palatine of Durhum. Newcastle, etc., I $785-94.3$ vols. 
Illingworth, William, editor. Rotuli Hundredorum Temp. Hen. III \& Edw.I. ('Hündred Rolls.') I8I 2-I8. 2 vols. (R. C.)

[Ipswich.] Le Domesday de Gippewyz. The Domus Day of Gippeswiche.

(In The Black Book of the Admiralty, ii.) 1873 . (R.S.)

James, John. The History and Topography of Bradford. I84I.

Johnson, Richard. The Ancient Customs of the City of Hereford. 1882.

Jones, W. H. R., and Macray, W. D., editors. Charters and Documents Illustrating the History of the Cathedral, City, and Diocese of Salisbury. I89I. (R.S.)

King, A. J., and Watts, B. H. The Municipal Records of Bath, II89 to I604. [1885.]

Leach, A. F. Beverley Town Documents. Edited for the Selden Society. I 900 .

Lenihan, Maurice. Limerick: its History and Antiquities. Dublin, 1866.

Lewis, E. A. The Medieval Boroughs of Snowdonia. I9I 2.

[Ludlow.] Copies of the Charters and Grants to the Town of Ludlow. Ludlow, [I821 ?].

Lyon, John. The History of the Town and Port of Dover, with a Short Account of the Cinque Ports. Dover, $18 \mathbf{I}_{3}-\mathbf{I} 4.2$ vols.

Madox, Thomas. Firma Burgi; or, An Historical Essay concerning the Cities, Towns, and Boroughs of England. I 726.

Maitland, F. W., editor. Bracton's Note Book. I887. 3 vols.

- - editor. Year Books of Edward II. 1903-10. 5 vols. (Selden Society.)

[Manchester.] The Court Leet Records of the Manor of Manchester, from I552 to I686, and from I73I to I846. Manchester, I884-90. I 2 vols.

Markham, C. A., and Cox, J. C., editors. The Records of the Borough of Northampton. 1898.2 vols.

Markham, C. A., editor. The Liber Custumarum: the Book of the Ancient Usages \& Customes of the Town of Northampton. Northampton, I895.

Matthews, J. H., editor. Cardiff Records. Cardiff, I898-I905. 5 vols.

Mayo, C. H. The Municipal Records of the Borough of Shaftesbury. Sherborne, r889.

Money, Walter. The History of the Ancient Town and Borough of Newbury. Oxford, etc., I887.

Morant, Philip. The History and Antiquities of the Toun and Borough of Colchester. $2 \mathrm{~d}$ ed. Chelmsford, I8I5. (Bound with Morant's History of Essex, vol. i, but with separate title and pagination.)

Mosley, Sir Oswald. History of the Castle, Priory, and Town of Tutbury. 1832 .

Moule, H. J. Descriptive Catalogue of the Charters, Minute Books, and other Documents of the Borough of Weymouth and Melcombe Regis, I252-I80o. Weymouth, I883.

Nichols, F. M., editor. Britton. Oxford, 1865. 2 vols.

Nichols, J. F., and Taylor, John. Bristol, Past and Present. Bristol, etc., I88I-82. 3 vols.

Owen, Hugh, and Blakeway, J. B. A History of Shrewsbury. 1825. 2 vols. 
Parker, John. The Early History and Antiquities of Wycombe. Wycombe, I 878 .

Parkin, Charles. The Topograpliy of Freebridge Hundred and Half, containing the History and Antiquities of the Borough of King's Lynn. Lynn, 1762 .

Parliamentary Papers. Session of 19 Feb.-1o Sept. I835. Vols. xxiii-xxviii. xxiii-xxvi. First Report of Commissioners Appointed to Inquire into Municipal Corporations of England and Wales. With an Appendix in five parts.

xxvii, xxviii. First Report of the Commissioners Appointed to Inquire into the Municipal Corporations in Ircland. With Appendices.

Peter, Richard, and O. B. The Histories of Launceston and Dunheved. Plymouth, 1885 .

Picton, Sir J. A. Memorials of Liverpool. 1875.2 vols.

- , editor. City of Liverpool. Selections from the Municipal Archives and Records, from the ${ }^{3}$ th to the I7th Century Inclusive. Liverpool, 1883. (Cited as "Picton, Liverpool Records, i.")

- editor. City of Liverpool. Municipal Archives and Records, I7oo to I835. Liverpool, I886. (Cited as "Picton, Liverpool Records, ii.")

Poulson, George. Beverlac; or, The Antiquities and History of the Town of Beverley. i 829 .

Riley, H. T., editor. Munimenta Gildhallac Londoniensis: Liber Albus, Liber Custumarum, et Liber Horn. I859-62. 3 vols. (R. S.)

Roberts, Charles, editor. Calendarium Genealogicum. Henry III and Edward I. 1865.2 vols.

[Rochester.] An Authentic Copy of the Charter and Bye-Laws of the City of Rochester. [London?], isog.

Rogers, J. E. T., editor. Oxford City Documents, I268-1665. Oxford, I 89 I.

Roots, George, editor. The Charters of the Town of Kingston upon Thames. 1797 .

Ross, John. Civitas Lincolniu. Lincoln, 1870.

Royal Commission on Historical Manuscripts. Reports. I870-. (Still in progress. Reports since the ${ }_{5} 5_{\text {th }}$ are mostly of private collections.)

Rymer, Thomas, compiler. Foedera, Conventiones, Literae, et cujuscunque Gencris Acte Publica. 2d ed., I726-35. 20 vols. New ed., 1816-60. 4 vols. (R. C.) Citations are from the edition prepared by the Record Commission.

Scott, John. Berwick-upon-Twecd: the II istory of the Town and Guill. 1888.

Seyer, Samuel. Memoirs It istorical and Topographical of Bristol and its Neighborhood. Bristol, $1 \$_{21-23 .} 2$ vols.

—, editor. Charters and Letters P'atent Granted by the Kings and Quecns of England to the Torin and City of Bristol. Bristol, $\mathbf{1} 8 \mathbf{2} 2$.

Sharpe, R. R., editor. Calcndar of Wills Proved and Enrolled in the Court of II usting, London, I258-I688. $\quad$ I889-90. 2 pts. 
Sharpe, R. R., editor. Calendar of Letters from the Mayor and Corporation of the City of London, circa A. D. 1350-r370. 1885 .

Shaw, George. Old Grimsby. Grimsby, etc., 1897.

Sheahan, J. J. History of the Town and Port of Kingston-upon-Hull. Beverley, [r866].

Simpson, Robert, compiler. A Collection of Fragments Illustrative of the History and Antiquities of Derby. Derby, 1826.2 vols.

Stanley, T. J., and others, and Mayor, etc., of Norwich, contestants. Evidence relating to Town Close Estate. [Norwich, I886.] (Record of a suit in the High Court of Justice, Chancery Division.)

Statham, S. P. H., editor. Dover Charters, and other Documents in the Possession of the Corporation of Dover. 1902.

Statutes of the Realm, The. I8ro-24. 9 vols. (R. C.)

Stevenson, W. H., editor. Records of the Borough of Nottingham. I882I900. 5 vols.

- Calendar of the Records of the Corporation of Gloucester. Gloucester, I 893 .

Stubbs, William. Select Charters. 8th ed. Oxford, I900.

Swinden, Henry. The History and Antiquities of the Ancient Burgh of Great Yarmouth. Norwich, I772.

Tait, James. Mediaeval Manchester, and the Beginnings of Lancashire. Manchester, I904.

Tate, George. The History of the Borough, Castle, and Barony of Alnwick. Alnwick, 1866-69. 2 vols.

Thompson, James. The History of Leicester. Leicester, etc., I849.

Thompson, Thomas. Ocellum Promontorium; or, Short Observations on the Ancient State of Holderness. Hull, 1824 .

Tomlinson, John. Doncaster. Doncaster, I887.

Wadley, T. P. Notes or Abstracts of the Wills Contained in the Volume Entitled the Great Orphan Book and Book of Wills, in the Council House at Bristol. Bristol, 1886.

Warburton, John, Whitelaw, James, and Walsh, Robert. History of the City of Dublin. $\quad$ I 8 I8. 2 vols.

Wardell, James. The Municipal History of the Borough of Leeds. 1846.

Watkins, John. An Essay towards a History of Bideford. Exeter, I792.

[Westminster.] Placitorum in Domo Capitulari Westmonasteriensi asservatorum Abbreviatio. I8I I. (R. C.)

Whitaker, John. The History of Manchester. I77I-75. 2 vols.

Widdrington, Sir Thomas. Analecta Eboracensia. 1897.

Williams, John. Ancient and Modern Denbigh. Denbigh, 1856.

Willmore, F. W. A History of Walsall. Walsall, etc., I887.

Yeatman, J. P., editor. Records of the Borough of Chesterfield. Chesterfield, etc., I 884 . 

I N DEX 



\section{N DEX}

Accumulation of burgages, 148-152; in Bamberg, 205.

Germany, I 79.

Acton Burnell, Statute of Merchants of, III, n. 2.

Adam the Fleming, 26, n. 3 .

Agardsley, 6r, 67, 73, n. 7, 96, n. 3, r64, n. I.

Aids, the, I I f.; in Normandy, I72; in Germany, I93; ransom, II; knighting, is f., 59; marrying, in f., 59 .

Albemarle, honor of, 148, n. 4 .

Albini, Hugh of, Earl of Sussex, II f., II 3 , n. 3 .

Alderley, Richard, I22, n. I.

Alfred the Great, king of England (87 I-

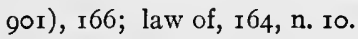

Alienation fees, $54 \mathrm{ff} ., 60,170,183$; in Normandy, I 72 f., I74, 182 ; in the bastides, 175 ; in the Netherlands, 176 ; in Germany, I79, I80, I82 $201 \mathrm{f}$.

Alnwick, 67, I22, I84.

Alsace, I98.

Altenburg, I96, n. 4.

Altringham, I72, n. I; landgable at, 67, 96, n. 3 ; free sale at 113 , I 84 ; free devise at, 133 , 152, n. 5 , I84; mortgage at, 147 .

Anne of Bohemia, wife of Richard II of England, 28, n. I.

Anstyn, John, I22, n. I.

Arnold, Wilhelm, 7, 8, I78, n. I, 2 I I.

Arras, 176 .

Arthez, 175, n. 2.

Arundel, Earl of, 20, n. I.

Astrad Canon, 98.

Attendorn, 204.

Augsburg, I79, 204.

Austria, I8I, n. 9.

Bacon, Sir Nicholas, , 2, n. 2.

Bakewell, 56, n. 6, 89, т32, 184.

\section{Baret, John, I22, n. 1.}

Barnstaple, I9; landgable at, 67 ; resists collection of the landgable, 73; devise unknown at, 136, 184 .

Barons' War, the (1263-65), 43.

Barre, Joan, wealthy widow, I49, n. 4.

Basel, 7, 85, I 78, n. I, I98, n. I.

Basingstoke, 82, I56.

Bastides, the, 7,98 , n. I, 99, n. 2, II3, n. 5, I 75, I8I, n. 2 .

Bateson, Mary, 6, 120, n. т, r36, n. 2, I66-I72, 2II, 2 I 2.

Bath, I74, n. 4; escheat at, 32, n. 2; landgable at, 65,67 ; sale price of a shop at, $80,8 \mathrm{r}$; rate of interest at, 85 ; restricted sale at, I2I, I 84 ; devise at, I34, I84.

Bath and Wells, bishop of, I13, n. 4, I26, n. I, I32, n. 7 .

Bayeux, I73, I74.

Beckum, 201, 205, n. I6.

Bedford, 64, 67, 105, n. 3 .

Bedfordshire, 43, n. I, 93, n. 4 .

Benjamin the Jew, 38 , n. 4 .

Berkelay, John de, 36, n. 6.

Berne, I79, I8r.

Berwick, 93, n. 4; wardship at, $\mathrm{r}_{5}, \mathrm{I} 8$; escheat at, 24, 9I, n. 2; landgable at, 67,71 ; rent simple at, 82 ; the waste at, I०5, n. 6; free devise at, 133, 184.

Best, John, 9o, n. 4 .

Best, Thomas, I 22, n. I.

Beverley, I 20, I28, n. 2, I83, I84, 202.

Bideford, 2I, 58, 67 .

Bielefeld, I96, n. 7 .

Bigod, Roger, Earl of Norfolk, 25, 3I, n. I, 39 .

Birde, John, I22, n. I.

Birmingham, 23, 46.

Bocher, John, I 2 , n. I. 
Bodenwerder, 202.

Bodmin, 64 , n. 8.

Bolebec, Hugh de, I60, n. 4 .

Bonseriant, W., 43, n. I.

Bootham, 19, n. 5 64, 131, n. 5 .

Borough-English, I31, n. I, 167, n. 2.

Botesford, 16, n. 6.

Bracton, Henry de, 5 f., I30, I43 f., 212.

Bradford, 67.

Bradninch, 67 .

Brain, Robert, 38 , n. 4.

Brakel, 195, n. 8, 197.

Bramwyth, 2I, n. 2.

Bregenz, 198, n. I.

Breisach, 197 .

Bremen, I79, 180, 205.

Breteuil, I $66 \mathrm{f}$.

Breteuil, Laws of, 6, I 2, n. 4, 19, n. 6, 55, ก. $6,57,97$, I19, n. 7, I 23, I 36 ff., 166I 72 .

Bridgnorth, 67, 71, 133, I52, n. 5, I 84 .

Bridgwater, 93, n. 4, 104, n. I, 145, n. I; landgable at, $67,7 \mathrm{r}$; rents simple at, 82 ; retained rent at, 86, n. 2 ; solar at, ı० , n. I; divisibility of realty at, 108, n. 2 .

Bridport, 50, n. 5 ; escheat at, 32, n. 2; landgable at, 68; sale price at, $8 \mathrm{I}$; rents simple at, 82 ; curtilage at, ror, n. I; free sale at, II 2,184 ; at feefarm, 154, n. I.

Bristol, 14, 15, n. 3 , 16, 19, n. 6, 27, 36, 37, 4 I, n. 2,50, n. 5 , I०2, ก. 2 , I 23,125 , n. I, 167,170, n. 8 ; attempts to keep the king's escheats, 28 , n. 1 ; its own lord, 59; burgage rents at, $65,68,76$; rent simple at, 83 ; receives a grant of the waste, Iо5; free sale at, I 12,113 , I 84 ; devise at, I33 f., 1 36, 1 38 , n. I, I 42 , n. $2,143,184$; accumulation of burgages in, 149,150 .

Iristollian boroughs in Ireland, I 69 .

Bruk, 208.

Brun, Fromund le, 3 i, n. I.

Brun, Sir Nigel le, 3 r, n. $\mathbf{~}$.

Brunswick, 203, 204.

Buckingham, i6o, n. 4.

Buckingham, Duke of, 73 , n. 5 .
Burgage, nature of the, 92-101.

Burgage rents, $61-106,159-162,165 f$., I $70 \mathrm{f}$; in Normandy, $173 \mathrm{f}$; in the bastides, 175; in the Netherlands, 176 ; in Germany, 180 , $199 \mathrm{ff}$.

Burgh, Hubert de, 35 , n. 2, 38, 88, n. 5 .

Burton-on-'Trent, 68.

Bury Saint Edmunds, 14, n. 2, 17, 19, 55 f., $64,68,72$, n. 4,76, n. 3 , II 7 , I 25 , n. 2 , I 26 , n. I, 140,184 .

Buxton, Robert, i 2, n. 2.

Bykes, 93, n. 4 .

Caen, $6 \mathrm{f}, \mathrm{I} 73$.

Caermarthen, 68,83 .

Cambridge, $6,25,38,45,93$, n. 4,163 , 184, 186; escheats at, 28, n. I, 30, 32, n. 2 ; grant of forfeitures to, 42 ; landgable and hawgable at, $62,63,64,68$, 74 , n. $1,76,78$, n. 1, 99 , n. 1, 161, 165, I66, n. 2, I68; rent simple at, 83 ; retained rent at, 86, n. 2 ; pepper rent at, 87 ; the waste at, 106, n. 1 ; union of messuages at, I09; borough court at, 129, n. 4; free devise at, 133, I 84 ; accumulation of burgages at, 150 ; commerce of, I53, n. I; grant of Firma Burgi, 155 .

Cambridge, University of, 32 , n. 2.

Canterbury, 4I, n. I, 93, n. 4; wardship at, 17 ; age of majority at, 18, n. 3 ; escheats at, 27, 29, 36; forfeiture at, 35,36 ; sale price at, $8_{\mathrm{I}}$; historians of, 133; free devise at, 133, I $8_{4}$; at feefarm (1234), 156; landgable at, I 59; aristocratic holdings at, 164.

Canute, king of England (1017-1035), $22,23,59,164$.

Canyngs, or Cannings, W., merchant of Bristol, I 49, 150.

Carbunel, Thomas, abbot of Gloucester, 54 , n. 1 .

Carliff, I 2, 55, n. 4, 9.3, n. 4, 131, n. 2; relief unknown at, r9; landgable at, 68, г 70 , n. 9; right to lease at, 89,90 , n. 4 ; holders of half-burgages have burgess rights, 108, n. 5 , 100; sale at, II4, 115 , I16, n. I, I 84 ; devise un- 
known at, 137, 184; mortgage at, 146; ecclesiastical holdings in, 149 .

Carlisle, 68, 83 , 100, n. 5 , 103, n. 3 , I56, I57, n. 3, I77; tenement of David the Dyer at, I02, n. 3 .

Carlow, 68.

Carmarthen, see Caermarthen.

Carnarvon, 68.

Carter, Adam, 78, n. 5 .

Castle messuages, in boroughs, $103 \mathrm{f}$.

Castle Rising, I7; subject to the knighting and marrying aids, Io f., 59, I93, n. I; free from the marriage incident, I 2; free sale at, 56, n. 6, II 3, I 84 .

Chamberlayn, Edward, I22, n. I.

Channel, the, r29.

Chaors (Cahors), Patrick de, 29, n. I.

Chard, I26, n. I; landgable at, 68; free sale at, I13, I 84 ; free devise at, 132, I37, n. 5, I84; mortgage at, I47.

Charlton Hundred, 20, n. I.

Charmouth, $5^{8 .}$

Chepstow, r49, n. 4 .

Cheshire, 58, n. Io.

Chester, 72, n. 3 ; landgable at, 62, 66 f., 68; at fee-farm, I57, n. 2; customs of, in Domesday, 158, n. 2, 163 ; relief at, I64.

Chesterfield, 57,78, n. 2, I 27, I 83 .

Chichester, bishop of, 38 .

Chippenham, 44, n. I.

Christchurch Twynham, I5.

Cinque Ports, the (Hastings, Romney, Hythe, Dover, and Sandwich; later Winchelsea and Rye also, and sometimes Faversham and Pevensey), I 3 f., I 5, n. 3, I6, I 7, I 8, I 9, 4I, 42, 44, I 28 , I 29, I 53, n. I, I 76, I83, I84, 202.

Citeaux, abbot of, 7 I, n. 2, 78, n. 4, I०9, n. 5 .

Cleves, 195, 196, 208, n. 4.

Clifton, I45, n. I.

Cloyn, 68.

Coke, Sir Edward, 4, 2 ×3.

Colchester, Iro, n. 3 ; fealty at, 46,47 ; landgable at, 68 ; rents simple at, 83 ; rentars at, 90 , n. 4 ; restricted devise at, I39, r 84 .
Colmar, 203.

Cologne, 8 , I 76 , n. 9 , I 80, I 8 I, n. I I , I98, 202, n. I.

Colton, William de, 105, n. 3.

Combe, in Oxfordshire, 27, n. 2.

Congleton, 98; landgable at, 68; chartered by Henry de Lacy, 96, 169; lands and burgages at, 96, n. 2, 98, 169; free sale at, I13, I 84 ; devise at, I32, I37, n. 5, I84.

Conquest, the, 23,67, n. $2, x_{5} 8, \mathrm{r}_{62}, \mathrm{x}_{3}$, I64, 168.

Constance, $18 \mathrm{r}$, n. Io.

Coparcenery, $109 \mathrm{f}$., 179.

Cork, I3, x9, n. 6, 30, n. 4; landgable at, 65,68 ; free sale at, I1 $3,123,184$; free devise at, 135, n. 2, r84; at fee-farm, I56.

Cork, prior of, $3 \circ$, n. 4 .

Cornwall 64, n. 8.

Cösfeld, r94, n. 2, I95, 205.

' Courtesy of England,' 89, I45.

Coventry, 83 , 88, Iо I, n. I.

Crécy, battle of (1346), I7, n. I I.

Cressy, Reginald de, clergyman of Norwich, 25, 27, n. 2.

Cumbe, see Combe.

Curie Seimbres, Alcide, 7, I 75, n. I, 2 II.

Danelaw, the, I9. 64, 165.

Danes, the, $165,166, n$. 1 .

Danish customs, $4 \mathrm{I}$.

Danish kings, the, 22.

Dartmouth, 5०, n. 5; relief at, 20; suit of court at, 58 ; landgable at, $68, \mathbf{1} 66$, n. 2 ; sale prices at, 80 , n. I, 81 ; retained rent at, 86, n. 2 ; divisibility of realty at, 108, n. 2 ; consent to sale at, I 45 , n. I.

Dattenried, 197, 205.

David the Dyer, 102, n. 3.

Davy. A. and R., 139, n. I.

Deal, I4, n. I.

Denbigh, I66; relief at, 20,21, n. I, 59; hawgable at, $63,64,68,7$ I f., 96 , n. I; tenurial customs of, 97 ff., I 7 I, n. 2.

Derby, I I9, 156, 184 .

Derby, Earl of, 73, n. 7 . 
Des Marez, Guillaume, 7, 8, i 78 , n. I, Dunbar, Lord, 32, n. I. $21 \mathrm{I}$.

Desmond, Earl of, 73 , n. I.

De Viris Religiosis, statute, 32, n. 2, 9 I.

Devise, see Free devise; Restricted devise.

Devon, county, i6, n. 6 .

Devon, Earl of, see Redvers.

Dieburg, i 80, n. 8.

Diessenhofen, 207.

Dingolfing, $2 \mathrm{O}_{4} \mathrm{f}$.

Divisibility of burghal realty, $108 \mathrm{ff}$; in Germany, 179 .

Dogett, Richard, 122 , n. 1 .

Domesday Book, 9, 19, n. 5,64 f., I $5^{8-}$ 166.

Domesday era, the, $71,74,15^{8-166,168, ~}$ 173 , n. 2.

Domesday scribes, 162, 174, n. 4 .

Doncaster, $21,47,58,68,157$, n. 2, 186. Donai, 141, n. 2.

Dover, 20, n. I, 33, n. I ; wardship at, 15; forfeiture at, $40 \mathrm{f} ., 42$, I64; rent simple at, 83 ; hen rents at, 87 ; restricted sale at, $117,118,123,184$; borough customs of, in Domesday, I $58,{ }^{6} 6_{3}$.

Dresden, 195 .

Drogheda, 68, I23, 136, I 84 ; charter of $1253,13$.

I) ublin, 13, n. $8,14,15$, n. 3,50, n. 5 , 102, n. $2,167,170$, n. 8,201 , n. 12; wardship) at, 16 ; relief unknown at, 19, n. 6; escheats at, 27, ก. $3,3 \mathbf{1}$, n. I, 32 , n. 2 ; forfeiture at, 40, 4I, 42,43, n. 3 , 44; landgable at, $65 \mathrm{f}$, 68 , $; 6$; rents simple at, 83 ; cum$\min$ rent at, 87, n. 4 ; leases in perpetuity at, so, n. 9 ; maximum limit of burgages at, roo, n. I; free sale at, I $3,123,152$, I 8 ; f free levise at, 133 , 134,135, n. 2,138, n. 1, 143, I 84 ; a Bristollian borough, I $3^{6}, 15^{6}$; dislaerison of heirs at, $\mathrm{s} 4 \mathrm{I}$; at fee-farm, $15 \%$.

l)ublin, archlishop of, 30, n. 4 .

DuCange, riterl, 50, n. 5, 90, n. 4.

l) uderstidt, 205.

Dunheved, 57 , n. $4,68,90$, n. 4 .

Dunning, wealthy burgess of Cambridge, 150.

Dunwich, 13, I7, 120, 141, 184.

Durham, 47,50, n. $5,58,68,71,83$.

East Anglia, $\mathrm{I}_{3} 8, \mathrm{I}_{53}$.

East Grinstead, 48, 58, 68, 96, n. 3 .

East Riding, the, 134 .

East Teignmouth, 48 .

Eckertz, Gottfried, 8.

Edward, 'the Confessor,' king of England $(1042-66), 45,117$, n. 4, I 20 , n. $3,124,125$, n. $2,158,159,160,161$, I62, I64, I68.

Edward I, king of England (1272-1307), 14, 18, 20, n. $5,34,35$, n. I, I 20, 175 , n. I.

Edward II, king of Fingland (1307-27), 105, n. 7 , 133 .

Edward III, king of England $(1327-77)$, I 7, n. I1, 24.

Edward IV, king of England (1461-83), 42.

Egremont, I5.

Eisenach, 201, 202.

Elector Palatine, the, $203, \mathrm{n}$. Io.

Elizabeth, 'the Winter Queen,' daughter of James I of England, wife of Elector Frederick $V$ of the Palatinate, marriage of, $12, n .2$.

Ellis, John, 121.

Ely, bishop of, 49, 87, n. 4, 149, 152, n. 2.

Ennen, Leonard, 8.

lirfurt, 200, n. 3, 204.

Escheat, 24-33; in Normandy, 174 ; in Germany, isis, 195 f., rgg.

Iissex, 64, 157, 11. 3 .

Eton, 93, n. 4 .

Europe, northern and western, 3, I I, 145, 170; northern, 175; feudal, 199.

Euskirchen, 181 .

Ivesham, 68 .

Exchequer, the, 72, 91, 105, n. 3, 125 , I 55,150 .

Exchequer of the Jews, 40, n. 2. 
Exchequer of Normandy, the, I72. $\mid$ Free sale, IIO-II4, 152, I84, 208; in Exeter, 20; relief at, 20, 20, n. 8; fealty Germany, $202 \mathrm{f}$.

at, 47; retrait féodal at, 54, 59; re- Freiburg-im-Breisgau, 179, 181, 196, 197, tained rent at, 86 , n. 2; solar at, Ior, n. I; ruinous tenements at, IOI, n. $\mathrm{I}$.

Exeter, bishop of, 48 , n. 3 .

Exeter, Duke of, I49, n. 2.

Fake, Martin, I45, n. I.

Farnham, 21, 39, 62, n. 2, 155, n. 3.

Fealty, 45-49, 59, 60; in Normandy, I72; in Germany, $180,197 \mathrm{f}$.

Femme covert, rights of the, $144 \mathrm{ff}$.; in Normandy, 173 ; in Germany, 179.

Feudalism, 3, 9, I I, 60, $163,183,186$, I99; feudal incidents affecting burgage tenure, I $1-60$, I 63 f., I 72 f., I 76 , I $80 \mathrm{f} .$, I 83, I85, I93-199.

Firma Burgi, the, ro, 30 , n. 4, 72, 73, 91,

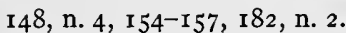

Fitz Alwyn's Assize, Ior, n. I.

Fitz Anthony, Thomas, 30, n. 4 .

Fitz-Stephen, Gilbert, lord of Norton, creates the borough of Dartmouth piecemeal, 20, n. 2, 50, n. 5, 58 .

Flanders, I44, n. I, I82.

Flanders, counts of, 177 .

Flemish cities, the, I 53, n. I, I75, I77, I82, n. 2, 202.

Flemish civic legislation, 183 .

Flers, 172.

Fletcher, John, I 22, n. I.

Ford, abbot of, $5^{8}$, n. 8 .

Forfeiture, $33-45,164,185$; in Germany, I8r, I96 f., 199 .

France, 6, ro, I7, n. II, 97; southern, 7, 175 .

Francis I, king of France ( $155^{-4}$ ), r 72 , n. 8.

Franco-Norman invasion, the, 185 .

Frank almoin, 64 .

Frankfort, i80, I96, n. 7, 204.

Frauenburg, 203.

Frederick, duke of Saxony, I98, n. 5 .

Free Cities, the, 182 , n. 2.

Free devise, I30-135, I52, I63, I $71, \mathrm{I} 84$, 208; in Germany, $206 \mathrm{f}$.

French, the, burn Lymington, I03, n. 3.

French influence on the Cinque Ports, I53, n. I; on Norwich, I70, n. I; on Normandy, after 1203,173, n. 3 .

Friars Minors, the, 79, n. I.

Friedrichshafen, 207.

Frodsham, 68.

Gable, 62 f., 159.

Galtres, forest of, 103, n. I.

Gannoc, 68, 72, 97.

Garz, 200, n. 3 .

Gascon customs, at Denbigh, I 7I, n. 2.

Gehrden, 197, 201, 203.

Gelnhausen, 204, 206, n. 1.

Génestal, R., 6 f., I72, n. 2, 2 I I.

Gengler, H. G., I92.

Germanic law, I78; land law, I15, I25, I72.

Germany, urban tenure in, 3,7 , ro, 85 , I44, n. I, I73, n. 3,174, I78-183, I9I208.

Gernun, W., I32, n. 5 .

Ghent, 7, I 75, I76, I77, I78, n. I.

Gild Merchant, the, at Beverley, I 28, n. 2 ; at Reading, $1_{5}^{6}$, n. 17 .

Gimont, I75, n. 2.

Giraldus Cambrensis, 98 , n. 3 .

Gîte, 59, 72, n. 3, 199 .

Glanvill, Ranulf de, 5, r3o, 2 I4.

Gloucester, 53 f., 93, n. 4, I 21 , n. 2, I64, I67; landgable at, $65,66,68,76$; rents simple at, 83 ; divisibility of burgages, I08, n. 2; free sale at, I I2, I84.

Gloucester, abbot of, 66, n. 5 .

Gloucester, Earl of, issues charters to Cardiff and Tewkesbury, ro8, n. 5, I I 4, I 37 , n. 2.

Gobbers, Joseph, 8.

Goslar, 203, n. 6.

Gowthorpe, manor of, r48, n. 4 .

Grand serjeanty, ro3, n. I.

Great Charter, the, see Magna Charta:

Great Inquiry, the, of $1279,30,63$. 
Grech, 196, 207.

Grenade, 175, n. 2.

Grevenmachern, 200, n. 3 .

Grimsby, 36, 68, I 1 2, n. 2, 157, n. 2, 1 70, n. 8.

Grimston, Agnes de, I34, n. 5 .

Grimston, Richard de, 134, n. 5.

Gross, Charles, 9 .

Grossen-Salze, r94.

Ground rents, see Burgage rents.

Guienne, 98 , n. I, II 3 , n. 5 .

Hachard, Nicholas, I 48 .

Hagenau, I79, I8I, 199 .

Haie du Theil, 172, n. 3 .

Halle, 200 , n. 3 .

Hamburg, 204, 205, n. I8.

Hamm, I80, n. 8, I8I, 200, n. 3 .

Hamo of Valois, 13, n. 8.

Hanover, 195, 204.

Hanse, the, 206.

Hardness, 50, n. 5 .

Hardy, Sir 'T. D., Io, 214.

IIatherlegh, 157 , n. 3 .

Haverfordwest, $22,83, \mathrm{I} 58$, n. I.

Havre, 172 , notes 6 and 8 .

Hawgable, 62 ff., 165 .

Hedon, 120 , n. 4; wardship at, I7; age of majority at, 18, n. 3 ; escheat at, 32,43 , n. 3 ; free devise at, 134,184 .

Heilbronn, 203.

Heimburg, 193, n. 4.

IJenry I, king of England ( $11 \infty-35), 22$, n. 2,76, n. $3,120,159,163,168$.

Henry II, king of England ( $1154-89), 44$, n. 1,67, n. $2,120,155$.

IIenry III, king of England (1216-72), I 6, n. 6, 30, 38, 7I, n. 2,80 , I1. I, I 4 I, I 86, n. I.

Henry IV, king of England (1399-1+13), 25 , n. 6 .

Ifenry $\mathrm{V}^{\prime}$, king of Fngland $\left(1+13^{-22}\right), 20$, n. 2,42 .

Henry VI, king of England ( $1422-61$ ), 57.

Henry VII, king of England ( $1485-1509$ ), 59.
Henry VIII, king of England (I509-47), I57, n. 3 .

Henry I, ' the Fowler,' king of Germany (919-36), I69.

Henry the Carpenter, 49, $15^{2}$, n. 2.

Herbert, William (d. 1570 ), Earl of Pembroke, 32 , n. 2.

Hereford, 103, n. 3, 127,157, n. 3 ; age of majority at, 18, n. 3 ; free from relief, I9; subject to heriot in the Domesday era, 164,199 , n. I; free from heriot in I 28I-82, 22; escheat at, 29, n. I; fealty at, 45, 46; alienation fees, 56 , I 83 , 202; landgable at, 68, 71, I6o f.; rents simple at, 83,90 , n. I; free sale at, $\mathrm{II}_{4}$ f., 184 ; restricted sale at, I24, n. I, 163 ; devise at, 132,140 , n. I; borough customs of, in Domesday, I58, I68; French and English boroughs at, 167,168 .

Herford, I94, n. I I.

Heriot, 22-24, 59, I6 3,164 ; in the Netherlands, 176 ; in Germany, 179 , I80, 193 ff.

Hertford, 64 , 162 .

Hesding, Ernulf de, I6o, n. 4.

Heymer, William, I 22, n. I.

Hildesheim, 203.

Hill, John, I 2, n. 2.

Hock-Day tenure, 167, n. 3 .

Iolborn, I 49 , n. I.

Holderness, 32, n. I.

Holzhagen, 200, n. 3 .

Ifolzminden, $\mathrm{I} 96$.

Ifomage, 49 f., 59; in Normandy, 172 ; in Germany, 180.

Hörde, 194, n. I1.

Iforswade mill, 88, n. 6 .

Ifull, 185 , n. 2; escheat at, 25; a royal borough, II3 I32; free sale at, I13, 184 ; devise at, 132 f., 143 , n. 2,184 .

Hundred Rolls, the (Rotuli IIundredorum), $9,63,150$.

Hundred Years' War, the, Io3, n. 3 .

IIuntingdon, 42, 69, I60, 162 .

Iuntington, Earl of, 149 , n. 4.

Hüssen, 205. 
Husting, Court of (the Hustings), I6, n. 6 , III, n. 2, I 28, n. 2 , I 29, n. 4,130 , n. $2,14 \mathrm{I}$, n. 6.

Hythe, 8 r, 87 , n. 2, ror, n. I.

Iglau, 207, n. 5 .

Inchcoyn, 58 .

Ingolstadt, 195 .

Inistiogue, 69, 96, n. 3, 109, n. 2, I 23 136, I 84 .

Inpenny and outpenny, paid to the borough lord, $57 \mathrm{f}$; to the community, I $27 \mathrm{ff}$.

Interest, rate of, 85 .

Ipswich, 15, n. 3,93 , n. 4; wardship at, I7; age of majority at, I8, n. 3 ; free from relief, 19; escheat at, 24; free from fealty, 45 ; free from homage, 50 , n. I; hawgable at, 64,69 ; rent simple at, 83 ; retained rent at, 86, n. 2 ; hen rents at, 87 ; rose rents at, 88 , n. 6 ; size of a messuage at, I00, n. 5 ; coparcenery at, IIO; sale probably restricted at, I20 f., I 24, I84; devise at, I3 8 f., I 45, I 84 .

Ireland, 30, n. 4, 39, I99, n. 2, 200; the king's escheator for, 25 , n. 4, 3r, n. I; the justiciary of, $57, \mathrm{n} .4$.

Ireland, boroughs of, $9,52,60,93,95$, $96,97,98$, I35, I7 1, 199, n. 3 ; wardship in, I6; relief unknown in, 19; fall into two groups, 123, 136, 169; differ as to restriction on sale, I25, n. 2, I 52; mortgage in, 146 ; Bretollian boroughs, I67, I68, I70, I 84 .

Irish, the, 98 .

Isaac, Jew of York, singular death of, 26, n. 5 .

Isabel, daughter of Reginald de Cressy, 25.

James I, king of England ( $\left.160_{3}-25\right)$, r2, n. 2.

Jerichow, 207.

Jewry, the, I04, n. I.

Jews, the, 26 f., 36 , n. 7,39 f., 9r, n. 2 , I 3 , n. 9 .

John, clerk of Shefford, $43, n$. I.
John, king of England (1 $199-1216), 1_{3}$,

n. I, I4, I5, n. $3,52,65, I_{3}$.

John of Gaunt, 28, n. 2.

John of Yarmouth, I 27, n. I.

Kahla, I97, I98.

Kenfig, 47, n. 5, 8I, 86, n. 2, 93, n. 4, I47, n. 3 .

Kent, 4r.

Keutgen, Friedrich, 7, 8, I78, n. I, I9I, n. 2, 212.

Kidderminster, I9, 22.

Kiel, 202, 206.

Kilkenny, I3, I6, n. 4, I09, n. 2.

Kingsthorpe, 54, n. 3, I19, n. 3, 122, n. I, I 26 , n. I, I28, n. 4,142 , n. 4 , 147, n. 6 , I 74, n. 3 .

Kingston-upon-Hull, see Hull.

Kingston-on-Thames, 83,93 , n. 4, ${ }_{5} 6$.

Kinsale, 73.

Kin's retrait, see Retrait lignager.

Königsberg, 200, n. 3 .

Lacy, Henry de, Earl of Lincoln, charters Congleton ( 1272$), 96,113$, n. 2, г 32, n. 2, ז69; founds Denbigh (1290), 20, n. 5, 52, 64, 97 f., I66.

Lacy, Roger de, 78 , n. 2.

Lancashire boroughs, the, I2O, I 24.

Lancaster, Duke of, ro4, n. I.

Lancaster, Earl of, lord of the borough of Liverpool, 73.

Lancaster, Henry, Earl of, ro4, n. r.

Landgable, 64-79, I59-I62, I65 f., I 85 .

Landsberg, 202, n. I.

Landshut, 208.

Landtoll Penny, the, 67, n. 5 .

Launceston, 24, n. 2.

Leasing, 89 f.; in the Netherlands, 176 . Lechnich, 201, 203.

Leeds, 99 ; alienation fees at, 56 ; landgable at, 69 ; capital messuage at, 78 ; leasing at, 89,90, n. 4 ; arable plots included in the messuages, $96, \mathrm{n} . \mathrm{I}$; free sale at, I $12, \mathrm{I} 84$.

Leek, 69 .

Legras, Henri, 6 f., 2 I 2. 
Leicester, 50, n. 5, 162; relief at, 20, 33, n. I, 59; escheats at, 25, 28; forfeiture at, 42 ; bridge-silver and gavel-pence at, 62, n. 2; landgable at, 69 ; rents in kind at, 72 , n. 2 ; hen rents at, 72, n. 2 , 78, n. $6,87,173$, n. 7,178, n. 2 ; sale price at, 81 ; rent simple at, 83 ; free sale at, I1 2, 184; has grant of the farm in fee, 156 .

Leo, a Jew, 26, n. 3 .

Lewes, 69, 160, n. 5 .

Liber Custumarum, 126, 2 I 6.

Liber Winton', 9, 65, 71, 92, n. 2, I 59 .

Lichfield, 23, 69.

Lidiard, Johanna de, 134, n. 2.

Lidiard, John de, 134, n. 2.

Limerick, 13 ; has the customs of Dublin, 13, n. 8 , г9, n. 6 , I13, I23, 13.5. ก. 2; military service at, 52, 59; landgable at, 69; free sale at, $113,123,184$; devise at, 135, n. 2,138, n. 1,184 ; at feefarm ( 1197$),{ }_{5} 6$.

Lincoln, 162 ; Jews at, 40, n. 2; landgable at, 67, 69, 16 1, 166, г68; retrait lignager at, $120,163,184$; at fee-farm (1130), 155 .

Lincoln, Earl of, see Lacy.

Lincolnshire men, settle Denbigh, 64, 97.

Lindsay, barony of, 24 , n. 5 .

Lippstadt, r 96 .

Liskeard, 25.

Lisle, Viscount, I49, n. 4 .

Littleton, Sir Thomas, 5, 213.

Liverpool 91, n. 2, 104, n. I; escheat at, 25; gîle at, 59,72, n. 3 ; landgable at, 69,75, n. 2 ; intermittent Firma Burgi of, 73 , r 56 f.; rents simple at, 83 ; dimensions of messuages at, 100, n. 5 ; divisilsility of burgages, 75 , n. $2, \operatorname{10} 8$.

Llandowery. $69,71,96$, n. 3 .

Lods et venles, see Alienation fees.

London, 10, n. 6, 38, 70, 01, 12. 2, 9.3, n. 4 , $128, \mathrm{n} .2,160,177$; private dealing in wardship and marriage at, I8, n. 2; escheats at, 24, n. 5, 27, 30, 35, 44; royal wine-cellar at, 30 ; forfeiture at, $35,3^{6}, 43$; tenurial heterogeneity and its consequences, 37 ; fealty at, 47 ; landgable at, 69,76, n. $1,165,182$; capital messuages at, 79; sale simple at, 80,81 ; rents simple at, 83 ; retained rents at, 86, n. 2 ; condiment rents at, 87 , notes 4 and 5 ; spur rents at, 88 ; rose rents at, 88; leasing for short periods, $89 \mathrm{f}$.; dimensions and values of messuages, 10,101 ; tenure in the messuages dependent on the Tower, r04, n. I; the waste given to the burgesses, I05; divisibility of realty at, 108, I 79, n. 5 ; appeals from the Hustings, II I, n. 2; free sale at, 112, I 84 ; the disappearance of the kin's preëmption, I $25 \mathrm{f}$., $152 \mathrm{f}$.; land transfers by indenture at, 129, n. 4 ; free devise at, 130 , 131, 142, 184; peculiar limitation upon freedom of devise, I4I, 145, 207, n. II; holdings of the bishop of Ely in, 149.

London, bishop of, $33,43,56,128$, n. 4 , 1 29, n. 2.

Long Parliament, the, 186.

Lord's retrait, the, see Retrait féodal.

Lostwithiel, 69.

Louviers, 173 , n. 6.

Low Countries, the, see Netherlands.

Lübeck, 179, 203, n. 6, 205, n. 18.

Lucerne, 208.

Ludlow, 42, 43, 44, 69, 7 r.

Lüneburg, 194, n. I r.

Lünen, I94, n, 1 r.

Lusignans, the, 12 , n. 2.

Lymington, ro3, n. 3 .

Lynn Regis (Lynn, King's Lynn, Bishop's Lynn), 20, n. I, 33, n. 1, 79, n. 3, 84, I $12,133,184$.

Macaulay, 98, n. 3 .

Madox, T., 10, 156, 215.

Magdleburg, 202, n. I.

Magna Charta, 4.

Maitland, F. W., 6, 30, 62, 152, 158 .

Maldon, I28, 129, n. 2; escheat at, 33 ; forfeiture at, 39, 43; fractional registration fee at, $5^{6}, 57$, n. 5,183 ; hawgable at, 64 ; rent simple at, 84 ; joint tenancy at, i ro, n. 3 . 
Manchester, 15, n. 2; relief at, 21, 59, Naumburg, 195, 205, 206.

I 7 I, n. 2; heriot at, 22, 23, n. 6, 59, Netherlands, the, urban tenure in, 3, 7, I 7 I, n. 2, I93; fealty at, 48, 50, 59; homage at, 49, 5०, 59; alienation fees at, 55,57 ; suit of court at, $5^{8}$; landgable at, 69 ; rents simple at, 84 ; right to lease at, 89 ; restricted sale at, II9, I84; restricted devise at, 137,172 , n. I, 184 .

Mannheim, in Pennsylvania, 88, n. 7 .

Manno Brito, 16o, n. 4 .

Marlborough, I8, n. 2, 44, n. I.

Marriage, I $2-15,59,164,170$; in Normandy, I70; in Germany, I80, 193.

Marshal, William (d. 1219), Earl of Pembroke, charters Kilkenny, I6, n. 4 .

Marshal, William (d. I 23I). Earl of Pembroke, son of the preceding, granted tenements in London, 38,80 , n. $\mathbf{I}$.

Masscrief, Robert le, 43, n. I.

Maurer, G. L. von, I92.

Medebach, I8I, I94, 201.

Melcombe Regis, 69, I4I, n. 4, I84.

Mercia, Alderman of, 166.

Merewether, H. A., 6, 2 II.

Merton College, 63, n. 3 .

Merton, prior of, 157, n. 3 .

Middlewich, $5^{8}$, n. 10.

Military service, $5^{\text {I }}$ f., 58,59 .

Minden, 197, n. I.

Mobility of burghal realty, I08-153; in Germany, 20I-208.

Monmouth, I49, n. 4 .

Monmouth, prior of, I49, n. 4 .

Montacute, 69 , 1०3, n. 2.

Montfort, Simon de, 62, n. 2.

Montgomery, 36, n. 7, 97, n. 2.

Montivilliers, I 72 f., I74, n. I.

Morpeth, 69, 84, 96, n. 1, г 21, 184.

Mortain, Count of, I59, n. 7 , I6I, n. 7 .

Mortgage, $146 \mathrm{ff}$.; in Germany, 178,180 .

Munich, 193, 202, n. I, 205.

Municipal Corporations Act, the (1835), I86.

Münster, I80, 200, n. 3 .

Münster, bishop of, I94, n. 2 .

Murder fine, the, 67 , n. 2. 10, I73, n. 3, I75-I 78, I82, I83, 200.

Neuburg, 205 .

Newbury, ${ }_{5} 6$.

Newcastle, 14, n. 5, 16; heriot denied at, 22; forfeiture at, 36 ; landgable at, 69 ; rents simple at, 84 ; commutation of cummin rents at, 88 , n. 1 ; extension of its boundaries, I03, n. 3 ; restricted sale at, I20, I 24, I 84 ; restricted devise at, 139,184 ; customal of, 163 .

Newport, 69.

New Ross, 39, 69, 84 .

New Town, 58, n. 4 .

Nicholas of Norwich, $127, n .1$.

Norfolk Feet of Fines, I 29, n. 4 .

Norman customs, 52, I68, I 7 I, I 74, n. 7, I84, n. 2.

Normandy, burgage tenure in, $3,6 \mathrm{f}$., I 29, I 36, I68, I70, ก. 7, I $72-175,177$, I 82 f., 200,201, n. 2 ; feudal tenure in, I7, n. 9 .

Normans, the, 43 f., I63.

Northampton, 60, II9, 162, n. 6; relief at, 21 ; escheats at, 26; retrait féodal at, 52 f., 54; 'sellings' at, 54 f., 6o, I 28; landgable at, 69, 160; leasing at, 90 , n. 4; charter of $1200,113 \mathrm{f}$; the kin's retrait at, I 5 ff., I 35 , I 74, n. 6 , I84, 205, n. 16, 206; fractional alienation fee at, 128, 129, 183; at fee-farm, I55; French borough at, 160; English borough at, 160 .

Northumberland, Earl of, 48 .

North Wales, 52, 63, 64; the English garrison boroughs of, $175, n$. 1 .

Norton, John, $\mathbf{I} 2 \mathbf{I}$.

Norton, lord of, see Fitz-Stephen.

Norwich, 9I, n. 2, 147, n. 5; escheat at, $25 \mathrm{f}$; f forfeiture at, $34 \mathrm{f} ., 43$; retrait féodal at, 53, 59; landgable at, 66, 69, $79, \mathrm{n} . \mathrm{I}, \mathrm{I} 6 \mathrm{I}$; burgages in the fee of the castle, 73; fluidity of reality at, 80 , n. I; sale prices at, $8 \mathbf{I}$; rent simple at, 84; leasing at, 89, n. 7; arable land pertaining to a messuage, 95, n. 1 ; dimensions of messuages, 100, n. 5 ; 
lands in the fee of the castle granted to the citizens, ro4; the waste at, ro5; inpenny and outpenny at, 127, 169, I 83; sale at, I29, n. 4, I38, I43, I84; devise at, 138,184 ; rights of the femme covert, 145; French influence upon, r $70, \mathrm{n}$. I.

Norwich, Bishop of, $20, \mathrm{n}$. I.

Nottingham, r 7,93 , n. 4 ; hen rents at, 87 , n. 2 ; charter of $1200,113 \mathrm{f}$; the kin's retrait at, 118,184 ; devise at, I 34 f., I 84; landgable at, r6o; meaning of mansio at, 162 , n. 1 ; French borough at, 168; English borough at, I68.

Okehampton, 69 .

Old Black Book, the, at Plymouth, 32, n. 2.

Oldenholm, meadow at Ipswich, 88, n. 6 . Old Ross, 25.

Original rents, see Burgage rents.

Origins, jungle of, 4 .

Oswestry, 23, 69, 71, 96, n. 3, 103, n. I, I 71, n. 2.

Ouhtred, John, 79, n. I, I 48 f., I50.

Ouse, the, 48,60 .

Overton, 113, n. 5, 132, 175, n. 1, 185, n. 2 .

Oxford, 20, n. 1; escheats at, 24, n. 5, 27; forfeiture at, 36, 38 ; landyable at, 66, 69,76, n. 3,165, n. 5 ; rents simple at, 84; retained rent at, 86 , n. 2 ; spur rents at, 88 ; dimensions of messuages at, 100, n. 5 ; leave to tunnel bencath the streets at, 105; iree sale at, 112 , Is 4 ; free devise at, 130 , n. 2, I 42 , I 84 ; financial customs at, I60; mural mansiones, 160, n. 6.

Oxforlshire, 122 , n. 1 .

Padberg, 106, 200, notes 1 and 3.

Pagand, Ilaurice, of. n. I, 99, n. 2.

Parchim, 304, n. I 1.

Parliament, represcntation in, 157, n. 3 .

Passall, 197, 20.4, 206, n. I.

Patent Rolls, the, 9, 67, 150, 214.

Pemloroke, 21, 114, 154.
Pembroke, Earl of, see Marshal; Valence; Herbert.

Pesth, 204, 207.

Peter of Valongies (Valognes), I63.

Petersfield, 73, 10, n. 5 .

Pevensey, 69, I59, n. 7, 160, n. 2.

Pfullendorf, 196, n. 4.

Philip, king of the Romans, Holy Roman emperor ( I I 98-i 208), I99, n. I.

Picot, sheriff, I64, n. 7 .

Pirot, Sir Ralph, 28, n. 3.

Plantagenets, the, I 20.

Plymouth, 32, n. 2, 84, I56.

Plympton, I6, n. 6, 84, I०3, n. 2, I66, n. 2.

Pollock, Sir F., 6, 1 26, n. I, 2 I 1 .

Pontefract, 78; alienation fees at, 56; landgable at, 69, I 70, n. 8; collection of the landgable, 72, n. 4 ; divisibility of realty at, 108, n. 5 ; free sale at, I I 2 , 184; livery of seisin through the lord, 126 , n. 1 ; the farm of, 155, n. 3 ; has the customs of Grimsby, i 70, n. 8.

Pontorson, I74, n. I.

Portsea, 72.

Portsmouth, $\mathbf{7} 73$, n. 7 ; relief at, $2 \mathbf{1}$; landgable at, 69; pepper rents at, 72 ; restricted sale at, II $7,123 \mathrm{f}, 18.4$; restricted devise at, 141,184 ; at feefarm, ${ }_{5} 6$.

Prenzlau, 194, 200, n. 3.

Preston, I2; 'sellings' at, 55, 57; inpenny and outpenny, $57,127,183,201$, n. 8 ; nature of the burgage at, 93 , n. 3 ; twelve-foot burgage limit at, 93 , n. 3 , 109, 173 , n. 8; restricted sile at, 1.4, 184 ; at fee-farm, 155 .

Quedlinlsurg, 204, 206, n. s.

Quenerton, John, 122, n. I.

Quenerton, Robert, i22, n. I.

Quid Eimplores, statute (1200), 185.

Raclolfzell, 205.

Raleghl, John of, 137, n. 1.

Rappoltstein, 198.

Rathcool, 19, 169, n. 2; landgable at, 70; each house has four acres of land, 96 , 
n. 3 ; free sale at, $113,123,184$; free devise at, 135, n. 2,184 .

Rathmore, 70, 96, n. 3 .

Ratisbon, 179, 197, 205.

Ravenser, 143, n. 2.

Ravensrod, 105, n. 3 .

Reading, I 2, n. 2, 21, 22, 8I, I45, n. 6, I 56.

Redvers, Baldwin de (d. 1245), Earl of Devon, I03, n. 2.

Redvers, Baldwin de (b. I235, d. I 263), Earl of Devon, son of the preceding, I 5 , n. I.

Reformation, the, 150 .

Reform Bill, the, of $1832,74,99$, IOI, n. I, I02, n. 3, I 86.

Reginald, son of Robert le Blund, 26.

Relief, I8-2 I, 59, I64; in Normandy, I 72, 174 ; in the Netherlands, 176 ; in Germany, I 79, I80, 193 .

Renaissance, the, 7I, n. 3 .

Rendon, 57, n. 4.

Rents and sales of messuages, 80-91; hen rents, 87, I 73, I 78, n. 2 , I 80,200 , n. 2 ; condiment rents, $87 \mathrm{f}$., I 78 , n. 2; glove rents, 88 ; spur rents, 88 ; rose rents, $80,88 \mathrm{f}$; rents simple, 82 84 ; retained rents, $85 \mathrm{f}$; ; consent to sale, 86, n. 2, 144 f.

Restricted devise, I35-I44, I 52, 163, I84; in Normandy, 174, 182; in Germany, $207 \mathrm{f}$.

Restricted sale, I 14-1 26, I $5^{2}$ f., I63, I70, I84; in Normandy, 173, I74, 182; in the Netherlands, I77; in Germany, I 78, I 79, I8I, $204 \mathrm{ff}$.

Retrait féodal, 52 ff., 59 f.; in the Netherlands, 177 ; in Germany, $178,179,182$, I98 f.

Retrait lignager, I I 4-I 26, I 52 f., I63, I 70, I84; in Normandy, 173, 174, 182; in the Netherlands, I77; in Germany, I 78, I 79, г 8 г, $204 \mathrm{ff}$.

Rheda, I96, n. 7 .

Rhine, the, 183 .

Rhine towns, 85,91 .

Rhine valley, upper, I 8 , n. 3 .

Rhuddlan, 90 , n. 4 ; free sale at, I I 3,172 , n. I, I 84 ; devise at, I40, I44, n. I, I 84 .
Richmond, 25, I0I, n. I, 108, n. 2.

Richmond, John, Earl of, 25, n. 7 .

Robert le Blund, 25.

Robert le Vilen, 20, n. 2.

Robert of Scarborough, I48.

Robert the Leech, 50, n. 5 .

Rochester, 42, 43, 44, 156.

Roman Empire, the, 77, n. I.

Roman fever, $16_{5}$, n. 1 .

Roman fiction, 72.

Roman law, I74, n. 3 .

Romney, I9, 45, I18, I 28, I83, I84.

Rosenthal, Eduard, 7 .

Rospont, see Ross.

Ross, 25, 8I, 96, n. 3 .

Rotenburg, 203.

Rottweil, 205.

Rouen, I 73, 174.

Ruthin, 21 , n. I, I86, n. 3 .

Ruyton, 70, 71, 96, n. 3 .

Rye, 93, n. 4; forfeiture at, 40, 42; customal of, 4I; landgable at, 70; sale prices at, $8 \mathrm{I}$; rent simple at, 84 ; retained rents at, 86, n. 2 ; vacant land at, 105, n. 2; divisibility of realty, I08, n. 2 .

Saffelaere, I 76, n. 9 .

St. Augustine's church, at Norwich, 34 .

St. Botolph's, prior of, 47 , notes 6,7 .

St. Ives, 84 .

St. John's day, 88.

St. Lezier, I73, n. 8.

St. Mary's Abbey, 87, n. 4.

St. Olave's church, at Norwich, 34 .

St. Paul's, Ioo.

St. Peter, hospital of, at York, 76, n. 3 .

St. Swithin's, at Winchester, prior of, 47 , n. 8, I98, n. 2.

Sale, see Free sale; Restricted sale; Rents and sales of messuages.

Salford, 22, 55, 70, I I9, I37, I 7 I, n. 2, I 84 .

Salisbury, 70,75 , n. 2, I 26, n. I, 147 .

Salisbury, bishop of, 147 .

Salzwedel, I94, n. I I.

Sampson, Abbot, I I 7, 125 , n. 2.

Sandwich, I4; wardship at, I7; forfeiture at, 40; the waste considered 
communal property, 106, n. 1 ; inpenny and outpenny at, 127,183 ; fee to town-clerk, $127 \mathrm{f}$.

Saxony, 198, n. 5 .

Scandinavian lands, the, 183 , n. 2 .

Scarborough, 78 , 91, n. 2 ; gable at, 62 , 70,71 ; unique custom of, as to burgage rents, $7 \mathrm{r}, 76, \mathrm{n} .3$, 109; capital messuages at, 79 , n. 1 ; rents simple at, 84 ; leasing at, 90; nature of the burgage at, 93 , n. 4 ; extension of the borough bounds, 103, n. 3 ; the waste at, 105, n. 6; free devise at, 133, 184; accumulation of burgages at, 148,150 ; at fee-farm (1 253), 156 .

Schulte, Aloys, 192, n. 2.

Schwaney, 195, n. 1, 201, 206, n. 1.

Schwerin, 196.

Scotland, 71 .

Scots, the, 91, n. 2.

Sege, Richard de, 145, n. 1.

Sellings, see Alienation Fees.

Selz, 197.

Shaftesbury, 57, 70, 84 .

Sharpness, 41 .

Shefford, 43, 44.

Shephard, Robert, 12, n. 2.

Shrewsbury, 184 ; the marriage incident at, 15, n. 3, 164, 170, n. 3; landgable at, 70,161 ; devise at, $140,142, n .4$; heriot at, 164; the Norman bourg at, 167.

Sigmund, luke of Saxony, 198, n. 5.

Silverun, datughter of Robert le Vilen, gives a release from reliefs and homages, 20, n. 2, 50, n. 5 .

Soest, 170, 180, notes 6 and 8. 201.

Solomiate. 175, n. 2.

Southampton, 93. n. 4, 101, n. 1; escheats at, 20; rent simple at, 84 ; hen rents at, 87, n. 2, 178, n. 2 ; glose and pepper rents att, s8, n. 4 ; the waste at. 105. n. 6; divisibility of realty all, 108, II. 2 ; devise at, 141,184 ; mortgage at, $1 .+7, \mathrm{n} . \mathrm{s}$; accumulation of burgagers at, 145,140

Southstoke, 85 .

Southwark, 20, 157, n. 3 .

Siothwick, $; 2$.
Spires, 179, 199, n. 1, 202, 203, n. 10, 207.

Stablegate, r 33, n. 5 .

Stade, 195, 202, 204.

Stafford, 162.

Stafford, Letia de, 134, n. 5 .

Stafford, Thomas de, 134 , n. 5 .

Staffordshire, 87 .

Stargard, 200, n. 3 .

Statute of Wills, the (1540), 186.

Stendal, r 94, n. $1 x$.

Stephens, A. J., 6, 211.

Stockport, 137; relief at, 21, 171, n. 2; heriot at, 22, 23, n. 6, 171, n. 2; fealty at, 49, 50; homage at, 49, 50; fixed alienation fees at, 55 ; suit of court at, 58; landgable at, 70 ; restricted sale at, 119, 184; restricted devise at, 137 , 18.4 .

Stokecurcy, 48, 104, n. I.

Stralsund, 202, $206 \mathrm{f}$.

Strasburg, 182, n. 1, 197, 198, 199. n. 1, $201,204$.

Suit of court, 58,60 .

Sussex, $5^{8}$, n. 9,96, n. 3 .

Sussex. Earl of, see Albini.

Suwerk, see Southwark.

Swansea, 70.

Swarland, 14, n. 5.

Swenin, Katherine, 207, n. 11.

Swords, 7o.

Taillor, Willi:ım, 122, n. 1.

Tatunton, ;0, 160, n. 3 .

Tettenhall Regis, 54, n. 3 .

Teutonic lands, 183 .

Trutons, 183.

Tewkesbury, 12; free from relief. 10; free from heriot, 22; fealty at, $4^{(2)}$ alienation fers at, .5; lamblgable at, 70; restricted sale at, $114,115.124$, 184; restricted devise :1t, 137, $184 ;$ mortgalge att. $14^{0}$.

Thame, 20, n. 2.

Thames, the, 100,183 .

Thornlsury, 81, 108, n. 2.

Thurkelby, Robert of. 43, n. 1 .

Torskey, if).3; (ustomal of, 40, It. j. 
Tower of London, the, 35, n. 2, I04, n. I. Trent, the, 48, 60, 105, n. 7 .

Troppau, 207.

Tudor sickle, the, I5o.

Tutbury, I5, n. 2, 23, 87.

Überlingen, $205,207$.

Ulm, 200, notes 2 and 3,207 , n. 5, 208.

Ulwi of Hatfield, 163 .

Ülzen, I94, 204.

Upper Rhine, towns of the, 178 .

Uttoxeter, $23,70,73$, n. 7,87, r64, n. I.

Valence, Aymer de (d. 1324), Earl of Pembroke, charters Wexford (I3I7), 93 , n. 3, 123, n. 2.

Verden, 194, 205, 206, n. I.

Verneuil, I70, n. 7, I74, n. I.

Vesci, William de, I22, n. 2.

Vienna, I8I; free from the marriage incident, 193.

Vinus le Longe, 36 , n. 3 .

Wake, John, Lord, 57 .

Wales, 52, 199, n. 2.

Wallingford, 62; landgable at, 70, 160, notes $I$ and 2 ; retained rent at, 86 , n. 2 ; borough customs of, in Domesday, 158 .

Walsall, 54, 70, I 26, n. I.

Walter of Norwich, I $27, n$. I.

Warburg, 200, n. I.

Wardship, $15^{-18}$, 59; in Germany, 180 , I93.

Warin, son of Gerald, 43, n. I.

Wars of the Roses, 43.

Waste, the, $104 \mathrm{ff}$.

Waterford, 5o, n. 5; wardship at, I6, n. 4; no relief at, I9, n. 6; has the customs of Dublin and Bristol, 19, n. $6,123,135$, n. 2,170 , n. 8 ; landgable at, $65,70,170, n .8$; free sale at, I I3, I 23, I 84 ; free devise at, I35, n. 2, I $38, n$. I, I84; disherison in anger at, I 41 , n. 8; accumulation of burgages at, 148 .

Waynflete, William of, bishop of Winchester, 39 , n. 3 .
Weare, 108, n. 2.

Wearmouth, 114, n. 6, I20, n. I, I84.

Weichbild, see Germany, urban tenure in.

Weida, 207 .

Wells, 50, n. 5, 70, 86, n. 2, IOI, n. I, I45,

n. $\mathbf{r}$.

Welsh, the, 97.

Welsh border, the, 164,173 , n. 2.

Welsh boroughs, the, I99, n. 3 .

Welsh marches, the, 95, 96, I I4, I67.

Welsh towns, 136 .

Wenceslaus, Holy Roman emperor ( $1378-$ I400), 203 , n. 6.

Werl, 194.

Wernigerode, 194.

Wesel, I96.

Westgate, aldermanry of, 36 .

Westmelne, 8r, 84 .

Westminster, 28, n. 3,36 , n. I, I I I, n. 2, I 29, n. 4 .

Westminster, Marquis of, 157, n. 2.

Weston, John de, 36, n. 6.

West Teignmouth, 48 , n. 3 .

Wetzlar, I8o, I8r, n. I I.

Wexford, 13, 7o, 93, n. 3, 123, I36.

Weymouth, 93, n. 4; fealty at, 47,198 , n. 2 ; landgable at, 70,72 , n. 4 ; restricted devise at, I4I, 184 .

Whitby, I3; fealty at, 47 ; retrait féodal at, 54, 59, I79, n. 15; alienation fees at, 55; landgable at, 70; rent simple at, 84 .

William I, the Conqueror, king of England $(1066-87)$, I 20, I58, I59, I6 I, I64, I68.

William II, ' the Red' (Rufus), king of England (1087-1100), 26, 164.

Winchelsea, 70 .

Winchester, 47, n. 8,9 I, n. 2 , 93, n. 4 , I5०, I67, I68; escheat at, 29, 30; Liber Winton', 65, 7 1, 159; landgable at, 65, 70, 7I, 76, 77, I59, I6o; rents simple at, 84 ; leasing at, 89 ; divisibility of realty at, 110 , n. 3 ; free sale at, I 2, I 84 ; devise at, I39, n. 7 .

Winchester, bishop of, I4I, n. 2, I50, n. 4 . 
Windsor, 26.

Winter Queen, the, see Elizabeth, daughter of King James I.

Wirzburg, see Würzburg.

Wismar, 202, n. 3, 205.

Wodehall, 14, n. 5 .

Woodstock, 84; landgable at, 70; restricted sale at, 122 f., 126 , n. I, 184 ; at fee-farm (1453), 156 .

Wool Quay, the, 108, n. 3 .

Worcester, 84,86, n. 2 , 149 , n. 4 .

Worms, I 79, I 89, n. 1, 203.

Würzburg, 7, 198, 206, n. 1 .

Yarmouth, I8, n. 3; landgable at, 70; restricted devise at, 138, n. $3,139,184$. York, 103, n. 1, 134, 158, n. 2, 162; free from relief, 19; singular death of Isaac the Jew at, 26 , n. 5 ; escheated mill at, 26, n. 5; forfeiture at, 30 ; hawgable at, $63,70,76$, n. 3,161 ; rents simple at, 84 ; glove and pepper rents at, 88 , n. 4 ; ruinous messuages at, 101, n. I; the kin's retrait at, 120 , 184 ; free devise at, 131 f., 139 , n. 7 . 184 ; wasted by the Danes, 166 n. I. Youghal, 70.

Ypres, 141, n. 2.

Wycombe, 78 , n. 5 ; rent simple at, 84 ; retained rent at, 86, n. 2 ; free sale at, 113, 184; free devise at, 132, 184. Zuzenhausen, 203. 

Date Due

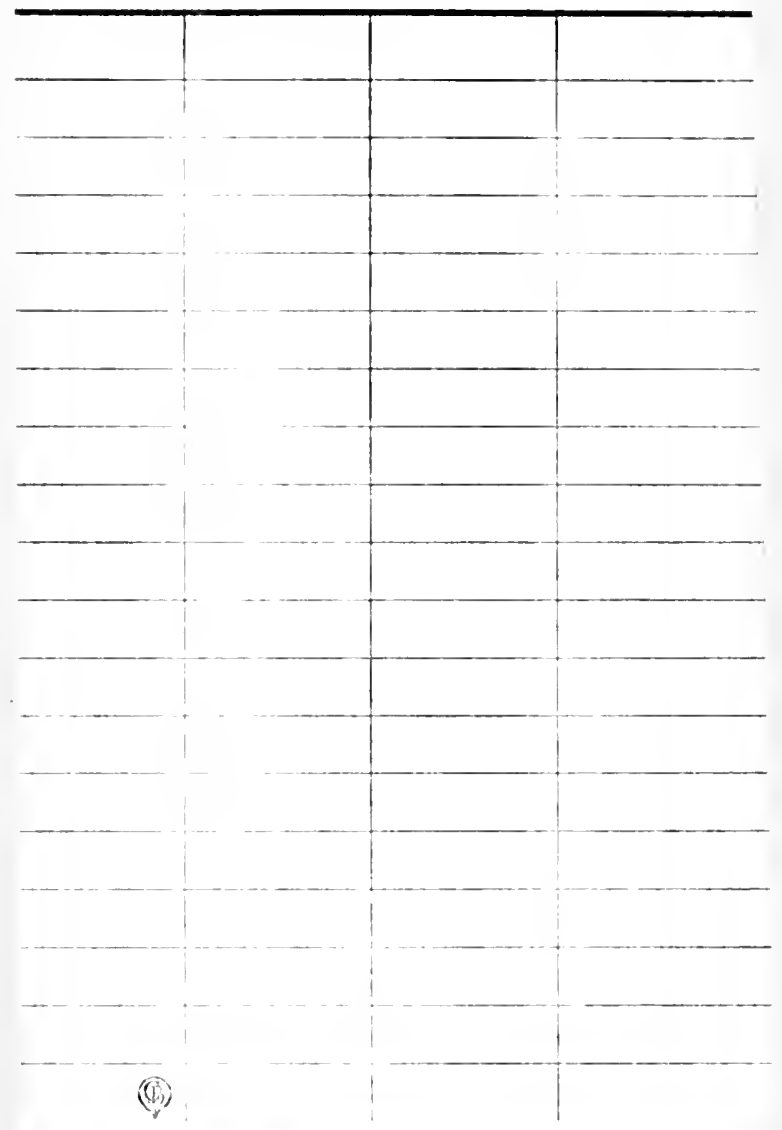


Hemmeon, M.W.

Burgage tenure in mediaeval inglend. 


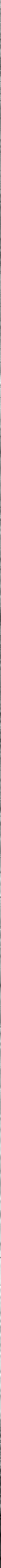

